\title{
Dietary folates in human nutrition : analysis, intake, bioavailability and association with colorectal cancer
}

Citation for published version (APA):

Konings, E. J. M. (2001). Dietary folates in human nutrition : analysis, intake, bioavailability and association with colorectal cancer. [Doctoral Thesis, Maastricht University]. Maastricht University. https://doi.org/10.26481/dis.20010914ek

Document status and date:

Published: 01/01/2001

DOI:

10.26481/dis.20010914ek

Document Version:

Publisher's PDF, also known as Version of record

\section{Please check the document version of this publication:}

- A submitted manuscript is the version of the article upon submission and before peer-review. There can be important differences between the submitted version and the official published version of record.

People interested in the research are advised to contact the author for the final version of the publication, or visit the DOI to the publisher's website.

- The final author version and the galley proof are versions of the publication after peer review.

- The final published version features the final layout of the paper including the volume, issue and page numbers.

Link to publication

\footnotetext{
General rights rights.

- You may freely distribute the URL identifying the publication in the public portal. please follow below link for the End User Agreement:

www.umlib.nl/taverne-license

Take down policy

If you believe that this document breaches copyright please contact us at:

repository@maastrichtuniversity.nl

providing details and we will investigate your claim.
}

Copyright and moral rights for the publications made accessible in the public portal are retained by the authors and/or other copyright owners and it is a condition of accessing publications that users recognise and abide by the legal requirements associated with these

- Users may download and print one copy of any publication from the public portal for the purpose of private study or research.

- You may not further distribute the material or use it for any profit-making activity or commercial gain

If the publication is distributed under the terms of Article $25 \mathrm{fa}$ of the Dutch Copyright Act, indicated by the "Taverne" license above, 


\section{DIETARY FOLATES IN HUMAN NUTRITION analysis, intake, bioavailability and association with colorectal cancer}

Erik Johannes Maria Konings 
The research described in this thesis was executed within the Inspectorate for Health Protection and Veterinary Public Health, and Nutrition and Toxicology Research Institute Maastricht (NUTRIM).

Additional financial research support was obtained from the NEVO Foundation and Unilever Health Institute.

For the publication of the thesis, financial support by the Inspectorate for Health Protection and Veterinary Public Health, and NUTRIM is gratefully acknowledged.

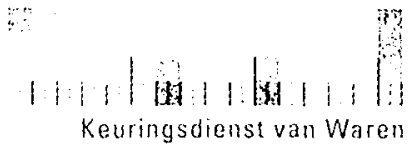

\section{itufin}

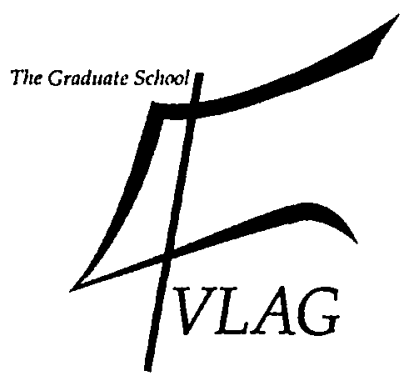

The study presented in this thesis was performed at the Nutrition and Toxicology Research Institute Maastricht (NUTRIM) which participates in the Graduate School VLAG (Food Technology, Agrobiotechnology, Nutrition and Health Sciences), accredited by the Royal Netherlands Academy of Arts and Sciences.

Picture cover design printed with permission of Life Sciences Research Office, Bethesda, USA

Printing: Datawyse Universitaire Pers Maastricht

(c) Erik J.M. Konings, Maastricht 2001

ISBN 90-9014933-3 


\section{DIETARY FOLATES IN HUMAN NUTRITION analysis, intake, bioavailability and association with colorectal cancer}

\section{PROEFSCHRIFT}

ter verkrijging van de graad van doctor aan de Universiteit Maastricht,

op gezag van de Rector Magnificus, Prof. dr. A.C. Nieuwenhuijzen Kruseman volgens het besluit van het College van Decanen, in het openbaar te verdedigen op vrijdag 14 september 2001 om 14.00 uur

door

Erik Johannes Maria Konings 


\section{Promotoren}

Prof. dr. ir. W.H.M. Saris

Prof. dr. ir. P.A. van den Brandt

\section{Beoordelingscommissie}

Prof. dr. P.B. Soeters (voorzitter)

Prof. dr. ir. F.J. Kok (Wageningen Universiteit)

Prof. dr. P.W.J. Peters (Universiteit Utrecht)

Prof. dr. R.W. Stockbrügger

Dr. C. Vermeer 


\section{Contents}

Page

1. General introduction

2. A validated liquid chromatographic method for determining folates in vegetables, milk powder, liver, and flour

3. Folate intake of the Dutch population according to newly established liquid chromatography data for foods

4. Bioavailability of different types of folate in healthy ileostomy volunteers

5. Intake of dietary folate vitamers and risk of colon and rectal cancer. Results from the Netherlands Cohort Study

6. General discussion

Summary

Samenvatting

Dankwoord

About the author 



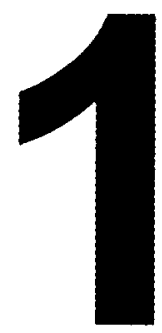

General introduction 


\section{NOMENCLATURE}

In 1931, Wills and associates showed that an autolyzed yeast preparation (marmite) was effective against megaloblastic anemia in pregnant women. In 1941, Mitchell and co-workers extracted a purified substance from spinach with acidic properties, which was an active growth factor for rats and Lactobacillus casei. They named the factor folic acid (from the Latin word for leaf, folium). Eventually, in 1946, Angier et al. determined the chemical structure of folic acid and achieved its synthesis.

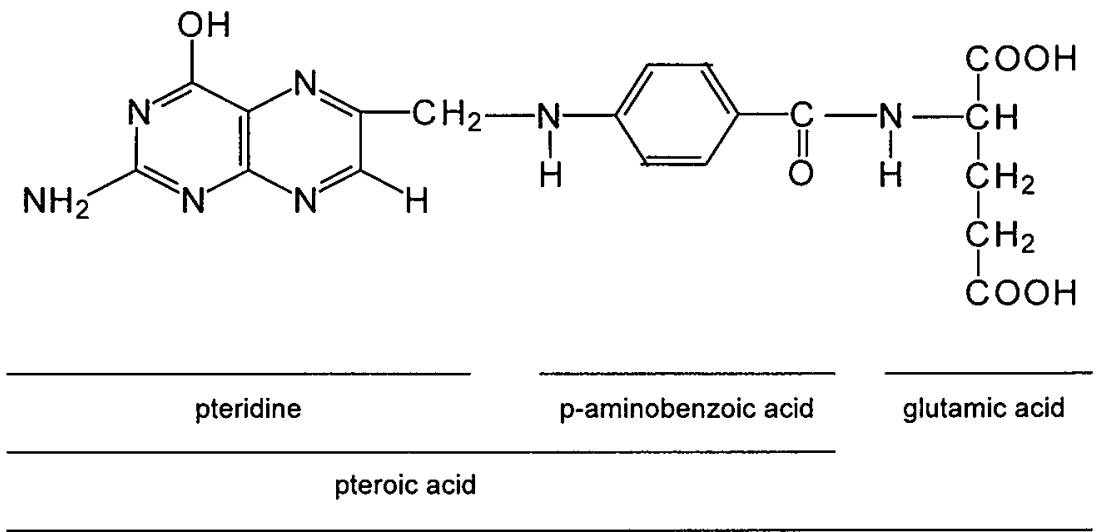

pteroyImonoglutamic acid (folic acid)

Figure 1. Structure of folic acid.

The structure in Figure 1 is known by the trivial name of folic acid, but is more precisely specified as pteroylmonoglutamic acid. Folic acid, with a fully oxidized pteridine ring does not occur naturally in significant amounts. It is the common, most stable, synthetic form used for food fortification.

Natural folates (Figure 2) comprise an extended family of mono- and polyglutamates (usually 5-7 glutamyl residues) of pteroic acid, which qualitatively exhibit the biological activity of folic acid. The pteridine ring is reduced to give the 7,8-dihydrofolate and subsequently 5,6,7,8-tetrahydrofolate. These reduced forms can be substituted with a covalently bonded one-carbon adduct attached to the nitrogen positions 5 or 10 , or bridged across these two positions. Besides tetrahydrofolate, the most substituted forms in the human diet are: 5-formyl, 10formyl, 5-methyl. Other frequently occurring folates are 10-formyldihydrofolate and 10-formylfolic acid. Glutamate residues are coupled in a gamma-peptide linkage. The folates differ widely with respect to their susceptibility to oxidative degradation, their thermal stability, and the $\mathrm{pH}$ dependence of their stability. Folate activity is gradually destroyed by exposure to UV-light. 
<smiles>[R]NCC[C@]1([2H])[C@@H](C)Nc2nc(N)nc(O)c2N1C</smiles><smiles>[R]NCCC1([2H])C([2H])N([2H])c2c(O)nc(N)nc2N1C</smiles><smiles>[R]N(C)CC[C@H]1CNc2c(O)nc(N)nc2N1</smiles><smiles>[R]N(C)CC1=Nc2c(O)nc(N)nc2NC1</smiles><smiles>[R]N(C)C=O</smiles><smiles>[R]NCCC1([2H])Nc2nc(N)nc(O)c2NC1[2H]</smiles>

10-formyl-folic acid<smiles>O=C(O)CCC(NC(=O)c1ccccc1)C(=O)O</smiles>

$\mathrm{R}=$ benzoylglutamic acid

Figure 2. Natural folates. 


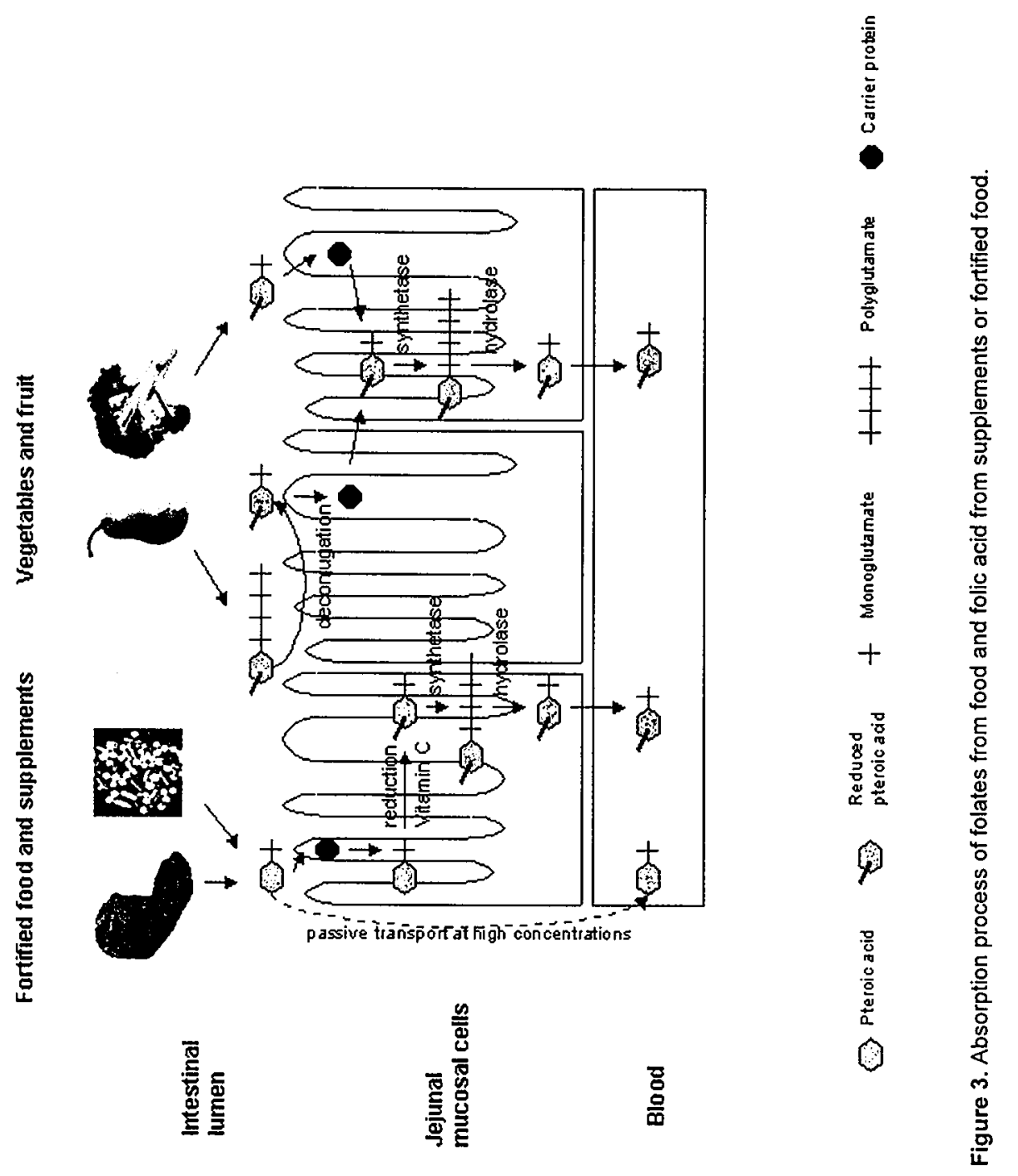




\section{METABOLISM}

Figure 3 shows the absorption process of folates from food and folic acid from fortified food or supplements. Folic acid from fortified foods or supplements is absorbed mainly by a saturable, $\mathrm{pH}$ dependent process, while at higher concentrations $(>10 \mu \mathrm{M})$, a nonsaturable mechanism involving passive diffusion contributes to folate absorption (Selhub et al. 1983, Mason 1990). Two folatebinding proteins exist in the jejunal brush border membrane (Leslie et al. 1972, Reisenauer et al. 1986, Shoda et al. 1993), but the role of these proteins in folate transport has not yet been determined (Gregory 1995). Prior to entering the blood circulation, folic acid undergoes reduction to tetrahydrofolate and either methylation or formylation in the mucosa cells. This reduction process is rather rate limited, so significant amounts of folic acid are found in plasma and urine (Gregory 1995). Kelly et al. (1997) showed that unaltered folic acid appeared in the blood circulation after a threshold intake of $266 \mu \mathrm{g}$ folic acid had been reached. Halsted (1991) hypothesized that folate polyglutamates are synthesized intracellularly by folate synthetase for folate-dependent reactions and are intracellularly hydrolyzed to folate monoglutamates for transport across the basolateral membrane to the portal circulation. Approximately $80 \%$ of all food folates exist as polyglutamates, which need to be cleaved into folate monoglutamates by pteroylpolyglutamate hydrolase (conjugase), present in the intestinal brush border, before it can be absorbed in the intestine. Conjugase is a zinc dependent enzyme with a $\mathrm{pH}$ optimum of 6.5 (Chandler et al. 1986, Gregory et al. 1987). Certain factors in food, like dietary fiber and certain organic acids in for example orange juice, tomatoes, or lima beans, may inhibit the deconjugation of polyglutamates (Wei et al. 1996, Wei \& Gregory 1998, Bailey et al. 1988, Keagy et al. 1988). 


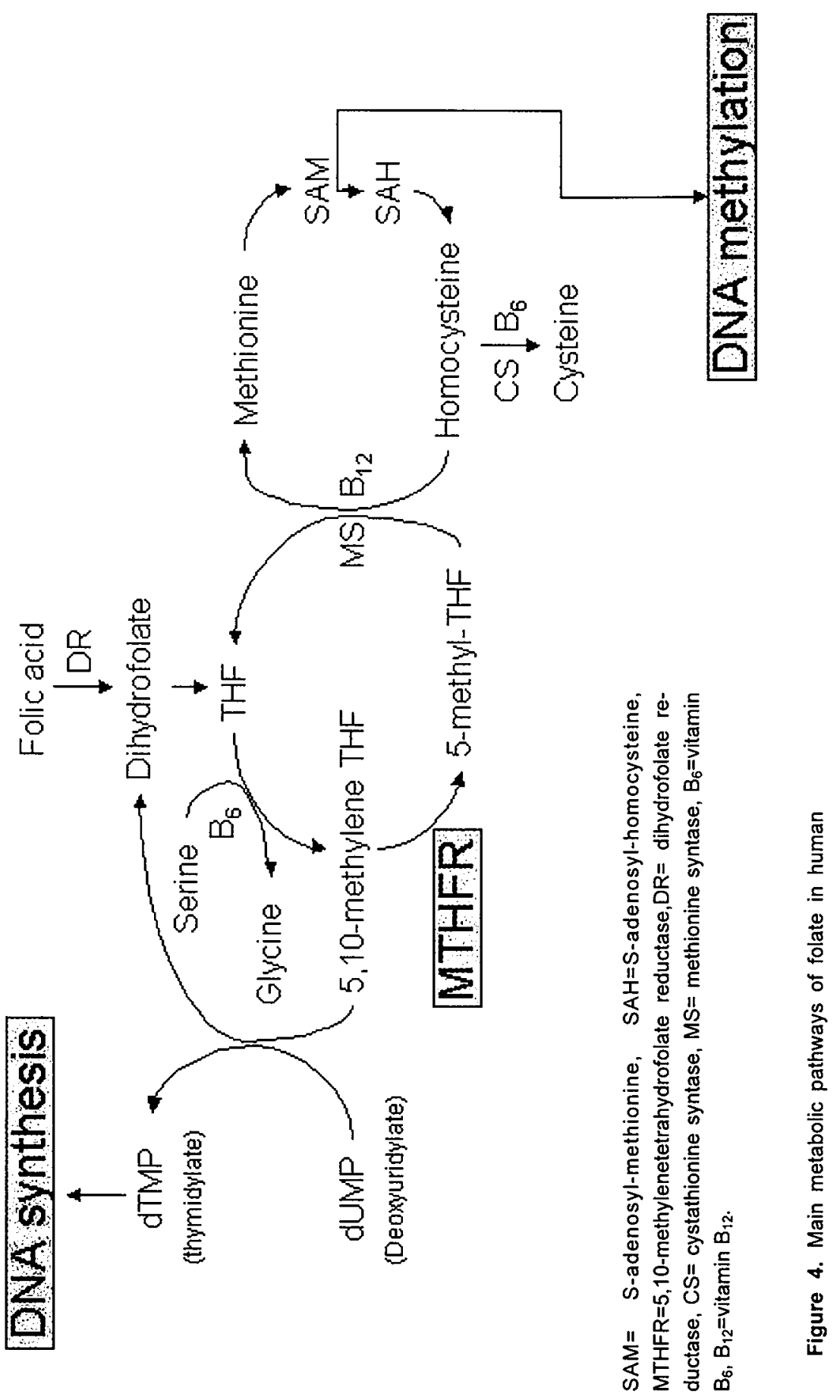




\section{FUNCTIONS}

Once in the portal circulation, $10-20 \%$ of the absorbed folate is retained by the liver on the first pass, providing an enterohepatic circulation, while the remainder is transported to other tissues (Steinberg 1984). The main function of folate is to carry one-carbon moieties, such as methyl and formyl groups. There are a number of important processes in which folates play a significant role in human health. The first of these is the synthesis of DNA, where folate coenzymes function in the synthesis of thymidylate and purines. The second is the folate-mediated transfer of one-carbon units from serine, which provides a major source of substrate in the one-carbon metabolism. One-carbon units are generated in the cell during metabolism and are carried from one reaction to another as folate derivates. Folates accept, transfer, and facilitate the enzymatic oxidation or reduction of onecarbon units. Before folic acid can carry a one-carbon unit, it must be reduced to the tetrahydro reduction state. The third process is the conversion of homocysteine to methionine, involving both a vitamin B12 coenzyme and 5methyltetrahydrofolate as substrates. In this process, the methyl group from 5methyltetrahydrofolate is transferred enzymatically to homocysteine to form methionine. This reaction is important because it serves as a major source of methionine for the synthesis of S-adenosyl-methionine, an important in vivo methylating agent (Gregory 1997).

\section{RECOMMENDED DAILY ALLOWANCES (RDA)}

The RDA is defined as the amount of nutrient that is needed to meet the requirements of $98 \%$ of the population. The RDA for folate in the Netherlands is currently $200-300 \mu \mathrm{g} / \mathrm{d}$ for adults and $40-60 \mu \mathrm{g} / \mathrm{d}$ for children, while the minimum requirement for adults is assumed to be $100 \mu \mathrm{g}$ folate per day and $400 \mu \mathrm{g}$ folic acid per day for pregnant women or women capable of becoming pregnant (Voedingsraad 1992, Gezondheidsraad/Noedingsraad 1993). Dietary Reference Intakes (DRIs) for folate have recently been reported by the US Committee on Dietary Reference Intakes of the Food and Nutrition Board, in conjunction with the Panel on folate and other B-vitamins and choline of the Institute of Medicine, National Academy of Sciences (Institute of Medicine, Panel on folate, other Bvitamins, and choline, 1998). The DRIs include a series of reference values for the intake of nutrients by Americans and Canadians. Dietary Folate Equivalents (DFE) are obtained by converting all forms of dietary folate, including synthetic folic acid in fortified products, to an amount that is equivalent to food folate. The estimated bioavailability of food folate is approximately $50 \%$ of that of folic acid (Sauberlich 1987). Pfeiffer et al. (1997) found a slight reduction (approx. 15\%) in the relative response of folic acid when consumed as a fortified product. Based on these data, 
a bioavailability estimate of $85 \%$ for folic acid consumed with food was used to derive DFEs. It was estimated that folic acid in fortified foods or taken with food is $85 / 50$ or 1.7 times more available than food folate. For example, $100 \mu \mathrm{g}$ provided as food folate (e.g., spinach) would equal $100 \mu \mathrm{g} \mathrm{DFE}$, and $100 \mu \mathrm{g}$ provided as folic acid in a serving of fortified breakfast cereal would equal $170 \mu \mathrm{g}$ DFE (Bailey 1998). For adults, a Recommended Dietary Allowance (RDA) of $400 \mu \mathrm{g}$ DFE/day was established. The recommendation for women capable of becoming pregnant is still $400 \mu \mathrm{g} / \mathrm{d}$ from supplements, because the scientific basis was insufficient to conclude that the risk of neural tube defects may be reduced by increased consumption of dietary folate (Bailey 1998).

\section{NEGATIVE EFFECTS OF INCREASING FOLIC ACID INTAKES}

In some countries folic acid fortification programs have started to increase folic acid intake by women in the reproductive age category. In the USA, for instance, fortification of cereals and grains with folic acid began some time after 1996, and since January 1998, all cereal-grain products are fortified with $140 \mu \mathrm{g}$ folic acid per $100 \mathrm{~g}$. There are some concerns about the danger of such a policy to segments of the public with unrecognized vitamin B12 deficiency, because folic acid can mask the hematological abnormalities and allow the neurological complications to progress or even accelerate when intakes of folic acid exceed $1 \mathrm{mg}$ per day (Rothenberg 1999). Flynn and Enright (2000) reported a case of a vitamin B12deficient woman who used folic acid supplements. Although a healthy baby was born, the mother suffered a severe neuropathy. Furthermore, as described above, unaltered folic acid has been found to appear in the blood circulation after a threshold intake of $266 \mu \mathrm{g}$ folic acid has been reached (Kelly et al. 1997). Although it is assumed that sufficient amounts of dihydrofolate reductase are present in the tissues to reduce unmetabolized folic acid (Scott 1999), the long-term effects of this folic acid exposure are not known. Folic acid may also counteract the anticonvulsant activity of some drugs used to treat epilepsy (Chanarin et al.1960), although findings in the literature are contradictory (Dipalma \& Ritchie 1977).

Recently, safe upper limits (UL) for the intake of folic acid were published (Institute of Medicine, Panel on folate, other B-vitamins, and choline 1998, European Commission Scientific Committee on Food 2000, Gezondheidsraad 2000). The safe upper limit was based on data related to either reports of the highest intake level associated with no adverse effect (no observed effect level, or NOAEL) or the lowest observed adverse effect level (observed adverse effect level (LOAEL). Since data for folic acid were insufficient to determine a NOAEL, the UL estimate was based on studies that identified the LOAEL. The data suggesting adverse effects were taken from more than 100 case reports in which B12-deficient patients receiving a dose of $\geq 5 \mathrm{mg} /$ day folic acid supplements experienced 
progression of neurological disorders. These 100 case reports contrasted with only eight well-documented cases associated with neurological disorders in vitamin B12-deficient patients who where taking doses of $<5 \mathrm{mg}$ folic acid/day. The LOAEL was defined as $5 \mathrm{mg}$ folic acid/day, which was converted to the UL by dividing by an uncertainty factor of 5 to deal with recognized gaps in data and incomplete knowledge of variability in response. The UL was therefore set at $1000 \mu \mathrm{g} /$ day for all adults, including pregnant and lactating women (Institute of Medicine, Panel on folate, other B-vitamins, and choline 1998, Bailey 1998). The European Commission and the Dutch Health Council followed the US Committee in setting an UL of $1 \mathrm{mg}$ of folic acid per day (European Commission Scientific Committee on Food 2000, Gezondheidsraad 2000).

\section{ETIOLOGY OF FOLATE RELATED DISORDERS}

\section{Neural Tube Defects}

A number of diseases are associated with the metabolism of folic acid illustrated in the scheme (figure 4). It has been clear that folic acid plays a role in preventing recurrence and occurrence of neural tube defects (NTD) (MRC Vitamin Study Research group 1991, Czeizel et al. 1992). Although, it has been shown that many studies looking into the question of the relationship of folic acid and NTD the last 30 to 35 years are far from having reached a consensus, in part perhaps because they have largely been based on investigatory methods with inherent limitations as selection bias, recall bias, definitions of NTDs, spontanious abortions were not examined and included in the studies, studies were nor randomized and double blind, women did not comply with protocol and it was not certain that the controls did not take vitamins (Kalter 2000). In the Netherlands, approximately 250 children with a neural tube defect are born each year (EUROCAT Working group 1998). Based on the results of the trials referred to above, the Nutrition Health Council in 1992 recommended women planning to become pregnant to take a folic acid supplement of 400-500 $\mathrm{gg}$ daily. In contrast with the established protective effect of supplemental folic acid, data are insufficient to conclude that increased intake of naturally occurring food folate is associated with NTD risk reduction (Boddie et al. 2000). The mechanism or mechanisms by which folic acid reduces the risk of NTD is not known. Increasing folate and/or folic acid intake might overcome a deficiency in the production of methionine, S-adenosylmethionine, or nucleotides near the time of neural tube closure. Once they have been absorbed and have entered the blood circulation, the biochemical roles of folates from foods and supplemental folic acid in the cellular metabolism are identical. A proposed defect in the cleavage process of food folate polyglutamates by jejunal brush border conjugase may account for the reduced bioefficacy of food folates. 
It is likely that nutrient status is under considerable genetic control (Mitchell et al. 1997). The variant 5,10-methylenetetrahydrofolate reductase or MTHFR (with C-to$T$ substitution at nucleotide 677 , or $\mathrm{C677T}$ ) is a genetic polymorphism affecting folate status (Molloy et al. 1997). This mutation causes thermolability and reduced activity of MTHFR, leading to lower levels of 5-methyltetrahydrofolate, accumulation of 5,10-methylenetetrahydrofolate, increased plasma homocysteine levels, and changes in the cellular composition of one-carbon folate derivatives. About $5-15 \%$ of the general population are homozygous for this variant, which causes mild hyperhomocysteinemia and is positively associated with the development of NTD and coronary artery disease. This suggests that a substantial proportion of people in the general population may require increased levels of folate intakes.

\section{Cardiovascular disease}

Several studies have shown that cardiovascular disease risk is associated with high levels of plasma homocysteine (Stampfer et al., 1992, Boushy et al. 1995, Selhub et al. 1995, Verhoef et al. 1996). Boushy calculated that a homocysteine decrease of $5 \mu \mathrm{mol} / \mathrm{l}$ would result in a $40 \%$ lower risk of cardiovascular diseases. Boushy based this result on subjects with initially high plasma homocysteine levels $(>16 \mu \mathrm{mol} / \mathrm{l})$. For subjects with normal homocysteine levels, van 't Veer et al. (1997) calculated that an additional folic acid intake of $250 \mu \mathrm{g} / \mathrm{d}$ might result in a $10 \%$ decrease in the risk of cardiovascular diseases. Increased intake of folic acid as well as food folates was found to decrease plasma homocysteine levels (Jacob et al. 1994, Ubbink 1997, Brattström et al. 1998, Brouwer et al. 1999a, Brouwer et al. 1999b, Riddell et al. 2000). Brouwer et al. (1999) found an approximately $15 \%$ decrease in plasma homocysteine after an additional folic acid intake of $250 \mu \mathrm{g} / \mathrm{d}$ or an additional dietary folate intake of $350 \mu \mathrm{g} / \mathrm{d}$. The main sources of dietary folate were vegetables and fruits. Subjects had initial homocysteine levels of approximately $11 \mu \mathrm{mol} / \mathrm{L}$. Intervention studies are currently underway to investigate whether homocysteine lowering therapies with folic acid lead to a decrease in cardiovascular disease.

\section{Colorectal cancer}

Cancer of the colon and the rectum is the fourth most common incident cancer and cause of death from cancer throughout the world. An estimated 875,000 cases occurred in 1996, accounting for $8.5 \%$ of all new cases of cancer. Incidence of and death rates from this cancer are generally increasing, most of all in the developed world and in urban areas of the developing world. Colorectal cancer risk is thought to be modified mainly by food and nutrition (World Cancer Research Fund/American Institute for Cancer Research 1997). In the Netherlands, 8348 incident cases of colorectal cancer occurred in 1996 (4324 men, 4024 women) (Netherlands Cancer Registry 1996). 
In 1991, Freudenheim et al. first proposed the hypothesis that dietary folate intake may be associated with colorectal cancer risk. Possible mechanisms for the development of colorectal cancer can also be deduced from figure 4. Folate deficiency causes massive incorporation of uracil into human DNA, which may result in the initiation of neoplastic transformation (Blount et al. 1997). In addition reduced methylation of DNA has been observed in human colorectal cancer (Feinberg \& Vogelstein 1983). A mutation in the MTHFR gene may also play a positive or negative role regarding colorectal cancer, although findings have so far not been consistent ( $\mathrm{Ma}$ et al. 1997, Chen et al. 1996, Slatterly et al. 1999). Individuals with the homozygous mutant MTHFR genotype (677TT) have a 40-50\% reduced colorectal cancer risk compared with those with the heterozygous $(677 \mathrm{CT}$ ) or normal $(677 \mathrm{CC})$ genotype. This protective effect associated with the MTHFR $677 T T$ genotype, however, was only observed in men with adequate folate status. In those individuals with inadequate dietary folate intake or systemic folate deficiency, the protective effect conferred by the MTHFR 677TT genotype was completely suppressed, and in some cases a trend toward increased colorectal cancer risk was observed. This observation suggests possible gene-nutrient interactions between folate status and the MTHFR 677 genotype in colorectal carcinogenesis (Kim 2000).

Besides these well-established relationships between impairments of folate metabolism and disease, a number of other possible relationships have been proposed. It has been shown that abnormal folate metabolism and mutations in the methylenetetrahydrofolate reductase gene may be risk factors for Down's syndrome (James et al. 1999). In addition low blood levels of folate and vitamin B12, and elevated homocysteine levels are associated with Alzheimer disease (Clarke et al. 1998). Furthermore low folate intake may be a risk factor for recurrent early pregnancy loss (Nelen 2000).

\section{AIM OF THE THESIS}

The ultimate goal of the research reported on in this thesis was to explore the association between the dietary intake of folates and the risk of colorectal cancer in the Netherlands. This association was studied using data from the Netherlands Cohort Study on diet and cancer. The assessment of dietary folate intake in that study encountered a number of problems.

First, no up-to-date folate data were available in the Dutch food composition table. Although average folate intakes from foods for adults, as reported from various European countries, range between 168 and $326 \mu \mathrm{g} / \mathrm{d}$ (de Bree et al. 1997), a comparison of folate intakes between different countries is impossible due to the absence of reliable data for folates in food products. 
Second, differences in analytical methods and sample preparation are thought to be the most crucial factors impeding an accurate determination of dietary folate intake. In 1996, a European working group "COST 1999" compared folate data in food composition tables for some vegetables, milk, bread, and cereals from 7 European countries. Total folate was measured mostly by microbiological assay. Limited result were based on HPLC analysis. The results of the microbiological assay showed a 2-3 fold variation. HPLC gave higher folate values for liver than microbiological assays. Results for pig liver were 10 times higher, beef liver 3 times and chicken liver 2 times higher (Finglas 1996). Other problems related to folate intake measurement comprise possible differences in the folate content of foods depending upon growth and storage conditions, and differences in food preparation methods that may affect the content of the food as eaten.

Third, the microbiological methods commonly used for folate analysis can only quantify total folate. Certain non-folate compounds may either stimulate or inhibit bacterial growth, resulting in unreliable data. Above all, the apparent reduced bioavailability of polyglutamates compared to monoglutamates, as well as the possible difference in bioavailability of different folate vitamers (Gregory 1995), indicate the need for a validated method for the analysis of individual folate vitamers in foods. Knowledge of the bioavailability of folate, especially that of different types of folate in foods, is limited. Factors that might affect folate availability are: intestinal deconjugation, intestinal stability, drugs, and food containing brush border conjugase inhibitors. Bioavailability assessment methods comprise rat and chick bioassays, short-term human studies, long-term human studies, in vitro methods, and isotopic methods. Many methods have conceptual limitations. For instance, results of in vitro studies may not predict folate bioavailability in vivo, while stable isotope methods may not predict bioavailability of naturally occurring folates. So far, most methods have yielded information regarding the bioavailability of total folate relative to folic acid, rather than the absolute bioavailability of total folate or the various folate vitamers.

This thesis addresses a number of these emerging issues, before finally investigating the association between dietary folate intake and colorectal cancer risk.

\section{OUTLINE OF THE THESIS}

Chapter 2 describes a validated HPLC method for determining folates in vegetables, milk powder, liver, and flour. The method is able to detect the most abundant folate forms naturally present in foods and establishes the amounts of folate monoglutamates and polyglutamates. The system can also quantify folic acid, used for fortification. 
The validated method described in chapter 2 was used to determine the folate content of 125 food products, comprising the most important foods that contribute to folate intake. The results, which are reported in Chapter 3, are used to estimate folate intake for a representative sample of the Dutch population.

lleostomy volunteers with an intact small intestine are pre-eminently suitable for a study of absolute folate absorption, because absorption of folates takes place exclusively in the small intestine. Chapter 4 reports the results of a bioavailability study of various naturally occurring folates and supplemental folic acid in healthy ileostomy volunteers. The deconjugation process was investigated as a possible limiting factor in the absorption of folates. The study attempted to validate the use of the serum folate response curve from food compared to folic acid as a proxy variable for food folate bioavailability.

The new database presented in Chapter 3 was used to examine the association between the intake of total folates as well as individual folate vitamers and the risk of colon and rectal cancer, using the Netherlands Cohort Study on diet and cancer. Results are presented in Chapter 5.

Chapter 6 discusses the main conclusions and implications of the studies described in this thesis on the role of dietary folates in human nutrition.

\section{REFERENCES}

Bailey LB, Barton LE, Hillier SE, Cerda JJ. Bioavailability of mono and polyglutamyl folate in human subjects. Nutr Rep Int 1988;38,3:509-18.

Bailey LB. Dietary Reference intakes for folate: the debut of dietary folate equivalents. Nutr Rev 1998;56,10:294-9.

Blount BC, Mack MM, Weht CM, MacGregor JT, Hiatt RA, Wang G, Wickramasinghe SN, Everson RB, Ames $B N$. Folate deficiency causes uracil misincorporation into human DNA and chromosome breakage: implications for cancer and neuronal damage. Proc Natl Acad Sci USA 1997;94:3290-5.

Boddie AM, Dedlow ER, Nackashi JA, Opalko FJ, Kauwell GPA, Gregory JF III, Bailey LB. Folate absorption in women with a history of neural tube defect-affected pregnancy. Am $\mathrm{J}$ Clin Nutr 2000;72:154-8.

Boushy CJ, Beresford SAA, Omenn GS, Motulsky AG. A quantitative assessment of plasma homocysteine as a risk factor for vascular disease. JAMA 1995;274,13:1049-57.

Brattström L, Landgren $F$, Israelsson $B$ et al. Lowering blood homocysteine with folic acid based supplements: meta-analysis of randomised trials. Br Med J 1998;316:894-8.

Brouwer IA. van Dusseldorp M. Thomas CMG. Low-dose folic acid supplementation decreases plasma homocysteine concentrations: a randomized trial. Am J Clin Nutr 1999a;69:99-104.

Brouwer IA, van Dusseldorp M, West CE, Meyboom S, Thomas CM, Duran M, van-het-Hof KH, Eskes $T K$, Hautvast J G, Steegers-Theunissen RP. Dietary folate from vegetables and citrus fruit decreases plasma homocysteine concentrations in humans in a dietary controlled trial. J Nutr 1999b;129:1135-9.

Chanarin I. et al. Megaloblastic anaemie due to phenobarbitone. The convulsant action of therapeutic doses of folic acid. Br Med J 1960;1:1099-1102.

Chandler CJ, Wang TTY, Halsted $\mathrm{CH}$. Pteroylpolyglutamate hydrolase from human jejunal brush borders. Purification and characterization. J Biol Chem 1986;261:928-33. 
Chen J, Giovannucci E, Kelsey K, Rimm EB, Stampfer MJ, Colditz GA, Spiegelman D, Willett WC, Hunter DJ. A methylenetetrahydrofolate reductase polymrphism and the risk of colorectal cancer. $J$ Cancer Research 1996;56:4862-4.

Clarke R, Smith D, Jobst KA, Refsum H, Sutton L, Ueland PM. Folate, vitamin B, and serum total homocysteine levels in confirmed Alzheimer Disease. Arch Neurol 1998;55:1449-55.

Czeizel AE, Dudás I. Prevention of the first occurrence of neural tube defects by periconceptional vitamin supplementation. N Engl J Med 1992;327:1832-5.

de Bree $A$, van Dusseldorp $M$, Brouwer IA, van het Hof $K H$, Steegers-Theunissen RPM. Folate intake in Europe: recommended, actual and desired intake. Eur J Clin Nutr 1997;51:643-60.

Diplama JR, Ritchie RM. Vitamin toxity. Ann Rev Pharmacol Toxicol 1977;17:133-48.

Eurocat Working Group. Eurocat registration of congenital anomalies. Northern Netherlands and Southwestern Netherlands 1998. Tables 1981-1996, Groningen, Department of Medical Genetics, University of Groningen.

European Commission, Scientific Committee on Food (SCF). Opinion of the SCF on the Tolerable Upper Intake Level of Folate (2000).

Feinberg AP, Vogelstein B. Hypomethylation distinguishes genes of some human cancers from normal counterparts. Nature 1983;301:90-1.

Finglas PM. Analysis of carotene and folate values in European Food composition tables, part 2: Folates. Report European working group COST 99, 1996.

Flynn $\mathrm{C}$. Enright $\mathrm{H}$. Fortification of foods with folic acid. Correspondence to the editor. $\mathrm{N}$ Engl $\mathrm{J}$ Med 2000;343:970-2.

Freudenheim JL, Graham S, Marshall JR, Haughy BP, Cholewinsky S, Wilkinson G. Folate intake and carcinogenesis of the colon and rectum. Int J Epidemiol 1991;20:368-74.

Gezondheidsraad. Risico's van foliumzuurverrijking. Den Haag: Gezondheidsraad, 2000; publicatie nr $2000 / 21$.

GezondheidsraadNoedingsraad. Vervolgadvies inzake foliumzuurvoorziening in relatie tot neuraalbuisdefecten. Den Haag: Voorlichtingsbureau voor de Voeding, 1993.

Gregory JF III, Ink SL, Cerda JJ. Comparison of pteroylpolyglutamate hydrolase (folate cinjugase) from porcine and human intestinal brush border membrane. Comp Biochem Phisiol 1987;88B:1135-41.

Gregory JF III. The bioavailability of folate. In: Bailey L, ed. Folate in helath and disease. M. Dekker, New York, NY. 1995:195-235.

Gregory JF III. Bioavailability of folate. Eur J Clin Nutr 1997;51, Suppl. 1, S54-S59.

Halsted $\mathrm{CH}$. Jejunal brush-border folate hydrolase, a novel enzyme. West J Med 1991;155:605-9.

Holden J, Beecher G, Doherty R, Davis C, Finglas P. Evaluation system for the assessment of folate composition data of foods. Proceeding paper from 16 th International Congress of Nutrition, Montreal Canada, 1997.

Institute of Medicine, Panel on Folate, other B-vitamins, and choline. Dietary Refernce intakes: thiamin, riboflavin, niacin, vitamin B6, folate, vitamin B12, panthothenic acid, biotin, and choline. Washington, DC: National Academy Press, 1998.

Jacob RA, Wu MM, Henning SM, Swendseid ME. Homocysteine increases as folate decreases in plasma of healthy men during short-term dietary folate and methyl group restriction. I Nutr 1994;124,1072-80.

James SJ, Pogribna M, Pogribny IP, Melnyk S, Hine RJ et al. Abnormal folate metabolism and mutation in the methylenetetrahydrofolate reductase gene may be maternal risk factors for Down syndrome. Am J Clin Nutr 1999;70,495-501.

Kalter H. Folic acid and human malformations: a summary and evaluation. Repro Tox 2000;14:463-76.

Keagy PM, Shane B, Oace SM. Folate bioavailability in humans: effects of wheat bran and beans. Am J Clin Nutr 1988;47:80-8.

Kelly P, McPartlin J, Goggins M, Weir DG, Scott JM. Unmetabolized folic acid in serum: acute studies in subjects consuming fortified food and supplements. Am J Clin Nutr 1997;65:1790-5. 
Kim Y-I. Methylenetetrahydrofolate reductase polymorphisms, folate, and cancer risk: A paradigm of Gene-Nutrient interactions in carcinogenesis. Nutr Rev 2000;58,7:205-9.

Leslie GI, Rowe PB. Folate binding by the brush border membrane proteins of small epithelial cells. Biochemistry 1972;9:1696-1703.

Ma J, Stampfer MJ, Giovannucci E, Artigas C, Hunter DJ, Fuchs C, Willett WC, Selhub J, Hennekens $\mathrm{CH}$, Rozen R. Methylenetetrahydrofolate reductase polymorphism, dietary interactions and risk of colorectal cancer. Cancer Research 1997;57:1098-1102.

Mason JB. Intestinal transport of monoglutamyl folates in mammalian systems. In: Picciano MF, Stokstad ELR, Gregory JF III, eds. Folic acid metabolism in health and disease. New York: WileyLiss, 1990:47-64.

Mitchell LE, Duffy DL, Duffy $P$, Bellingham G, Martin NG. Genetic effects on variation in red-blood-cell folate in adults: implications for the familial aggregation of neural tube defects. Am J Human Genet 1997;60:433-8.

Molloy AM, Daly S, Mills JL, Kirke PN, Whitehead AS, Ramsbottom D, Conley MR, Weir DG, Scott JM. Thermolabile variant of 5,10-methylenetetrahydrofolate reductase associated with low red-cell folates: implications for folate intake recommendations. The Lancet 1997;349:1591-3.

MRC Vitamin Study Research Group. Prevention of neural tube defects: Results of the Medical Research Council Vitamin Study. The Lancet 1991;338:131-7.

Nelen WLDM. Risk factors for recurrent early pregnancy loss, hyperhomocysteinaemia, thrombophilia and impared detoxification. 2000. Thesis University of Nijmegen.

Netherlands cancer registry 1996, report.

Pfeiffer CM, Rogers LM, Bailey LB, Gregory JF III. Absorption of folate from fortified cereal-grain products and supplemental folate consumed with or without food determined by using a dual-label stable-isotope protocol. Am J Clin Nutr 1997;66:1388-97.

Reisenauer AM, Chandler $\mathrm{CJ}$, Halsted $\mathrm{CH}$. Folate binding and hydrolysis by pig intestinal brush border membranes. Am J Physiol 1986;251:G481-G486.

Ridell LJ, Chisholm A, Williams S, Mann JL. Dietary strategies for lowering homocysteine concentrations. Am J Clin Nutr 2000;71,6:1448-54.

Rothenberg SP. Increasing the dietary intake of folate: Pros and cons. Semin Hematol 1999;36:65-74.

Sauberlich HE, Kretsch MJ, Skala JH, Johnson HL, Taylor PC. Folate requirement and metabolism in nonpregnant women. Am J Clin Nutr 1987;46:1016-28.

Scott JM. Folate and vitamin B12. Proc Nutr Soc 1999;58:441-8.

Slatterly ML, Potter JD, Samowitz W, Scaffer D, Leppert M. Methylenetetrahydrofolate reductase, diet, and risk of colon cancer. Cancer Epidemiol Biomarkers Prev 1999;8:513-8.

Stampfer MJ, Malinow MR, Willett WC, Newcomer LM, Upson B, Ullmann D, Tishler PV, Hennekens $\mathrm{CH}$. A prospective study of plasma homocysteine and risk of myocardial infarction in US physicians. JAMA 1992;268:877-81.

Selhub J, Dhar GJ, Rosenberg IH. Gastrointestinal absorption of folates and antifolates. Pharmac Ther 1983;20:397-418.

Selhub J, Jacques PF, Bostom AG, D'Agostino RB, Wilson PW, Belanger AJ, O'Leary DH, Wolf PA, Schaefer EJ, Rosenberg $\mathrm{HH}$. Association between plasma homocysteine concentrations and extracranial carotid-artery stenosis. N Engl J Med 1995;332:286-91.

Shoda R, Mason JB, Selhub J, Rosenberg IH. Folate binding in intestinal brush border membranes: evidence for the presence of two binding activities. J Nutr Biochem 1993:1:257-61.

Steinberg SE. Mecanisms of folate homeostasis. Am J Physiol 1984;246:G319-G324.

Ubbink JB. The role of vitamins in the pathogenesis and treatment of hyperhomocyst(e)inaemia. J Inheret Metab Dis 1997;20:316-25.

van 't Veer $P$, Jansen MCJF, van Dusseldorp $M$, Kok FJ. Relevantie van voedselverrijking: de visie van de epidemioloog. In: Bespiegelingen over voor en tegen van voedselverrijking. Ed. Van Binsbergen JJ, van Dusseldorp M. Bohn Stafleu van Loghum, Houten/Diegem 1997:14-28. 
Verhoef P, Stampfer MJ, Buring JE, Gaziano JM, Allen RH, Stabler SP, Reynolds RD, Kok FJ, Hennekens $\mathrm{CH}$, Willett WC. Homocysteine metabolism and risk of myocardial infarction: relationship with vitamins B6, B12, and folate. Am J Epidemiol 1996;134:845-59.

Voedingsraad. Nederlandse Voedingsnormen 1989. Advies opgesteld door de Commissie Voedingsnormen, Den Haag 13 juli 1989. 2e druk. Den Haag: Voorlichtingsbureau voor de voeding, 1992.

Wei MM, Bailey LB, Toth JP, Gregory JF III. Bioavailability for humans of deuterium-labeled monoglutamyl and polyglutamyl folates is affected by selected foods. J Nutr 1996;126:3100-8.

Wei MM, Gregory JF III. Organic acids in selected foods inhibit intestinal brush border pteroylpolyglutamate hydrolase in vitro: potential mechanism affecting the bioavailability of dietarypolyglutamyl folate. J Agric Food Chem 1998;46:211-9.

World Cancer Research Fund/American Institute for Cancer Research. Food, Nutrition and the prevention of cancer: a global perspective. 


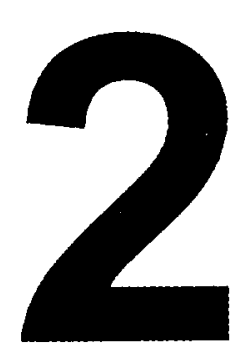

\section{A validated liquid chromatographic method for determining folates in vegetables, milk powder, liver, and flour}

Erik J.M. Konings

Journal of AOAC INTERNATIONAL 1999;82,1:119-27 


\section{ABSTRACT}

A liquid chromatographic (LC) method was elaborated for determining folates in foods. Folates were extracted by homogenizing in buffer and heat treatment. A portion was incubated with an enzyme preparation containing conjugase, amylase, and protease. After purification by affinity chromatography, folate monoglutamates were determined by reversed-phase LC with fluorescence and diode array detection. Gradient elution with phosphate buffer and acetonitrile was used to separate vitamers. The most abundant folate forms naturally present in foods were detected, including tetrahydrofolic acid, 5-methyltetrahydrofolic acid, and 5formyltetrahydrofolic acid. 10-Formylfolic acid could be detected by applying a second fluorescence detector. Folic acid, used for fortification, might also be quantified with this system. The difference between folate concentrations in sample extracts, with and without treatment of conjugase, is a measure of the quantity of poly glutamates in the food matrixes. An additional treatment with conjugase, amylase, and protease reflects the amount of matrix-bound folates. The LC-system gave a linear response over the range $0-100 \mathrm{ng} / \mathrm{mL}$. Detection limit for these compounds were $7 \mathrm{pg} / \mathrm{mL}$ for tetrahydrofolic acid and 5-methyltetrahydrofolic acid and $59 \mathrm{pg} / \mathrm{mL}$ for 10 -formylfolic acid (signal-to-noise ratio $\geq 3$ ) when $100 \mu \mathrm{L}$ was injected. Detection limits for 5-formyltetrahydrofolic acid and folic acid were 1 $\mathrm{ng} / \mathrm{mL}$. Repeatability relative standard deviation values for separate folates in 3 candidate Certified Reference Materials (CRMs)-mixed vegetables (CRM 485), pig liver (CRM 487), and whole-meal flour (CRM 121)- and a certified Reference Material milk powder (CRM 421) varied from 3.3 to $21.0 \%$ for the concentration range $1.8-1440 \mu \mathrm{g} / 100 \mathrm{~g}$. Recoveries ranged from $73-109 \%$. Use of amylase and protease was advantageous. Use of a commercially available folate-binding protein for cleanup saved time and money and was effective. Results for 5methyltetrahydrofolic acid were in good agreement with results obtained with other LC methods. Results for total folates were lower than results obtained with microbiological methods. 


\section{INTRODUCTION}

Folates are polyglutamates (usually 5-7 glutamyl residues of pteroic acid and related analogues exhibiting qualitative biological activity of the vitamin folic acid. Folic acid is the monoglutamate of pteroic acid. It is not a natural physiological form of the vitamin but is applied mainly for enrichment of foods.

Folates play a role in neural tube defects (MRC Vitamin Study Research Group 1991, Czeizel et al. 1992). Epidemiological evidence suggest that elevated homocysteine in plasma is an independant risk factor for cardiovascular disease (Boushy et al. 1995). Higher intakes of folic acid reduce homocysteine levels. A US prospective cohort study found that high dietary intake of folates is negatively associated with colorectal adenomas (Giovannucci et al. 1993). Dietary intake of folates could be an important issue in these diseases.

The average intake of adult men and women in various European countries ranges from 150 to $400 \mu \mathrm{g} /$ day (van den Berg et al. 1997, de Bree et al. 1997). A comparison of intakes is not always possible because not all countries, including the Netherlands, own or have reliable databases for folates in food products. Most of the time data from other (foreign) food tables are used.

The purpose of this study was to elaborate and validate a method for determining folates in foods that will be used to produce data for The Netherlands' food table. The total folate content of foods is usually determined by microbiological assay (Finglas et al. 1993). This method cannot differentiate among various folates. The organism commonly used, Lactobacillus rhamnosus var. Casei, responds to monoglutamate as well to di- and triglutamylfolates (Martin 1995) but to unequal extents. Certain compunds can either stimulate or inhibit bacterial growth, resulting in unreliable data. As shown in recent papers (De Souza et al. 1990, Pfeiffer et al. 1997, Martin et al. 1990, Tamura et al. 1997), previously used methods might not have been applying optimal extraction conditions. Use of better methods to analyze folates in foods might result in more reliable data.

Bioavailability of folates from food has been estimated at about $50 \%$ (Sauberlich et al. 1987). Bioavailability of monoglutamyl folates might vary between 70 and $120 \%$ with respect to folic acid (100\%) (Tamura et al. 1973). Monoglutamyl folates are almost fully absorbed in the jejunum. Under certain circumstances, polyglutamates are not absorbed. For good evaluation of bioavailability studies, more detailed information about the folate content of foods is needed. Liquid chromatography (LC) may ensure separation and determination of different folate forms (Pfeiffer et al. 1997, Gregory et al. 1984, Vahteristo et al. 1996). It may also differentiate between amounts of monoglutamates and polyglutamates. Recent papers (Vahteristo et al. 1997, Müller 1993) dealing with food analyses describe problems in identifying peaks when ion exchange is used at the purification and concentration stages of folate analysis before LC. Therefore a more specific 
cleanup, like affinity chromatography, is used in this study to isolate folates from food matrixes.

Folates are extracted by homogenizing samples in buffer and heat treatment, followed by deconjugation of polyglutamates and destruction of matrix by protease and amylase. After cleanup of extracts by affinity chromatography, portions are injected into the LC system. Folates are determined by reversed-phase LC with fluorescence and diode array detection. Gradient elution with phosphate buffer and acetonitrile are used to separate vitamers. With this procedure, the most abundant folate forms naturally present in foods were determined, including tetrahydrofolate ( $\mathrm{H}_{4}$ folate), 5-methyltetrahydrofolate $\left(5-\mathrm{CH}_{3}-\mathrm{H}_{4}\right.$ folate), and 5-formyltetrahydrofolate (5-CHO- $\mathrm{H}_{4}$ folate). 10-Formylfolic acid (10-HCO-folic acid), 10-formyldihydrofolate (10-HCO- $\mathrm{H}_{2}$ folate), and folic acid could be detected as well. Analytical results for a mixed vegetable sample, milk powder, pig liver, and whole-meal flour are presented.

\section{METHOD}

\section{Apparatus and Materials}

Trade names and sources are for user information only.

(a) Homogenizer.- (e.g. Uitra Turrax or equivalent).

(b) Water bath. - Boiling.

(c) LC system. - Equipped with secondary gradient pump, $100 \mu$ injection loop, autosampler adjustable to $2-4^{\circ} \mathrm{C}$, column oven adjustable to $20^{\circ} \mathrm{C}$, two fluorescence detectors capable of excitation at 280 and $359 \mathrm{~nm}$ and emission at 360 and $460 \mathrm{~nm}$ respectively. Diode array detector (DAD), data handling system (Waters Chromatography, Milford, MA). Chromatogram at DAD was monitored at $280 \mathrm{~nm}$.

(d) Spectrometer. - Adjustable between 200 and $400 \mathrm{~nm}$ (Perkin-Elmer Corp., Norwalk, CT, or equivalent).

(e) LC column. - (1) Guard column.- $15 \times 4.6 \mathrm{~mm}$, stainless steel, packed with Vydac 201TP $\mathrm{C}_{18}(10 \mu \mathrm{m}$ particle size) Ready to use columns from Allech Associates, Inc., Deerfield, IL , is suitable. (2) Separator column.- $250 \times 4.6$ $\mathrm{mm}$ id, stainless steel, packed with Vydac $201 \mathrm{TP} 54$ (5 $\mu \mathrm{m}$ particle size). Vydac, Hesperia, CA, is suitable.

(f) Dialysis tubing.- Membrane with molecular weight cut-off (MWCO) of 1200014000. Maximum volume of $300 \mathrm{~mL}$ Spectra Por 4 from Spectrum, Houston, $\mathrm{TX}$ is suitable.

(g) Affinity chromatography columns.- $15 \mathrm{~mL}$. Econo chromatography columns from Bio-Rad Laboratories (Hercules, CA) are suitable.

(h) Vacuum manifold.- manifold for affinity chromatography columns (Waters).

(i) Centrifuge.- Adjustable at $5000 \times \mathrm{g}$ and $5^{\circ} \mathrm{C}$. 
(j) Shaking waterbath.- Adjustable at $37^{\circ} \mathrm{C}$.

\section{Reagents}

All reagents should be of analytical purity, unless otherwise stated. Water used should be Milli-Q grade or equivalent.

Caution: Consult safety data sheets or labels for additional information on safe handling, toxicity, flammability, and explosivity of chemicals. Trade names and sources are for user information only.

(a) Solvents and reagents. - Acetonitrile (LC grade), $L(+)$-ascorbic acid, dipotassium hydrogen phosphate, 2-mercaptoethanol, concentrated phosphoric acid, potassium hydroxide, sodium acetate, sodium ascorbate, sodium azide, sodium dihydrogen phosphate, sodium hydrogen carbonate, sodium tetrahydro boric acid decahydraat (E. Merck, Darmstadt, Germany); 2[N-cyclohexylamino]ethanesulfonic acid (CHES), dithioerytreitol, ethanolamine hydrochloride, $\mathrm{N}$-[2-hydroxyethyl]piperazine- $\mathrm{N}$ '-2-ethanesulfonic acid] (HEPES), and trifluoroacetic acid (Sigma Chemical Co.,St.Louis, MO); Acidwashed carbon powder (Fluka Chemie AG, Buchs, Switzerland); Affi-Gel 10 Gel (Bio-Rad Laboratories). Liquid enzyme preparations (NOVO Nordisk, Bagsvaerd, Denmark) Flavourzyme 1000-L (aminopeptidase, EC 3.4.11.1) and Fungamyl 800-L ( $\alpha$-amylase, EC 3.2.1.1); Folate binding protein (FBP) (bovine milk), Cat. No. F0524 (Scripps, San Diego, CA).

(b) Folate standards. - Folic acid, 10-formylfolic acid (10-HCO-folic acid), (6R,S)5-formyl-5,6,7,8-tetrahydrofolic acid, calcium salt (5-HCO-H 4 folate), (6R,S)-5methyl-5,6,7,8-tetrahydrofolic acid, calcium salt $\left(5-\mathrm{CH}_{3}-\mathrm{H}_{4}\right.$ folate), $(6 \mathrm{R}, \mathrm{S}) 5,10-$ methenyl-5,6,7,8-tetrahydrofolic acid hydrochloride $\left(5,10-\mathrm{CH}^{+}-\mathrm{H}_{4}\right.$ folate), pteroyltri-g-L-glutamic acid (PteGlu $)_{3}$, (6R,S)-5,6,7,8-tetrahydrofolic acid trihydrochloride $\left(\mathrm{H}_{4}\right.$ folate) from B.Schircks Laboratories, Jona, Switzerland.

(c) Sodium dihydrogen phosphate solution (0.1 M).- Dissolve $13.8 \mathrm{~g}$ $\mathrm{NaH}_{2} \mathrm{PO}_{4} \cdot \mathrm{H}_{2} \mathrm{O}$ in $500 \mathrm{~mL}$ water, transfer to $1 \mathrm{~L}$ volumetric flask. Dilute to volume with water and mix.

(d) Dipotassium hydrogen phosphate solution (0.1 M). - Dissolve $17.4 \mathrm{~g} \mathrm{~K}_{2} \mathrm{HPO}_{4}$ in $500 \mathrm{~mL}$ water, transfer to $1 \mathrm{~L}$ volumetric flask. Dilute to volume with water and mix.

(e) Phosphate buffer (0.1M, pH 7).- Mix $50 \mathrm{~mL}$ of sodium dihydrogen phosphate solution, (c), with $80 \mathrm{~mL}$ dipotassium hydrogen phosphate solution, (d). Check $\mathrm{pH}$ and adjust when necessary to 7.0 with $\mathrm{KOH}(4 \mathrm{M})$ or $\mathrm{HCl}(4 \mathrm{M})$.

(f) Potassium hydroxide solution (600 g/L). - Dissolve $600 \mathrm{~g} \mathrm{KOH}$ in $500 \mathrm{~mL}$ water. Cool to room temperature and dilute to $1 \mathrm{~L}$ with water, and mix.

(g) Sodium borate solution (0.05 M, pH 9.3).- Degas ca $1.5 \mathrm{~L}$ water under reduced pressure to remove dissolved oxygen. Dissolve $19.07 \mathrm{~g} \mathrm{Na}_{2} \mathrm{~B}_{4} \mathrm{O}_{7} \cdot 10 \mathrm{H}_{2} \mathrm{O}$ in 500 $\mathrm{mL}$ boiled water. Transfer to $1 \mathrm{~L}$ volumetric flask. Dilute to volume with water 
and mix. Check pH and adjust when necessary to 9.3 with $\mathrm{KOH}(4 \mathrm{M})$ or $\mathrm{HCl}(4$ $M)$. Prepare on day of use.

(h) Sodium borate solution $(0.05 \mathrm{M})$ containing mercaptoethanol $(0.4 \% \mathrm{v} / \mathrm{v})$. Bring $0.4 \mathrm{~mL} 2$-mercaptoethanol into a $100 \mathrm{~mL}$ volumetric flask. Dilute to volume with sodium borate solution (g), and mix. Prepare on day of use

(i) Blank solution. - Bring $1.0 \mathrm{~mL}$ sodium borate solution $(0.05 \mathrm{M})$ containing 2mercaptoethanol $(0.4 \% \mathrm{v} / \mathrm{v}),(\mathrm{h})$, in a $100 \mathrm{~mL}$ volumetric flask. Dilute to the mark with phosphate buffer $0.1 \mathrm{M}, \mathrm{pH} 7.0$, (e). Prepare on day of use.

(j) Ascorbic acid solution (1\% m/v). - Dissolve $5 \mathrm{~g}$ ascorbic acid in $500 \mathrm{~mL}$ sodium borate solution, (g). Prepare fresh on day of use.

(k) $50 \mathrm{Mm}$ CHES- $50 \mathrm{mM}$ HEPES buffer.- Dissolve in ca $80 \mathrm{~mL}$ water: $1.192 \mathrm{~g}$ HEPES, $1.037 \mathrm{~g}$ CHES and $2 \mathrm{~g}$ ascorbic acid. Add $1.39 \mathrm{~mL} 2-$ mercaptoethanol. Bring $\mathrm{pH}$ to 7.85 with $\mathrm{KOH}$, (f). Transfer to $100 \mathrm{~mL}$ volumetric flask and dilute to volume with water. Prepare on day of use.

(l) Wash solution I: Phosphate buffer $(0.025 \mathrm{M}, \mathrm{pH} 7)$ containing $1 \mathrm{M} \mathrm{NaCl}$. Dilute $25 \mathrm{~mL}$ phosphate buffer, (e), to $100 \mathrm{~mL}$ with water. Check $\mathrm{pH}$ and adjust when necessary to 7 with $\mathrm{HCL}(4 \mathrm{M})$ or $\mathrm{KOH}(4 \mathrm{M})$. Dissolve $5.85 \mathrm{~g} \mathrm{NaCl}$ in $100 \mathrm{~mL}$ phosphate buffer $\mathrm{pH} 7$.

(m) Wash solution II: Phosphate buffer (0.025 M, pH 7). - Dilute $25 \mathrm{~mL}$ phosphate buffer, (e), to $100 \mathrm{~mL}$ with water. Check $\mathrm{pH}$ and adjust when necessary to 7 with $\mathrm{HCL}(4 \mathrm{M})$ or $\mathrm{KOH}(4 \mathrm{M})$.

(n) Elution solution: $0.02 \mathrm{M}$ Trifluoracetic acid-0.02 M dithioerytreitol.- Dissolve $308 \mathrm{mg}$ dithioerytreitol in ca $40 \mathrm{~mL}$ water. Add $153 \mu \mathrm{L}$ trifluoracetic acid. Dilute to $100 \mathrm{~mL}$ with water and mix.

(o) Ascorbic acid solution (25\%, w/v).- Dissolve $2.5 \mathrm{~g}$ ascorbic acid in $10 \mathrm{~mL}$ water. Prepare on day of use.

(p) Sodium hydrogen carbonate solution $(0.1 \mathrm{M}, \mathrm{pH} 6.5)$.- Dissolve $0.84 \mathrm{~g}$ $\mathrm{NaHCO}_{3}$ in $80 \mathrm{~mL}$ water. Adjust $\mathrm{pH}$ to 6.5 with $\mathrm{HCl}$ and dilute to $100 \mathrm{~mL}$ with water. Store in refrigerator untl use.

(q) Sodium acetate solution (0.01 M, pH 4.5).- Dissolve $82 \mathrm{mg}$ sodium acetate in $80 \mathrm{~mL}$ water. Adjust to $\mathrm{pH} 4.5$ with $\mathrm{HCl}$. Transfer to a $100 \mathrm{~mL}$ volumetric flask and dilute to volume with water. Store in refrigerator.

(r) Ethanolamine hydrochloride $\left(1 \mathrm{M}, \mathrm{pH}\right.$ 8):- Dissolve $6.1 \mathrm{~g} \mathrm{C}_{2} \mathrm{H}_{5} \mathrm{ONH}_{2} \cdot \mathrm{HCl}$ in 80 $\mathrm{mL}$ water. Bring to $\mathrm{pH} 8$ with $\mathrm{KOH}(4 \mathrm{M})$. Dilute to $100 \mathrm{~mL}$ with water. Store in refrigerator.

(s) Affinity Chromatography columns.- For preparation of 6 columns, bring $3 \mathrm{~mL}$ FBP ( $1 \mathrm{mg} \mathrm{FBP} / \mathrm{mL}$ ) with $9 \mathrm{~mL}$ cold $\mathrm{NaHCO}_{3},(\mathrm{p})$, in a $25 \mathrm{~mL}$ capped bottle. Store in refrigerator until combination with Affi-Gel 10. Shake vial with Affi-Gel 10. Transfer $12 \mathrm{~mL}$ slurry into a glass fritted funnel. Drain supernatant solvent and wash the gel with three bed volumes of cold sodium acetate, $(q)$. Use vacuum but do not dry the gel bed. Transfer moist gel cake to the cold FBP 
solution within $20 \mathrm{~min}$. Agitate sufficiently to make a uniform suspension. Continue gentle agitating overnight at $4^{\circ} \mathrm{C}$ and then add $1.2 \mathrm{~mL}$ ethanolamine solution, (r). Continue agitating at $4^{\circ} \mathrm{C}$ for $1 \mathrm{~h}$. Distribute the gel over 6 columns, (g). Wash 2 times with $5 \mathrm{~mL} \mathrm{NaHCO}$ solution, (p), and 2 times with $5 \mathrm{~mL}$ phosphate buffer, (e). When not in use, store columns at $4^{\circ} \mathrm{C}$ in phosphate buffer, $(e)$, containing $0.2 \%(w / v)$ sodium azide.

(t) Dialyzing buffer: $50 \mathrm{mM}$ CHES- $50 \mathrm{Mm}$ HEPES, $\mathrm{pH} 7.85$.- Dissolve $23.8 \mathrm{~g}$ HEPES, $20.7 \mathrm{~g}$ CHES, $40 \mathrm{~g}$ sodium ascorbate and $1.4 \mathrm{~mL}$ 2-mercaptoethanol in ca $1900 \mathrm{~mL}$ water. Adjust to $\mathrm{pH} 7.85$ with $\mathrm{KOH}$, (f), and Dilute to $2 \mathrm{~L}$ with water. Add $4 \mathrm{~g}$ of acid-washed carbon powder. Store in refrigerator until use.

(u) Rat plasma conjugase.- Fresh rat plasma was obtained from the local University animal laboratory. Collect rat blood in lithium heparin coated tubes and centrifuge for $15 \mathrm{~min}$ at $3000 \mathrm{~g}$. A possible commercial source for rat plasma is Pel-Freez Biologicals, Cat. No. 36142 (Rogers, AR). From the collected plasma, transfer $100 \mathrm{~mL}$ into dialyzing tubing and dialyze in $2 \mathrm{~L}$ dialyzing buffer, $(t)$, for 24 hours at $4^{\circ} \mathrm{C}$. Store dialyzed rat plasma in $0.5 \mathrm{~mL}$ portions for a maximum of 3 months at $-80^{\circ} \mathrm{C}$. Check activity of this plasma

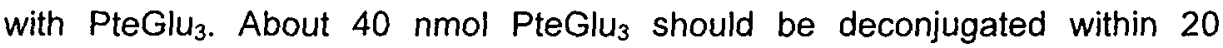
minutes at $37^{\circ} \mathrm{C}$.

(v) Mobile phase.-(1) A: Phosphate buffer (0.033 M, pH 2.1).- Pipet $4.45 \mathrm{~mL}$ phosphoric acid, (a), in a $2 \mathrm{~L}$ conical flask. Add ca $1900 \mathrm{~mL}$ water. Adjust to $\mathrm{pH}$ 2.1 with $\mathrm{KOH},(f)$. Transfer to a $2 \mathrm{~L}$ volumetric flask and dilute to the mark with water. (2) B: Acetonitrile.- Degas solutions.

(w) Folate standard solutions.- (1) Stock solutions (1 $\mathrm{mg} / \mathrm{mL}$ ).- Bring folate standards, (b), to room temperature. Dissolve by ultrasonic agitation, ca $10 \mathrm{mg}$ folic acid in $8 \mathrm{~mL}$ sodium borate solution, (h). Transfer into $10 \mathrm{~mL}$ volumetric flask, dilute to volume with borate solution, (h), and mix. Similarly, prepare stock solutions for $10-\mathrm{HCO}$-folic acid, $5-\mathrm{HCO}-\mathrm{H}_{4}$ folate, $5-\mathrm{CH}_{3}-\mathrm{H}_{4}$ folate, $5,10-$ $\mathrm{CH}^{+}-\mathrm{H}_{4}$ folate and $\mathrm{H}_{4}$ folate. (2) Standard working solutions $(10 \mu \mathrm{g} / \mathrm{mL})$.- Bring immediately $1.0 \mathrm{~mL}$ folate stock solution $(w)(1)$, into $100 \mathrm{~mL}$ volumetric flask containing $60 \mathrm{~mL}$ phosphate buffer, (e). Dilute to volume with phosphate buffer, (e), and mix. 5,10-Methenyl-THF is diluted in $0.01 \mathrm{M} \mathrm{HCL}$. Determine absorbance difference $\left(A-A_{0}\right)$ for each standard working solution within $5 \mathrm{~min}$, with spectrometer at suitable wavelengths. (Use settings given in table 1). $A$ is absorbance of standard solution and $A_{0}$ is absorbance of blank, (i). Record absorbance spectra between 200 and $400 \mathrm{~nm}$. Calculate concentration of each standard working solution. The blank for $5,10-\mathrm{CH}^{+}-\mathrm{H}_{4}$ folate is $0.01 \mathrm{M} \mathrm{HCl}$. Determine the absorbance for $5-\mathrm{CH}_{3}-\mathrm{H}_{4}$ folate also at $245 \mathrm{~nm}$. Beware that the calculated absorbance ratio $(290 \mathrm{~nm} / 245 \mathrm{~nm})$ does not exceed 3.3. Larger ratios indicate the presence of a dihydro derivate of $5-\mathrm{CH}_{3}-\mathrm{H}_{4}$ folate. (3). Standard working solutions for storage $(10 \mu \mathrm{g} / \mathrm{ml})$.-Immediately after 
preparation of each stock solution $(w)(1)$, pipet $2.0 \mathrm{~mL}$ into a $200 \mathrm{~mL}$ volumetric flask. Dilute to the mark with ascorbic acid solution, (j). Divide these solutions in $4 \mathrm{~mL}$ portions and store at $-80^{\circ} \mathrm{C}$. These solutions are stable for 3 months. (4). Calibration solutions.- Construct calibration curves with diluted standard working solutions $(w)(3)$. Pipet respectively 20,40,60,80 and 100 $\mu \mathrm{L} \mathrm{H}_{4}$ folate and $5-\mathrm{CH}_{3}-\mathrm{H}_{4}$ folate and $50,100,150,200$ and $250 \mu \mathrm{L} \mathrm{5-HCO-}$ $\mathrm{H}_{4}$ folate, folic acid, 10-HCO-folic acid in five $25 \mathrm{~mL}$ volumetric flasks. Accordingly, add to each flask $1 \mathrm{~mL}$ ascorbic acid solution, (0), $25 \mu \mathrm{L} 2-$ mercaptoethanol, (a), and $200 \mu \mathrm{L} \mathrm{KOH,} \mathrm{(f).} \mathrm{Dilute} \mathrm{to} \mathrm{volume} \mathrm{with} \mathrm{elution}$ solution, $(\mathrm{n})$. Concentration range of folate standards is $8-100 \mathrm{ng} / \mathrm{mL}$. Prepare solutions fresh on day of use.

\section{Materials}

Materials analyzed in this study consisted of a lyophilized mixed vegetable sample (sweet corn-thinned tomatoes-carrot $10+1+1 \mathrm{~m} / \mathrm{m} / \mathrm{m}$ ); Certified Reference Material [CRM] 485), lyophilized pig liver (CRM 487), milk powder enriched with folic acid (CRM 421), and whole-meal flour (CRM 121). Milk powder was a spray-dried powder from cow's milk. Three materials are candidate CRMs: CRM 485, CRM 487 and CRM 121. CRM 421 is already CRM.

The Institute for Reference Materials and Measurement (IRMM) in Geel, Belgium, provided these samples.

Table 1. Molar absorption coefficients $(\varepsilon)^{\mathrm{a}}$, molar mass $(\mathrm{M})$, and maximum wavelengths $\left(\lambda_{\max }\right)$ for folates.

\begin{tabular}{lcccc}
\hline Folate vitamer & $\mathrm{pH}$ & $\mathrm{M}$ & $\lambda_{\max , \mathrm{nm}}$ & $\begin{array}{c}\varepsilon_{,} \\
\mu \mathrm{mol} / \mathrm{mL} \times \mathrm{cm}\end{array}$ \\
\hline folic acid & 7 & 441.4 & 283 & 27.6 \\
$5-\mathrm{CH}_{3}-\mathrm{H}_{4}$ folate & 7 & 457.4 & 290 & 31.7 \\
$\mathrm{H}_{4}$ folate & 7 & 445.4 & 297 & 29.1 \\
$5-\mathrm{HCO}-\mathrm{H}_{4}$ folate & 7 & 473.5 & 285 & 37.2 \\
$10-\mathrm{HCO}_{\text {folic acid }}$ & 7 & 469.4 & 269 & 20.9 \\
$5,10-\mathrm{CH}^{+}-\mathrm{H}_{4}$ folate & 2 & 456.4 & 352 & 25.0 \\
\hline
\end{tabular}

Data from Blakley (1969).

\section{Extraction}

Perform all samples and standard preparations under subdued light. Avoid contact with air and operate under nitrogen atmosphere when possible. Suspend milk powder by mixing $50.00 \mathrm{~g}$ sample with $50.00 \mathrm{~g}$ water at $37^{\circ} \mathrm{C}$ prior to analysis. Accurately weigh into separate $100 \mathrm{~mL}$ beaker mixed vegetables $(1.50 \mathrm{~g})$, pig liver $(0.50 \mathrm{~g})$, milk powder slurry $(4.00 \mathrm{~g})$, and whole-meal flour $(5.00 \mathrm{~g})$. Add ca $45 \mathrm{~mL}$ 
CHES-HEPES buffer, (k), and homogenize with Ultra Turrax apparatus. Cover beaker and place in boiling water bath for $10 \mathrm{~min}$. Swirl extracts occasionally during heat treatment. Homogenize again (Ultra Turrax) and cool immediately in water bath at $0^{\circ} \mathrm{C}$.

Adjust to $\mathrm{pH} 7$ with $\mathrm{HCl}(4 \mathrm{M})$ and weigh each extract. Transfer for each material the following mass portions into three $10 \mathrm{~mL}$ centrifuge tubes for deconjugation: mixed vegetables, $4.00 \mathrm{~g}$; pig liver, $2.00 \mathrm{~g}$; milk powder, $5.00 \mathrm{~g}$; and whole-meal flour, $8.00 \mathrm{~g}$. The folate content in each tube should not exceed $500 \mathrm{ng}$. For each material, add nothing to the first tube (treatment 1 ), add $0.5 \mathrm{~mL}$ thawed rat plasma conjugase, $(u)$, to the second tube (treatment 2 ), and add $0.5 \mathrm{~mL}$ thawed rat plasma conjugase, (u), along with $50 \mu \mathrm{L}$ of Fungamyl, (a), and $50 \mu \mathrm{L}$ of Flavourzyme, (a), to the third tube (treatment 3). For the wholemeal flour extract, perform 2 treatments. Add to the first tube $50 \mu \mathrm{L}$ of Fungamyl, (a), and $50 \mu \mathrm{L}$ of Flavourzyme, (a), (treatment 4), and add to the second tube thawed rat plasma conjugase, Fungamyl and Flavourzyme as mentioned for treatment 3 above. Mix and incubate all tubes for 4 hours at $37^{\circ} \mathrm{C}$ in shaking water bath. Stop deconjugation by keeping tubes for $5 \mathrm{~min}$ in boiling water bath. Cool immediately in ice bath and centrifuge for $20 \mathrm{~min}$ at $5000 \mathrm{xg}$ and $2-4^{\circ} \mathrm{C}$. Transfer supernatant into a clean tube, resuspend residue in ca $2 \mathrm{~mL}$ CHES-HEPES buffer, (k), and centrifuge for $20 \mathrm{~min}$ at $5,000 \mathrm{~g}$ and $2-4^{\circ} \mathrm{C}$. Combine supernatants and store at $80^{\circ} \mathrm{C}$ until cleanup (usually within a few days).

\section{Affinity chromatography}

Equilibrate FBP column, (s), by rinsing with $5 \mathrm{~mL}$ phosphate buffer, (e). Don't allow column to go dry. Transfer thawed sample extracts into FBP columns and elute at flow rate of ca $0.3 \mathrm{~mL} /$ minute. Apply light vacuum if necessary. Rinse with $5 \mathrm{~mL}$ wash solution I, (I), followed by $5 \mathrm{~mL}$ wash solution II, (m). Elute folates with 4.6 $\mathrm{mL}$ elution solution, $(\mathbf{n})$, in tube containing $0.2 \mathrm{~mL}$ ascorbic acid solution, (o), $40 \mu \mathrm{L}$ $\mathrm{KOH},(f)$, and $5 \mu \mathrm{L}$ 2-mercaptoethanol, (a). Transfer to $5 \mathrm{~mL}$ volumetric flask and fill to the mark with elution solution, (n). Proceed with LC analysis.

\section{LC Analysis}

Prior to analysis, equilibrate LC system with a mixture of $95 \%$ phosphate buffer, (v) (1), and $5 \%$ acetonitrile, (v)(2). Adjust flow rate to $0.8 \mathrm{~mL} /$ minute, inject $100 \mu \mathrm{L}$ sample extract or working standard solutions $(w)(4)$, and subsequently run gradient program. Start gradient with a mixture of $95 \%$ phosphate buffer and $5 \%$ acetonitrile. After $3 \mathrm{~min}$, change acetonitrile proportion to $10 \%$ within $10 \mathrm{~min}$. Between 10 and $12 \mathrm{~min}$ adapt the acetonitrile proportion to $5 \%$ and to $10 \%$ after $12.5 \mathrm{~min}$. Between 13 en $14 \mathrm{~min}$, change the mobile phase composition to $95 \%$ phosphate buffer and $5 \%$ acetonitrile. Regenerate column after $26 \mathrm{~min}$ by modifying the eluant composition to contain phosphate buffer and acetonitrile at 
respective volume fractions of 0.7 and 0.3 within $1 \mathrm{~min}$. Maintain composition until 30 min and change again to $95 \%$ phosphate buffer and $5 \%$ acetonitrile within 0.5 $\mathrm{min}$. Use a flow rate of $0.8 \mathrm{~mL} / \mathrm{min}$. Time between 2 consecutive injections is 40 $\min$.

Construct linear regression plot of standard curve for each vitamer and calculate concentration in sample. Correct for blanks from rat plasma, Flavourzyme, and Fungamyl.

\section{RESULTS AND DISCUSSION}

The method is suitable for determining folates in various food matrixes. The LC separation of individual folates is satisfactory for standards and folates in various food matrixes. Antioxidants and degradation products like paraaminobenzoylglutamate do not interfere with several folate vitamers. Figure 1 illustrates separation of the most important folates determined with the method using UV and fluorescence detection. With this procedure $5,10-\mathrm{CH}^{+}-\mathrm{H}_{4}$ folate and $\mathrm{H}_{2}$ folate are also separated. However 10 -methylene- $\mathrm{H}_{4}$ folate is not separated from $\mathrm{H}_{4}$ folate.

Stabilities of folate stock solutions were tested regularly by injecting standard working solutions into the LC system. Concentrations were calculated and compared with those of freshly prepared stock solutions. It was found that folate stock solutions should not be used after 12 weeks of storage at $-80^{\circ} \mathrm{C}$.

The response of the LC system was linear for the concentration range $0-100 \mathrm{ng} /$ $\mathrm{mL}$ for all folates (correlation coefficients $>0.999$ ). Detection limits (signal to noise ratio $\geq 3$ ) were $7 \mathrm{pg} / \mathrm{mL}$ for $\mathrm{H}_{4}$ folate and $5-\mathrm{CH}_{3}-\mathrm{H}_{4}$ folate, $59 \mathrm{pg} / \mathrm{mL}$ for $10-\mathrm{HCO}$-folic acid, and $1 \mathrm{ng} / \mathrm{mL}$ for $5-\mathrm{HCO}_{\mathrm{C}} \mathrm{H}_{4}$ folate and folic acid.

Folates are extracted from food matrixes by several procedures. Gregory et al. (1990) mentioned the superiority of the extraction buffer used by Wilson and Horne (Wilson \& Horne 1984, Wilson \& Horne 1986). Vahteristo et al. (1996) and Pfeiffer et al. (1997) described the excellent stability of folates when extracted with a combination of ascorbic acid and 2-mercaptoethanol. Vahteristo et al. (1996) investigated the procedure described by Gregory (1984) by comparing a $1 \mathrm{~h}$ extraction at $\mathrm{pH} 4.9$ with a 10 min extraction at $\mathrm{pH}$ 6.0. The latter resulted in higher folate contents. Higher folate levels, especially for $\mathrm{H}_{4}$ folate in pig liver, were obtained in this study when compared with the Vahteristo et al (1996) method, probably because of the more neutral $\mathrm{pH}$ conditions. De Souza \& Eitenmiller (1990) and Martin et al. (1990) used protease and $\alpha$-amylase to obtain a more complete extraction of folates from food matrixes. Tamura et al. (1997) stated that all food folate values in tables should be revised by using enzyme treatments to accurately establish food folate content. Pfeiffer et al. (1997) applied protease and $\alpha$-amylase to folate assays of cereal and grain products. 

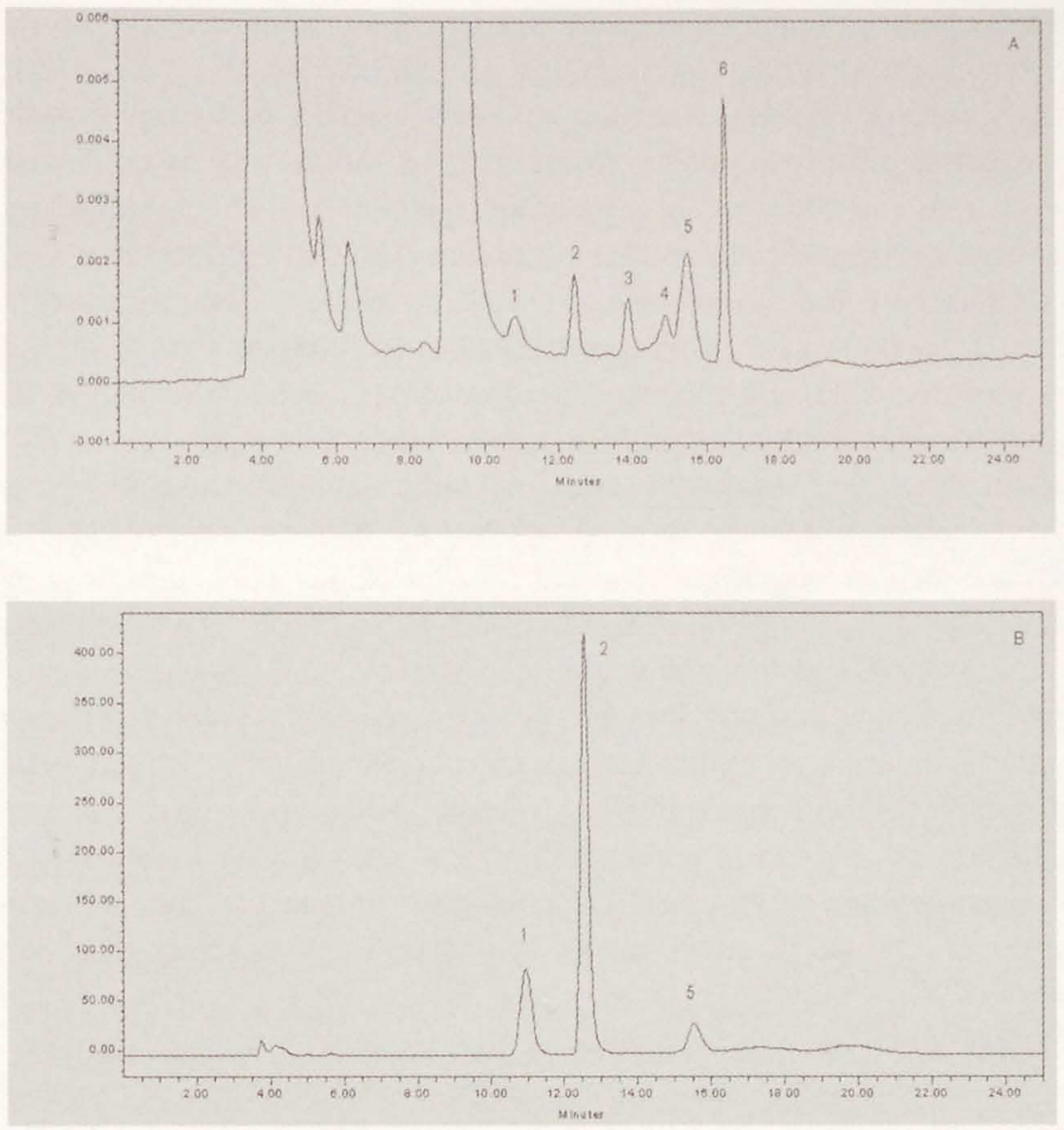

Figure 1. Chromatograms of folates in a standard mixture detected by UV $(280 \mathrm{~nm})$ for $A$ and by fluorescence $\left(\lambda_{e x}=280 \mathrm{~nm}, \lambda_{e m}=359 \mathrm{~nm}\right)$ for $B$. Concentrations injected: $\mathrm{H}_{4}$ folate $\pm 2 \mathrm{ng}, 5-\mathrm{CH}_{3}-\mathrm{H}_{4}$ folate $\pm 6 \mathrm{ng}$; folic acid $\pm 13 \mathrm{ng}, 5-\mathrm{HCO}-\mathrm{H}_{4}$ folate $\pm 9 \mathrm{ng}, 10-$ $\mathrm{HCO}$-folic acid $\pm 4 \mathrm{ng}$, and $10-\mathrm{HCO}-\mathrm{H}_{2}$ folate, $\pm 18 \mathrm{ng}$. Peaks: $1=\mathrm{H}_{4}$ folate, $2=5-\mathrm{CH}_{3}$ $\mathrm{H}_{4}$ folate, $3=10-\mathrm{HCO}-\mathrm{H}_{2}$ folate, $4=10-\mathrm{HCO}$-folic acid, $5=5-\mathrm{HCO}-\mathrm{H}_{4}$ folate, $6=$ folic acid.

In this study, 2 liquid enzyme preparations were used because of their coherent enzyme activities at different $\mathrm{pHs}$. A combination of Fungamyl, Flavourzyme, and rat plasma conjugase used for $4 \mathrm{~h}$ at $37^{\circ} \mathrm{C}$ had no effect on the deconjugation of

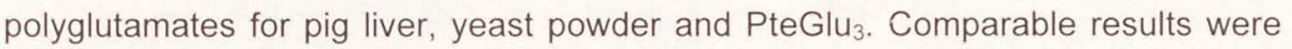
obtained for the same samples treated with rat plasma conjugase and the combination of rat plasma conjugase, Fungamyl and Flavourzyme. No starch was demonstrable after incubation of a potato sample with the 3 enzymes. For milk, the procedure delivered a clear sample after incubation with the combined enzymes.

For deconjugation of polyglutamates, hog kidney conjugase and rat plasma conjugase are commonly used in folate analysis. Application of hog kidney conjugase at $\mathrm{pH} 4.9$ resulted in substantial losses of folates (Goli \& Vanderslice, 
1992). Deconjugation at $\mathrm{pH}$ 6-7 resulted in improvements of analytical findings. Rat plasma conjugase has an optimum $\mathrm{pH}$ of 6.2-7.5 (Horne et al. 1981) and, therefore, is appropriate for deconjugation. A study was performed to determine kinetic parameters for both hog kidney conjugase and rat plasma conjugase. Hog kidney conjugase was purified according to a method described by Gregory et al. (1984). Fresh rat plasma was purified according to a method described by Pfeiffer et al. (1997). The reaction mixture for hog kidney conjugase consisted of $75 \mathrm{mM}$ $\mathrm{K}_{2} \mathrm{HPO}_{4}, 1 \%$ ascorbic acid $(\mathrm{w} / \mathrm{v})$ and $0.1 \%(\mathrm{v} / \mathrm{v})$ 2-mercaptoethanol, $\mathrm{pH}$ 4.5. The reaction mixture for rat plasma conjugase consisted of $50 \mathrm{mM}$ HEPES, $50 \mathrm{mM}$ CHES, $2 \%$ ascorbic acid (w/v) and $0.2 \mathrm{M}$ 2-mercaptoethanol, $\mathrm{pH}$ 7.5. PteGlu 3 was used as substrate. The Lineweaver-Burk method for calculating kinetic parameters yielded $\mathrm{K}_{\mathrm{m}}$-values of 2.0 and $2.3 \mu \mathrm{M}$ PteGlu $\mathrm{H}_{3}$ for hog kidney conjugase and rat plasma conjugase, respectively. The $K_{m}$ for hog kidney conjugase was in good agreement with results of Engelhardt and Gregory (1990), who calculated a $K_{m}$ value of 2.6. The findings show that hog kidney conjugase and rat plasma conjugase have comparable affinities to polyglutamyl folates. Along with the higher folate results determined during neutral $\mathrm{pH}$ conditions, they support use of rat plasma conjugase for deconjugation. $V_{\max }$ for hog kidney conjugase was $0.3 \mathrm{nmol} /$ (60 $\mu \mathrm{L}$ conjugase preparation $\times \mathrm{min}$ ). $\mathrm{V}_{\max }$ for rat plasma conjugase was $0.3 \mathrm{nmol} /$ (100 $\mu \mathrm{L}$ plasma $\times \mathrm{min}$ ). Every batch of conjugase preparation should be checked for activity with PteGlu $\mathrm{Cl}_{3}$ as substrate. No loss of activity was shown after 3 months storage at $-80^{\circ} \mathrm{C}$.

Sample extracts have to be purified and/or concentrated because many foods have low folate contents. Extracts may contain many interfering compounds with identical chemical and/or chromatographical properties. Several papers describe use of anion-exchange purification alone or, in some cases combined with solidphase extraction (SPE) to concentrate folates (Gregory et al. 1984, Vahteristo et al. 1996, Gounelle et al. 1989, White 1990, Gauch et al. 1993). We initially tested a strong-anion-exchange SPE procedure in this study.

Müller (1993) stated that LC is not the right technique for determining folates in cereal-grain food products because the presence of many interfering compounds from samples resulting in misinterpretations. Pfeiffer et al. (1997) used affinity chromatography for cleanup and concentration of cereal grain products. However, the described preparation of FBP is labor-intensive. Commercial FBP proved to be a success and made the procedure more applicable under routine conditions.

Affi-Gel 10 with a slight negative charge was a suitable binder for FBP. To maximize coupling, FBP was dissolved in a solution with a pH lower than the $\mathrm{pl}$ of FBP. Iwai et al. (1983) and Svendsen et al. (1979) reported isoelectric points ranging from 6.8 to 8.5 for FBP from bovine milk. A pH of 6.5 was selected for the overnight coupling reaction solution at $4^{\circ} \mathrm{C}$. Remaining coupling groups were blocked with ethanolamine. The actual binding capacity was estimated by 
overloading the column with folic acid stock solution. Retained folic acid was eluted with $5 \mathrm{~mL}$ elution solution, and the mean binding capacity of $18.5 \mathrm{nmol} /$ column was determined. Sample folate loading should not exceed $25 \%$ of the binding capacity because of low 5-HCO-H $\mathrm{H}_{4}$ folate recoveries (Pfeiffer et al. 1997, Selhub 1989). After 6 samples (18 extracts) had been run, the binding capacity of a column decreased to $7.8 \mathrm{nmol} /$ column ( $58 \%$ reduction).

The method was validated by application to analysis of folates in 4 CRMs $(N=10)$. Results are presented in Table 2. Samples represented the most important folate sources in human food and foodstuffs: pig liver, milk powder (enriched with folic acid), mixed vegetables and whole-meal flour. To estimate monoglutamates, samples were analyzed without addition of any enzymes (treatment 1). Folate concentrations were quantitated after addition of rat plasma conjugase to establish the sum of mono- and polyglutamates (treatment 2). Total folate concentrations were determined after treatment with rat plasma conjugase and with Fungamyl and Flavourzyme (treatment 3).

For whole-meal flour extracts, 2 treatments were performed. One was similar to treatment 3 , and the other involved treatment with Flavourzyme and Fungamyl only (treatment 4 ) to quantify folate monoglutamates. Recoveries were determined by spiking samples before extraction with different standards at various folate levels (Table 3). Quantification of recoveries was performed after application of rat plasma conjugase, Flavourzyme and Fungamyl.

Optimal conditions for $\mathrm{pH}$, deconjugation time, and conjugase concentration were investigated. To check the deconjugation, an amount of PteGlu 3 was added prior to deconjugation of all 4 validated matrices. Deconjugation was complete in 4 $h$ at $37^{\circ} \mathrm{C}$, revealing the absence of an inhibitor impact on the deconjugation process.

Folates were quantitated according to external calibration standards. Recoveries of standards were near $100 \%$, except for $\mathrm{H}_{4}$ folate. Some $\mathrm{H}_{4}$ folate losses occurred during affinity chromatography. All $\mathrm{H}_{4}$ folate values reported here were corrected for a recovery value of $69 \%[\mathrm{~N}=5$, s (standard deviation) $=6.7 \%]$ from standard $\mathrm{H}_{4}$ folate.

Typical fluorescence and UV chromatograms are shown in figure 2. $\mathrm{H}_{4}$ folate, 5$\mathrm{CH}_{3}-\mathrm{H}_{4}$ folate and $10-\mathrm{HCO}$-folic acid were quantitated by fluorescence detection, whereas folic acid and $5-\mathrm{HCO}-\mathrm{H}_{4}$ folate were quantitated from UV chromatograms and confirmed by DAD. 


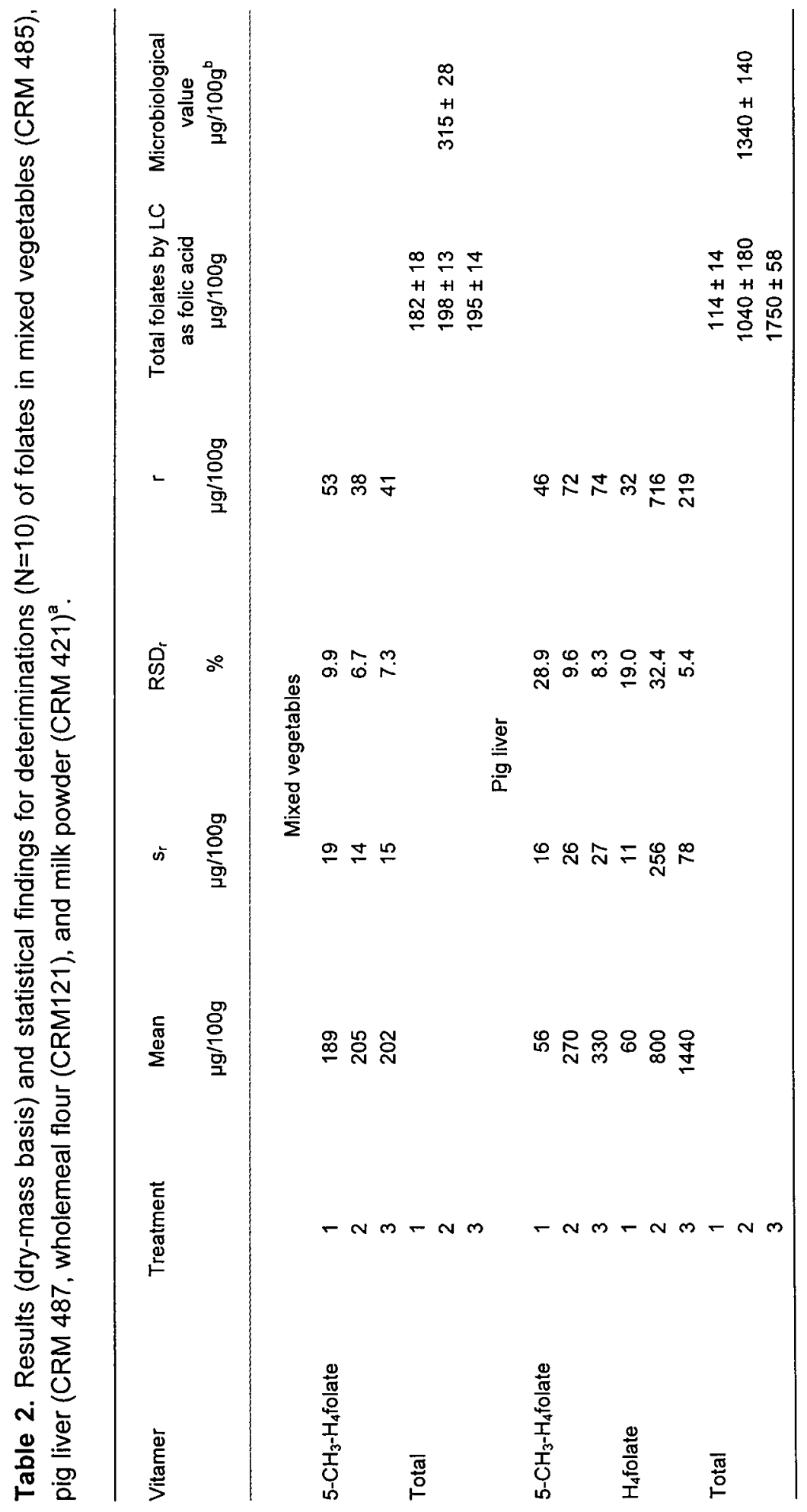




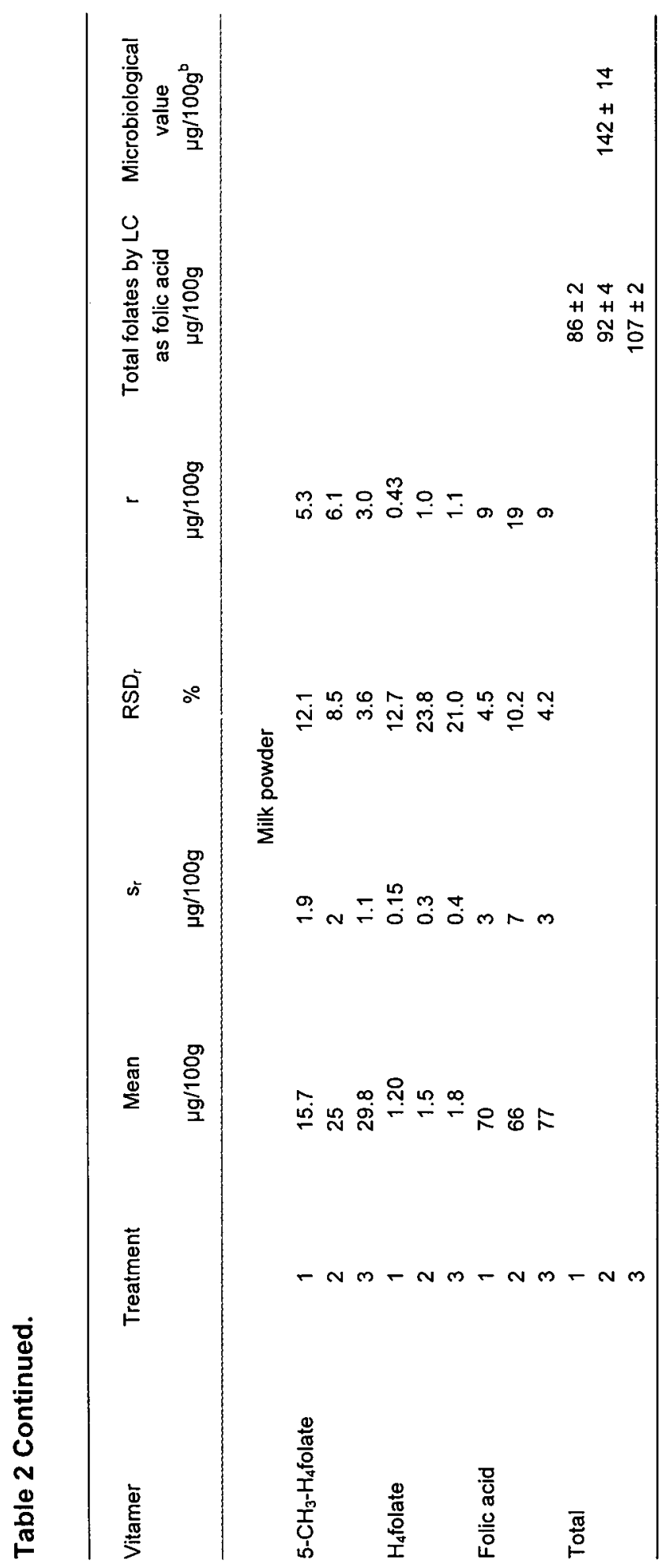




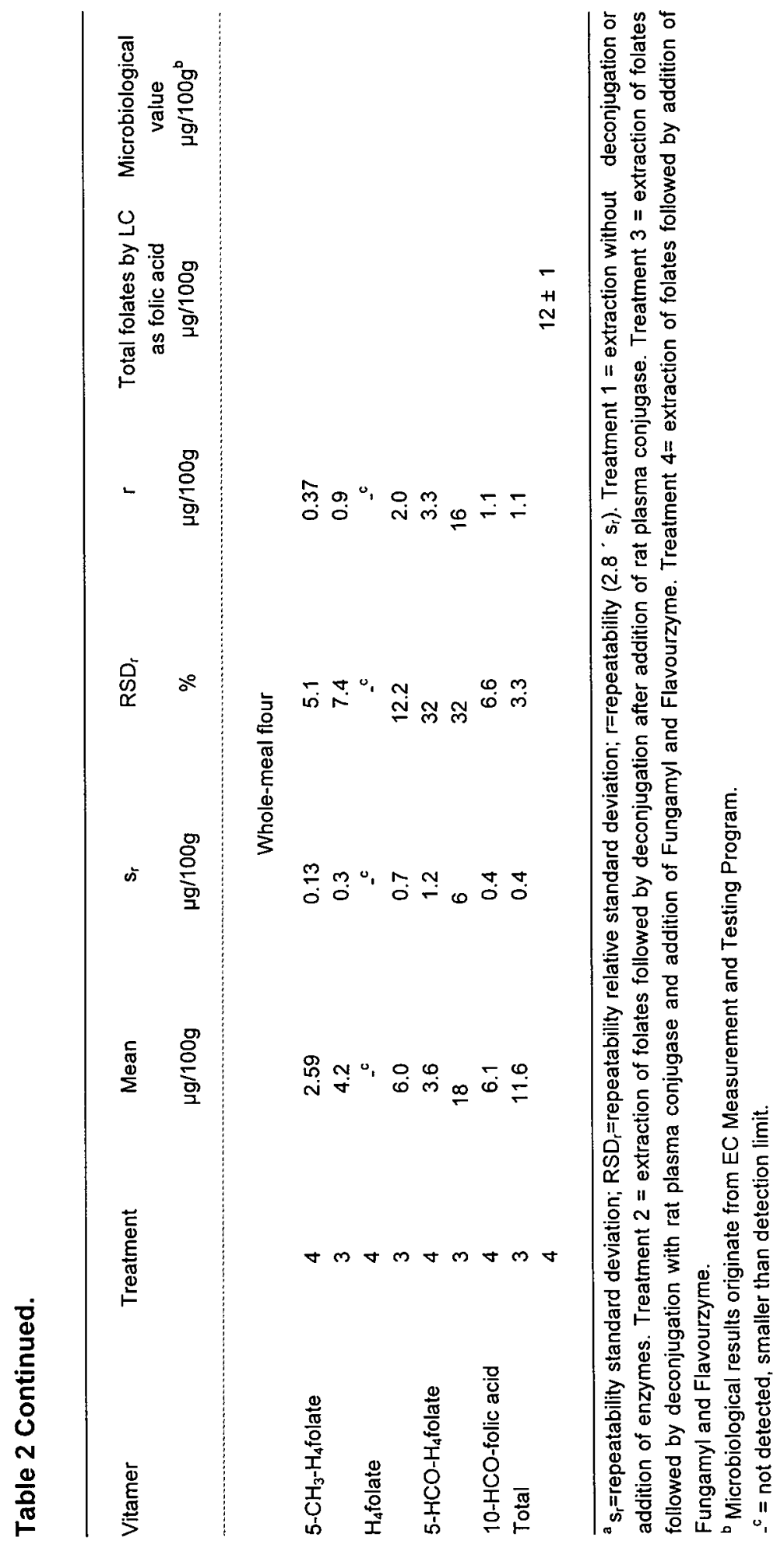


Table 3. Recovery of folates $(\mathrm{N}=10)^{\mathrm{a}}$.

\begin{tabular}{lcccc}
\hline Vitamer & $\begin{array}{c}\text { Amount in sample } \\
\mathrm{mg} / 100 \mathrm{~g}\end{array}$ & $\begin{array}{c}\text { Spiked, } \\
\mathrm{mg} / 100 \mathrm{~g}\end{array}$ & $\begin{array}{c}\text { Found, } \\
\mathrm{mg} / 100 \mathrm{~g}\end{array}$ & $\begin{array}{c}\text { Recovery, } \\
\%\end{array}$ \\
\hline & & Mixed vegetables & & \\
$5-\mathrm{CH}_{3}-\mathrm{H}_{4}$ folate & 202 & 172 & 356 & $90 \pm 9$ \\
& & Pig liver & & $109 \pm 12$ \\
$5-\mathrm{CH}_{3}-\mathrm{H}_{4}$ folate & 330 & 283 & 641 & $88 \pm 16$ \\
$\mathrm{H}_{4}$ folate & 1440 & 820 & 2161 & $85 \pm 10$ \\
& & Milk powder & & $90 \pm 12$ \\
$5-\mathrm{CH}_{3}-\mathrm{H}_{4}$ folate & 29.8 & 25.5 & 51.7 & 140 \\
Folic acid & 77 & 70 & & $76 \pm 12$ \\
& 18 & Wholemeal flour & 63 & $73 \pm 14$ \\
$5-\mathrm{HCO}-\mathrm{H}_{4}$ folat & 11.6 & 60 & 16.4 & \\
$10-\mathrm{HCO}$-folic acid & & 6.7 & & \\
\hline
\end{tabular}

${ }^{a}$ Results are on dry-mass basis.

Results were examined for outliers by the Grubb's test at the $p=0.05$ level of significance. One outlier was found for $\mathrm{H}_{4}$ folate in milk powder (treatment 1), 5$\mathrm{CH}_{3}-\mathrm{H}_{4}$ folate in milk powder (treatment 3), 10-HCO-folic acid in whole-meal flour (treatment 3) and one for $5-\mathrm{CH}_{3}-\mathrm{H}_{4}$ folate in whole-meal flour (treatment 4). Repeatability relative standard deviations $\left(R \mathrm{RD}_{r}\right)$ were lowest for treatment 3 , varying from 3.3 to $21.0 \%$ (concentration range, $1.8-1440 \mu \mathrm{g} / 100 \mathrm{~g}$ ). These values are acceptable for the levels studied according to the International Union of Pure and Applied Chemistry (1989) Harmonized Protocol (Pocklington, 1990) and AOAC's Peer-Verified Methods Program (1993), which recommend acceptable within-laboratory method performance $\left(R S D_{r}\right)$ ranges from $1 / 2$ to $2 / 3$ of the predicted reproducibility relative standard deviation $\left(R S D_{R}\right)$ for the levels of interest. One exception is the $\mathrm{RSD}_{\mathrm{r}}$ value of $32 \%$ for $5-\mathrm{HCO}-\mathrm{H}_{4}$ folate in whole-meal flour (treatment 3 ). The value is high, probably because of the relatively low UV absorbance of $5-\mathrm{HCO}_{-} \mathrm{H}_{4}$ folate. The $\mathrm{RSD}_{\mathrm{r}}$ value is acceptable when standard deviations of each vitamer were pooled, yielding 1 standard deviation for total amount of folates in whole-meal flour. For other treatments 1,2 and 4, all RSDr values were acceptable except those for $5-\mathrm{CH}_{3}-\mathrm{H}_{4}$ folate and $\mathrm{H}_{4}$ folate in pig liver (treatment 1) and for $\mathrm{H}_{4}$ folate in Pig Liver (treatment 2). These high variations may have been caused by high concentrations of matrix-bound folates. 

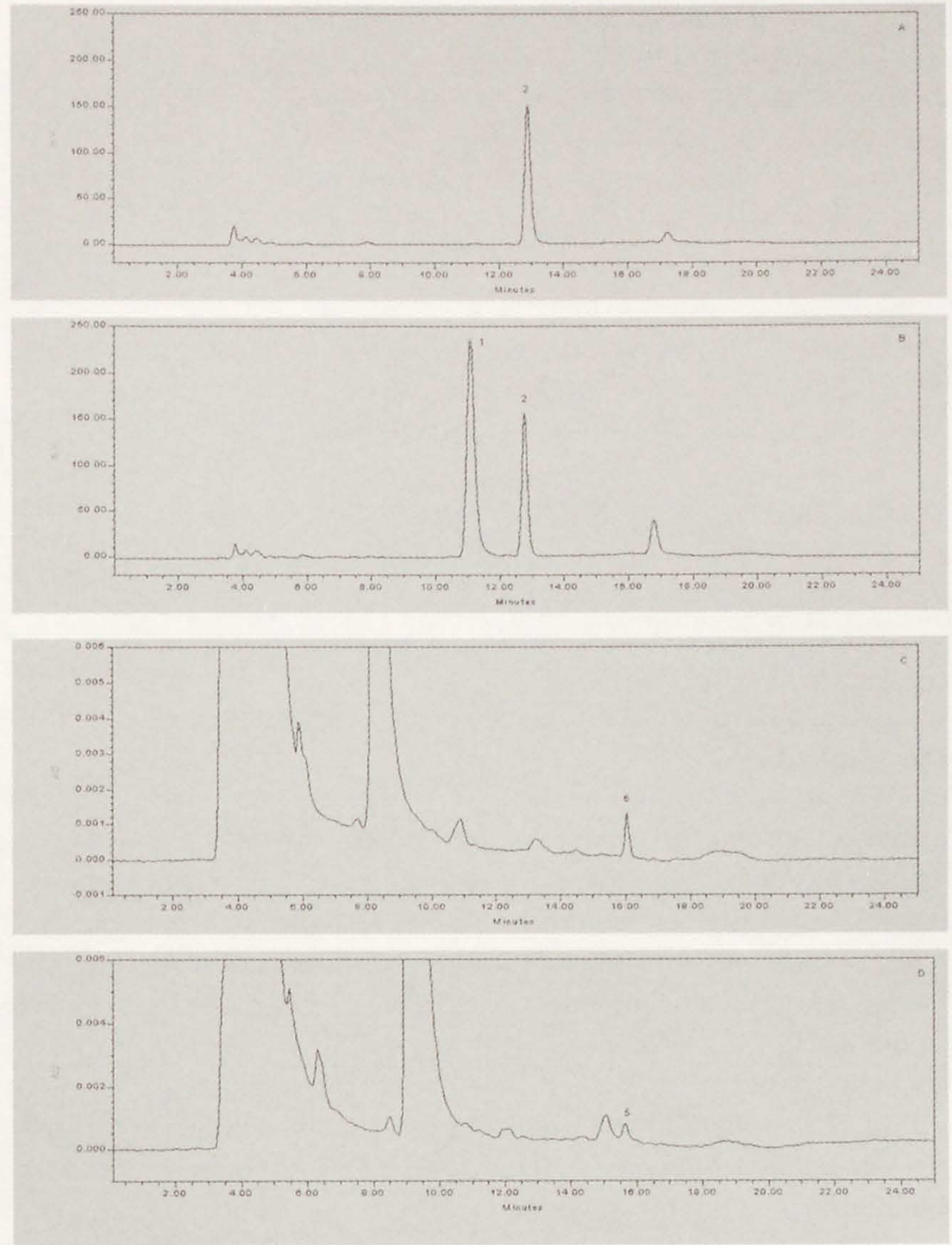

Figure 2. Chromatograms of folates detected by fluorescence $\left(\lambda_{\mathrm{ex}}=280 \mathrm{~nm}, \lambda_{\mathrm{em}}=359\right.$ $\mathrm{nm}$; samples $A$ and $B)$ and UV $\left(280 \mathrm{~nm}\right.$; samples $C$ and D). Peaks: $1=\mathrm{H}_{4}$ folate, $2=5$ $\mathrm{CH}_{3}-\mathrm{H}_{4}$ folate, 3=10- $\mathrm{HCO}-\mathrm{H}_{2}$ folate, $4=10-\mathrm{HCO}$-folic acid, 5=5- $\mathrm{HCO}-\mathrm{H}_{4}$ folate, $6=$ folic acid Samples: $A=$ mixed vegetables, $B=$ pig liver,$C=$ milk powder,$D=$ whole-meal flour.

Mean standard recoveries for folates added to mixed vegetables, pig liver, milk powder and whole-meal flour, ranged from 73 to $109 \%$. The acceptable recovery range for the levels determined is $80-110 \%$, according to the AOAC Peer-Verified Methods Program (1993).

Samples also were analyzed in intercomparison studies organized by the Institute of Food Research (Norwich, UK) under the European Commission 
Measurement and Testing Program. Fifteen participants assayed samples using their individual microbiological method with $\mathrm{L}$. rhamnosus var. casei. The $\mathrm{pH}$ of the media for microbiological growth was 6.2. Microbiological results of this collaborative study are also summarized in table 2 (Finglas et al. 1999a). A few participants used protease or amylase in sample pretreatment. Participants in the EC study were encouraged to include an $\alpha$-amylase treatment only for the wholemeal flour sample (Finglas et al. 1999b). Treatment with Flavourzyme and Fungamyl in the present study resulted in $50 \%$ higher folates in pig liver and $17 \%$ higher folates in milk powder (treatment 3 ). The vitamer that caused the increase in pig liver was mainly $\mathrm{H}_{4}$ folate.

It is difficult to compare microbiological results from the EC study and the present LC values for the 4 materials because sample pretreatments and quantitations were different. Microbiological results were therefore used as guide values for comparison of LC results of treatment 2. Total folates in the 4 materials analyzed in the present study were $20-35 \%$ lower than microbiological results. It was not evident that Flavourzyme and Fungamyl treatment resulted in higher values of folates in whole-meal flour analyzed by LC. Untreated whole-meal flour extracts could not be applied onto affinity chromatography columns because of their viscosity.

Three Participants assayed CRMs by LC for $5-\mathrm{CH}_{3}-\mathrm{H}_{4}$ folate (Finglas et al 1999a, 1999b) and obtained the following results: mixed vegetables, $214 \pm 42$ $\mu \mathrm{g} / 100 \mathrm{~g}$; pig liver, 260 (190-380) $\mu \mathrm{g} / 100 \mathrm{~g}$; milk powder, $25.0 \pm 1.4 \mu \mathrm{g} / 100 \mathrm{~g}$; wholemeal flour, 4 (3-8) $\mu \mathrm{g} / 100 \mathrm{~g}$. Samples were not treated with protease or amylase. These results are in good agreement with data from the present study (treatment 2).

With the described LC method (treatment 3), the exact amount of folic acid added to the milk powder sample ( $75 \mu \mathrm{g} / 100 \mathrm{~g}$ wet mass) was established.

No $10-\mathrm{HCO}-\mathrm{H}_{2}$ folate or $5,10-\mathrm{CH}^{+}-\mathrm{H}_{4}$ folate were found in the samples analyzed. Pfeiffer et al. (1997) determined $10-\mathrm{HCO}-\mathrm{H}_{2}$ folate in bread, which is probably produced during processing. With the described procedure, it is not possible to determine 10 -formyltetrahydrofolic acid $\left(10-\mathrm{HCO}-\mathrm{H}_{4}\right.$ folate) because this vitamer is converted to $5-\mathrm{HCO}-\mathrm{H}_{4}$ folate acid during heat treatment (Pfeiffer et al. 1994), or modified to $5,10-\mathrm{CH}^{+}-\mathrm{H}_{4}$ folate because of the low pH of the mobile phase (Pfeiffer et al. 1997). Therefore $10-\mathrm{HCO}-\mathrm{H}_{4}$ folate might be quantified indirectly when present.

The procedure determines folates in vegetables, milk powder, liver and flour with satisfactory, reliable, and reproducible results. Good estimates of monoglutamates, polyglutamates and matrix-bound folates in these matrixes can be made. To determine total folate contents, a combined treatment of the food extract with rat plasma conjugase, amylase and protease is recommended. The method is suitable for surveying vegetables, milk powder, liver and flour for folates. 


\section{ACKNOWLEDGEMENTS}

I thank J. Pauwels from the Institute for Reference Materials and Measurements, Geel, Belgium, for providing the mixed vegetables, milk powder, pig liver and whole-meal flour samples. I am also grateful for some methodological improvements, which can be attributed to participation in a project under the European Union's Standards, Measurements and Testing Program (1989-1998).

Thanks to C.H.I. Florisson and J.H.M. Linssen for their technical assistance and to P.R. Beljaars and H.H.S. Roomans (Inspectorate for Health Protection, Maastricht, The Netherlands) and P.M. Finglas (Institute of Food Research, Norwich, UK) for critically reading the draft and providing valuable comments.

\section{REFERENCES}

AOAC INTERNATIONAL, Peer-Verified Methods Program. Manual on Policies and Procedures. AOAC INTERNATIONAL, Arlington, VA, 1993.

Blakley RL. The Biochemistry of Folic Acid and Related Pteridines. In Frontiers of Biology. North Holland Publishing Company, Amsterdam 1969:92-4.

Boushy CJ, Beresford SAA, Omen GS, Motulsky AG. A quantative assessment of plasma homocysteine as a risk factor for vascular disease. Probable benefits of increasing folic acid intakes. J Am Med Assoc 1995; 274:1049-57.

Czeizel AE, Dudás I. Prevention of the first occurence of neural tube defects by periconceptional vitamin supplementation. N Engl J Med 1992; 327: 1832-5.

de Bree $A$, van Dusseldorp $M$, Brouwer $1 A$, van het Hof $K H$, Steegers-Theunissen RPM. Folate intake in Europe: recommended, actual and desired intake. Eur J Clin Nutr 1997;51:643-60.

DeSouza S, Eitenmiller R. Effects of different enzyme treatments on extraction of total folate from various foods prior to microbiological assay and radioassay. J Micronutr Anal 1990;7:37-57.

Engelhardt E, Gregory JF III. Adequacy of enzymatic deconjugation in quantification of folate in foods. J Agric Food Chem 1990;38:154-8.

Finglas PM, Faure $U$, Southgate DAT. First BCR-intercomparison un the determination of folates in food. Food Chem 1993;46:199-213.

Finglas PM, Scott KJ, van den Berg H, de Froidmont-Görtz I. EUR-report. The certification of the mass fractions of vitamins in four reference materials: wholemeal flour (CRM 121), milk powder (CRM 421), lyophilised mixed vegetables (CRM 485) \& lyophilised pig's liver (CRM 487). Commission of The European Communities 1999a.

Finglas PM, Wigertz K, Vahteristo L, Witthöft C, Southon S, de Froidmont-Görtz I. Standardisation of HPLC techniques for the determination of naturally-occurring folates in food. Food Chem 1999b;64:245-55.

Gauch R, Leuenberger U, Müller U. Die bestimmung von folsäure (pteroyl-L-glutaminsäure) in lebensmittein mit HPLC. Mitt Gebiete Lebensm Hyg 1993;84:295-302.

Giovannucci E, Stampfer MJ, Colditz GA, Rimm EB, Trichopoulos D, Rosner BA, Speizer FE, Willett WC. Folate, methionine and alcohol intake and risk of colorectum adenoma, J Natl Cancer Inst $1993 ; 85: 875-84$.

Goli DM, Vanderslice JT. Investigation of the conjugase treatment procedure in the microbiological assay of folate. Food Chem 1992;43:57-64.

Gounelle J-C, Ladjimi H. Prognon P. A rapid and specific extraction procedure for folates determination in rat liver and analysis by high-performance liquid chromatography with fluorometric detection. Anal Biochem 1989;176:406-11. 
Gregory JF III, Sartain DB, Day BPF. Fluorometric determination of folacin in biological materials using high performance liquid chromatography. J Nutr 1984;114:341-53.

Gregory JF III, Engelhardt R, Bhandari SD, Sartain DB, Gustafson SK. Adequacy of extraction techniques for determination of folate in foods and other biological materials. J Food Comp and Anal 1990;3:134-44.

Horne DW, Krumdieck CL, Wagner C. Properties of folic acid Y-glutamyl hydrolase (conjugase) in rat bile and plasma. J Nutr 1981;111:442-9.

Iwai K, Tani M, Fushiki T. Electrophoretic and immunological prperties of folate-binding protein isolated from bovine milk. Agric Biol Chem 1983; 47,7:1523-30.

Martin CA. Folate analysis in foods. BNF Nutrition Bulletin 1995;20: 8-15.

Martin JI, Landen Jr WO, Soliman AM, Eitenmiller RR. Application of a tri-enzyme extraction for total folate determination in foods. JAOAC int 1990; 73,5:805-8.

MRC Vitamin Study Research Group. Prevention of neural tube defects: Results of the Medical Research Council Vitamin Study. The Lancet 1991; 338:131-7.

Müller $H$. Bestimmung der folsäure-gehalte von getreide, getreideprodukten, backwaren und hülsenfrüchten mit hilfe der hochleistungsflüssigchromatographie (HPLC). Z Lebensm Unters Forsch 1993;197:573-7.

Pfeiffer CM, Diehl JF, Schwack W. Nahrungsfolate - Eine aktuelle übersicht. Stabilität, physiologische bedeuting, bioverfugbarkeit, analytische bestimmungsmethoden, einfluss der lebensmittelhandlung. Z Ernährungswiss 1994;33:85-119.

Pfeiffer CM, Rogers LM, Gregory JF III. Determination of folate in cereal-grain food products using trienzyme extraction and combined Affinity and reversed-phase liquid chromatography. J Agric Food Chem 1997;45:407-13.

Pocklington WD. Harmonized protocols for the adoption of standardized analytical methods and for the rpesentation of their performance characteristics. Pure Appl Chem 1990; 62:149-62.

Sauberlich HE, Kretsch MJ, Skala JH, Johnson HL, Taylor PC. Folate requirement and metabolism in nonpregnant women. Am J Clin Nutr 1987;46:1016-28.

Selhub J. Determination of tissue folate composition by affinity chromatography followed by highpressure ion pair liquid chromatography Anal Biochem 1989;182: 84-93.

Svendsen I, Martin B, Pedersen TG. Isolation and characterization of the folate-binding protein from cow's milk. Carlsberg Res Commun 1979;44:89-99.

Tamura T, Stokstad ELR. The availability of food folate in man. Brit J Haematol 1973;25:513-32.

Tamura T, Mizuno $Y$, Johnston KE, Jacob RA. Food folate assay with protease, $\alpha$-amylase, and folate conjugase treatments. J Agric Food Chem 1997;45:135-9.

Vahteristo $L T$, Ollilainen $V$, Koivistoinen PE, Varo $P$. Improvements in the analysis of reduced folate monoglutamates and folic acid in food by high-performance liquid chromatography. J Agric Food Chem 1996;44: 477-82.

Vahteristo LT, Ollolainen $\mathrm{V}$, Varo $\mathrm{P}$. Liquid chromatographic determination of folate monoglutamates in fish, meat, egg, and dairy products consumed in Finland. JAOAC Int 1997;80,2: 373-8.

Van den Berg $H$, Steegers-Theunissen RPM. Folate adequacy in The Netherlands. TNO Nutrition and Food Research Institute Zeist, The Netherlands 1997 (report).

Wilson SD, Horne DW. High-performance liquid chromatographic determination of the distribution of naturally occuring folic acid derivates in rat liver. Anal Biochem 1984;142:529-35.

Wilson SD, Horne DW. High-performance liquid chromatographic separation of the naturally occurring folic acid derivates. Methods in Enzymology 1986;122:269-73.

White Jr DR. Determination of 5-methyltetrahydrofolate in citrus juice by reversed-phase highperformance liquid chromatographic detection. J Agric Food Chem 1990;38:1515-8. 


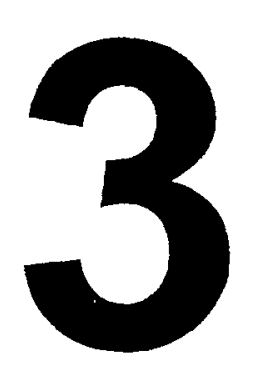

\section{Folate intake of the Dutch population according to newly established liquid chromatography data for foods}

Erik J.M. Konings, Harry H.S. Roomans, Elisabeth Dorant, R. Alexandra Goldbohm, Wim H.M. Saris, Piet A. van den Brandt

The American Journal of Clinical Nutrition 2001;73:765-76 


\section{ABSTRACT}

Background: Determining folate intake is difficult because existing folate data in food-composition tables are scarce and unreliable.

Objective: The purposes of this study were first to analyze 125 of the most important foods that contribute to folate intake in the Netherlands and second to estimate the folate intake of a representative sample of the population.

Design: We analyzed the folate content of foods by using a newly developed HPLC trienzyme method combined with an affinity chromatography cleanup step. These results were then used to estimate the folate intake of persons aged 1-92 who participated in the second Dutch National Food Consumption Survey (DNFCS) in $1992(n=6218)$.

Results: For 35 important folate-containing foods, the mean relative folate contents measured by HPLC were $66 \%, 80 \%$, and $77 \%$ of values for comparable foods included in the British food-composition table, the Ministry of Agriculture, Fisheries and Food table and the US Department of Agriculture database respectively. P-values for comparison of relative values with $100 \%$ were 0.001 , 0.171 , and 0.144 , respectively. The mean dietary folate intake of the DNFCS was $182 \pm 119 \mu \mathrm{g} / \mathrm{d}$. Intake of supplement users $(n=86)$ was $344 \mu \mathrm{g} / \mathrm{d}$, with $147 \mu \mathrm{g} / \mathrm{d}$ originating from supplements. On the basis of these findings $42 \%$ of men and $54 \%$ of women do not meet current Dutch recommendations of $60 \mu \mathrm{g} / \mathrm{d}$ for children and $200 \mu \mathrm{g} / \mathrm{d}$ for adults.

Conclusions: Total folate quantities in foods, analyzed by HPLC are $\approx 25 \%$ lower than amounts listed in recent food composition tables estimated by use of the microbiological method. On the basis of these new data, $\approx 50 \%$ of a representative Dutch population sample does not meet the current recommendations for folate intake.

KEY WORDS: Folate, folate intake, consumption survey, HPLC, foods, trienzyme treatment, food-composition table, Dutch National Food Consumption Survey 


\section{INTRODUCTION}

Folates are part of an extended family of polyglutamates (usually containing 5-7 glutamyl residues) of pteroic acid and related analogues that qualitatively exhibit the biological activity of folic acid. It has become clear that folates play important roles not only in the prevention of neural tube defects (MRC Vitamin Study Research Group 1991, Czeizel et al. 1992), but possibly also in the etiology of cardiovascular diseases (Boushy et al. 1995, Verhoef et al. 1996) and cancer (Giovannucci et al. 1993, Glynn \& Albanes 1994, Giovannucci 1998).

Average folate intakes from foods for adults, as reported in various European countries, range between 168 and $326 \mu \mathrm{g} / \mathrm{d}$ (de Bree et al. 1997). It has been impossible to compare folate intakes between different countries because of the absence of reliable data for folates in food products. Tamura (Tamura 1997, Tamura 1998) suggested that all food folate tables be reevaluated to obtain more reliable values.

The total folate content of foods is usually determined by microbiological assay (Ball 1994, Eitenmiller \& Landen 1999). However, these assays have poor precision and fail to differentiate between several folates. Determination of folate monoglutamates is not possible because the microorganisms also respond to diand triglutamylfolates. The microorganisms might respond unequally to various folate forms; additionally, certain food components could stimulate or inhibit bacterial growth, resulting in unreliable data (Ball 1994).

The average bioavailability of folates from foods has been estimated at about $50 \%$ (Sauberlich et al. 1987). The bioavailability of folate monoglutamates might vary between 70 and $120 \%$ relative to folic acid (100\%) (Tamure \& stokstad 1973). More detailed information about food folate composition is needed to accurately describe intakes and to evaluate the results of bioavailability studies and epidemiological studies related to disease endpoints.

So far, few studies have provided detailed information on the folate composition of foods (Müller 1993a, 1993b, 1993c, Vahteristo et al. 1996, 1997a, 1997b). In addition, the extraction procedure used in these studies was incomplete for certain products because no amylase or protease was used to release folates from cereal or milk products, respectively. Anion exchange chromatography, an unspecific cleanup step that results in many compounds that interfere with chromatography, is a drawback in most of the methods applied. Recently, affinity chromatography was used as an improved purification method by Selhub (Selhub 1989) and was applied to food folates by Seyoum and Selhub (1993). For the HPLC analysis of folates in cereal-grain products, this cleanup step was used successfully by Pfeiffer et al. (1997). The analytic methods used in the present study are based on the work of these investigators. 
The purpose of our study was 2-fold: first, to analyze the folate content of the most important foods contributing to folate intake, and second, to estimate the folate intake of a representative sample of the Dutch population on the basis of these newly assessed folate values. An improved and validated HPLC method (Konings 1999) was used to gather more detailed and valid information about food folate composition.

\section{SUBJECTS AND METHODS}

Foods for folate analysis were selected on the basis of the second Dutch National Food Consumption Survey (DNFCS), which was carried out in 1992 (Löwik et al. 1998). The first survey was executed in 1987 and is described by Hulshof (1991). The DNFCS comprises 6218 noninstitutionalized persons aged 1-92 years in 2475 households selected from a stratified probability sample in the Netherlands. Information on food consumption was obtained with a 2-day dietary record on 2 consecutive days per person, resulting in data for mean consumption of foods in $\mathrm{g} / \mathrm{d}$. The survey was distributed equally over the 7 days of the week and over $1 \mathrm{y}$ (except holidays) from January to December 1992. Data on the use of dietary supplements were obtained by means of a semi-open-ended question asking for types, doses per day and brand names.

\section{Food sample selection.}

First, the folate intake of all foods mentioned in the DNFCS was calculated by using data from international food tables compiled by Brants and Hulshof (1995). Most of these data originated from the British food composition table (Holland et al. 1991). Next, 125 food items were selected for chemical analysis, (Appendix A); these foods contributed $\approx 90 \%$ of total folate intake according to the existing data in the international food tables. The selected food items were mainly vegetables, fruit, bread, milk and milk products, and meat products.

\section{Sample composition}

For all foods selected, information on the most important brands sold and on market shares was obtained from commodity boards and a commercial market research agency. The most frequently consumed fruit and vegetable varieties were collected from the major sales channels (eg, marketplaces, supermarkets, and greengrocers). In the Netherlands there are few distribution centers for fruit and vegetables, so samples were collected at local supermarkets, greengrocers and marketplaces. If folate amounts in foods were suspected to be subject to regional variations, samples were collected from the most important sales channels in 3 regions: Maastricht (south), Gouda (west) and Zwolle (north and east). This was done for milk and milk products and bread. When the season could be a cause of 
variations in folate amounts, for example in vegetables, samples were acquired in various seasons. For 3-5 of the main brands of a food item and for items for which no brand names were used (eg, vegetables, fruit and bread), 3 different production codes or sales locations were sampled in the units in which the products were sold. Selected brands or sales channels covered $>75 \%$ of the supply. All samples were purchased in 1996 and 1997. Because folates might be subject to destruction by exposure to heat, air and light during food preparation, foods were analyzed as consumed, to determine the actual intake of folates.

Samples of some brands with different production codes or from different sales channels were mixed, by brand or sales channel, and prepared immediately according to normal household practice (Henderson \& Toors 1996). Subsequently, different brands or sales channel samples were mixed according to the corresponding market shares, yielding the final sample for analysis. All sampling operations were described in a sampling plan (Konings 1997). Prepared samples $(2-3 \mathrm{~kg})$ were homogenized immediately in liquid nitrogen. About $200 \mathrm{~g}$ was stored at $-80^{\circ} \mathrm{C}$. Analysis usually took place within $1-2$ months of storage.

Several vegetable samples that had been analyzed for carotenoids by Goldbohm et al. (1998) were also used for folate assessment.

\section{Quality control}

Several procedures were carried out to validate the means of homogenization, examine moisture changes, and determine analytical quality control.

To validate the homogenization procedure, $\approx 2.5 \mathrm{~kg}$ spinach was prepared under normal household practice conditions and was immediately frozen and homogenized in liquid nitrogen. The homogenized sample was divided into 10 polypropylene jars. Each jar was filled with approx. $100 \mathrm{~g}$ homogenate and stored at $-80^{\circ} \mathrm{C}$ until analyzed. From every jar, 2 test portions of $\approx 5 \mathrm{~g}$ were taken for folate analysis.

To examine possible moisture changes during the homogenization procedure, 10 samples of vegetables and fruit were homogenized with and without liquid nitrogen. These samples included broccoli, banana, orange, kiwi, red cabbage, potato, spinach, kale, snap beans and chicory.

Analytical quality control was implemented by use of certified reference materials (CRMs) for folates supplied by the Institute for Reference Materials and Measurement in Geel, Belgium. These materials included lyophilized pig liver (CRM 487), milk powder enriched with folic acid (CRM 421), vegetable mix (CRM 485) and whole-meal flour (CRM 121). CRMs were used as controls in each series of sample analysis. 


\section{Analysis}

Detailed information about the method of analysis was published previously (Konings 1999). Briefly, folates from food samples were extracted by homogenization in a Ches-Hepes buffer $(\mathrm{pH} 7.8 ; 2 \%$ ascorbic acid and $10 \mathrm{mmol} 2-$ mercaptoethanol $/ \mathrm{L}$ ) followed by heat treatment, and subjected to heat treatment (10 minutes in a boiling water bath). A first aliquot was analyzed without the addition of any enzymes (treatment 1) to estimate the monoglutamate content of the samples. In a second aliquot, folate concentrations were quantified after the addition of rat plasma conjugase ( $\gamma$-Glu-X carboxypeptidase; treatment 2 ) to establish the sum of monoglutamates and polyglutamates. In a third aliquot, folate concentrations were determined after treatment with rat plasma conjugase plus protease and amylase (treatment 3 ). The difference between the folate amounts assayed in treatments 1 and 2 represents the folate polyglutamate content. The difference between the folate amounts assayed in treatments 2 and 3 reflects matrix-bound folates. After purification by affinity chromatography, folate monoglutamates were measured by using an HPLC method with fluorescence and diode array detection. All analyses were performed under subdued light. This procedure was used to assess the most abundant folate forms naturally present in foods, including tetrahydrofolate $\left(\mathrm{H}_{4}\right.$ folate), 5-methyltetrahydrofolate $\left(5-\mathrm{CH}_{3}\right.$ $\mathrm{H}_{4}$ folate), 5-formyltetrahydrofolate $\left(5-\mathrm{CHO}-\mathrm{H}_{4}\right.$ folate), 10-formylfolic acid (10- $\mathrm{HCO}-$ folic acid), 10-formyldihydrofolate (10- $\mathrm{HCO}-\mathrm{H}_{2}$ folate) and folic acid.

\section{Comparison with other studies and values}

Folate contents (by HPLC) for 35 important folate containing foods such as milk, vegetables, fruit, potatoes and bread were compared with folate amounts reported in 3 other tables: McCance and Widdowson's The Composition of foods (Holland et al. 1991) derived from microbiological analysis carried out before 1990; the folate contents reported in 1996 by the British Ministry of Agriculture, Fisheries and Food (MAFF) (Lawrence 1996), also based on microbiological analyses; and microbiological data from the U.S. Department of Agriculture (USDA) Nutrient Database for Standard Reference (1998). The choice of 35 foods for comparison was based on the availability of folate data in all 3 food-composition tables.

\section{Seasonal variations}

For vegetables, fruit, potatoes, and milk products, samples were taken 2 or 3 different times over a $1-y$ period. For each vegetable, the choice of the sampling time was based on the supply and varieties available. The following vegetables were sampled at various times: endive, beets, leeks, lettuce, spinach, tomatoes, carrots, Brussels sprouts, snap beans, and green beans. Potatoes were purchased immediately after harvesting and at the end of the winter season. Analytical results for the various sampling periods were pooled if values were within the margins of 
reproducibility. Mean relative within-laboratory reproducibility for $5-\mathrm{CH}_{3}-\mathrm{H}_{4}$ folate in the 4 matrices validated (Konings 1999) was 30\%. Within-laboratory reproducibility was defined as $1.6 \times$ repeatability (International Organization for Standardization, Pocklington 1990).

The following fruit varieties were sampled in November and February: orange, grapefruit, tangerine, banana, and kiwi. These months were selected for these products on the basis of information from product boards indicating that consumption levels were highest during the first and last quarters of the year.

The following milk products were sampled in August (cows in meadow) and in March (cows at stable): whole milk, low-fat milk, skim milk, buttermilk, whole yogurt, low-fat yogurt and vanilla custard.

\section{Cooking losses}

The purpose of the present study was to analyze food products in the form in which they are consumed. Thus, some vegetables that can be consumed either raw or cooked were analyzed as such. First, folates were analyzed in cooked products. Second, the folate contents of cooked products were recalculated to the raw state by correcting for weight loss during preparation. These concentrations were then compared with the folate contents of the raw products, allowing us to calculate folate losses. Cooking losses of folates for endive, spinach, onions, red cabbage, carrots and cauliflower were examined.

Endogenous conjugases in vegetables and fruit may cleave folate polyglutamates into monoglutamates during preparation, resulting in lower polyglutamate amounts in the cooked products than in the immediately heated products. Endogenous conjugase is usually deactivated during cooking (Leichter 1980). Raw spinach was chopped before storage at $-80^{\circ} \mathrm{C}$, resulting in higher monoglutamate contents (Appendix A). To investigate the rate of this deconjugation we analyzed chopped spinach for folates after 10,30 and 60 minutes of storage at room temperature.

\section{Calculation of intake}

To establish a more valid estimate of folate intake for the participants of the DNFCS, the folate values assessed with the use of the new HPLC method were used to recalculate folate intake. The random sample of participants in the DNFCS deviated from the Dutch population at large with respect to sex and age distribution. Young children were overrepresented, leading to an underestimation of the consumption of many food products and of the folate intake in the Dutch population. Although the bias is relatively small, we corrected folate intake for sex and age in calculations based on the total database in order to obtain a theoreticaliy more accurate estimation. The corrections were used only for calculating the values for the complete database. Because all persons belonging to 
the same sex-age group have the same correction, calculations in the various groups need not take correction into account (Löwik et al. 1998). Folate contents of those products not included in the above analysis were estimated in several ways. First, analytical values from Appendix A were adopted for comparable foods. For example, the folate content of canned endive was adopted from the analyzed value of fresh, cooked endive. The folate content of low-fat chocolate milk was adopted from the analyzed value of whole chocolate milk because there are small differences in the folate contents of whole and low-fat milks. Second, data from other HPLC methods (Vahteristo et al. 1996, 1997a, 1997b) or the MAFF report (Lawrence 1996) were selected. Finally, folate amounts in the remaining products were calculated from recipes or estimated to be $27 \%$ less then the values listed in the British food composition table (Holland et al. 1991).

Folate intake from supplements was calculated by using information on folic acid content collected from product labels and on the number of tablets used per day. All folic acid supplements and multi-vitamin-mineral preparations were included, except if detailed information on nutrient content was missing. Intakes were calculated for men and women separately and by age groups. To investigate whether persons with high food folate intakes also took supplements, food folate intake was divided into tertiles and the number of supplement users in each tertile was counted.

Folate intakes were compared with the current recommendations in the Netherlands, i.e., $60 \mu \mathrm{g} / \mathrm{d}$ for children to $200 \mu \mathrm{g} / \mathrm{d}$ for aduits; the minimum requirement for adults is assumed to be $100 \mu \mathrm{g}$ folate/ $\mathrm{d}$ and that for pregnant women or women capable of becoming pregnant is $400 \mu \mathrm{g} / \mathrm{d}$ (Voedingsraad 1992, Gezondheidsraad/Noedingsraad 1993). Recently, a new dietary reference intake (DRI) of $400 \mu \mathrm{g}$ DFE (dietary folate equivalent) was reported in the United States (Institute of Medicine, Panel on folate, other B-vitamins, and choline 1998). The DFE unit corrects for a greater bioavailability of synthetic folic acid than of natural folates; $100 \mathrm{mg}$ provided as food folate equals $100 \mathrm{mg}$ DFE, whereas $100 \mathrm{mg}$ provided as folic acid equals $170 \mathrm{mg}$ DFE.

\section{Statistical analysis}

Quality control data and folate intake data are presented as means \pm SDs. The certified value for $5-\mathrm{CH}_{3}-\mathrm{H}_{4}$ folate in mixed vegetables (CRM 485) is presented as the mean $(95 \% \mathrm{Cl})$ of the data set averages. Paired Student's t-tests were performed at the $\mathrm{P}<0.05$ level of significance. To validate the homogenization procedure, folate results for 10 duplicate analyses in spinach were compared by means of a paired Student's t-test. Between-group and within-group variations were examined with analysis of variance. Moisture contents of fruit and vegetables homogenized with 2 procedures were compared by means of a paired Student's ttest. 
The relative values of the HPLC measurements with respect to results in 3 other food-composition tables were compared with $100 \%$ by means of paired Student's ttests on the log-transformed data. For these 3 tests a Bonferroni-corrected $p$-value of 0.017 was used. Log-transformed data were used to improve normal distribution as described by Strike and Dipbiom (1991).

\section{RESULTS}

\section{Selection of foods for HPLC analysis.}

A mean folate intake of $251 \pm 97 \mu \mathrm{g} / \mathrm{d}$ (median: $234 \mu \mathrm{g} / \mathrm{d}$ ) was calculated (Bausch et al. 1995) for a representative sample of the Dutch population with use of the 1992 DNFCS $(n=6218)$ and data from international food tables and compiled by Brants and Hulshof (1995). Intake of folic acid from supplements was not included in these calculations. Food items that provided $>0.1 \%$ of total folate intake were selected for HPLC analysis (Appendix A). Several additional foods were analyzed because of their high folate contents: liver, marmite, wheat germ and wheat bran. $A$ total of 43 vegetables and fruit, 12 types of bread, 14 milk products, 8 meat products and 48 other foods were selected for analysis.

\section{Quality control}

There were no significant differences in $5-\mathrm{CH}_{3}-\mathrm{H}_{4}$ folate concentrations among 20 portions of homogenized spinach ( $P$ : $0.726, \mathrm{CV}: 5.6 \%$ ). Additionally, betweenportion variation was not significantly different from within-portion variation, nor was there any significant difference $(P=0.830)$ in moisture content between vegetable and fruit samples homogenized in liquid nitrogen and ordinary mixed samples.

Mixed vegetables (CRM 485) was used as a control in almost all of the series analyzed. Results for $5-\mathrm{CH}_{3}-\mathrm{H}_{4}$ folate in this material were within the confidence limits of the certified HPLC value. The mean concentration measured was $210 \pm 19$ $\mu \mathrm{g} / 100 \mathrm{~g}(\mathrm{n}=18)$, whereas the certified value for this material was $214 \mu \mathrm{g} / 100 \mathrm{~g}$ (95\% Cl: 172,256). Milk powder (CRM 421) and whole-meal Flour (CRM 121) were each also used once. Folate quantities for these materials were within margins of certified and values.

\section{Analytical results}

The results of the folate analyses in foods are summarized in Appendix A, which shows the amounts of individual folates in each food item as well as the total folate concentration, calculated as folic acid. Folate amounts ranged from 0 to 1827 $\mu \mathrm{g} / 100 \mathrm{~g}$ for apple juice and marmite respectively. Percentages of polyglutamates are also presented for each food item. Vegetables and fruit with the highest folate amounts were broad beans, Brussels sprouts, spinach, strawberries and kiwis, containing respectively $150,87,83,65$ and $23 \mu \mathrm{g}$ folates per $100 \mathrm{~g}$. Other products 
with high folate concentrations included wheat germ $(90 \mu \mathrm{g} / 100 \mathrm{~g})$ and chicken liver (1385 $\mu \mathrm{g} / 100 \mathrm{~g})$.

The vitamer distribution for the most important product categories is illustrated in Figure 1. 5- $\mathrm{CH}_{3}-\mathrm{H}_{4}$ folate was the most abundant vitamer in foods. In the food groups of vegetables and fruit, bread, milk products, potatoes and meat products, $62 \%$ of all vitamers were $5-\mathrm{CH}_{3}-\mathrm{H}_{4}$ folate. Relatively high amounts of $\mathrm{H}_{4}$ folate (the most unstable folate) were found in meat and meat products.

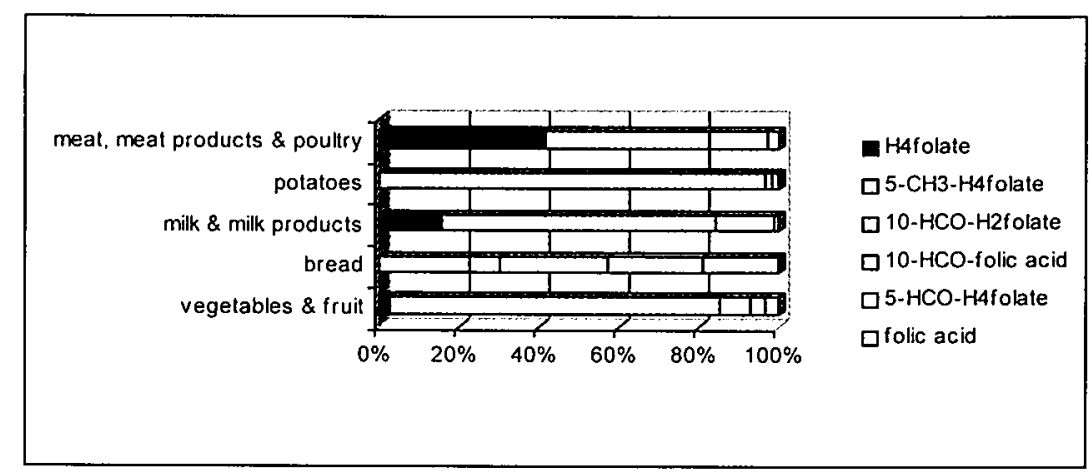

Figure 1. Folate vitamer distribution for important product categories. $\mathrm{H}_{4}$ folate, tetrahydrofolate; 5- $\mathrm{CH}_{3}-\mathrm{H}_{4}$ folate, 5-methyltetrahydrofolate; $10-\mathrm{HCO}-\mathrm{H}_{2}$ folate, 10 -formyldihydrofolate; $10-\mathrm{HCO}$ folic acid, 10-formylfolic acid; 5-HCO-H $\mathrm{H}_{4}$ folate, 5-formyltetrahydrofolate.

Polyglutamate and matrix-bound folate contents measured after treatments 1,2 and 3 are listed in Table 1. Samples treated with amylase and protease during extraction yielded higher folate concentrations in fruit (16\%) and milk products $(21 \%)$, than did samples not treated with these enzymes. Of the total folates in food, $71 \%$ were polyglutamates. 
Table 1. Polyglutamate and matrix-bound folate contents of various foods and food groups ${ }^{1}$.

\begin{tabular}{lcccc}
\hline & $n$ & Sum of folates & $\begin{array}{c}\text { Polygluta- } \\
\text { mates }^{2} \\
\%\end{array}$ & $\begin{array}{c}\text { Matrix-bound } \\
\text { Folates }^{3} \\
\%\end{array}$ \\
\hline Potatoes & 3 & $12 \pm 3$ & $90 \pm 2$ & 0 \\
Vegetables & 24 & $31 \pm 33$ & $80 \pm 21$ & 0 \\
Fruit & 6 & $27 \pm 21$ & $70 \pm 13$ & $16 \pm 13$ \\
Bread & 12 & $26 \pm 7$ & $66 \pm 27$ & 4 \\
Milk and milk products & 14 & $5 \pm 3$ & $64 \pm 21$ & $21 \pm 18$ \\
Meat, meat products \& & 8 & $522 \pm 529$ & $57 \pm 34$ & 0 \\
poultry & & & & \\
\hline
\end{tabular}

\footnotetext{
${ }^{1}$ Mean \pm SD.

${ }^{2}$ Difference between folate amounts assayed after treatment 1 (without the addition of any ezymes) and treatment 2 (after the addition of rat plasma conjugase).

${ }^{3}$ Difference between folate amounts assayed after treatment 2 (after the addition of rat plasma conjugase) and treatment 3 (after the addition of rat plasma conjugase plus protease and amylase).

${ }^{4}$ not determined
}

\section{Comparison with other studies and values}

Results of comparisons of HPLC-determined folate contents with values listed in 3 other food-composition tables are presented in table 2 and figure 2. Concentrations determined by HPLC ranged from 3 to $81 \mu \mathrm{g} / 100 \mathrm{~g}$. The mean relative value of the HPLC results was $66 \%$ of the values given for comparable foods in McCance and Widdowson's table and was significantly different from $100 \%\langle P=0.001$ after Bonforroni correction).

Table 2. Comparison of total folate content of 35 food items assessed by LC and values from other food composition tables.

\begin{tabular}{lccc}
\hline & $\begin{array}{c}\text { McCance \& Widdow- } \\
\text { son's }\end{array}$ & MAFF $^{2}$ & USDA $^{3}$ \\
\hline $\begin{array}{l}\text { mean relative LC value } \\
\text { with respect to other } \\
\text { tables }(\%)\end{array}$ & $66^{\circ}$ & 80 & 77 \\
$95 \% \mathrm{Cl}(\%)$ & $54-82$ & $64-101$ & $59-100$ \\
\hline
\end{tabular}

\footnotetext{
${ }^{*} \mathrm{P}<0.05$ vs. LC (after Bonferroni correction)

${ }^{1}$ British Food Composition table (Holland et al. 1991)

${ }^{2}$ Report of English Ministry of Agriculture Fisheries and Food (Lawrence 1996)

${ }^{3}$ USDA Nutrient Database for Standard Reference (USDA 1998)
} 
The mean relative values of the HPLC results with respect to concentrations for comparable foods included in the MAFF table and the USDA nutrient database were $80 \%$ and $77 \%$ respectively and were not significantly different from $100 \%$ $(P=0.171$ and $P=0.144$ respectively).

\section{Seasonal variations}

Analytical results for various vegetables sampled in different seasons were within margins of laboratory reproducibility values. There were no significant differences $(P=0.434)$ in folate intake from these vegetables on the basis of the arithmetic means of results for every season or the means corrected for the number of months by growing season and the percentage of users in several seasons according to the consumption survey (DNFCS).

Folate contents of fruit were not significantly different between samples taken in November and those taken in February $(P=0.102)$. Folate concentrations in milk products were also not significantly different when sampled in August or March $(P=0.111)$. 


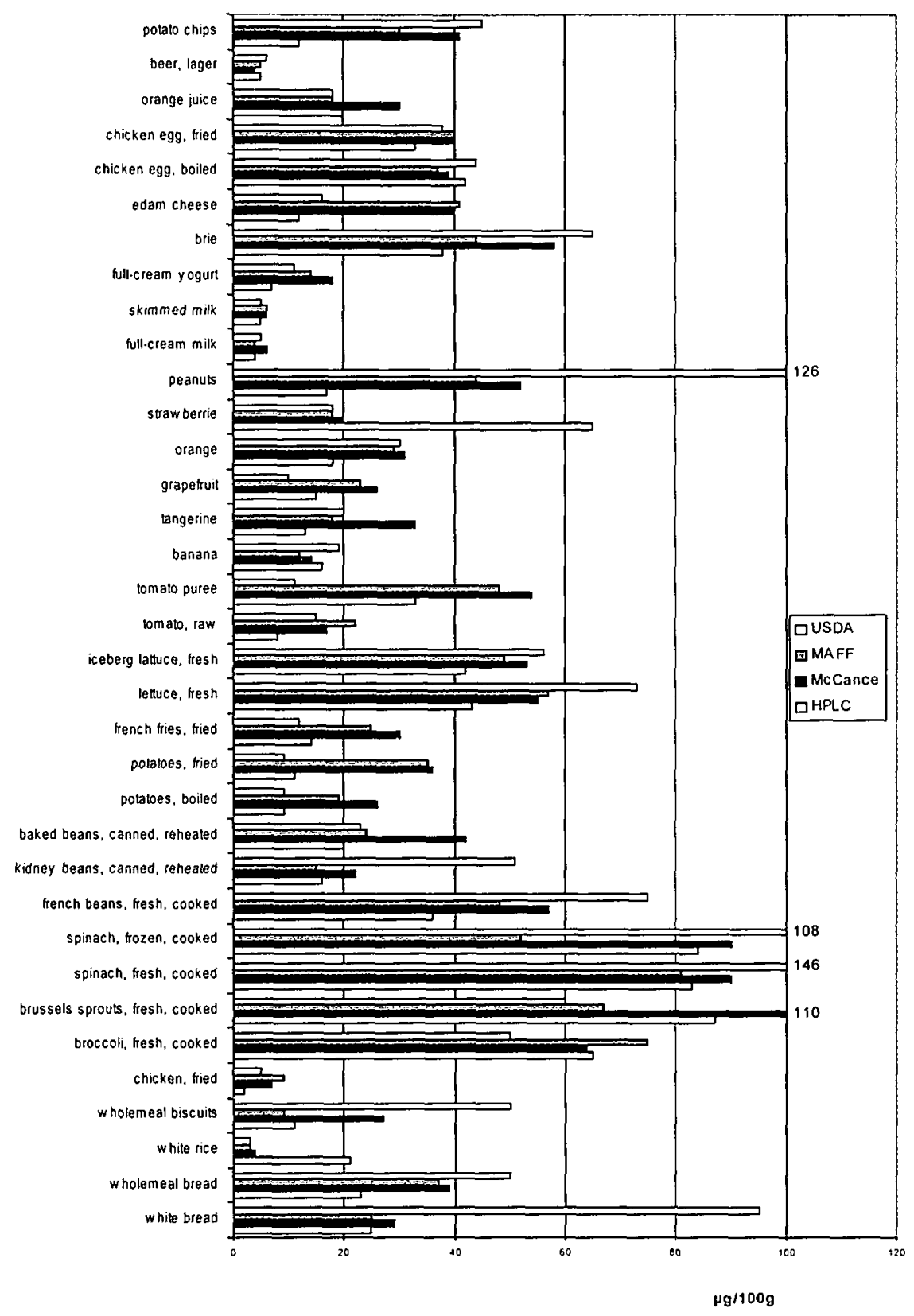

Figure 2. The folate contents of 35 foods on the basis of HPLC analysis compared with contents reported in 3 other databases: USDA, US Department of Agriculture Nutrient Database for Standard Reference; MAFF, British Ministry of Agriculture, Fisheries and Food table; McCance and Widdowson's The Composition of Foods. 


\section{Cooking losses}

Cooking losses of folates from endive, spinach, onion and red cabbage were $56 \%$, $52 \%, 40 \%$ and $29 \%$ respectively. In cooked carrots and cauliflower, folate contents increased by 15 and $11 \%$, respectively.

The percentage of monoglutamates in chopped spinach increased from 25 to 37 to 54 after 10,30 and 60 minutes storage at room temperature, respectively.

\section{Folate intake}

We calculated a mean folate intake of $182 \pm 119 \mu \mathrm{g} / \mathrm{d}$ (median: $164 \mu \mathrm{g} / \mathrm{d}$ ) for a representative sample (aged 1-92y) of the Netherlands population with the use of the 1992 DNFCS $(n=6218)$ and the newly established HPLC values for folates in foods. Foods sampled and analyzed in the procedures described provided $73 \%$ of the total folate intake. Vegetables, fruit, and potatoes provide $>33 \%$ of the daily dietary folate intake $(22 \%, 6 \%$, and $7 \%$, respectively). Bread, milk products and meat products supplied about another $33 \%$ of the daily dietary folate intake $(19 \%$, $9 \%$, and $11 \%$, respectively). Other food products provided $26 \%$ of daily folate intake. Shown in Figure 3 are the relative contributions to total daily dietary folate intake of 35 of the most important sources of folate among participants in the DNFCS. Wheat bread made the greatest contribution $(12.3 \mu \mathrm{g} / \mathrm{d})$ to folate intake in the Netherlands, followed by whole-meal bread $(8.3 \mu \mathrm{g} / \mathrm{d})$ and potatoes $(7.9 \mu \mathrm{g} / \mathrm{d})$. In Figure 4 , folate intake is subdivided by sex and age categories. In the whole DNFCS population, total folate intake in men was significantly higher $(P<0.05)$ than that in women. For the age categories $1-4,4-7,10-13,16-19$, and $>65$ year, total folate intake among men and women was not significantly different $(P>0.05)$. Shown in Table 3 are the mean daily folate intakes of non-supplement-users and supplement users participated in the DNFCS. Total folate intake was also calculated according to the new DRI standards (Institute of Medicine, Panel on folate, other B-vitamins, and choline 1998). The mean daily dietary folate intake for participants aged $\geq 16 y$ was $193 \pm 112 \mu \mathrm{g} / \mathrm{d}$ ( $n=4777,95^{\text {th }}$ percentile: $319 \mu \mathrm{g} / \mathrm{d}$; men: $215 \pm 120 \mu \mathrm{g} / \mathrm{d}$; women: $173 \pm 100 \mu \mathrm{g} / \mathrm{d}$ ).

According to our calculations, $42 \%$ of men and $54 \%$ of women in the DNFCS did not meet the current Dutch folate recommendations of $60 \mu \mathrm{g} / \mathrm{d}$ for children and $200 \mathrm{mg} / \mathrm{d}$ for adults. In the DNFCS, $3.6 \%$ of adult men and $10.6 \%$ of adult women consumed less than the minimum requirement of $100 \mu \mathrm{g} / \mathrm{d}$. According to the new DRI standards, $97 \%$ of the participants in the DNFCS did not meet folate requirements. 


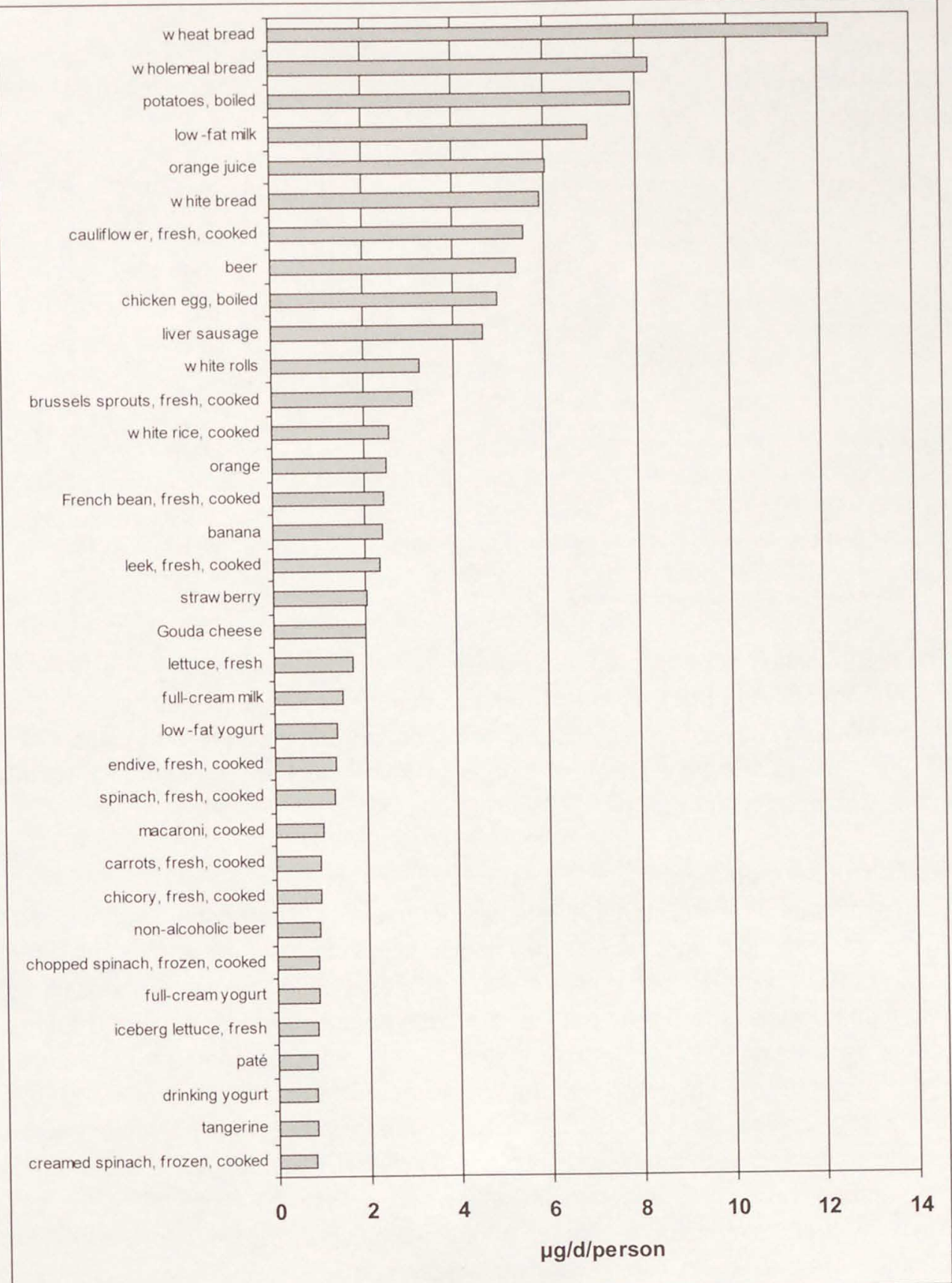

Figure 3. The 35 most important food items contributing to folate intake in the Dutch population aged 1 92 y according to the 1992 Dutch National Food Consumption Survey ( $n=6218$ ). These products provide $\approx 60 \%$ of total folate intake. 


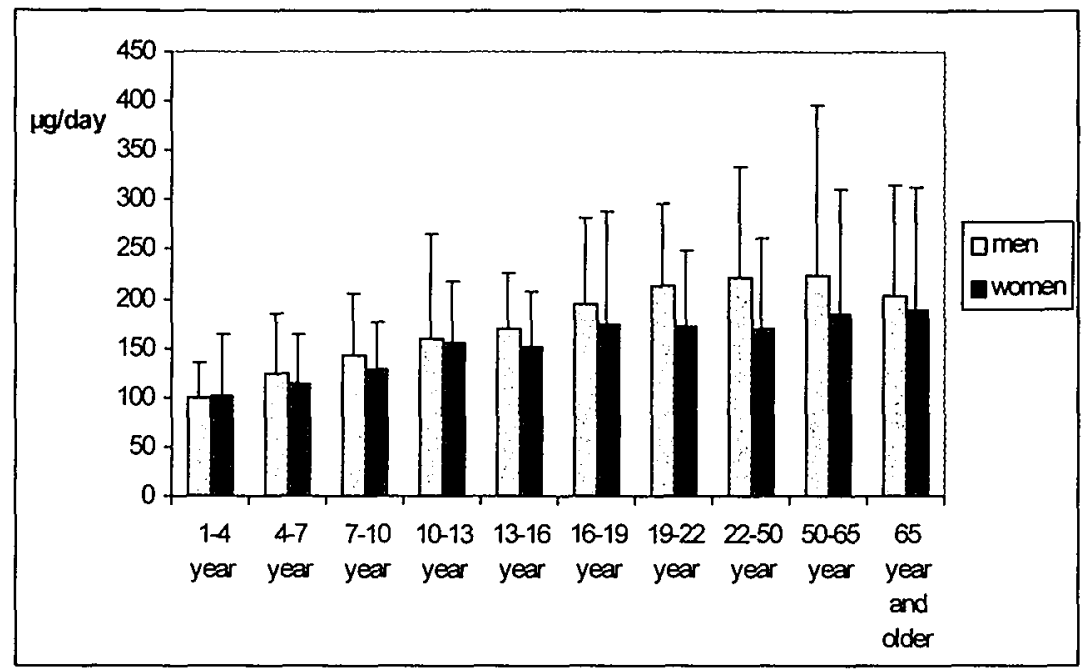

Figure 4. Mean (+SD) folate intakes of the Dutch population aged 1-92 y by age and sex in the 1992 Dutch National Food Consumption Survey $(n=6218)$. Intakes of folic acid as supplements are included.

The mean folate intake for pregnant women ( $n=58$; mean age; $30 y)$ was $187 \pm 62$ $\mu \mathrm{g} / \mathrm{d}$ (range: $54-315 \mu \mathrm{g} / \mathrm{d}$ ). None of these women used folic acid supplements. The mean folate intake for women capable of becoming pregnant (16-50 y) was $172 \pm$ $91 \mu \mathrm{g} / \mathrm{d}(18-1322 \mu \mathrm{g} / \mathrm{d})$. The contribution of folic acid from supplements to this intake was marginal $(2 \mu \mathrm{g} / \mathrm{d})$.

\section{Intake from supplements}

The total folate intake of the 108 supplement users $(1.7 \%$ of population) was 324 $\mu \mathrm{g} / \mathrm{d}$, of which $147 \mu \mathrm{g} / \mathrm{d}$ was from vitamin supplements (range: $7.5-800 \mu \mathrm{g} / \mathrm{d}$; median: $100 \mu \mathrm{g} / \mathrm{d}$; $95^{\text {th }}$ percentile: $400 \mu \mathrm{g} / \mathrm{d}$ ). For $19 \%$ of the supplement users, folate intake was still below the current recommendation of $200 \mu \mathrm{g} / \mathrm{d}$. Of the supplement users, $23 \%$ had intakes higher $>400 \mu \mathrm{g} / \mathrm{d}$. One person had an intake $>1000 \mu \mathrm{g} / \mathrm{d}$. Fifty-eight percent of supplement consumers were women and $80 \%$ of the users were aged $\geq 16 \mathrm{y}$. The mean folate intake for supplement users calculated according to the new DRI standards was $427 \pm 232 \mu \mathrm{g}$ DFE/d. For these supplement users, $60 \%$ had folate intakes below the DRI of $400 \mu \mathrm{g}$ DFE/d.

When total folate intake without supplements was divided into tertiles, the numbers of supplement users were equally spread across the low, medium and high categories of food folate intake $(37,36$ and 35 respectively). 


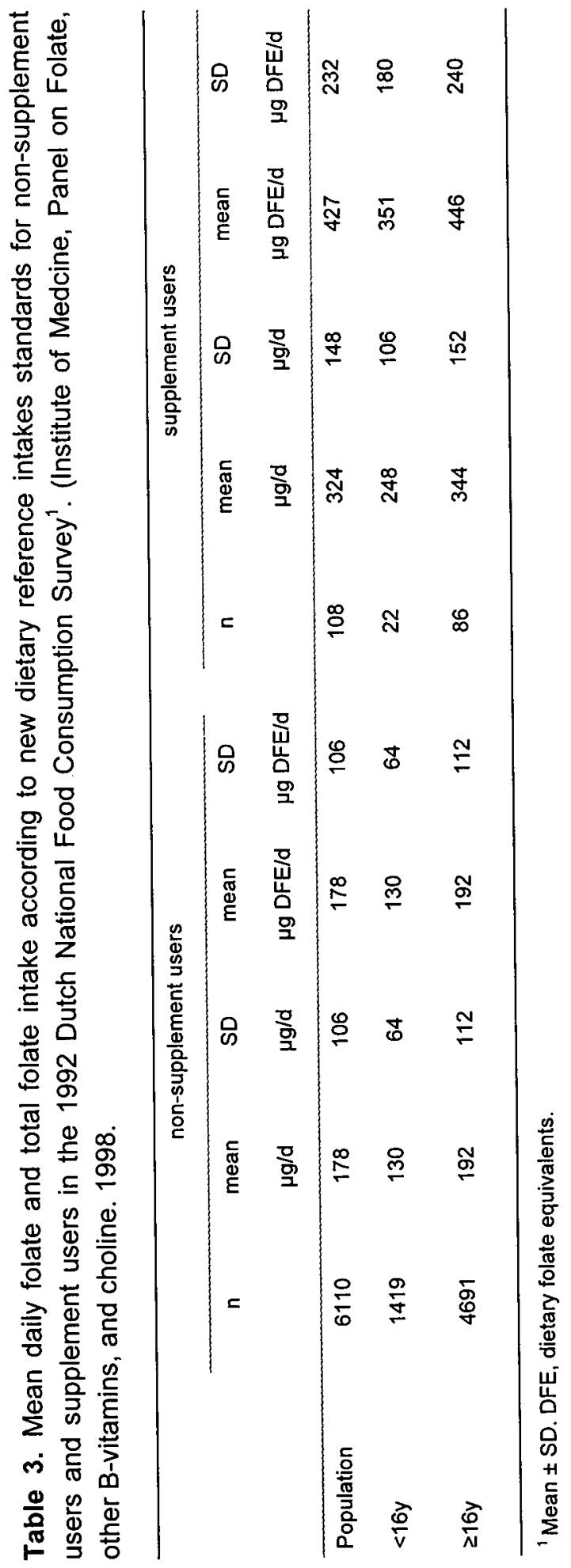




\section{DISCUSSION}

\section{Analytical findings}

The present study provides information on the folate composition of a large set of foods eaten regularly in the Netherlands. All aspects of the study complied with the quality-control criteria for the assessment of food folate composition data emphasized by Holden et al. (1997). In the present study, the sample selection and sampling plan for folate analyses were also based on the considerations put forward by Greenfield and Southgate (1992). The purpose of our study was to determine the actual intake of folates after food preparation.

Our results showed that the method of homogenizing the samples in liquid nitrogen yielded a homogeneous composite with no significant change in moisture content. Analyses of CRMs showed good repeatability between analytical runs. For the vegetable extracts, potatoes and meats, no statistically significant increases in folate amounts were observed after the addition of protease and amylase. For these products, the average analytical results were calculated for the treated and untreated extracts. In contrast, folate concentrations increased by $16 \%$ and $21 \%$ in the fruit and milk products, respectively, after the addition of protease and amylase. The amount of extra release in bread and pasta was not determined because untreated extracts could not be applied to the affinity chromatography columns. The use of amylase/protease resulted in higher folate contents and agrees with recommendations made in other papers (Tamura 1998, Pfeiffer et al. 1997, DeSouza \& Eitenmiller 1990, Martin et al. 1990).

If microbiological methods had been used, $\mathrm{H}_{4}$ folate might have decomposed during the long incubation times. This could be why folate amounts in liver and liver products in current food tables tend to be low. Recently, Vahteristo et al. (1996) reported HPLC-measured folate concentrations in liver comparable with those presented in Appendix A: $730-1470 \mu \mathrm{g} / 100 \mathrm{~g}$ in pig and beef livers (not cooked) and substantial amounts $(480-1050 \mu \mathrm{g} / 100 \mathrm{~g})$ of tetrahydrofolic acid.

Another remarkable finding was the presence of $10-\mathrm{HCO}-\mathrm{H}_{2}$ folate in some vegetables. In some leafy green vegetables (spinach, endive), the ratio between 10- $\mathrm{HCO}-\mathrm{H}_{2}$ folate and $5-\mathrm{CH}_{3}-\mathrm{H}_{4}$ folate was 1:1. 10- $\mathrm{HCO}-\mathrm{H}_{2}$ folate, like 10-HCO-folic acid, is an oxidation product of $10-\mathrm{HCO}-\mathrm{H}_{4}$ folate. These vitamers may have been produced during the preparation or processing of these vegetables. It is unlikely that conversions took place during analysis, in view of the good recoveries of the different folate derivatives. Pfeiffer et al. (1997) were the first to report the presence of $10-\mathrm{HCO}-\mathrm{H}_{2}$ folate in bread. This vitamer was also found in the present study and was probably introduced by yeast because no $10-\mathrm{HCO}-\mathrm{H}_{2}$ folate is found in wholemeal flour (Konings 1999). Pfeiffer et al. (1997) measured folates in unfortified white bread, wheat bread and white rice by HPLC and affinity chromatography (white bread: $21 \mu \mathrm{g} / 100 \mathrm{~g}$; wheat bread: $30 \mu \mathrm{g} / 100 \mathrm{~g}$; white rice $14 \mu \mathrm{g} / 100 \mathrm{~g}$ ) and 
their findings correspond well with ours $(25,27,21 \mu \mathrm{g} / 100 \mathrm{~g}$ respectively). Folate amounts in white rolls were higher than in white bread, probably because twice as much yeast is used in the former.

Seyoum and Selhub (1993) described good agreement between the results of HPLC with affinity chromatography and microbiological methods, but analyzed only 10 food products. Less than 4 products were comparable with the foods analyzed in the present study and the folate contents of these items are not listed in their paper so cannot be compared with our results. Several of the HPLC measurements made in the present study agree well with microbiological results listed in one or more of the food tables used for comparison. However, in general most HPLC measured folate contents were lower than values found by microbiological assay. Because the most abundant folate vitamers present in food products were determined by HPLC, this finding suggests that nonfolate compounds influence the bacterial growth response resulting in higher folate contents with the microbiological assay (Ball 1994). The mean of 35 relative folate values in McCance and Widdowson's food composition table (Holland et al. 1991) was $121 \%$ of values in the MAFF table (Lawrence 1996) and was significantly different from $100 \%(P<0.001)$. Both values were obtained with the use of the microbiological assay (Bell 1974) for the same British food products. This indicates a large variation in microbiological results which could explain part of the difference between our HPLC results and the microbiologically-derived values given in current food tables.

Our HPLC results are $\approx 27 \%$ lower than folate amounts listed in the British food tables and $23 \%$ (NS) lower than the folate amounts described in the USDA nutrient database. This contradicts statements that the folate content in current food tables is underestimated (Tamura 1998).

Seasonal variations in the folate contents of different varieties of vegetables, fruit, potatoes and milk products were small as also reported by Vahteristo et al. (1997b) and Mullin et al. (1982) for some vegetable varieties.

Cooking may have released additional folates in carrots and cauliflower, but these differences can probably be explained by a reproducibility value of $30 \%$ (Konings 1999). DeSouza and Eitenmiller (1986) reported comparable folate losses for blanched spinach.

\section{Folate intake}

With use of our HPLC data, we calculated the dietary folate intake of a representative sample of the Dutch population to be $182 \mu \mathrm{g} / \mathrm{d}$; in contrast, with use of data provided mainly by the British food table, we calculated the intake of this population to be $251 \mu \mathrm{g} / \mathrm{d}$. Compared with data for other European countries [291 $\mu \mathrm{g} / \mathrm{d}$ for adult men and $247 \mu \mathrm{g} / \mathrm{d}$ for adult women (de Bree et al. 1997)] and the United States [242 $\mu \mathrm{g} / \mathrm{d}$, for adults (Subar 1989) and $283 \mu \mathrm{g} / \mathrm{d}$ for persons aged > 
6y (Institute of Medicine, Panel on Folate, other B-vitamins, and choline 1998)], the calculated dietary intake of the Dutch population according to our HPLC data is low. But, as evaluated previously, earlier analytical methods appear to be overestimate folate intake, resulting in $\approx 25 \%$ higher folate values.

According to our calculations, which were based on a 2-d dietary record included in a food consumption survey, about one-half of the DNFCS population failed to meet the Dutch folate requirements. Almost no one had a folate intake meeting to the new DRI standards. Until recently, foods in the Netherlands were not allowed to be fortified with folic acid. An intake of $200 \mathrm{~g}$ vegetables and 2 pieces of fruit daily is currently recommended to enhance the intake of folate and other nutrients. This is approximately double the amount of vegetables and fruit found to be consumed in the 1992 DNFCS. Even if average intakes of vegetables and fruit were doubled (by adding a mean folate intake from vegetables and fruit of $50 \mu \mathrm{g} / \mathrm{d}$ per person), $33 \%$ of adults would still not meet the required $200 \mu \mathrm{g} / \mathrm{d}$. Since regulations requiring the fortification of certain cereal-grain products with synthetic folic acid became effective in the United States in early 1998, new estimated folate intakes for the US population compare favorably with the new DRI standards (Lewis et al. 1999). However, these estimations are not based on actual measurements.

An intake level of $100 \mu \mathrm{g}$ folate/d is deemed to be sufficient to maintain adequate serum folate concentrations in $\geq 80 \%$ of the population (Voedingsraad 1992). Brussaard et al. (1997) found that among 444 Dutch adults, $\approx 10 \%$ of the men and $10 \%$ of the women had low serum folate concentrations on the basis of a cut-off of $7 \mathrm{nmol} / \mathrm{L}$. According to Herbert (1989), this concentration indicates early negative folate balance. Our calculations show more or less comparable percentages of men and women with intakes below the minimum requirement of $100 \mu \mathrm{g} / \mathrm{d}$. Thus, the folate intake calculations in the DNFCS appear to be confirmed by the serum folate concentrations found in Brussaard et al's study.

A folic acid intake of $400 \mu \mathrm{g} / \mathrm{d}$ is advised to prevent neural tube defects. A dietary folate intake of $350 \mu \mathrm{g} / \mathrm{d}$ is recommended to maintain low homocysteine concentrations in plasma, which might prevent cardiovascular diseases (Bree de et al. 1997). According to our calculations, almost the entire DNFCS population failed to meet these folate intakes.

Of the 15 major contributors to folate intake according to the DNFCS, 6 are also among the 15 most important contributors in the U.S. second National Health and Nutrition Examination Survey (1988-1994) (Subar 1989). These include wholemeal bread, low-fat milk, white bread, orange juice, beer, and eggs. The other 9 items differed, reflecting differences in dietary patterns. Many foods with high folate contents, such as broad beans, spinach and broccoli (Appendix A) do not rank high in actual dietary folate intake because of their low consumption rate. Increased consumption of these products could be recommended to enhance folate intake.

Among supplement users, the mean folic acid intake from supplements was $\approx 50 \%$ 
of total folate intake. The effect of supplement use on total folate intake for the whole DNFCS population was small, however, because only $1.7 \%$ of the study population took supplements. In the United States, $28 \%$ of the participants in the second National Health and Nutrition Examination Survey reported the use of supplements containing folic acid. In that survey, supplemental folic acid contributed $68 \%$ of total folate intake (Institute of Medicine, Panel on Folate, other B-vitamins, and choline 1998).

Because the number of supplement users in the present study was distributed evenly in the low, medium, and high food folate intake groups, we found no indication that only persons with high food folate intakes also took supplements.

In summary, this study provides information on food folate composition with use of a newly developed HPLC method. Folate intake values calculated for a representative sample of the Dutch population with the use of these data show a relatively low folate intake compared to the new DRI standards.

\section{ACKNOWLEDGEMENTS}

We thank C.H.I. Florisson of the Inspectorate for Health Protection and Veterinary Public Health in 's Hertogenbosch for her practical assistance; K.F.A.M. Hulshof and H.A.M. Brants of the TNO Nutrition and Food Research Institute, The Netherlands, for their assistance in designing the food sampling plan and database; and A.D.M. Kester of Maastricht University, Department of Methodology and Statistics for assistance.

\section{REFERENCES}

Bausch-Goldbohm RA, Hulshof KFAM, Brants HAM, van den Berg $H$, Bouman M. De inneming van foliumzuur door verschillende bevolkingsgroepen in Nederland voor en na verrijking van bepaalde voedingsmiddelen. (Folate intake of the Dutch population before and after enrichment of certain foods.) Zeist, Netherlands: TNO Nutrition and Food Research Institute, 1995 (in Dutch). (Report V 95.184.)

Ball GFM. Microbiological methods for the determination of the B-group vitamins. In: Water-soluble vitamin assays in human nutrition. London: Chapman \& Hall, 1994: 317-464.

Ball GFM. Appraisal of analytical techniques. In: Water-soluble vitamin assays in human nutrition. London: Chapman \& Hall. 1994: 387-400.

Bell JG. Microbiological assay of vitamins of the B group in foodstuffs. Lab Pract 1974;23:235-42.

Boushy CJ, Beresford SAA, Omenn GS, Motulsky AG. A quantitative assessment of plasma homocysteine as a risk factor for vascular disease. JAMA 1995;274,13:1049-57.

Brants HAM, Hulshof KFAM. De ontwikkeling van een voedingsmiddelentabel met foliumzuurgehaltes (The development of a food composition table for folate data). Zeist, Netherlands: TNO Nutrition and Food Research Institute, 1995 (in Dutch). (Report V 95.089)

Brussaard JH, Löwik MRH, van den Berg H, Brants HAM, Goldbohm RA. Folate intake and status among adults in the Netherlands. Eur J Clin Nutr 1997;51:S46-50.

Czeizel AE, Dudás I. Prevention of the first occurrence of neural tube defects by periconceptional vitamin supplementation. N Engl J Med 1992;327:1832-5. 
de Bree $A$, van Dusseldorp $M$, Brouwer IA, van het $H$ of $K H$, Steegers-Theunissen RPM. Folate intake in Europe: recommended, actual and desired intake. Eur J Clin Nutr 1997;51:643-60.

DeSouza SC, Eitenmiller RR. Effects of different enzyme treatments on extraction of total folate from various foods prior to microbiological and radioassay. J Micronutr Anal 1990;7:37-57.

DeSouza SC, Eitenmiller RR. Effects of processing and storage on the folate content of spinach and broccoli. J Food Sci 1986;51:626-8.

Eitemiller RR, Landen WO Jr. Folate. In: Vitamin analysis for the health and food sciences. London: CRC Press, 1999: 411-66.

Gezondheidsraad/Noedingsraad. Vervolgadvies inzake foliumzuurvoorziening in relatie tot neuraalbuisdefecten. (Advice concerning folic acid intake in respect of neural tube defects.) The Hague: Voorlichtingsbureau voor de Voeding, 1993 (in Dutch).

Giovannucci E, Stampfer MJ, Colditz GA et al. Folate, methionine and alcohol intake and risk of colorectal cancer. J Natl Cancer Inst 1993;85:875-84.

Giovannucci E, Stampfer MJ, Graham AC. Multivitamin use, folate, and colon cancer in women in the Nurses' Health Study. Ann Intern Med. 1998;129:517-24.

Glynn SA, Albanes D. Folate and cancer: a review of the literature. Nutr Cancer 1994;22:101-19.

Goldbohm RA, Brants HAM, Hulshof KFAM, van den Brandt PA. The contribution of various foods to intake of vitamin $A$ and carotenoids in the Netherlands. Int J Vitam Nutr Res 1998;68:378-83.

Greenfield $\mathrm{H}$, Southgate DAT. Food composition data. Production, management and use. New York: Elsevier Applied Science, 1992.

Henderson $\mathrm{H}$, Toors $\mathrm{H}$. Het nieuwe kookboek. (The new Dutch Cookbook.) Utrecht, Netherlands: Kosmos, 1996 (in Dutch).

Herbert $V$. Making sense of laboratory tests of folate status: folate requirements to sustain normally. In: Zittoun J, Cooper BA, eds. Folates and cobalamines. Berlin: Springer-Verlag, 1989:119-27.

Holden J, Beecher G, Doherty R, Davis $C$, Finglas P. Evaluation system for the assessment of folate composition data of foods. Proceeding paper from 16th International Congress of Nutrition, Montreal Canada, 1997.

Holland B, Welch AA, Undin JD, Buss DH, Paul AA, Southgate DAT. McCance and Widdowson's the composition of foods. Fifth revised and extended edition. Cambridge, United Kingdom:The Royal Society of Chemistry and Ministry of Agriculture, Fisheries and Food, 1991.

Hulshof KFAM. The Dutch National Food Consumption Survey: design, methods and first results. Food Policy 1991; June:257-60.

International Organization for Standardization. ISO 5725. Accuracy of measurements, methods and results. Geneva: International Organization for Standardization. 1987.

Institute of Medicine, Panel on Folate, Other B-Vitamins, and Choline. Dietary reference intakes: thiamin, riboflavin, niacin, vitamin $B_{6}$, folate, vitamin $B_{12}$, pantothenic acid, biotin, and choline. Washington, DC: National Academy Press, 1998.

Konings EJM. Monsternameprotocol voor foliumzuuranalyse. (Sampling plan for folate analyses.) 'sHertogenbosch, Netherlands: Inspectorate for Health Protection and Veterinary Public Health, 1997 (in Dutch) (Report MA 9701.)

Konings EJM. A validated LC method for the determination of folates in vegetables, milk powder, liver and flour. J AOAC Int 1999;82,1:119-27.

Lawrence P. Individual folates in foodstuffs. MAFF project 2B033, July 1996. London: MAFF, 1996. (Report number AS20/96/88.)

Leichter J. Folate content in the solid and liquid portions of canned vegetables. Can Inst Food Sci Technol 1980;13,1:33-4.

Lewis CJ, Crane NT, Wilson DB, Yetley EA. Estimated folate intakes: data updated to reflect food fortification, increased bioavailability, and dietary supplement use. Am J Clin Nutr 1999;70:198207.

Löwik MRH, Hulshof KFAM, van der Heijden LJM et al. Changes in the diet in the Netherlands: 1987-88 to 1992. Int J Food Sci Nutr 1998;49 (suppl 1):S1-64. 
Martin J, Landen WO Jr, Soliman AM, Eitenmiller RR. Application of a tri-enzyme extraction for total folate determination in foods. J AOAC Int 1990;73:805-8.

MRC Vitamin Study Research Group. Prevention of neural tube defects: results of the Medical Research Council Vitamin Study. Lancet, 1991;338:131-7.

Mullin WJ, Wood DF, Howsam SG. Some factors affecting folacin content of spinach, Swiss chard, broccoli and Brussels sprouts. Nutr Rep Int 1982;26:7-16.

Müller $H$. Determination of folic acid contents in vegetables and fruit by means of HPLC. $Z$ Lebensm Unters Forsch 1993;196:137-41.

Müller $\mathrm{H}$. Determination of folic acid content in foods of animal origin by means of HPLC. $\mathrm{Z}$ Lebensm Unters Forsch 1993;196:518-21.

Müller $\mathrm{H}$. Determination of the folic acid content of grain, cereal products, bakery products and legumes by means of HPLC. Z Lebensm Unters Forsch 1993;197:573-7.

Pfeiffer CM, Rogers LM, Gregory JF III. Determination of folate in cereal-grain food products using trienzyme extraction and combined affinity and reversed-phase liquid chromatography. J Agric Food Chem 1997;45:407-13.

Pocklington WD. Harmonized protocols for the adoption of standardized analytical methods and for the presentation of their performance characteristics. Pure Appl Chem 1990;62,1:149-62.

Sauberlich HE, Kretsch MJ, Skala JH, Johnson HL, Taylor PC. Folate requirement and metabolism in nonpregnant women. Am J Clin Nutr 1987;46:1016-28.

Selhub J. Determination of tissue folate composition by affinity chromatography followed by highpressure ion pair liquid chromatography. Anal Biochem 1989;182:84-93.

Seyoum E, Selhub J. Combined affinity and ion pair column chromatographie for the analysis of food folate. J Nutr Biochem 1993;4:488-94.

Strike PW, Dipbiom PG. Statistical methods in laboratory medicine. Oxford, United Kingdom: Butterworth-Heinemann Ltd, 1991:117-9.

Subar AF, Block G, James LD. Folate intake and food sources in the US population. Am $\mathrm{J}$ Clin Nutr 1989;50:508-16.

Tamura T, Stokstad ELR. The availability of food folate in man. Br J Haematol 1973;25:513-32.

Tamura T. Bioavailability of folic acid in fortified food. Am J Clin Nutr 1997;66:1299-300.

Tamura T. Determination of food folate. Nutr Biochem 1998;9:285-93.

US Department of Agriculture, Agricultural Research Service. USDA nutrient database for standard reference, release 12. 1998. World Wide Web: http://www.nal.usda.gov/fnic/foodcomp (accessed 15 January 2001).

Vahteristo LT, Ollilainen V, Varo P. HPLC determination of folate in liver and liver products. J Food Sci 1996;61:524-6.

Vahteristo LT, Ollilainen V. Varo $P$. Liquid chromatographic determination of folate monoglutamates in fish, meat, egg and dairy products consumed in Finland. J AOAC Int 1997;80,2:373-8.

Vahteristo LT, Lehikoinen $K$, Ollilainen V, Varo P. Application of an HPLC assay for the determination of folate derivates in some vegetables, fruit and berries consumed in Finland. Food Chem 1997;59:589-97.

Verhoef $P$, Stampfer MJ, Buring JE et al. Homocysteine metabolism and risk of myocardial infarction: relationship with vitamins $B_{6}$, vitamin $B_{12}$ and folate. Am J Epidemiol 1996;134:845-59.

Voedingsraad. Nederlandse Voedingsnormen 1989. Advies opgesteld door de Commissie Voedingsnormen, Den Haag 13 juli 1989. $2^{e}$ druk. (Dutch recommendations for intake of nutrients.) The Hague: Voorlichtingsbureau voor de Voeding, 1992 (in Dutch). 


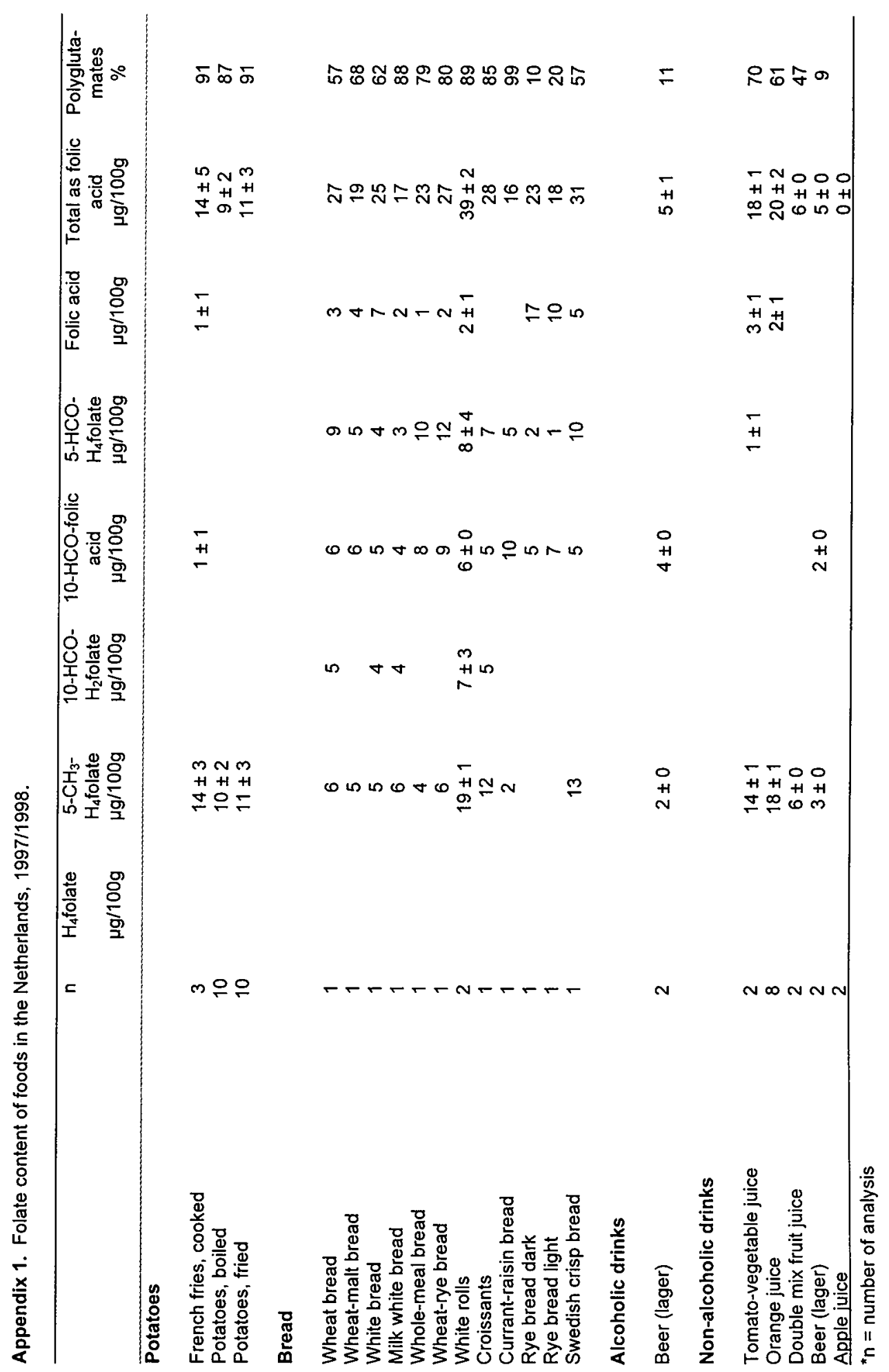




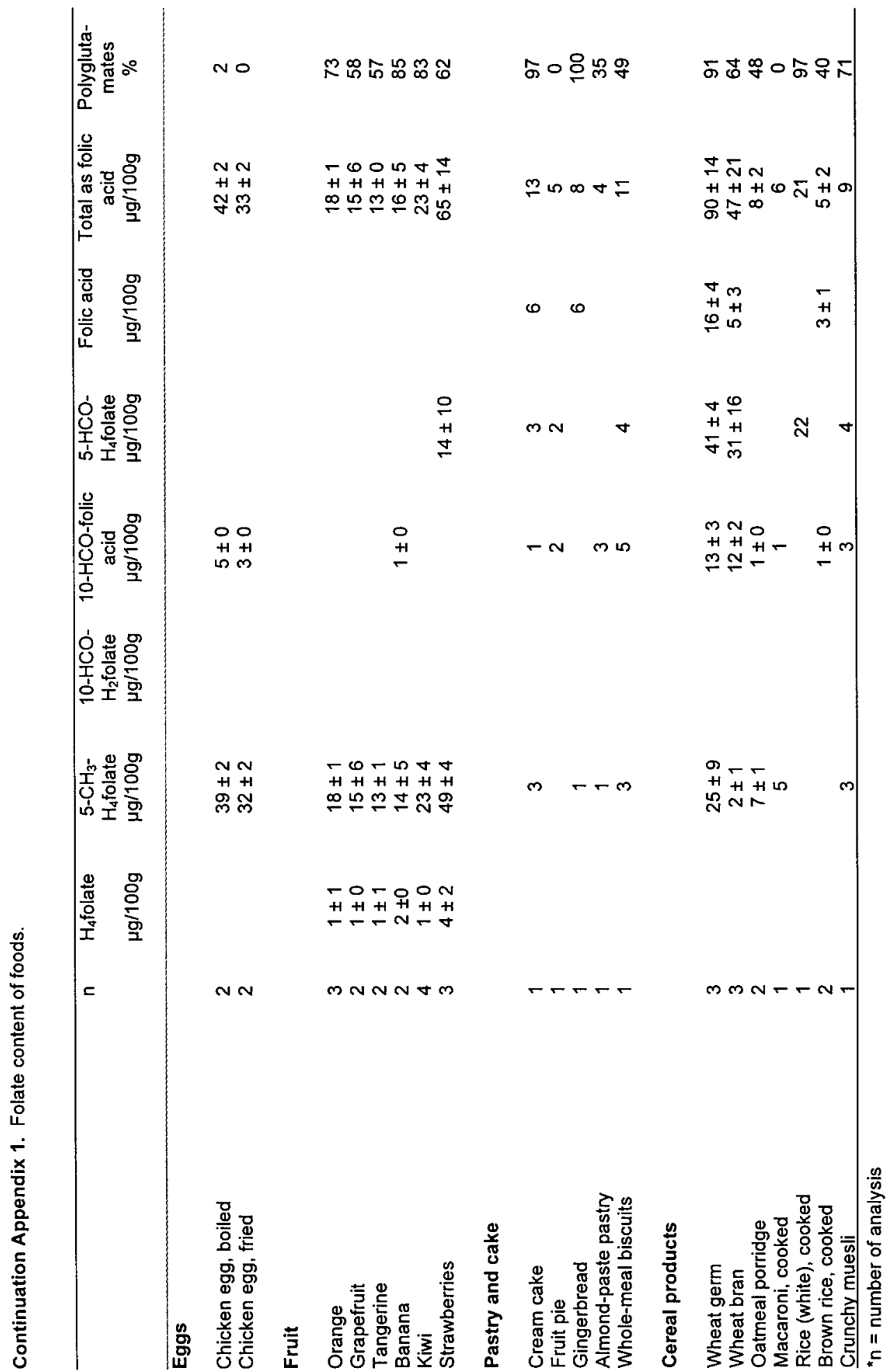




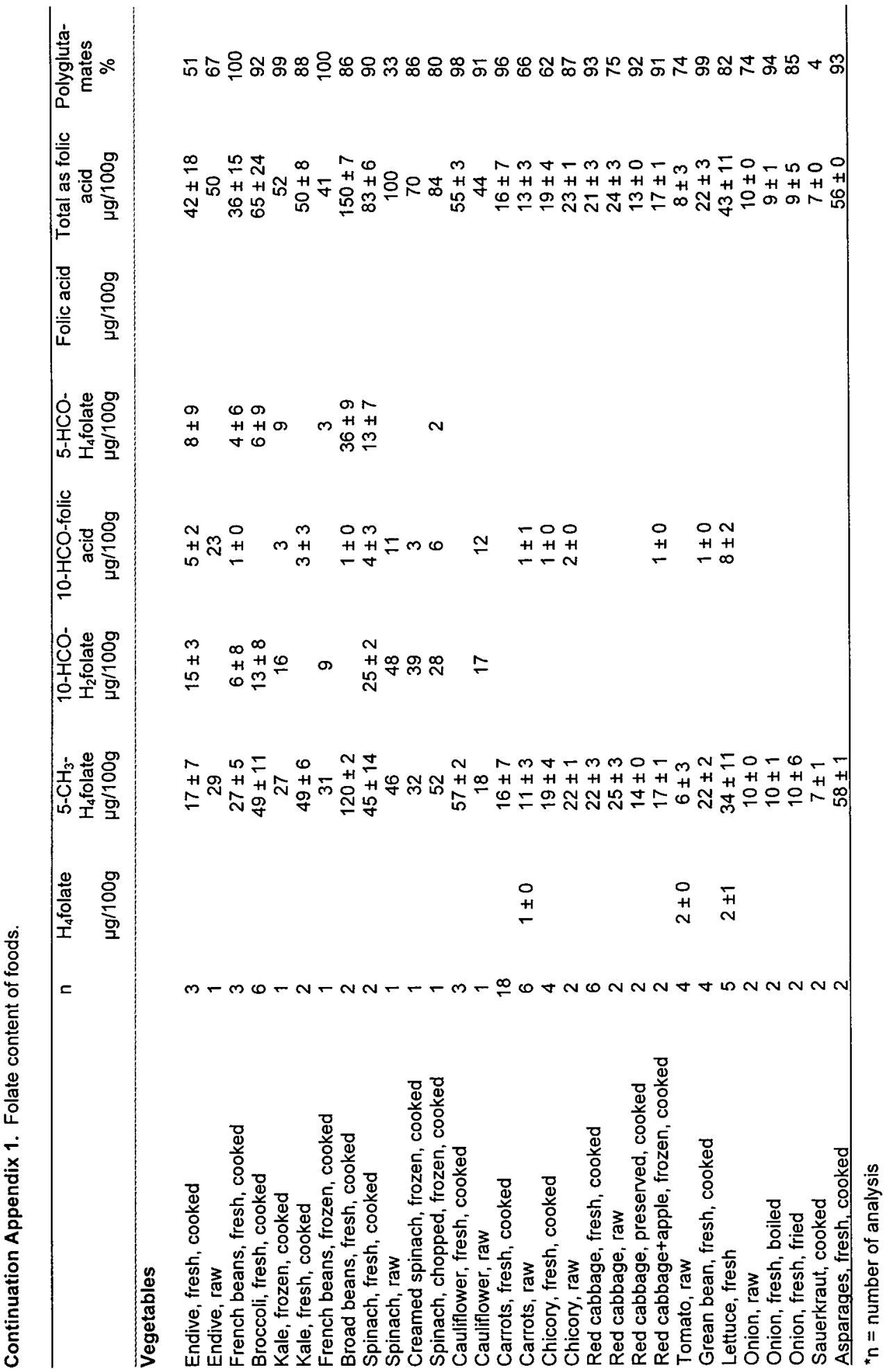




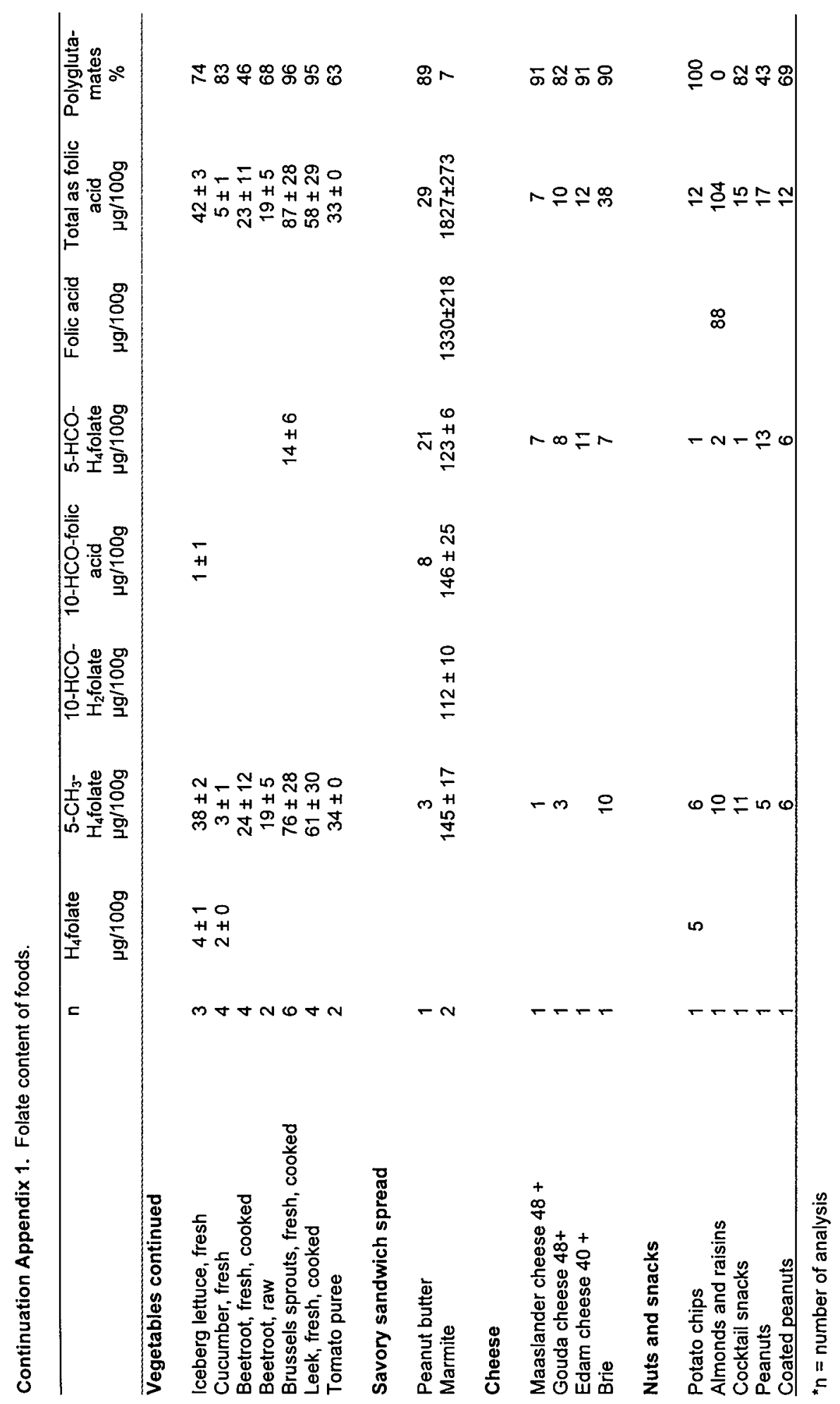




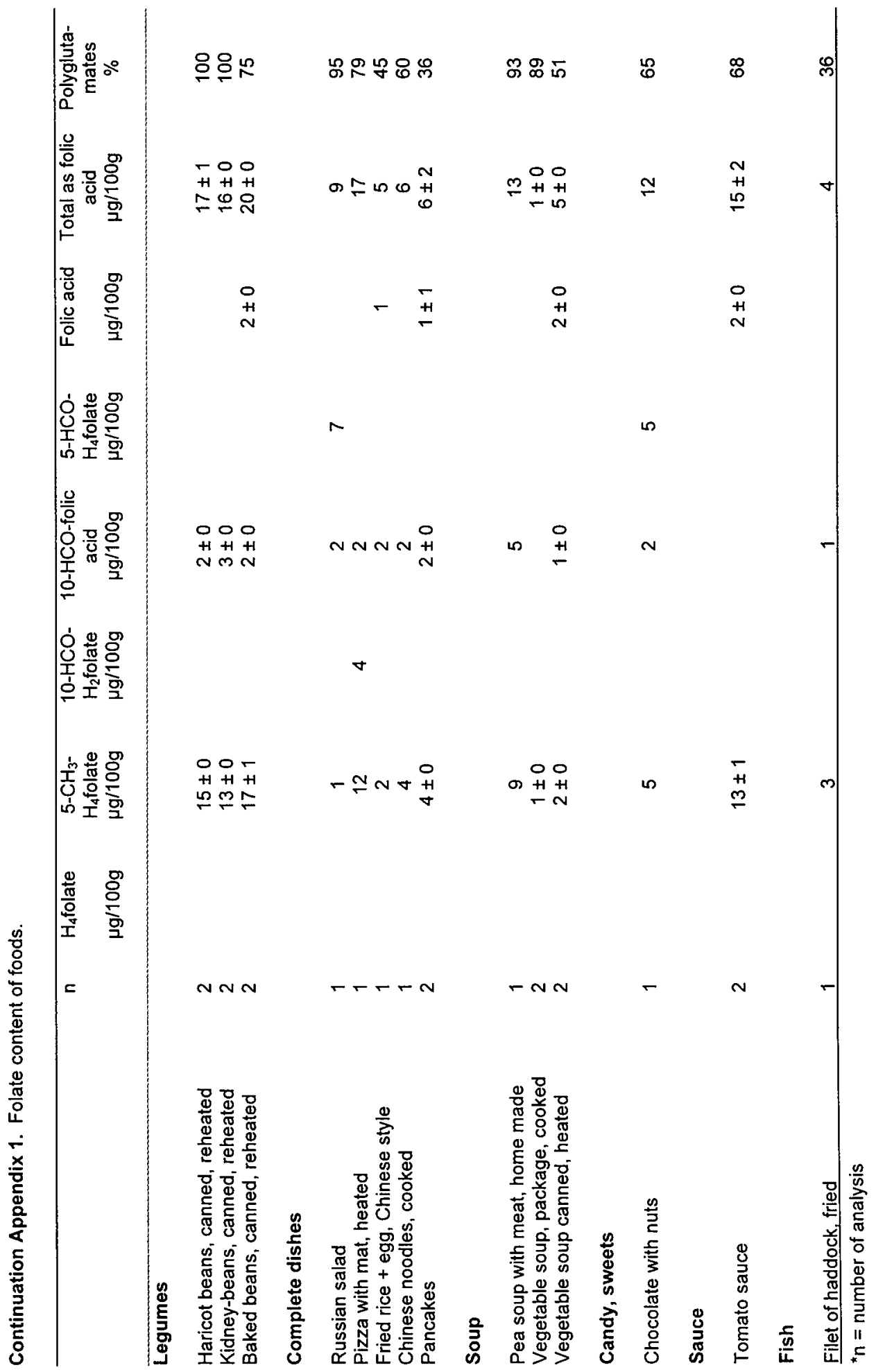




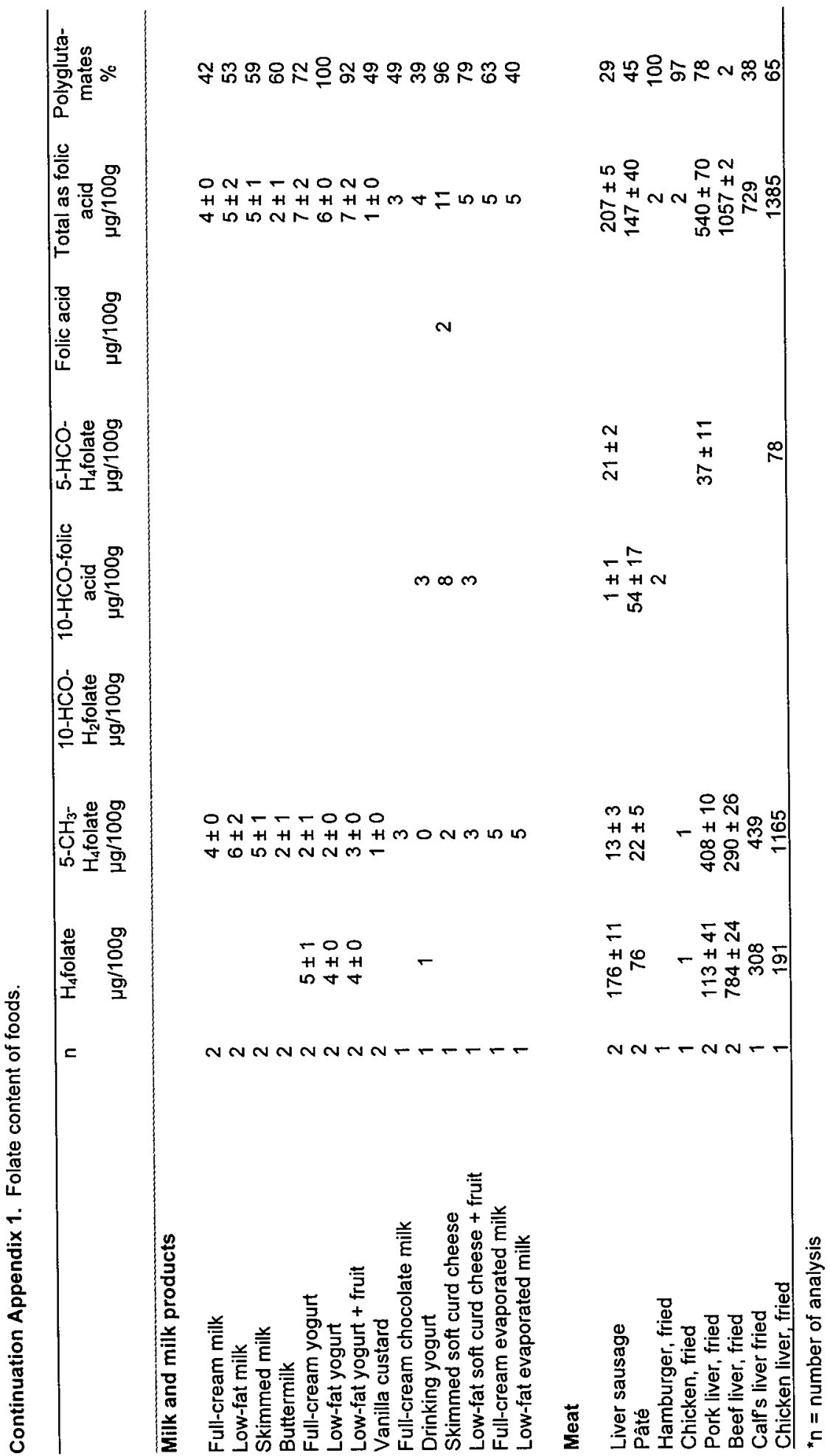




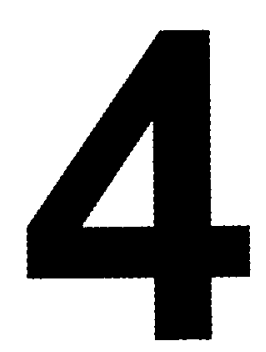

\section{Bioavailability of different types of folate in healthy ileostomy volunteers}

Erik J.M. Konings, Freddy J. Troost, Jacqueline J.M. Castenmiller, Harry H.S. Roomans, Piet A. van den Brandt, Wim H.M. Saris

Submitted for publication 


\section{ABSTRACT}

In spite of various studies, our knowledge on the bioavailability of folate, especially different types of folate in food, remains limited. The present study was designed to determine the bioavailability of folates in healthy ileostomy volunteers $(N=11)$ using a single-dose short-term protocol.

The most important issues in this study concern the deconjugation process as a possible limiting factor in the absorption of folates. The study also attempted to validate the use of the area under the serum response curve (AUC) from food compared to folic acid as a proxy variable for food folate bioavailability.

Based on analysis of test meals and ileostomy effluents, there was no difference in folate absorption between spinach with a mono-/polyglutamate ratio of 40:60 and the same spinach with a 100:0 ratio. Vitamers present in cooked spinach were 5-methyltetrahydrofolate, 10-formyldihydrofolate and 10-formylfolic acid. Their absorption was $89 \%, 88 \%$ and $74 \%$ respectively. Supplemental folic acid was absorbed for $91 \%$. The absolute bioavailability of spinach folate $(78 \%)$ calculated from the difference between folate intake and folate content of ileostomy effluents was not equal to the relative bioavailability $(114 \%)$ calculated from the AUC after consumption of spinach meals in relation to the AUC after consumption of spinach meals in relation to the AUC after consumption of the folic acid supplement.

We conclude that the deconjugation process is not a limiting factor in the absorption of spinach folates. The discrepancy in absorption of spinach folates compared to folic acid was small $(-10 \%)$. Comparing AUCs of food folate versus folic acid in a short-term protocol may not be suitable for assessing food folate bioavailability.

KEY WORDS: Folates, bioavailability, absorption, AUC, spinach. 


\section{INTRODUCTION}

In recent years extra attention is focused on the role of folic acid in neural tube defects, cardiovascular disease via homocysteine and colorectal cancer. Folates are a large family of polyglutamates (usually 5-7 glutamyl residues) of pteroic acid and related analogues, which qualitatively exhibit the biological activity of folic acid. Folate polyglutamates need to be cleaved into folate monoglutamates by pteroylpolyglutamate hydrolase (conjugase), present in the intestinal brush border, before they can be absorbed in the intestine. Average bioavailability of folates from foods has been estimated at about $50 \%$ in a long-term, 92-day controlled metabolic study by Sauberlich et al. (1987). So far, this is thought to be the only food folate bioavailability study for mixed diets. In spite of many studies, our understanding of possible causes of this poor bioavailability remains incomplete.

Reisenauer and Halsted (1987) calculated that the human brush border might contain a large amount of conjugase, which would be able to deconjugate polyglutamates even when consumed in quantities far above the recommended daily intake. Certain food components, such as organic acids in orange juice (Wei et al. 1996, Wei \& Gregory 1998) or dietary fiber (Bailey et al. 1988, Keagy et al. 1988) might influence this deconjugation process. Results of in vitro experiments have indicated that, for instance, spinach components inhibit porcine conjugase (Bhandari and Gregory 1990) and human conjugase (Bhandari \& Gregory 1990, Wei \& Hou 2000). There might be significant differences in the absorption of different folate vitamers (Gregory 1995). Although many studies have investigated the bioavailability of endogenous folate in selected foods using human subjects or animal bioassay procedures (Babu \& Srikantia 1976, Clifford et al. 1990, Tamura \& Stokstad 1973), most methods applied to determine folate bioavailability have procedural or conceptual limitations (Gregory 1995). Results of in vitro or animal studies provide little information on the applicability to the human in vivo situation. Labeled folates have often been used to determine folate bioavailability (Wei et al. 1996, Gregory et al. 1992). The question remains, however, whether these isolated folates are absorbed in the same way as folates in a food matrix. So far, most methods have yielded information regarding the bioavailability of total folate relative to folic acid, rather than the absolute bioavailability of total folate or the various folate vitamers. lleostomy subjects with an intact small intestine and without any recent $(<1$ year) remission of the original disease are pre-eminently suitable for a study of absolute folate absorption, because absorption of folates takes place exclusively in the small intestine (Gregory 1995). Folate absorption cannot be estimated via normal faecal excretion because the presence of microorganisms in the colon will influence folate amounts in faeces.

The present study was designed to determine folate absorption in healthy ileostomy volunteers, using spinach as a food matrix in a short-term protocol. In a 
pilot study to design the present protocol we were able to show that folates in cooked spinach were mainly present as polyglutamates (approx. 85\%), and were equally distributed over the two main folate vitamers; 5-methyltetrahydrofolate (5$\mathrm{CH}_{3}-\mathrm{H}_{4}$ folate) and 10 -formyldihydrofolate $\left(10-\mathrm{HCO}-\mathrm{H}_{2}\right.$ folate). Since the total folate concentration in spinach is high (approx. $100 \mu \mathrm{g} / 100 \mathrm{~g}$ ) it is an excellent source of the various folate vitamers and a suitable vehicle to study the bioavailability of the different folate vitamers from food compared to folic acid. Thus, the purpose of the study was to address the issue of deconjugation of folate vitamers and to examine the bioavailability of the folate vitamers. Furthermore, it provided an opportunity to validate the use of the area under the serum folate response curve (AUC) from food in a single-dose short-term protocol as a suitable proxy variable for food folate bioavailability compared to supplemental folic acid.

\section{MATERIALS AND METHODS}

\section{Subjects}

Twelve ileostomy volunteers were recruited ( 6 men and 6 women). The mean age of the men was 56 y (range: 36-69 y); that of the women 48 y (range: $37-58 y$ ). The mean body mass index of the men was $26.1 \mathrm{~kg} / \mathrm{m}^{2}$ (range: $23.0-27.8 \mathrm{~kg} / \mathrm{m}^{2}$ ); that of the women $26.9 \mathrm{~kg} / \mathrm{m}^{2}$ (range: $20.9-34.7 \mathrm{~kg} / \mathrm{m}^{2}$ ). Reasons for applying ileostomy in subjects varied from colitis ulcerosa $(n=7)$ to polyposis $(n=1)$, Crohn's disease $(n=3)$ or a neurological defect of the pelvic bottom $(n=1)$. In all subjects, no more than $20 \mathrm{~cm}$ of the terminal ileum had been removed and led out onto the anterior abdominal wall as a fistula. All subjects had had their well-functioning ileostomies for 5 years or longer and were not hospitalized at the time of the study. Subjects with Crohn's disease had been in remission for at least 1 year. No medication was used which could affect the folate absorption process, such as anti-inflammatory drugs. There were no indications of malabsorption. Plasma folate levels and red cell blood folate concentrations among ileostomists have been found to be normal (Kennedy et al. 1982, Nilsson et al. 1979). None of the subjects in the present study had serum folate levels below $6.8 \mathrm{nmol} / \mathrm{L}$. Individuals with serum concentrations below this level are considered to be folate deficient (Sauberlich 1995), which might affect the amount of folate absorbed (Pietrzik 1990). One man and one woman smoked. The suitability of each of the volunteers was tested by having them complete a medical questionnaire and through assessment by a gastroenterologist. The protocol was approved by the Maastricht University Hospital Ethical Committee and was fully explained to the participants, who all gave their written informed consent. 


\section{Study design}

In a randomized cross-over design with a wash-out period of 2 weeks, volunteers received a standard meal followed one hour later by a test meal. A standard meal was given in portions every two hours during the test days to prevent increasing blood folate levels due to disturbed enterohepatic circulation as described by Pietrzik et al. (1990) and Cahil et al. (1998). Fasting seems to interrupt the enterohepatic circulation by blocking an potential elimination route for plasma folate. Administering an energetically adequate but folate-free meal during the trial kept this and other potential systems for folate excretion intact. Volunteers came to the laboratory early in the morning after an overnight fast. The standard meal, administered one hour before the test meal and every 2 hours up to 10 hours subsequently, consisted of a mixture of formula diet, soft curd cheese and water containing $155 \mathrm{kcal}$ (15 energy\% protein, 58 energy\% carbohydrates, 27 energy\% fat) and $35 \mathrm{~g}$ milk chocolate as a source of energy ( 5 energy\% protein, 37 energy $\%$ carbohydrates, 58 energy\% fat), resulting in a total intake of $2064 \mathrm{kcal}$ during the experimental day. Subjects were instructed not to consume folate-rich foods, such as liver products, marmite, spinach or supplements, according to a food list, during the 8 days preceding each test day. One hour after the consumption of the first standard meal, one of the three test meals was given (Table 1). In order to keep folate amounts equal, slightly different quantities of spinach were given, to account for folate losses during preparation. Subjects were allowed to drink unlimited amounts of water, tea and coffee (without sugar or milk).

Table 1. Test meals during bioavailability study.

\begin{tabular}{l} 
Test meal \\
Content \\
A \\
\hline
\end{tabular}

On each test day, blood samples were drawn before the first standard meal (fasting blood sample), before the test meal (pre-dose blood sample) and during 9 hours after the consumption of the test meal. 
Immediately after the consumption of the test meal, volunteers were asked to empty their ileostomy bags. From that moment on, these bags were emptied every two hours into a container stored in solid carbon dioxide $\left(-79^{\circ} \mathrm{C}\right)$, during the 9 hours after the consumption of the test meal. After these 9 hours, the volunteers went home, having been instructed not to eat until the next morning and to collect their ileostomy effluents until that time in a container stored in solid carbon dioxide. All frozen ileostomy effluents for each subject were combined and homogenized in liquid nitrogen, yielding the final sample over a $24 \mathrm{~h}$ period after the test meal, which was then used for analysis. The samples were stored at $-20^{\circ} \mathrm{C}$.

To confirm that there was no serum folate enhancement by the standard meal, another 3 ileostomy volunteers completed one test day and consumed all standard meals, but not the test meal.

\section{Test meals}

Fresh spinach was washed and subsequently dried in a kitchen centrifuge, after which it was chopped up in a food processor. All spinach originated from one batch.

Test meal A: chopped spinach was immediately heated in a microwave for 5 minutes at $900 \mathrm{~W}$ and stored at $-20^{\circ} \mathrm{C}$. The chopping process took $15-20$ minutes.

Test meal B: chopped spinach was stored for 24 hours in a refrigerator at $4^{\circ} \mathrm{C}$. After this storage period the spinach was given the same treatment as test meal $A$ : heating in a microwave for 5 minutes at $900 \mathrm{~W}$ and storage at $-20^{\circ} \mathrm{C}$.

Test meal C: a folic acid supplement given as a tablet, containing $500 \mu \mathrm{g}$ of folic acid. The volunteers were instructed to swallow this tablet with some water.

Before the consumption of test meals $A$ and $B$, portions were defrosted for 20 minutes in a microwave and subsequently heated for 5 minutes at $900 \mathrm{~W}$.

\section{Additional measurements}

To compare folate quantities in spinach meals $A$ and $B$ with folate amounts in spinach prepared according to normal household practice, a portion of fresh spinach was washed and cooked without adding additional water for 2 minutes. The whole cooking process took about 10 minutes.

The stability of individual folate vitamers was investigated in human gastric juice and duodenal fluid. The conditions used mimic the stomach and duodenal contents and maximum transit times described by Hollman et al. (1995). Gastric juice (pH = 3.4) and duodenal fluid was taken from fasting subjects. Spinach $(6 \mathrm{~g})$ or a combination of $500-1200 \mathrm{ng}$ of $5-\mathrm{CH}_{3}-\mathrm{H}_{4}$ folate, $10-\mathrm{HCO}-\mathrm{H}_{2}$ folate, 5formyltetrahydrofolate (5-CHO- $\mathrm{H}_{4}$ folate), 10-formyl folic acid (10-HCO-folic acid) and folic acid was incubated with gastric juice $(3 \mathrm{~mL})$ and water $(3$ and $9 \mathrm{~mL}$ respectively) for 2 hours at $37^{\circ} \mathrm{C}$. Spinach $(6 \mathrm{~g})$ or a mixture of standard vitamers as described above was incubated with duodenal fluid $(1.5 \mathrm{~mL}$ ) and water ( 3 and 9 
$\mathrm{mL}$ respectively) for 4 hours at $37^{\circ} \mathrm{C}$. Recoveries of spinach folates and folate standards were calculated after HPLC analysis.

To verify the stability of different folate vitamers during the 2-hour storage in the ileostomy bags at body temperature, ileostomy effluents $(n=2)$ were incubated for 2 hours at $37^{\circ} \mathrm{C}$ with approx. $1-20 \mu \mathrm{g}$ of $5-\mathrm{CH}_{3}-\mathrm{H}_{4}$ folate, $10-\mathrm{HCO}-\mathrm{H}_{2}$ folate, $5-\mathrm{CHO}-$ $\mathrm{H}_{4}$ folate, 10-HCO-folic acid, folic acid and folic acid triglutamate. Recoveries were determined after HPLC analysis. To confirm that no interconversions of different folates occurred during analysis, recoveries of the above vitamers (except folic acid triglutamate) were determined after addition of all vitamers to two separate ileostomy effluent samples, prior to homogenizing in the extraction solvent.

Based on the results of folate analyses of all serum samples, $2 \mathrm{~mL}$ serum was taken from each volunteer at the time of maximum serum folate concentration after the intake of the folic acid supplement, and pooled for HPLC analysis to check for unmetabolized folic acid in the serum because the fluoroimmunoassay method cannot differentiate between folate vitamers.

\section{Analytical methods}

A HPLC method was used to analyze the standard meal, test meals (spinach), ileostomy effluent samples and the pooled serum samples (Konings 1999). Briefly, folates were extracted by homogenizing in a Ches/Hepes buffer ( $\mathrm{pH}$ 7.8) containing ascorbic acid and 2-mercaptoethanol as antioxidants. This homogenate was subjected to heat treatment (10 min in a boiling water bath). A first aliquot was analyzed without addition of any enzymes (treatment 1) to estimate the monoglutamate contents of the samples. In a second aliquot, folate concentrations were quantified after addition of rat plasma conjugase (treatment 2 ) to establish the sum of mono- and polyglutamates. In a third aliquot, folate concentrations were determined after treatment with rat plasma conjugase as well as protease and amylase (treatment 3 ). The difference between the folate amounts assayed in treatments 1 and 2 represents the folate polyglutamate content. The difference between the folate amounts determined in treatments 2 and 3 reflects matrixbound folates. After purification by affinity chromatography, folate monoglutamates were determined using a HPLC method with fluorescence and diode array detection (Konings 1999). All analyses were performed under subdued light. This procedure was used to quantify the levels of the most abundant folate forms naturally present, including $\mathrm{H}_{4}$ folate, $5-\mathrm{CH}_{3}-\mathrm{H}_{4}$ folate, $10-\mathrm{HCO}-\mathrm{H}_{4}$ folate, $5-\mathrm{CHO}-$ $\mathrm{H}_{4}$ folate, 10-HCO-folic acid and folic acid.

The folate content of spinach samples $(n=2)$ was also determined by microbiological analyses (Williams 1984) for comparison with HPLC results. Folate amounts of spinach given to the volunteers were determined in all portions taken from the defrosted and heated spinach just before consumption. Samples were homogenized in liquid nitrogen before analysis. 
An automated fluoroimmunoassay (Wallac Inc, Akron, $\mathrm{OH}$ ), a fast routine method, was used to determine folate amounts in serum samples. This folate assay is a solid phase fluoroimmunoassay based on the competitive reaction between europium-labelled folic acid, and sample folates for a limited amount of binding sites on folate binding protein (FBP). Anti-folate binding protein antibody is first incubated to the anti-mouse IgG coated microtitration plate. In a second incubation, Eu-labelled folate tracer, folate sample or standard, and FBP are added. The FBP is captured by the anti-FBP antibody, while labeled and unlabelled folate compete for binding sites on the FBP in a competitive manner. Eu ions are dissociated from the labeled folate forming highly fluorescent chelates. The fluorescence is inversely proportional to the quantity of folate in the sample.

\section{Statistical analysis}

To verify any presence of folates in ileostomy effluents not originating from the test meals, folates other than supplemental folic acid were determined in ileostomy fluids after the consumption of test meal $\mathrm{C}$ and used as an individual's background level. Absorption of spinach folates was determined on the basis of residual folates in ileostomy fluids, after correcting for the total weight of the ileostomy effluents collected and the folate background levels (Absorption (\%) $=[$ (intake + individual background level - excretion in ileostomy bags)/intake] $\times 100 \%$ ). Absorption of folates from test meals $A$ and $B$ was compared by means of a paired Student's ttest at a significance level of 0.05 . Polyglutamate contents of ileostomy fluids collected after the consumption of test meals $B$ and $C$ were compared by means of a paired Student's t-test at a significance level of 0.05 . Folate concentrations of extracts treated with amylase and protease (treatment 3 ) in the analysis were compared with folate concentrations of extracts that had not been treated with these enzymes (treatment 2) by means of a paired Student's t-test at a significance level of 0.05 .

Area under the serum response curve (AUC) was determined using "CurveExpert" version 1.3 (http://www.ebicom.net/ dhyams/cvxpt.htm). Curves were integrated from each individual pre-dose serum folate level (at hour 1) to the serum folate level at hour 10. AUCs of different test meals were compared by means of a Student's t-test at a significance level of 0.05 .

Pre-dose serum folate levels of all subjects on three different test days were compared by means of ANOVA, using a Bonferroni-corrected P-value of 0.017 . Pre-dose serum folate levels and final serum folate levels 9 hours after the consumption of the test meals were compared by means of a paired Student's ttest at a significance level of 0.05 . Results were expressed as mean $\pm S D$. For statistical analysis, the software SPSS for Windows (version 7.5, SPSS, Chicago, IL) was used.

One of the twelve volunteers was unable to consume the complete portion of test meals $A$ and $B$ and was excluded from the statistical analysis. 


\section{RESULTS}

\section{Spinach}

Results of the spinach folate analysis as well as the folate amounts given to the subjects are shown in Table 2. Spinach prepared according to normal household practice (whole-leaf spinach) contained mainly polyglutamates. When spinach was chopped (test meal A), polyglutamates were partly converted to monoglutamates by endogenous conjugase within the 20 minutes of preparation. When chopped spinach was stored for 24 hours (test meal B), all polyglutamates were converted to monoglutamates. The main folate vitamers in spinach were $5-\mathrm{CH}_{3}-\mathrm{H}_{4}$ folate and $10-\mathrm{HCO}-\mathrm{H}_{2}$ folate, in a proportion of approx. 1:1. After 24 hours of storage, a large amount of $10-\mathrm{HCO}-\mathrm{H}_{2}$ folate was oxidized to $10-\mathrm{HCO}$-folic acid.

Analyses by HPLC and microbiology yielded comparable total folate results for spinach.

\section{Absorption of folates from small intestine content.}

Based on analysis of folate concentrations in the ileostomy effluents and spinach consumed, folate amounts absorbed from test meals A, B and C were 316,309 and $454 \mu \mathrm{g}$, respectively. These amounts correspond with $73 \pm 21 \%, 85 \pm 18 \%$ and $91 \pm 5 \%$ of folate intake, respectively. The higher absorption of folates from test meal B compared to that from test meal A was not statistically significant. The mean folate absorption from test meals $A$ and $B(79 \%)$ was significantly lower $(P=0.02)$ than the absorption from test meal $C(91 \%)$.

The absorption of the two most important monoglutamates from test meal A (5$\mathrm{CH}_{3}-\mathrm{H}_{4}$ folate and $10-\mathrm{HCO}-\mathrm{H}_{2}$ folate) was $85 \pm 28 \%$. The absorption of the two most important polyglutamates from test meal $\mathrm{A}\left(5-\mathrm{CH}_{3}-\mathrm{H}_{4}\right.$ folate and $10-\mathrm{HCO}-\mathrm{H}_{2}$ folate) was $72 \pm 46 \%$. There was no significant difference in the absorption of these monoand polyglutamates from test meal $\mathrm{A}$. The mean absorption of all mono- and polyglutamates from test meal $A$ were 81 and $69 \%$ respectively (NS). The mean absorption of $5-\mathrm{CH}_{3}-\mathrm{H}_{4}$ folate monoglutamate and $10-\mathrm{HCO}-\mathrm{H}_{2}$ folate monoglutamate from test meal B were $89 \pm 25 \%$ and $88 \pm 17 \%$ respectively (NS). The absorption of $10-\mathrm{HCO}$-folic acid from test meal $\mathrm{B}$ was $74 \pm 23 \%$, which was not significantly different from the mean absorption of $5-\mathrm{CH}_{3}-\mathrm{H}_{4}$ folate and $10-\mathrm{HCO}-\mathrm{H}_{2}$ folate monoglutamate from this spinach meal. 
Table 2. Results of folate analysis in spinach.

\begin{tabular}{|c|c|c|c|}
\hline & $\begin{array}{l}\text { Spinach cooked } \\
\text { according to normal } \\
\text { household practice }\end{array}$ & $\begin{array}{l}\text { Spinach of test } \\
\text { meal A }\end{array}$ & $\begin{array}{l}\text { Spinach of test } \\
\text { Meal } B\end{array}$ \\
\hline $\begin{array}{l}\text { Total folates according to HPLC } \\
\text { analysis }(\mu \mathrm{g} / 100 \mathrm{~g})\end{array}$ & 119 & $148 \pm 1$ & $129 \pm 6$ \\
\hline $\begin{array}{l}\text { Total folates according to } \\
\text { microbiological analysis } \\
(\mu \mathrm{g} / 100 \mathrm{~g})\end{array}$ & 146 & $148 \pm 3$ & $141 \pm 4$ \\
\hline $\begin{array}{l}\text { Mono-/polyglutamate ratio } \\
\text { in spinach }\end{array}$ & $10: 90$ & $40: 60$ & $100: 0$ \\
\hline $\begin{array}{l}\text { Total spinach folate amounts given } \\
\text { to subjects }(\mu \mathrm{g}) \text { of which: }\end{array}$ & & $436 \pm 42^{3}$ & $362 \pm 23^{4}$ \\
\hline \multicolumn{4}{|l|}{ Monoglutamates } \\
\hline 5- $\mathrm{CH}_{3}-\mathrm{H}_{4}$ folate & & $99 \pm 2$ & $111 \pm 12$ \\
\hline $10-\mathrm{HCO}-\mathrm{H}_{2}$ folate & & $58 \pm 14$ & $105 \pm 30$ \\
\hline 10-HCO-folic acid & & $12 \pm 2$ & $106 \pm 11$ \\
\hline 5- $\mathrm{CHO}-\mathrm{H}_{4}$ folate & & $5 \pm 8$ & $40 \pm 4$ \\
\hline \multicolumn{4}{|l|}{ Polyglutamates } \\
\hline 5- $\mathrm{CH}_{3}-\mathrm{H}_{4}$ folate & & $72 \pm 8$ & 0 \\
\hline 10- $\mathrm{HCO}-\mathrm{H}_{2}$ folate & & $150 \pm 39$ & 0 \\
\hline 10-HCO-folic acid & & $13 \pm 4$ & 0 \\
\hline 5-CHO- $\mathrm{H}_{4}$ folate & & $27 \pm 15$ & 0 \\
\hline
\end{tabular}

\footnotetext{
${ }^{1}$ All folate amounts in the table are expressed as folic acid.

${ }^{2}$ This spinach was not given to volunteers, but used for comparison between HPLC and microbiological analysis.

${ }^{3}$ Fresh spinach was washed, dried and chopped, immediately heated in a microwave for 5 minutes at $900 \mathrm{~W}$ and stored at $-20^{\circ} \mathrm{C}$. Before consumption, portions were defrosted and subsequently heated for 5 minutes at $900 \mathrm{~W}$.

${ }^{4}$ Fresh spinach was washed, dried, chopped and stored for 24 hours in a refrigerator at $4^{\circ} \mathrm{C}$. After storage the spinach was heated in a microwave for 5 minutes at $900 \mathrm{~W}$ and kept at $-20^{\circ} \mathrm{C}$. Before consumption, portions were defrosted and subsequently heated for 5 minutes at $900 \mathrm{~W}$.
} 


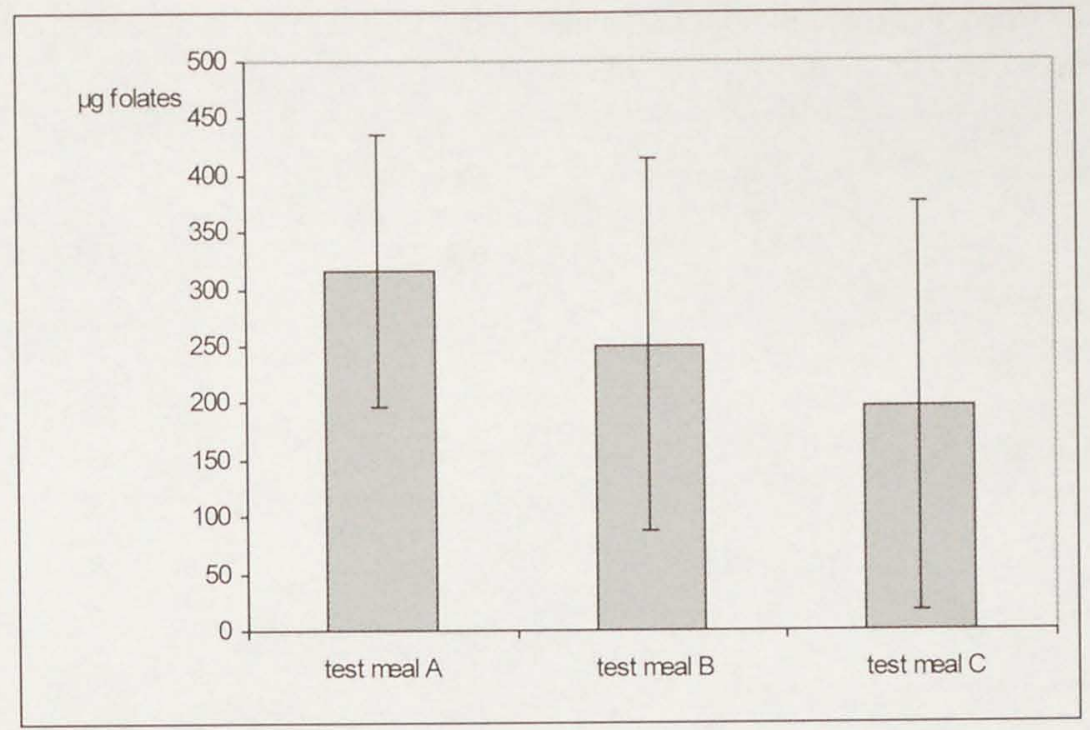

Figure 1. Mean folate amounts in ileostomy fluids ( $\pm S D$ ) collected over a period of 24 hours after consumption of various test meals. For test meal $\mathrm{C}$, remaining supplemental folic acid $(46 \mu \mathrm{g})$ is not included. Therefore test meal $C$ represents the mean individual background level.

Figure 1 compares total folate amounts in ileostomy fluids collected after consumption of test meals $A$ and $B$ with folate amounts in ileostomy fluid after the consumption of test meal $\mathrm{C}$, excluding nonabsorbed folic acid from the supplement. The contribution of ingested folates from the standard meal during the entire day was relatively small $(31 \mu \mathrm{g})$ compared to ingested spinach folates (362$436 \mu \mathrm{g}$ ). A relatively high amount of folates other than folic acid was found as a background level in ileostomy fluids from test meal C: $197 \pm 175 \mu \mathrm{g} / 24 \mathrm{~h}$. The monoglutamate:polyglutamate ratio of this $24 \mathrm{~h}$ collected fluid was $11: 89$, containing $37 \% 5-\mathrm{CH}_{3}-\mathrm{H}_{4}$ folate polyglutamate and $44 \% \quad 10-\mathrm{HCO}-\mathrm{H}_{2}$ folate polyglutamate. Although no polyglutamates were given in test meals $B$ and $C$, excretion of these folates in both ileostomy fluids was high and there was no significant difference between meals $B$ and $C(P=0.97)$. The level of polyglutamates in ileostomy effluent from meal $B$ was $171 \pm 169 \mu \mathrm{g} / 24 \mathrm{~h}$, compared to $172 \pm 166 \mu \mathrm{g} / 24 \mathrm{~h}$ in the ileostomy effluent from meal $\mathrm{C}$.

\section{Incubation of folates with gastrointestinal fluids in vitro}

Recoveries of spinach folates and standard folate vitamers determined after in vitro incubation with gastric juice and duodenal fluid are summarized in Table 3 . The mean recovery of different folates incubated with gastric juice ranged from $88 \%$ for $10-\mathrm{HCO}-\mathrm{H}_{2}$ folate to $112 \%$ for $5-\mathrm{HCO}-\mathrm{H}_{4}$ folate. Mean recovery of folates incubated with duodenal fluid ranged from $84 \%$ for $5-\mathrm{CH}_{3}-\mathrm{H}_{4}$ folate to $106 \%$ for $10-\mathrm{HCO}$ $\mathrm{H}_{2}$ folate. No deconjugation of spinach polyglutamates occurred during incubation. 
Table 3. Recovery rates of spinach folates and folate standards determined after in vitro incubation with gastric and duodenal juice ${ }^{1}$.

\begin{tabular}{|c|c|c|c|}
\hline & $\begin{array}{c}\text { Folate amounts } \\
\text { incubated } \\
\mu g\end{array}$ & $\begin{array}{c}\text { Recovery after } \\
\text { incubation with gastric } \\
\text { juice for } 2 \mathrm{hrs} \text { at } 37^{\circ} \mathrm{C} \text {. } \\
\%\end{array}$ & $\begin{array}{c}\text { Recovery after incubation } \\
\text { with duodenal fluid for } 4 \\
\text { hrs at } 37^{\circ} \mathrm{C} \text {. } \\
\%\end{array}$ \\
\hline 5- $\mathrm{CH}_{3}-\mathrm{H}_{4}$ folate & 0.5 & $91 \pm 2$ & $84 \pm 3$ \\
\hline $10-\mathrm{HCO}-\mathrm{H}_{2}$ folate & 1.2 & $88 \pm 0$ & $106 \pm 4$ \\
\hline 5-CHO- $\mathrm{H}_{4}$ folate & 0.5 & $112 \pm 25$ & $103 \pm 7$ \\
\hline 10-HCO-folic acid & 0.7 & $92 \pm 2$ & $90 \pm 2$ \\
\hline folic acid & 0.6 & $99 \pm 2$ & $93 \pm 5$ \\
\hline spinach & 4.2 & $104 \pm 4$ & $96 \pm 2$ \\
\hline
\end{tabular}

${ }^{1}$ Values are mean $\pm S D$.

\section{Incubation of folates with ileostomy effluents ex vivo}

Results of the stability analyses, to mimic the conditions when an ileostomy bag is carried on the body for maximal 2 hours, are shown in Table 4. The mean standard recovery of folates added prior to analysis ranged from $68 \%$ for $5-\mathrm{HCO}-\mathrm{H}_{4}$ folate to $100 \%$ for folic acid.

Recovery of $5-\mathrm{CH}_{3}-\mathrm{H}_{4}$ folate after incubation with ileostomy fluids for 2 hours was low, $36 \%$, whereas the recovery of $10-\mathrm{HCO}-\mathrm{H}_{2}$ folate was high: $228 \%$. No deconjugation of folic acid triglutamate was found after incubation with ileostomy fluids.

Treatment of sample extracts with amylase and protease in the analysis of ileostomy effluents yielded $10 \%$ higher folate concentrations $(P<0.0001)$ than those found in extracts not treated with these enzymes. 
Table 4. Results of folate recoveries determined after addition of folates to ileostomy fluids just before addition of homogenizing buffer for analysis and after addition of folates before ex vivo incubation with ileostomy fluids for 2 hours at $37^{\circ} \mathrm{C}^{1}$.

$\begin{array}{ccc}\text { Folate amounts added } & \begin{array}{c}\text { Recovery after } \\ \text { addition of folates to ileo- of folates with ileostomy } \\ \text { stomy fluids before } \\ \text { analysis } \\ \%\end{array} & \begin{array}{c}\text { Recovery after incubation } \\ \text { fluids for } 2 \text { hours at } 37^{\circ} \mathrm{C} .\end{array} \\ \mu \mathrm{gg} & \%\end{array}$

$\begin{array}{lccc}5-\mathrm{CH}_{3}-\mathrm{H}_{4} \text { folate } & 1.8 & 84 \pm 14 & 36 \pm 29 \\ 10-\mathrm{HCO}-\mathrm{H}_{2} \text { folate } & 3.0 & 82 \pm 8 & 228 \pm 15 \\ 5-\mathrm{CHO}-\mathrm{H}_{4} \text { folate } & 0.7 & 68 \pm 9 & 94 \pm 7 \\ 10-\mathrm{HCO} \text {-folic acid } & 1.5 & 84 \pm 4 & 104 \pm 10 \\ \text { folic acid } & 1.1 & 100 \pm 6 & 106 \pm 14 \\ \text { PteGlu } & 20 & \text { not determined } & \text { no deconjugation }\end{array}$

${ }^{\top}$ Values are mean $\pm S D$.

\section{Serum folate levels}

Serum folate responses to test meals are shown in Figure 2. Maximum serum folate concentration after consumption of test meal $A, B$ and $C$ were significantly higher than pre-dose serum folate concentrations $(P<0.01)$. Maximum serum folate concentrations were reached 45 minutes after the consumption of test meals $A$ and B. Mean folate concentrations were $30.7 \pm 24.3 \mathrm{nmol} / \mathrm{L}$ for test meal $A$ and $30.7 \pm$ $23.1 \mathrm{nmol} / \mathrm{L}$ for test meal $\mathrm{B}$. The maximum serum concentration for test meal $\mathrm{C}$ $(25.7 \pm 22.9 \mathrm{nmol} / \mathrm{L})$ was reached 2 hours after consumption. There was no difference in pre-dose serum folate levels between the three test days of each subject: $1 ; 17.7 \pm 18.9 \mathrm{nmol} / \mathrm{L}, 2 ; 18.2 \pm 15.8 \mathrm{nmol} / \mathrm{L}, 3 ; 18.5 \pm 21.3 \mathrm{nmol} / \mathrm{L}$. Also no significant differences are observed between pre-dose serum folate levels and final serum folate levels 9 hours after consumption of test meal $A, B$ or $C$. The three subjects who consumed only the standard meal had final folate levels ( 7.5 $\mathrm{nmol} / \mathrm{L})$ which were significantly lower than the pre-dose concentration $(8.5 \mathrm{nmol} / \mathrm{L})$ $(P<0.001)$.

Mean AUCs for test meals A, B and C were $181 \pm 151,181 \pm 167$ and $202 \pm$ 178 respectively, with no significant differences among them.

\section{Determination of unmetabolized folic acid in serum}

Serum samples at maximum concentration levels after the intake of supplemental folic acid were pooled and analyzed by HPLC. The distribution of the vitamers in serum was as follows: $5-\mathrm{CH}_{3}-\mathrm{H}_{4}$ folate: $82 \%$; folic acid: $16 \% ; 10-\mathrm{HCO}$-folic acid: $2 \%$. 


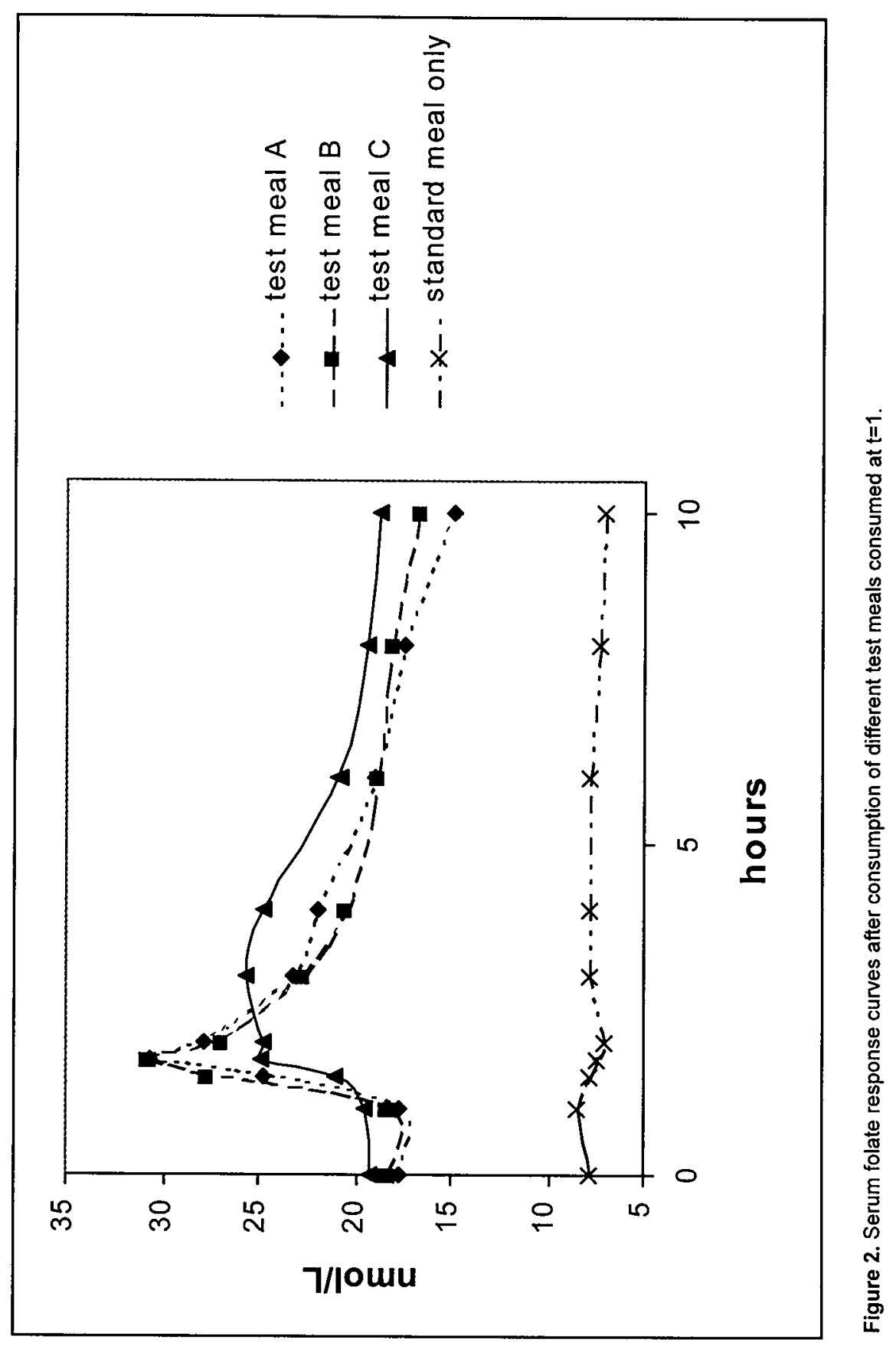




\section{DISCUSSION}

Conjugase, which is present in vegetables and deactivated by heat treatment, is able to conjugate folate polyglutamates and is activated after disruption of the matrix by chopping and homogenization (Leichter et al. 1979). This principle was used in the present study for preparation of the spinach samples. Subjects received a portion of spinach containing natural food folate polyglutamates and a portion of the same spinach containing only natural food folate monoglutamates. Absorption differences between mono- and polyglutamates, if any, would thus be revealed without the confounding effects of food matrix, additions or synthetic folates.

As expected, tetrahydrofolate was not present in cooked spinach because of its thermal lability. 10-Formyltetrahydrofolate cannot be determined by the HPLC method but, if present in fresh spinach, would completely be oxidized to 10formyldihydrofolate and/or 10-formylfolic acid during preparation. This is supported by the finding that similar amounts of total folate were determined in cooked spinach by microbiological and HPLC analysis. This strongly suggests that no other folate vitamers were present in the spinach given to the volunteers.

The folate absorption from spinach was high. Although the absorption from the folic acid supplement was significantly higher, the difference was only $10 \%$. The similarity in the absorption of poly- and monoglutamates from test meals $\mathrm{A}$ and $\mathrm{B}$ suggests that food components in spinach do not influence the deconjugation process. In vitro experiments have shown inhibition of conjugase activity by spinach components (Wei \& Hou 2000, Bhandari \& Gregory 1990). If these results can be extrapolated to the in vivo situation, this inhibition apparently has no effect on the absorption of folates. Many studies have determined the relative bioavailability of polyglutamates versus corresponding monoglutamates, using isotopically labeled or nonlabeled synthetic folates, and

found it to range from $50-100 \%$ (Gregory 1995). The results of the present study showed no differences between the absorption of mono- and polyglutamates from spinach.

The present study indicated a high degree of absorption of 10-HCO-folic acid and $10-\mathrm{HCO}-\mathrm{H}_{2}$ folate $(>90 \%)$ compared to the absorption of folic acid. Each of these folates contributes to overall folate activity (Baggott \& Johanning 1999, Baggott et al. 1995, Gregory et al. 1984, Spies at al. 1948)

24-Hours collection of ileostomy effluents after consumption of test meals was sufficient because total transit time of stomach and small intestine is approximately 7-9 hours. A relatively large amount of folates was determined in ileostomy effluents collected on the test days when subjects received the folic acid supplement only as a folate source. This synthetic folic acid is not a common vitamer in humans and showed good stability in gastric and duodenal juices. 
Therefore, the other folate vitamers present in these ileostomy effluents can be considered as individual background levels. Folate polyglutamates were the main vitamers present. It has been shown that $5-\mathrm{CH}_{3}-\mathrm{H}_{4}$ folate monoglutamate is largely secreted in bile to the small intestine, where it is reabsorbed, providing an enterohepatic circulation (Steinberg 1984, Steinberg et al. 1979). Folate polyglutamates folates might have ended up in the ileostomy effluents via intestinal enterocytes. Halsted (1991) hypothesized that after deconjugation of dietary polyglutamates to monoglutamates by brush-border folate hydrolase, and transport across the brush border into the enterocyte, folate polyglutamates are synthesized intracellularly by folate synthetase.

Enterocytes are formed in crypts at the base of the small intestinal villus and migrate along the crypt toward the villus tip, from where they are sloughed into the lumen after a period of 4-7 days. Cell contents, including polyglutamates, might be secreted holocrine into the ileostomy effluent (Magee \& Dalley 1986). The presence of $5-\mathrm{CH}_{3}-\mathrm{H}_{4}$ folate polyglutamate and $10-\mathrm{HCO}-\mathrm{H}_{2}$ folate polyglutamate in ileostomy effluents cannot be explained on the basis of the existing knowledge. After incubating ileostomy effluents with folates it was found that $5-\mathrm{CH}_{3}-\mathrm{H}_{4}$ folate was converted to $10-\mathrm{HCO}-\mathrm{H}_{4}$ folate. This conversion did not take place during analysis, as the addition of folates to ileostomy effluents prior to analysis yielded good recoveries. Conversions of $5-\mathrm{CH}_{3}-\mathrm{H}_{4}$ folate in $10-\mathrm{HCO}-\mathrm{H}_{2}$ folate probably occurred only in the experimental circumstances of the in vitro situation and did not influence bioavailability results because there was no difference in bioavailability results because there was no difference in bioavailability between the two spinach samples, if calculated on the basis of AUC units per microgram of folate/folic acid ingested (for test meal A: 103\%, test meal B: $124 \%$ ) and if calculated on the basis of AUC units per microgram of folate/folic acid absorbed (test meal $A: 129 \%$, test meal B $132 \%)$. Conversion of $5-\mathrm{CH}_{3}-\mathrm{H}_{4}$ folate into $10-\mathrm{HCO}-\mathrm{H}_{2}$ folate possibly occurred by enzymes, which were released from the enterocytes when ileostomy effluents were thawed. Incubation of ileostomy effluent with folic acid triglutamate revealed that there was no conjugase activity in digestive fluids.

lleostomy fluids have an unique microbial ecology that is different from the normal microflora of the small and large intestines (Hill 1976). While aerobes are present in equal numbers as in faeces, anaerobic counts are lower (5 logs) in ileostomy effluent than in faeces (Hill 1976). Herbert et al. (1984) determined 200 $\mu \mathrm{g}$ of folates ( $n=6$, range $57-577 \mu \mathrm{g} / 24 \mathrm{~h}$ ) in 24 -hour human stools. They hypothesized that it was enteric bacteria that produced these amounts. It is more likely that the folate amounts originated from the enterocytes, as the same mean and range of folate amounts were determined in the 24-hour ileostomy effluents. This is corroborated by the fact that the numbers of anaerobic bacteria, which are major folate producers, are considerably lower in ileostomy effluents than in faeces, especially in view of the frequent exchange of bags in our protocol. 
Furthermore, there were no significant differences in folate polyglutamate amounts in ileostomy effluents collected for each subject on different days after the consumption of test meals $B$ and $C$, suggesting no intervention of bacteria. The absence of any significant differences justified the correction of each 24-hour ileostomy effluent by the 24-hour folate background levels separately for each subject.

The difference between pre-dose serum folate levels of subjects who had only the standard meals, and subjects who consumed the test meals, was based on coincidence. One person, who consumed the test meals, used a vitamin B supplement until 8 days preceding each test day and had a serum pre-dose level of $73 \mathrm{nmol} / \mathrm{L}$. This influenced the mean serum pre-dose level of all subjects. However, this high level did not affect mean absorption and AUC results.

The maximum serum folate concentration was reached 45 minutes after the consumption of test meals $A$ and $B$. Frequent sampling around this period is of importance to determine an exact AUC. In a bioavailability study by PrinzLangenohl et al. (1999) only two blood samples were taken in the first two hours after spinach consumption. This would definitely have underestimated the AUC. The course of the appearance of folic acid in serum is apparently very different from that of spinach folates, probably because folic acid first has to be reduced to $\mathrm{H}_{4}$ folate, followed by methylation, before entering the portal blood (Gregory 1995). This takes time, resulting in a broader and flatter curve. Additionally, the intake as a whole tablet could have led to delayed absorption. This is not likely, however, since Prinz-Langenohl et al. (1999) found a comparable delayed maximum in the serum response curve when folic acid was administered in the form of a solution.

It is evident that AUCs after the intake of test meals $A$ and $B$ should be the same because equal amounts of folates were absorbed from the small intestine content. It is not clear why the AUC from the intake of spinach was not significantly lower than that from the folic acid supplement. According to the amount of folic acid/folates absorbed, the AUC from the supplement was expected to be approximately $45 \%$ higher than the AUCs from spinach. This suggests a metabolic difference between uptake and clearance of dietary folates and synthetic folic acid. This suggestion is supported by the fact that unmetabolized folic acid was found in the serum. Kelly et al. (1997) already reported this phenomenon. It is evident from Figure 2 that the clearance mechanism of supplemental folic acid was different from that of spinach folates. Supplemental folic acid remained in the blood circulation for a longer period of time, which might result in misinterpretations of relative food folate bioavailability when too few blood samples are taken. Results from this study revealed that the absolute bioavailability of spinach folate $(78 \%)$ calculated from the difference between folate intake and folate content of ileostomy effluents was not equal to the relative bioavailability (114\%), calculated from AUCs after consumption of spinach meals in relation to AUCs after consumption of the 
folic acid supplement. This means that comparing AUCs of food folate versus supplemental folic acid may not be suitable for assessing relative food folate bioavailability. It would be interesting to compare the spinach AUCs with an AUC after the intake of $5-\mathrm{CH}_{3}-\mathrm{H}_{4}$ folate, the most common natural source of folate.

In summary, this is the first study showing absorption of various naturally occurring food folates in absolute amounts. The ileostomy model is a suitable method for studying absorption processes. The study revealed excellent absorption of folates from spinach, resulting in a significant enhancement of serum folate concentrations. The deconjugation process is apparently not a limiting factor in the absorption process of spinach folates. An important observation is that the serum folate curve after the intake of supplemental folic acid differs from the serum folate curves after the intake of spinach, suggesting that the relative food folate bioavailability based on serum folate concentrations cannot be assessed with the single-dose short-term protocol used in the present study. Synthetic folic acid is metabolized differently from the natural dietary folates.

\section{ACKNOWLEDGEMENTS}

We would like to thank H.H.P. Franssen of the Inspectorate for Health Protection in 's-Hertogenbosch for his assistance with the preparation of the test meals and the analyses of ileostomy effluents. Thanks are due to K.H. van het Hof of Unilever Health Institute the Netherlands for assistance with the design of this study, as well as to C.G. Blonk and C. van Tuijl of Unilever Health Institute for their practical assistance during the trial. R-J.M. Brummer of the University Hospital Maastricht provided valuable assistance and supplied the duodenal fluid. And last but not least, we are most grateful to all volunteers for their interest, enthusiasm and perseverance in completing the entire study.

\section{REFERENCES}

Babu S, Srikantia SG. Availability of folates from some foods. Am J Clin Nutr 1976;29:376-9.

Baggott JE, Johanning GL, Branham KE, Prince CW, Morgan SL, Eto I, Vaughn WH. Cofactor role for 10-formyldihydrofolic acid. J Biochem 1995;308:1031-6.

Baggott JE, Johanning GL. 10-Formyl-dihydrofolic acid is bioactive in human leukemia cells. J Nutr 1999;129:1315-8.

Bailey LB, Barton LE, Hillier SE, Cerda JJ. Bioavailability of mono and polyglutamyl folate in human subjects. Nutr Rep Int 1988;38,3:509-18.

Bhandari SD, Gregory JF III. Inhibition by selected food components of human and porcine intestinal pteroylpolyglutamate hydrolase activity. Am J Clin Nutr 1990;51:87-94.

Cahill E, Mcpartlin J, Gibney MJ. The effects of fasting and refeeding healthy volunteers on serum folate levels. Internat J Vit Nutr Res 1998;68:142-5.

Clifford AJ, Jones AD, Bills ND. Bioavailability of folates in selected foods incorporated into amino-acid based-diets fed to rats. J Nutr 1990;120:1640-7. 
Gregory JF III, Ristow KA, Sartain DB, Damron BL. Biological activity of the folacin oxidation products 10-formylfolic acid and 5-methyl-5,6-dihydrofolic acid. J Agric Food Chem 1984;32:1337-42.

Gregory JF III, Bhandari SD, Bailey LB, Toth JP, Baumgartner TG, Cerda JJ. Relative bioavailability of deuterium-labeled monoglutamyl tetrahydrofolates and folic acid in human subjects. Am J Clin Nutr 1992;55:1147-53.

Gregory JF III. The bioavailability of folate. In: Bailey L, ed. Folate in health and disease. M. Dekker, New York, NY. 1995:195-235.

Halsted CH. Jejunal brush-border folate hydrolase, a novel enzyme. West J Med 1991;155:605-9.

Herbert V, Drivas G, Manusselis C, Mackler B., Eng J, Schwartz E. Are colon bacteria a major source of cobalamin analogues in human tissues? 24-hr stool contains only about $5 \mu \mathrm{g}$ of cobalamin but about $100 \mu \mathrm{g}$ of apparent analogue (and $200 \mu \mathrm{g}$ of folate). Trans Assoc Am Physicians 1984;97:161-71.

Hill GL. lleostomy: surgery, physiology \& management. Grune \& Stratton, Inc, New York 1976: 78.

Hollman PCH, Vries JHM de, van Leeuwen SD, Mengelers MJB, Katan MB. Absorption of dietary glycosides and quercetin in healthy ileostomy volunteers. Am J Clin Nutr 1995:62:1276-82.

Keagy PM, Shane B, Oace SM. Folate bioavailability in humans: effects of wheat bran and beans. Am J Clin Nutr 1988:47: 80-8.

Kelly P, McPartlin J, Goggins M, Weir DG, Scott JM. Unmetabolized folic acid in serum: acute studies in subjects consuming fortified food and supplements. Am J Clin Nutr 1997;65:1790-5.

Kennedy HJ, Callender ST. Truelove SC, Warner GT. Haematological aspects of life with an ileostomy. Br J Haematol 1982;52:445-54.

Konings EJM. A validated LC method for the determination of folates in vegetables, milk powder, liver and flour. JAOAC int 1999;82,1:119-27.

Leichter J, Landymore AF, Krumdieck CL. Folate conjugase activity in fresh vegetables and its effect on the determination of free folate content. Am J Clin Nutr 1979;32:92-5.

Magee DF, Dalley II AF. Digestion and the structure and function of the gut. Karger, Basel, Switserland 1986:218-9.

Nilsson LO, Andersson H, Hultén L, Jagenburg R, Kock NG, Myrfold HE, Philipson B. Absorption studies in patients six to 10 years after construction of ileostomy reservoirs. Gut 1979;20-499-503.

Pietrzik K, Hages M, Remer T. Methodological aspects in vitamin bioavailability testing. $J$ Micr Nutr Anal 1990;7:207-22.

Prinz-Langenohl R, Brönstrup. Thorand B, Hages M, Pietrzik K. Availability of food folate in humans. J Nutr 1999;129:913-6.

Reisenauer AM, Halsted CH. Human folate requirements. J Nutr 1987;117:600-2.

Sauberlich HE, Kretsch MJ, Skala JH, Johnson $\mathrm{HL}$, Taylor PC. Folate requirement and metabolism in nonpregnant women. Am J Clin Nutr 1987;46:1016-28.

Sauberlich HE. Folate status of the U.S. population groups. In: Bailey L, ed. Folate in health and disease. M. Dekker, New York, NY. 1995:171-94.

Spies TD, Lopez GG, Stone RE, Milanes F, Brandenburg RO, Aramburu T. Further observations on the specifity of the folic acid molecule. Blood 1948;3:121-6.

Steinberg SE, Campbell CL, Hillman RS. Kinetics of the normal folate enterohepatic cycle. J Clin Invest 1979;64:83-8.

Steinberg SE. Mechanisms of folate homeostasis. Am J Physiol 1984;246:G319-G324.

Tamura T, Stokstad ELR. The availability of food folate in man. Br J Haematol 1973;25:513-32.

Wei MM, Bailey LB, Toth JP, Gregory JF III. Bioavailability for humans of deuterium-labeled monoglutamyl and polyglutamyl folates is affected by selected foods. J Nutr 1996;126:3100-8.

Wei MM, Gregory JF III. Organic acids in selected foods inhibit intestinal brush border pteroylpolyglutamate hydrolase in vitro: potential mechanism affecting the bioavailability of dietary polyglutamyl folate. J Agric Food Chem 1998;46:211-9.

Wei MM, Hou ML. Effect of spinach components on folate conjugase activity. The FASEB Journal $2000 ; 14,4$,abstract 166.6 "abstr".

Williams S. Microbiological methods. In: Official Methods of Analysis of the Association of Analytical Chemists, 14 edition 1984:682-73. 


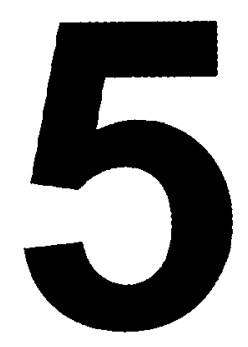

\section{Intake of dietary folate vitamers and risk of colon and rectal cancer Results from the Netherlands Cohort Study}

Erik J.M. Konings, R. Alexandra Goldbohm, Henny A.M. Brants, Wim H.M. Saris, Piet A. van den Brandt 


\section{ABSTRACT}

Background: Several studies have reported inverse associations between folate intake and colorectal cancer risk; very few were prospective studies however, and none examined the association between the intake of individual folate vitamers and colorectal cancer risk.

Methods: The aim of the present study was to investigate the relationship between dietary folate intake and the risk of colon and rectal cancer in a large prospective cohort study in the Netherlands among 120,852 men and women aged 55-69 y. After 7.3 years of follow-up, 760 colon and 411 rectal cancer cases were available for analysis. Data processing and analysis used the case-cohort approach. A new Dutch database was used to estimate intakes of total and individual folates.

Results: Analyses adjusted for age, energy intake, family history of colorectal cancer, alcohol, vitamin $\mathrm{C}$, iron and dietary fiber intake yielded an inverse association between colon cancer risk and total dietary folate intake (RR highest vs. lowest quintile, Men: $0.73 ; 95 \% \mathrm{Cl}, 0.46-1.17, \mathrm{P}$ trend $=0.03$; Women: 0.68 ; $95 \% \mathrm{Cl}, 0.39-1.20, \mathrm{P}$ trend $=0.18)$. An inverse association between rectal cancer and total dietary folate intake was found only among men. (RR highest vs. lowest quintile, Men: $0.66 ; 95 \% \mathrm{Cl}, 0.35-1.21, \mathrm{P}$ trend $=0.03$ ). Analyses for individual folates revealed that intake of 5-methyltetrahydrofolate and 5formyltetrahydrofolate corresponded best with the above associations regarding total folate intake.

Conclusions: Dietary folate intake was inversely related to colon and male rectal cancer risk. 5-Methyltetrahydrofolate and 5-formyltetrahydrofolate account for most of this inverse association.

Key Words: cohort study, colon cancer, rectal cancer, folates 


\section{INTRODUCTION}

International differences, migrant data, and recent rapid changes in incidence rates in Italy, Japan, urban China, and male Polynesians in Hawaii show that colon cancer is particularly sensitive to changes in the environment. Among immigrants and their descendants, incidence rates rapidly reach those of the host country. These differences may be explained, in large part, by dietary and other environmental differences (Potter 1999). Low dietary folate intake, has been found in several epidemiological studies to be associated with an increased risk of colorectal cancer. Freudenheim et al. (1991) first proposed the folate-colorectal cancer hypothesis. They found lower risks of both colon and rectal cancer in association with high dietary folate intakes in a case-control study. Following this study, results of eight case-control studies (Benito et al. 1991, Meyer \& White 1993, Ferraroni et al. 1994, Glynn et al. 1996, Boutron-Ruault et al. 1996, Levi et al. 2000, White et al. 1997, La Vecchia et al. 1997) and two prospective cohort studies (Giovannucci et al. 1995, Giovannucci et al. 1998) investigating the relation between dietary folate intake and colorectal cancer have been reported. In general, a low folate status was associated with an increased risk of colorectal cancer, although the association was not significant in all studies.

Animal studies support the epidemiological concept that dietary folate is protective against colorectal cancer, though the results have not been consistent (Kim 1999).

The relationship between blood levels of folate and colorectal cancer risk is less consistent than that observed between dietary folate intake and colorectal cancer risk (Kim 1999). Results from small folate intervention trials are promising; three large multicenter trials are underway to determine the chemopreventive role of folate supplementation in colorectal carcinogenesis (Kim 1999).

In all epidemiological studies, dietary folate intake was based on the total folate content of foods, usually determined by microbiological assay. Folates comprise an extended family of mono- and polyglutamates (usually 5-7 glutamyl residues) of pteroic acid, all qualitatively exhibiting the biological activity of folic acid. Folate polyglutamates need to be cleaved into folate monoglutamates by pteroylpolyglutamate hydrolase, present in the intestinal brush border, before they can be absorbed in the intestine. Many studies have determined the relative bioavailability of polyglutamates versus corresponding monoglutamates and found it to range from 25 to $100 \%$ (Gregory 1995). Furthermore, several studies have determined the relative bioavailability of the most abundant folate monoglutamates, which may vary between 70 and $129 \%$ relative to folic acid, but there was little agreement between the results (Gregory 1995). Thus, a protective effect of dietary folate might depend on the various folate vitamers consumed. No epidemiological studies have been carried out to investigate the association between individual folate vitamers and colorectal cancer. 
There are a number of candidate mechanisms for folate-associated carcinogenesis. First, folate plays a role in a number of metabolic pathways, such as the biosynthesis of purines and thymidines. Folate deficiency causes massive incorporation of uracil into human DNA as well as chromosome breaks, resulting in the initiation of neoplastic transformation (Blount et al. 1997). These processes returned to normal when individuals receive folic acid supplementation (Blount et al. 1997). Secondly, a mutation in the methylenetetrahydrofolate reductase (MTHFR) gene causes reduced enzyme activity, leading to low plasma folate levels. Although the polymorphism is disadvantageous in homozygous carriers with low folate levels, its presence may reduce colorectal cancer in individuals with an adequate folate supply (Ma et al. 1997, Chen et al 1996). The findings, however, have not been consistent (Slatterly et al. 1999). Thirdly, folate is essential for methylation reactions in the human body. Reduced methylation of DNA, caused by inadequate cellular levels of the methyl donor S-adenosylmethionine, may contribute to loss of normal controls on proto-oncogene expression. Because production of S-adenosylmethionine depends on both methionine and folate, diets deficient in these factors may cause an imbalance in DNA methylation. In humans, hypomethylation of DNA has been observed in colorectal cancers (Feinberg \& Vogelstein 1983). Sufficient methionine intake may also reduce the risk of colorectal cancer (Giovannucci et al. 1993, Giovannucci et al. 1995) and possibly attenuate the beneficial role of folate. Thus, the association between folate and colorectal cancer may be stronger in those with low intake of methionine. A protective effect of folate and methionine against colorectal cancer may be impaired by high alcohol consumption since alcohol acts as a methyl group antagonist (Kune \& Vitetta 1992, Shaw et al. 1989, Herbert \& Colman 1988, Romero et al. 1981, Eichner et al. 1971). In combination with low folate and low methionine intake, heavy drinkers might be at greatest risk of colorectal cancer.

In the present study we investigated the association between the dietary intake of folates and the risk of colorectal cancer in the Netherlands Cohort Study on diet and cancer (NLCS). Separate analyses were performed for colon and rectal cancer, for both men and women as well as for different subsites of the colon. Analyses were done for total dietary folate intake as well as for the intake of individual folate vitamers. The interaction with the intake of methionine and alcohol was taken into account.

\section{METHODS}

\section{Cohort}

The NLCS is a population-based prospective cohort study that was started in the Netherlands in 1986 among 58,279 men and 62,573 women. The study population originated from 204 municipal population registries throughout the country and had 
an age range of 55- to 69 years at baseline. At baseline, all participants completed a self-administered mailed questionnaire on habitual dietary intake, dietary supplement use, lifestyle characteristics, medical history and other potential risk factors for cancer. The case-cohort approach was used for data processing and analysis. Cases were gathered from the entire cohort, whereas the accumulated person years in the cohort were estimated from a subcohort sample consisting of 3500 subjects (1688 men and 1812 women). This subcohort was randomly sampled after the baseline exposure measurement and was followed up biennially for vital status information. A detailed description of the design and characteristics of the cohort study has been reported previously (van den Brandt et al. 1990a).

\section{Follow-up for cancer}

Follow-up for incident cancer was established by record linkage with all regional cancer registries in the Netherlands and the national pathology register (PALGA). The method of record linkage has been reported previously (van den Brandt et al. 1990b). Follow-up was restricted to colon or rectal cancer incidence in the period from September 1986 to December 1992. During these 7.3 years of follow up, 807 pathologically confirmed incident colon cancer and 453 rectal cancer cases were diagnosed. Prevalent cases with cancer other than skin cancer, incident in situ carcinoma and colon and rectal cancer other than carcinoma (sarcoma, lymphoma, unspecified morphology) were excluded as well as subjects with incomplete or inconsistent dietary data were excluded from the analysis. Details of this procedure have been reported elsewhere (Goldbohm et al. 1994). Prevalent cancer cases other than skin cancer were excluded from the subcohort as well. Completeness of follow-up of cancer incidence was more than $96 \%$ (Goldbohm et al. 1994a) and no subcohort members were lost to follow-up.

\section{Dietary intakes}

A 150-item semi-quantitative food frequency questionnaire was used to collect data on the habitual consumption of foods and beverages in the year preceding the start of the study. The questionnaire was validated against a 9-day diet record (Goldbohm et al. 1994b). Intake of B-carotene was based on recent analytical data compiled by Goldbohm et al. (1998). Folate data were derived from a validated liquid chromatography trienzyme method (Konings 1999) used to analyze the 125 most important Dutch foods contributing to folate intake (Konings et al. 2001). The most abundant folate vitamers in foods were evaluated including tetrahydrofolate ( $\mathrm{H}_{4}$ folate), 5-methyltetrahydrofolate $\left(5-\mathrm{CH}_{3}-\mathrm{H}_{4}\right.$ folate), 5-formyltetrahydrofolate (5$\mathrm{CHO}_{4} \mathrm{H}_{4}$ folate), 10-formylfolic acid (10-HCO-folic acid), 10-formyldihydrofolate (10$\mathrm{HCO}-\mathrm{H}_{2}$ folate) and folic acid, and the grouped folates total monoglutamates $\left(\mathrm{H}_{4}\right.$ folate, 5- $\mathrm{CH}_{3}-\mathrm{H}_{4}$ folate 5-CHO-H $\mathrm{H}_{4}$ folate, 10-HCO-folic acid, $10-\mathrm{HCO}-\mathrm{H}_{2}$ folate and folic acid) and total polyglutamates $\left(\mathrm{H}_{4}\right.$ folate, $5-\mathrm{CH}_{3}-\mathrm{H}_{4}$ folate $5-\mathrm{CHO}-\mathrm{H}_{4}$ folate, $10-$ 
$\mathrm{HCO}-$ folic acid, $10-\mathrm{HCO}-\mathrm{H}_{2}$ folate and folic acid). Not all food products were analyzed for individual vitamers; folate intake from foods analyzed for individual vitamers covered $90 \%$ of total folate intake. The mean daily intakes of all other relevant nutrients were calculated using the computerized Dutch Food Composition Table (NEVO tabel 1986).

\section{Population for analysis}

Ultimately, 760 colon cancer cases (400 men, 360 women), 411 rectal cancer cases (259 men and 152 women) and 3123 subcohort members (1525 men and 1598 women) were available for analysis. Of all malignant tumors in the colon, 378 (187 men, 191 women) originated in the proximal part (ICD-O topography (International Classification of diseases for Oncology 1976) codes 153.0, 153.4-6), whereas 348 (195 men, 153 women) originated in the distal part (ICD-O codes 153.2-3 and 153.7), 14 were unspecified (ICD-O code 153.9) and 10 had overlapping boundaries (ICD-O code 153.8). Malignant tumors of the rectosigmoid and/or rectum (ICD-O codes 154.0 and 154.1) were regarded as rectal cancer cases.

\section{Statistical analysis}

Total folate intake was calculated and categorized into quintiles according to the distribution in the subcohort. The Stata statistical package (release 6.0) (Statacorp 1999) was used to estimate incidence rate ratios (RR) and corresponding $95 \%$ confidence intervals $(\mathrm{Cl})$ for colon or rectal cancer, using exponentially distributed failure time regression models (Volovics \& van den Brandt 1997).

Age-adjusted RRs for colon and rectal cancer and their $95 \% \mathrm{Cls}$ were calculated. Tests for trend were based on two-sided likelihood ratio tests. Total energy, alcohol intake, smoking, physical activity, body mass index, meat consumption and family history of colorectal cancer were evaluated as potential confounders. In our study, family history of colorectal cancer (yes/no) and alcohol intake were related to colorectal cancer (Voorrips et al. 2000). Adjustment was made for these factors in a multivariate model. Since energy consumption (kcal/d) is frequently regarded as a potential confounder, this was included in the multivariate model. Additionally, models were used which adjusted for vitamin $\mathrm{C}$, iron and dietary fiber, as these nutrient intakes were highly correlated with folate intake.

The independent contribution of each folate vitamer was assessed through analyses in which total folate intake was included in the model simultaneously.

To date, it is not allowed in the Netherlands to fortify foods with folic acid. For the time being, an intake of $200 \mathrm{~g}$ vegetables and 2 pieces of fruit daily is recommended to enhance intake of folate and other nutrients. This is approximately double the amount of fruit and vegetables found to be consumed in 
the Dutch National Food Consumption Survey (DNFCS) carried out in 1992. The current population-based fruit and vegetable intake accounts for approximately 50 $\mu \mathrm{g}$ folate (Konings et al. 2001). To calculate a possible risk reduction resulting from an additional folate intake of $50 \mu \mathrm{g} / \mathrm{d}$, corresponding to the current recommendations of the Dutch Health Council, the association between folate intake as a continuous variable and colon and rectal cancer was calculated per increment of $50 \mu \mathrm{g} / \mathrm{d}$.

Additional analyses were performed after exclusion of cancer cases diagnosed in the first year of follow-up, because preclinical symptoms might have influenced the dietary habits. Separate analyses were conducted for subsite-specific colon carcinoma. To examine whether possible beneficial effects of folate might be limited to subjects with low methionine intake, associations between dietary folate intake and colon and rectal cancer were determined for low versus high methionine intake. The joint effects of low folate intake in combination with low methionine intake and high alcohol consumption were considered versus intermediate intakes and high folate intake along with high methionine intake and low alcohol intake. Quintiles 1 and 2 were defined as low intake, while intermediate intake was defined as quintile 3 and high intake as quintile 4 and 5. Low and high alcohol intake were defined as $\leq 4 \mathrm{~g} / \mathrm{d}$ and $\geq 15 \mathrm{~g} / \mathrm{d}$ respectively, with $5-14 \mathrm{~g} / \mathrm{d}$ as intermediate intake.

\section{RESULTS}

Table 1 presents the mean daily intake of total folate and individual folate vitamers, as well as several other relevant characteristics. The mean age of the subcohort members was $61.4 \mathrm{y}$ for both men and women. Cases were generally older (by approximately $1.2 \mathrm{y}$ ). Among subcohort members, approximately $5 \%$ had a family history of colorectal cancer. This percentage was approximately $10 \%$ among cases. Dietary folate intake among subcohort members and cases was comparable. Mean ( \pm SD) dietary folate was $224 \pm 73 \mu \mathrm{g} / \mathrm{d}$ for men in the subcohort versus $200 \pm 65 \mu \mathrm{g} / \mathrm{d}$ for women. Comparable intakes among subcohort members and cases were also found for methionine, energy, iron, vitamin $C$ and dietary fiber. The percentages of alcohol abstainers among the subcohort members were $15.3 \%$ and $32.1 \%$ for men and women respectively. These percentages were comparable for cases, with the exception of male rectal cancer cases, where the percentage of alcohol abstainers was considerably lower $(11.3 \%)$. Pearson correlation coefficients between folate intake and iron, vitamin $\mathrm{C}$ and dietary fiber intake were $0.67,0.53$ and 0.60 respectively. 


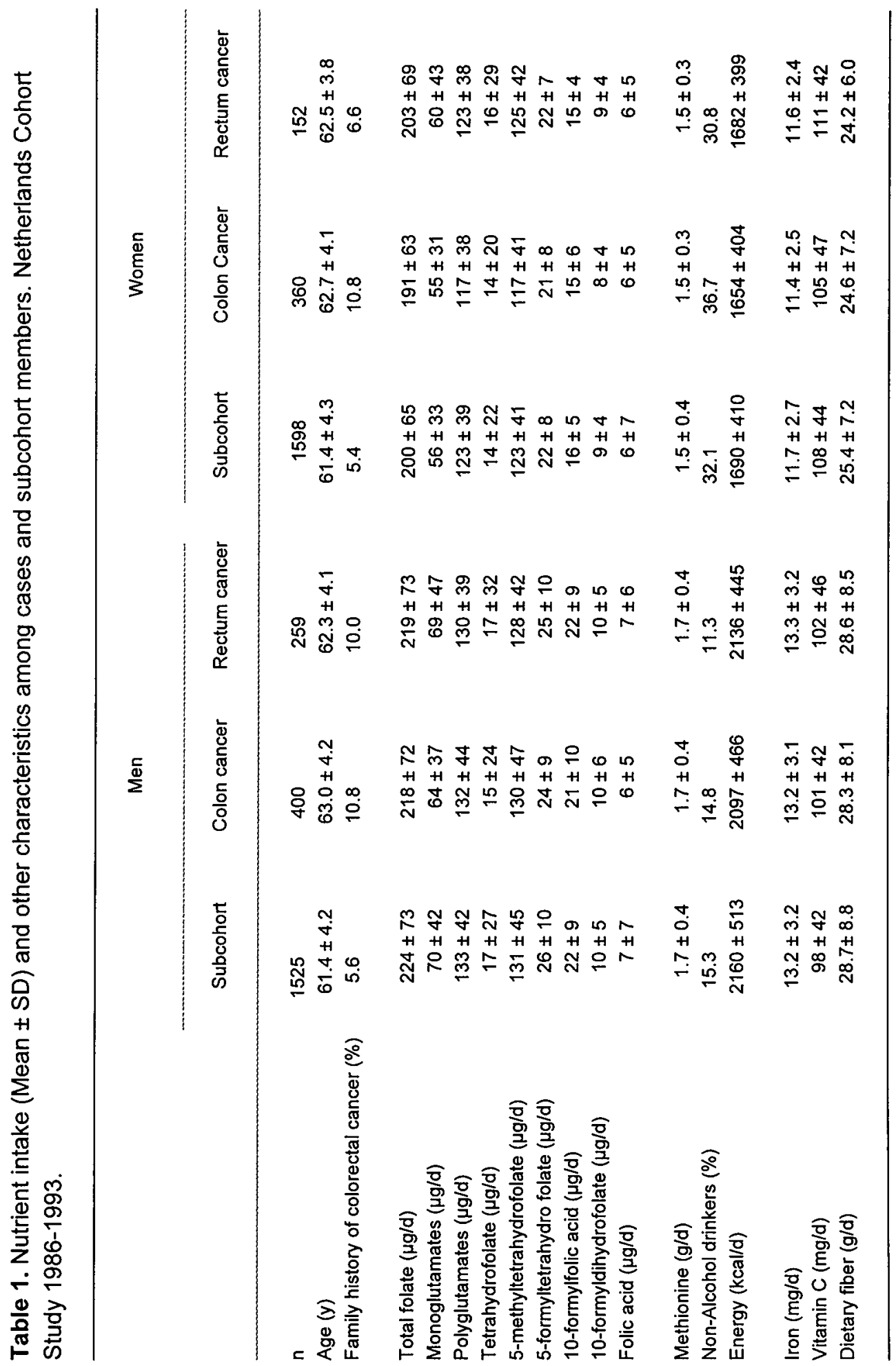


The association between dietary folate intake and colon cancer is presented in table 2.

Table 2. Incidence rate ratio (RR) of colon cancer according to folate intake levels in multivariate analyses according to years of follow-up; Netherlands Cohort Study, 1986-1993.

\begin{tabular}{|c|c|c|c|c|c|c|}
\hline $\begin{array}{l}\text { Quintiles of folate intake } \\
\text { Boundaries in ( } \mu \mathrm{g} / \text { day) }\end{array}$ & $\begin{array}{c}\text { Cases in } \\
\text { cohort }\end{array}$ & $\begin{array}{l}\text { Person years } \\
\text { In subcohort }\end{array}$ & $\operatorname{RR}(95 \% \mathrm{Cl})^{*}$ & $\operatorname{RR}(95 \% \mathrm{Cl})^{*}$ & $\operatorname{RR}(95 \% \mathrm{Cl})^{\dagger}$ & $\operatorname{RR}(95 \% \mathrm{Cl})^{\dagger}$ \\
\hline
\end{tabular}

\begin{tabular}{|c|c|c|c|c|c|c|}
\hline \multicolumn{7}{|c|}{ Men, colon cancer } \\
\hline $1(<168)$ & 98 & 2042 & 1.00 (reference) & 1.00 (reference) & 1.00 (reference) & 1.00 (reference) \\
\hline $2(168-198)$ & 87 & 2122 & $0.88(0.63-1.24)$ & $0.92(0.65-1.31)$ & $0.84(0.59-1.21)$ & $1.01(0.69-1.48)$ \\
\hline $3(198-226)$ & 66 & 2148 & $0.66(0.46-0.95)$ & $0.68(0.46-0.99)$ & $0.59(0.40-0.88)$ & $0.72(0.47-1.10)$ \\
\hline $4(226-266)$ & 62 & 2104 & $0.66(0.46-0.94)$ & $0.70(0.47-1.03)$ & $0.58(0.38-0.90)$ & $0.71(0.45-1.12)$ \\
\hline $5(>266)$ & 87 & 2092 & $0.94(0.67-1.32)$ & $1.01(0.68-1.50)$ & $0.73(0.46-1.17)$ & $0.93(0.57-1.52)$ \\
\hline$p$-value for linear trend & & & 0.22 & 0.50 & 0.03 & 0.29 \\
\hline \multicolumn{7}{|c|}{ Women, colon cancer } \\
\hline $1(<150)$ & 91 & 2257 & 1.00 (reference) & 1.00 (reference) & 1.00 (reference) & 1.00 (reference) \\
\hline $2(150-176)$ & 75 & 2276 & $0.86(0.61-1.21)$ & $0.85(0.59-1.22)$ & $0.84(0.57-1.23)$ & $0.91(0.61-1.35)$ \\
\hline $3(176-203)$ & 70 & 2262 & $0.80(0.56-1.13)$ & $0.81(0.55-1.19)$ & $0.79(0.52-1.21)$ & $0.84(0.54-1.30)$ \\
\hline $4(203-243)$ & 69 & 2262 & $0.80(0.56-1.14)$ & $0.84(0.56-1.25)$ & $0.81(0.50-1.33)$ & $0.87(0.52-1.45)$ \\
\hline $5(>243)$ & 55 & 2277 & $0.65(0.45-0.95)$ & $0.71(0.46-1.08)$ & $0.68(0.39-1.20)$ & $0.66(0.36-1.21)$ \\
\hline$p$-value for linear trend & & & 0.01 & 0.10 & 0.18 & 0.18 \\
\hline
\end{tabular}

- adjusted for age (years),

adjusted for age, alcohol intake, energy intake, family history of colorectal cancer

tadjusted for age, alcohol intake, energy intake, family history of colorectal cancer, iron intake, vitamin c intake and dietary fiber intake.

Generally, higher total dietary folate intake was related to a lower risk of colon cancer, although among men the RR increased again towards unity in the highest quintile of folate intake compared to the fourth quintile. Age-adjusted and multivariate analyses (including age, alcohol intake, energy intake and family history of colorectal cancer) yielded comparable results. When iron intake, vitamin $C$ intake and dietary fiber intake were also included in the multivariate analyses, RRs were considerably more inverse, especially for men. A multivariate analysis including age, alcohol intake, energy intake, family history of colorectal cancer, iron intake, vitamin $C$ intake and dietary fiber intake revealed a significant inverse association between dietary folate intake and colon cancer risk for men (RR hi vs. 
lo $=0.73 ; 95 \% \mathrm{Cl}, 0.46-1.17, \mathrm{P}$ trend $=0.03$ ). Age-adjusted analysis for women revealed a significant inverse association between dietary folate intake and colon cancer. Adjustment with other covariates yielded similar results, although the $P$ for trend increased. A multivariate analysis including age, alcohol intake, energy intake, family history of colorectal cancer, iron intake, vitamin $C$ intake and dietary fiber intake resulted in a RR for the highest versus lowest quintile of $0.68(95 \% \mathrm{Cl}$, $0.39-1.20, P$ trend $=0.18$ ). In the continuous analysis, the RR decreased by approximately $10 \%$ in both men and women for each $50 \mu \mathrm{g}$ increment of dietary folate intake per day. Exclusion of cases diagnosed in the first year of follow-up resulted in somewhat higher RRs.

The association between dietary folate intake and rectal cancer is presented in table 3.

Table 3. Incidence rate ratio (RR) of rectal cancer according to folate intake levels in multivariate analyses according to years of follow-up; Netherlands Cohort Study, 1986-1993.

\begin{tabular}{|c|c|c|c|c|c|c|}
\hline $\begin{array}{l}\text { Quintiles of folate intake } \\
\text { Boundaries in ( } \mu g / \text { day) }\end{array}$ & $\begin{array}{c}\text { Cases in } \\
\text { cohort }\end{array}$ & $\begin{array}{l}\text { Person years } \\
\text { In subcohort }\end{array}$ & $\operatorname{RR}(95 \% \mathrm{Cl})^{\prime \prime}$ & $\operatorname{RR}(95 \% \mathrm{Cl})^{*}$ & $\operatorname{RR}(95 \% \mathrm{Cl})^{\dagger}$ & $\mathrm{RR}(95 \% \mathrm{CI})^{t}$ \\
\hline
\end{tabular}

\begin{tabular}{|c|c|c|c|c|c|c|}
\hline \multicolumn{7}{|c|}{ Men, rectal cancer } \\
\hline $1(<168)$ & 54 & 2048 & 1.00 (reference) & 1.00 (reference) & 1.00 (reference) & 1.00 (reference) \\
\hline $2(168-198)$ & 64 & 2124 & $1.17(0.78-1.74)$ & $1.19(0.78-1.79)$ & $1.07(0.70-1.63)$ & $1.06(0.68-1.66)$ \\
\hline $3(198-226)$ & 46 & 2142 & $0.83(0.54-1.27)$ & $0.80(0.51-1.26)$ & $0.67(0.42-1.09)$ & $0.66(0.40-1.09)$ \\
\hline $4(226-266)$ & 46 & 2108 & $0.86(0.56-1.32)$ & $0.86(0.54-1.36)$ & $0.68(0.41-1.13)$ & $0.72(0.42-1.21)$ \\
\hline $5(>266)$ & 49 & 2103 & $0.93(0.61-1.41)$ & $0.94(0.56-1.58)$ & $0.66(0.35-1.21)$ & $0.69(0.36-1.31)$ \\
\hline p-value for linear trend & & & 0.28 & 0.33 & 0.03 & 0.06 \\
\hline \multicolumn{7}{|c|}{ Women, rectal cancer } \\
\hline $1(<150)$ & 29 & 2261 & 1.00 (reference) & 1.00 (reference) & 1.00 (reference) & 1.00 (reference) \\
\hline $2(150-176)$ & 30 & 2276 & $1.08(0.63-1.84)$ & $1.17(0.66-2.09)$ & $1.18(0.65-2.15)$ & $1.37(0.73-2.60)$ \\
\hline $3(176-203)$ & 30 & 2270 & $1.06(0.62-1.82)$ & $1.18(0.65-2.16)$ & $1.22(0.65-2.28)$ & $1.35(0.69-2.65)$ \\
\hline $4(203-243)$ & 32 & 2267 & $1.15(0.68-1.96)$ & $1.26(0.68-2.36)$ & $1.28(0.63-2.59)$ & $1.20(0.56-2.58)$ \\
\hline $5(>243)$ & 31 & 2280 & $1.14(0.67-1.96)$ & $1.28(0.67-2.48)$ & $1.26(0.58-2.76)$ & $1.25(0.54-2.92)$ \\
\hline p-value for linear trend & & & 0.56 & 0.40 & 0.55 & 0.81 \\
\hline
\end{tabular}

- adjusted for age (years).

adjusted for age, alcohol intake, energy intake, family history of colorectal cancer

${ }^{\dagger}$ adjusted for age, alcohol intake, energy intake, family history of colorectal cancer, iron intake, vitamin c intake and dietary fiber intake. 
Dietary folate intake was not related to the risk of rectal cancer in age-adjusted and multivariate analyses including age, alcohol intake, energy intake and family history of colorectal cancer. After additional adjustment for iron intake, vitamin C intake and dietary fiber intake, however, the RRs showed an inverse association between dietary folate intake and rectal cancer risk among men (RR hi vs. lo = $0.66 ; 95 \% \mathrm{Cl}, 0.35-1.21, \mathrm{P}$ trend $=0.03$ ). Among women there was no inverse association between dietary folate intake and rectal cancer. In the multivariate analysis the RR for the highest versus lowest quintile was $1.26(95 \% \mathrm{Cl}, 0.58-2.76$, $P$ trend $=0.55$ ). RRs were slightly higher when cases diagnosed in the first year of follow-up were excluded.

Table 4 shows the results of a multivariate analysis for individual folate vitamers. Beneficial effects of folate intake might be stronger for folate monoglutamates than for folate polyglutamates, since the relative bioavailability of polyglutamates versus their corresponding monoglutamates might be as low as $25 \%$. The RRs for the highest versus lowest quintile of polyglutamates were on average lower than RRs for the highest versus lowest quintile of monoglutamates for colon and rectal cancer (RRs for rectal cancer among women were not taken into account because of the absence of an association between total folate intake and rectal cancer risk). Beneficial effects of folate intake might also vary between individual vitamers. Results of a multivariate analysis for individual folate vitamers showed that the effect of total folate intake on the risk of colon and rectal cancer is almost similar to that of 5-methyltetrahydrofolate. Although the intake of 5formyltetrahydrofolate was a fifth of that of 5-methyltetrahydrofolate, this vitamer showed the strongest inverse association with colon and rectal cancer. Among men, the inverse association between 5 -formyltetrahydrofolate and colon cancer was even stronger (RR hi vs. lo $=0.56, P$ trend $=0.03$ ) than that between 5methyltetrahydrofolate and colon cancer (RR hi vs. $10=1.30, P$ trend $=0.95$ ). Weaker associations were found for the other vitamers. 
Table 4. Incidence rate ratio RR of colon and rectal cancer according to intake of different folate vitamers; Netherlands Cohort Study, 1986-1993.

\begin{tabular}{|c|c|c|c|c|c|}
\hline \multicolumn{3}{|c|}{ Men } & \multicolumn{3}{|c|}{ Women } \\
\hline & colon cancer & rectal cancer & & colon cancer & rectal cancer \\
\hline $\begin{array}{l}\text { Quintiles of folate } \\
\text { intake ( } \mu g / \text { day) }\end{array}$ & $\operatorname{RR}(95 \% \mathrm{CI})^{\dagger}$ & $\operatorname{RR}(95 \% \mathrm{Cl})^{\dagger}$ & $\begin{array}{l}\text { Quintiles of folate intake } \\
\qquad(\mu g / \text { day })\end{array}$ & $\operatorname{RR}(95 \% \mathrm{Cl})^{\dagger}$ & $\operatorname{RR}(95 \% \mathrm{Cl})^{\dagger}$ \\
\hline
\end{tabular}

$\begin{array}{lc}1(<44) & 1.00 \text { (reference) } \\ 2(44-53) & 0.86(0.60-1.23) \\ 3(53-66) & 0.90(0.62-1.31) \\ 4(66-86) & 0.70(0.46-1.08) \\ 5(>86) & 0.80(0.47-1.38) \\ \text { p-value for trend } & 0.18\end{array}$

p-value for trend

$1(<100)$

$2(100-118)$

$3(118-136)$

$4(136-161)$

5 (>161)

$\mathrm{p}$-value for trend

$\begin{array}{lc}1(<96) & 1.00 \text { (reference) } \\ 2(96-116) & 0.98(0.67-1.42) \\ 3(116-134) & 0.76(0.48-1.19) \\ 4(134-160) & 0.85(0.51-1.42) \\ 5(>160) & 1.32(0.67-2.62) \\ p \text {-value for trend } & 0.88\end{array}$

$1(<18)$

2 (18-23)

3 (23-27)

$4(27-33)$

5 (>33)

$\mathrm{p}$-value for trend

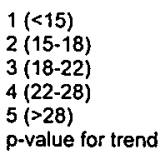

$1(<3)$

$2(3-7)$

$3(7-12)$

$4(12-23)$

$5(>23)$

$\mathrm{p}$-value for trend

$\begin{array}{lc}1(<6) & 1.00 \text { (reference) } \\ 2(6-8) & 0.91(0.64-1.29) \\ 3(8-11) & 0.80(0.55-1.16) \\ 4(11-15) & 0.80(0.55-1.16) \\ 5(>15) & 0.96(0.66-1.42) \\ \text { p-value for trend } & 0.50\end{array}$

$\begin{array}{lc}1(<3) & 1.00 \text { (reference) } \\ 2(3-5) & 0.74(0.52-1.05) \\ 3(5-7) & 0.78(0.54-1.12) \\ 4(7-9) & 1.07(0.75-1.54) \\ 5(>9) & 0.76(0.52-1.11) \\ \text { p-value for trend } & 0.57\end{array}$

1.00 (reference)

$1.10(0.75-1.60)$

$0.95(0.62-1.46)$

$0.90(0.54-1.49)$

$1.30(0.67-2.52)$

0.95

1.00 (reference)
$0.77(0.54-1.10)$
$0.74(0.50-1.09)$
$0.72(0.48-1.07)$
$0.56(0.33-0.94)$
0.03

\begin{abstract}
1.00 (reference)
$0.75(0.52-1.08)$

0.66 (0.44-0.98)

$0.74(0.49-1.13)$

$0.85(0.52-1.38)$

0.43
\end{abstract}

1.00 (reference)
$1.14(0.81-1.62)$
$0.82(0.56-1.19)$
$0.87(0.59-1.28)$
$0.97(0.62-1.51)$
0.30 monoglutamates

$\begin{array}{cc}1.00 \text { (reference) } & 1(<36) \\ 1.19(0.76-1.88) & 2(36-43) \\ 1.42(0.87-2.31) & 3(43-52) \\ 1.55(0.89-2.69) & 4(52-68) \\ 1.56(0.77-3.17) & 5(>68) \\ 0.07 & \end{array}$

polyglutamates

\begin{abstract}
1.00 (reference)
$1.09(0.70-1.69)$

$1.11(0.68-1.80)$

$0.78(0.44-1.40)$

$0.88(0.40-1.94)$

$$
0.42
$$
\end{abstract}

$1(<91)$

$2(91-110)$

$3(110-126)$

$4(126-151)$

$5(>151)$

5-methyltetrahydrofolate 1.00 (reference)
$1.14(0.77-1.70)$
$1.39(0.92-2.11)$
$1.35(0.84-2.16)$
$1.86(1.03-3.36)$
0.03
1.00 (reference)

$0.82(0.44-1.50)$

$1.07(0.58-1.96)$

$1.02(0.55-1.90)$

$0.67(0.30-1.49)$

0.70 $\begin{array}{cc}1.00 \text { (reference) } & 1.00 \text { (reference) } \\ 1.11(0.76-1.63) & 1.36(0.75-2.47) \\ 0.83(0.54-1.27) & 1.10(0.57-2.12) \\ 0.83(0.50-1.38) & 1.46(0.70-3.05) \\ 0.72(0.37-1.40) & 1.47(0.60-3.62) \\ 0.17 & 0.42\end{array}$
1.00 (reference)
$1.16(0.74-1.82)$
$0.78(0.46-1.33)$
$0.89(0.49-1.60)$
$0.75(0.31-1.81)$ 0.28

$1(<89)$
$2(89-108)$
$3(108-125)$
$4(125-152)$
$5(>152)$

5-formyltetrahydrofolate

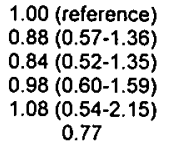

$1(<16)$

2 (16-20)

$3(20-23)$

$4(23-28)$

$5(>28)$

0.77

10-formylfolic acid

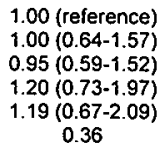

1 (<11)

$2(11-14)$

3 (14-16)

4 (16-19)

0.36

$5(>19)$

tetrahydrofolate

1.00 (reference)

$0.93(0.60-1.44)$

$1.09(0.70-1.69)$

$1.34(0.86-2.09)$

$1.19(0.69-2.06)$

0.14

$1(<3)$

$2(3-6)$

$3(6-10)$

$4(10-19)$

$5(>19)$

10-formyldihydrofolate

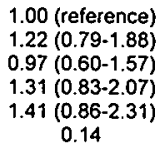

$1(<5)$

2 (5-7)

$3(7-9)$

$4(9-12)$

$5(>12)$
1.00 (reference) $0.82(0.55-1.23)$ $0.83(0.53-1.29)$

$0.83(0.48-1.43)$

$0.68(0.32-1.48)$ 0.40

1.00 (reference)

$1.00(0.69-1.44)$

$0.83(0.55-1.26)$

$0.86(0.56-1.32)$

$0.90(0.53-1.52)$

0.44

1.00 (reference)

$0.78(0.53-1.14)$

$0.93(0.61-1.40)$

$0.76(0.49-1.19)$

$0.70(0.39-1.25)$

0.20

1.00 (reference)

$1.02(0.70-1.50)$

$1.22(0.84-1.78)$

1.35 (0.91-2.01)

$1.48(0.94-2.32)$

0.02

1.00 (reference)

$1.11(0.75-1.63)$

$1.12(0.76-1.64)$

$1.21(0.82-1.78)$

$1.02(0.67-1.55)$

0.72

1.00 (reference)

$1.16(0.64-2.09)$

$0.85(0.43-1.66)$

$1.29(0.62-2.72)$

$1.14(0.41-3.15)$

0.72

$0.77(0.40-1.49)$

$1.46(0.80-2.66)$

$1.01(0.45-2.26)$

0.91

1.00 (reference)

$1.41(0.81-2.46)$

$1.17(0.63-2.17)$

$1.94(1.04-3.61)$

$0.94(0.41-2.12)$

0.48

1.00 (reference)

$1.31(0.76-2.25)$

$1.09(0.63-1.90)$

$0.97(0.54-1.73)$

$0.82(0.42-1.59)$

0.39

1.00 (reference)

$1.14(0.64-2.03)$

$1.05(0.58-1.89)$

$1.12(0.63-2.00)$

0.80
1.00 (reference)

$1.53(0.89-2.61)$

folic acid

1.00 (reference)
$0.91(0.60-1.38)$
$0.94(0.61-1.44)$
$1.24(0.81-1.91)$
$0.89(0.57-1.39)$
0.83

$1(<3)$
$2(3-4)$
$3(4-5)$
$4(5-7)$
$5(>7)$

1.00 (reference)

$0.96(0.66 \cdot 1.39)$

$0.91(0.62-1.34)$

$0.87(0.59-1.29)$

$0.80(0.54-1.20)$

0.20

$1.10(0.61-1.99)$

\author{
1.00 (reference) \\ $0.78(0.44-1.39)$ \\ $0.80(0.44-1.44)$ \\ $0.85(0.47-1.57)$ \\ $1.21(0.68-2.16)$ \\ 0.42
}

\footnotetext{
' adjusted for age, atcohol intake, energy intake, family history of colorectal cancer, iron, vitamin c, dietary fiber and total folate intake.
} 
Colon cancer cases were classified according to specific colon subsites. There appeared to be no differences in the association between folate intake and cancer at specific subsites. Inverse associations were found for total dietary folate intake and both distal and proximal colon cancer in men and women (Table 5). For men, the RRs for the highest versus the lowest quintile were $0.75(95 \% \mathrm{Cl}, 0.39-1.44)$ and $0.74(95 \% \mathrm{Cl}, 0.40-1.35)$ for proximal and distal colon cancer respectively. Among women, the RR values for highest versus lowest quintile were 0.72 (95\% $\mathrm{Cl}, 0.33-1.54)$ and $0.69(95 \% \mathrm{Cl}, 0.31-1.52)$ for proximal and distal colon cancer respectively.

Table 5. Incidence rate ratios (RR) of colon cancer according to quintiles of folate intake and subsite; Netherlands Cohort Study, 1986-1993.

\begin{tabular}{|c|c|c|c|c|c|}
\hline \multicolumn{3}{|c|}{ Men } & \multicolumn{3}{|c|}{ Women } \\
\hline & $\begin{array}{l}\text { proximal }{ }^{1} \text { colon } \\
\text { cancer } \\
\text { (186 cases) }\end{array}$ & $\begin{array}{l}\text { distal }^{2} \text { colon } \\
\text { cancer } \\
\text { (194 cases) }\end{array}$ & & $\begin{array}{l}\text { proximal' colon } \\
\text { cancer } \\
\text { (185 cases) }\end{array}$ & $\begin{array}{l}\text { distal }\left.\right|^{2} \text { colon } \\
\text { cancer } \\
\text { (152 cases) }\end{array}$ \\
\hline $\begin{array}{l}\text { Quintiles of folate } \\
\text { intake ( } \mu \mathrm{g} / \text { day) }\end{array}$ & $\mathrm{RR}(95 \% \mathrm{Cl})^{\dagger}$ & $\operatorname{RR}(95 \% \mathrm{CI})^{\dagger}$ & $\begin{array}{l}\text { Quintiles of folate } \\
\text { intake ( } \mu \text { g/day) }\end{array}$ & $\mathrm{RR}(95 \% \mathrm{Cl})^{t}$ & $\operatorname{RR}(95 \% \mathrm{CI})^{\dagger}$ \\
\hline $1(<168)$ & 1.00 (reference) & 1.00 (reterence) & $1(<150)$ & 1.00 (reference) & 1.00 (reference) \\
\hline $2(168-198)$ & $0.87(0.53-1.42)$ & $0.84(0.53-1.33)$ & $2(150-176)$ & $0.84(0.51-1.40)$ & $0.87(0.51-1.48)$ \\
\hline $3(198-226)$ & $0.66(0.38-1.15)$ & $0.52(0.31-0.88)$ & $3(176-203)$ & $0.81(0.47-1.42)$ & $0.83(0.46-1.51)$ \\
\hline $4(226-266)$ & $0.67(0.38-1.21)$ & $0.50(0.28-0.89)$ & $4(203-243)$ & $1.03(0.55-1.95)$ & $0.68(0.33-1.41)$ \\
\hline $5(>266)$ & $0.75(0.39-1.44)$ & $0.74(0.40-1.35)$ & $5(>243)$ & $0.72(0.33-1.54)$ & $0.69(0.31-1.52)$ \\
\hline p-value for trend & 0.24 & 0.08 & & 0.66 & 0.26 \\
\hline
\end{tabular}

tadjusted for age, alcohol intake, energy intake, family history of colorectal cancer, ison intake, vitamin c intake and dietary fiber intake.

'ICD codes: $153.0,153.1,153.4,153.5,153.6$.

${ }^{2}$ ICD codes: 153.2 . 153.3, 153.7 .

Results on the interaction between folate and methionine are shown in table 6 . The inverse association between folate and colon and rectal cancer in the lower half of methionine intake appeared to be limited to men ( $P$-values for statistical interaction were 0.30 and 0.04 for colon cancer and men and women respectively and 0.89 and 0.35 for rectal cancer for men and women respectively). 
Table 6. Incidence rate ratios (RR) of colon and rectal cancer according to quintiles of folate intake and level of methionine intake; Netherlands Cohort Study, 19861993.

\begin{tabular}{|c|c|c|c|c|c|}
\hline \multicolumn{3}{|c|}{ Men } & \multicolumn{3}{|c|}{ Women } \\
\hline & $\begin{array}{l}\text { low methionine } \\
\text { intake } \leq 1.58 \mathrm{~g} / \mathrm{d} \\
(176 \text { cases) }\end{array}$ & $\begin{array}{l}\text { high methionine } \\
\text { intake } \geq 1.78 \mathrm{~g} / \mathrm{d} \\
\text { ( } 142 \text { cases) }\end{array}$ & & $\begin{array}{c}\text { low methionine } \\
\text { intake } \leq 1.38 \mathrm{~g} / \mathrm{d} \\
\text { (146 cases) }\end{array}$ & $\begin{array}{l}\text { high methionine } \\
\text { intake } \geq 1.56 \mathrm{~g} / \mathrm{d} \\
\text { (134 cases) }\end{array}$ \\
\hline $\begin{array}{l}\text { Quintiles of folate } \\
\text { intake ( } \mu \mathrm{g} / \text { day) }\end{array}$ & $\operatorname{RR}(95 \% \mathrm{Cl})^{\dagger}$ & $\operatorname{RR}(95 \% \mathrm{Cl})^{\dagger}$ & $\begin{array}{l}\text { Quintiles of folate } \\
\text { intake ( } \mu \mathrm{g} / \text { day) }\end{array}$ & $\operatorname{RR}(95 \% \mathrm{Cl})^{t}$ & $\operatorname{RR}(95 \% \mathrm{Cl})^{\dagger}$ \\
\hline \multicolumn{6}{|c|}{ Colon } \\
\hline $1(<168)$ & 1.00 (reference) & $0.57(0.18-1.78)$ & $1(<150)$ & 1.00 (reference) & $1.79(0.84-3.81)$ \\
\hline $2(168-198)$ & $0.91(0.58-1.43)$ & $0.61(0.33-1.14)$ & $2(150-176)$ & $0.73(0.44-1.23)$ & $1.21(0.62-2.34)$ \\
\hline $3(198-226)$ & $0.49(0.28-0.84)$ & $0.66(0.37-1.16)$ & $3(176-203)$ & $0.95(0.54-1.66)$ & $0.77(0.41-1.44)$ \\
\hline $4(226-266)$ & $0.43(0.22-0.87)$ & $0.53(0.31-0.91)$ & $4(203-243)$ & $1.50(0.77-2.94)$ & $0.87(0.47-1.61)$ \\
\hline $5(>266)$ & $0.46(0.19-1.10)$ & $0.75(0.42-1.35)$ & $5(>243)$ & $0.38(0.13-1.09)$ & $0.84(0.41-1.72)$ \\
\hline$p$-value for trend" & 0.0004 & 0.34 & & 0.76 & 0.09 \\
\hline \multicolumn{6}{|c|}{ Rectum } \\
\hline & (109 cases) & (91 cases) & & (51 cases) & (60 cases) \\
\hline $1(<168)$ & 1.00 (reference) & $0.52(0.11-2.40)$ & $1(<150)$ & 1.00 (reference) & $3.17(1.16-8.69)$ \\
\hline $2(168-198)$ & $1.26(0.73-2.17)$ & $1.15(0.58-2.26)$ & $2(150-176)$ & $1.36(0.61-3.03)$ & $1.41(0.48-4.18)$ \\
\hline $3(198-226)$ & $0.82(0.44-1.54)$ & $0.64(0.32-1.30)$ & $3(176-203)$ & $1.34(0.55-3.25)$ & $1.67(0.65-4.27)$ \\
\hline $4(226-266)$ & $0.50(0.21-1.21)$ & $0.59(0.30-1.17)$ & $4(203-243)$ & $2.20(0.81-5.98)$ & $1.77(0.70-4.52)$ \\
\hline $5(>266)$ & $0.59(0.21-1.62)$ & $0.62(0.27-1.43)$ & $5(>243)$ & $1.08(0.28-4.23)$ & $2.01(0.71-5.70)$ \\
\hline $\mathrm{p}$-value for trend* & 0.02 & 0.32 & & 0.63 & 0.97 \\
\hline
\end{tabular}

tadjusted for age, alcohol intake, energy intake, family history of colorectal cancer, iron intake. vitamin c intake and dietary fiber intake. test for trend based on separate models stratified by methionine level.

Because alcohol acts as a methyl group antagonist, low intakes of folate and methionine among substantial alcohol users might be stronger risk factors for colon and rectal cancer. To examine this hypothesis, subgroups were formed of those with low intake levels of folate and methionine in combination with high intake levels of alcohol and vice versa. Results are shown in table 7. For men, the RR estimates for low folate - low methionine - high alcohol intakes versus high folate high methionine - low alcohol intakes were $1.26(95 \% \mathrm{Cl}, 0.59-2.70)$ for colon cancer and 2.69 (95\% Cl: 0.99-7.29) for rectal cancer. For women, the RR values for high alcohol - low methionine - low folate intakes versus low alcohol - high methionine - high folate intakes were $1.01(95 \% \mathrm{Cl}, 0.40-2.54)$ for colon cancer and $0.45(95 \% \mathrm{Cl}, 0.14-1.50)$ for rectal cancer. 
Table 7. Incidence rate ratios (RR) of colon and rectal cancer according to a combination of folate intake, methionine intake and alcohol intake; Netherlands Cohort Study, 1986-1993*.

\begin{tabular}{|c|c|c|c|c|}
\hline & \multicolumn{2}{|c|}{ Colon cancer } & \multicolumn{2}{|c|}{ Rectal cancer } \\
\hline & $\begin{array}{c}\text { Men } \\
\text { (85 cases) }\end{array}$ & $\begin{array}{l}\text { Women } \\
\text { (67 cases) }\end{array}$ & $\begin{array}{c}\text { Men } \\
\text { (47 cases) }\end{array}$ & $\begin{array}{l}\text { Women } \\
\text { (32 cases) }\end{array}$ \\
\hline & $\operatorname{RR}(95 \% \mathrm{Cl})^{\dagger}$ & $\operatorname{RR}(95 \% \mathrm{Cl})^{\dagger}$ & $\mathrm{RR}(95 \% \mathrm{CI})^{*}$ & $\operatorname{RR}(95 \% \mathrm{Cl})^{t}$ \\
\hline Low alcohol-high methionine-high folate & 1.00 (reference) & 1.00 (reference) & 1.00 (reference) & 1.00 (reference) \\
\hline Intermediate alcohol-methionine-folate & $0.83(0.26-2.67)$ & $0.47(0.10-2.18)$ & $1.59(0.37-6.90)$ & $0.79(0.16-3.82)$ \\
\hline High alcohol-low methionine-low folate & $1.26(0.59-2.70)$ & $1.01(0.40-2.54)$ & $2.69(0.99-7.29)$ & $0.45(0.14-1.50)$ \\
\hline \multicolumn{5}{|c|}{$\begin{array}{l}\text { 'adjusted for age, energy intake, family hislory of colorectal cancer, iron intake, vitamin c intake and dietary fiber intake. } \\
\text { - Low alcohol intake is defined as } s 4 \mathrm{~g} / \mathrm{d} \text { and high alcohol intake is defined as } \geq 15 \mathrm{~g} / \mathrm{d} \text {. Intermediate alcohol intake is defined as between } 5 \\
\text { and } 14 \mathrm{~g} / \mathrm{d} \text {. } \\
\text { Low intake of folate are quintiles } 1+2(<198 \mu \mathrm{g} / \mathrm{d} \text { for men. }<176 \mu \mathrm{g} / \mathrm{d} \text { for women). High intake of folate are quintiles } 4+5(2226 \mu \mathrm{g} / \mathrm{d} \text { for } \\
\text { men, } \geq 203 \mu \mathrm{g} / \mathrm{d} \text { for women). Intermediate intake of folate are quintiles } 3(198-226 \mu \mathrm{g} / \mathrm{d} \text { for men and } 176-203 \mu \mathrm{g} / \mathrm{d} \text { for women). } \\
\text { Low intake of methionine are quintiles } 1+2(<1.58 \mathrm{~g} / \mathrm{d} \text { for men, }<1.38 \mathrm{~g} / \mathrm{d} \text { for women). High intake of methionine are quintiles } 4+5(21.78 \\
\mathrm{g} / \mathrm{d} \text { for men, } \geq 1.56 \mathrm{~g} / \mathrm{d} \text { for women). Intermediate intake of methionine are quintiles } 3(1.58-1.78 \mathrm{~g} / \mathrm{d} \text { for men and } 1.38-1.56 \mathrm{~g} / \mathrm{d} \text { for women). }\end{array}$} \\
\hline
\end{tabular}

The following unstratified associations between alcohol and rectal cancer risk were found; Men: RR hi vs. lo $=1.21 ; 95 \% \mathrm{Cl}, 0.88-1.66$; Women: $1.06 ; 95 \% \mathrm{Cl}, 0.62-$ 1.82. The number of cases for men and women were 257 and 143 respectively. These results suggest that men consuming higher amounts of alcohol combined with inadequate intakes of folate and methionine are at higher risk of developing rectal cancer. Results are based on small number of cases, however. Among men with low folate intake $(<168 \mu \mathrm{g} / \mathrm{d})$ and high alcohol intake $(\geq 15 \mathrm{~g} / \mathrm{d})$, risk of rectal cancer was approximately 1.5 times the risk of rectal cancer for those with low folate intake combined with low alcohol intake $(\leq 4 \mathrm{~g} / \mathrm{d}$ ) (data not shown).

\section{DISCUSSION}

The general conclusion from our data is that dietary folate intake is inversely associated with risk of colon cancer in men and women and rectal cancer in men. A protective effect of folate against rectal cancer was not found among women.

Many case-control studies have found inverse associations between folate intake and the risk of colorectal cancer (Benito et al. 1991, Meyer \& White 1993, Ferraroni et al. 1994, Glynn et al. 1996, Boutron-Ruault et al. 1996, Levi et al. 2000, White et al. 1997, La Vecchia et al. 1997). These studies found on average a $35 \%$ reduction in the risk of developing colorectal cancer in subjects with the highest dietary folate intake compared with those with the lowest intake (Kim 1999). Five studies found a statistically significant reduction. Evidence from two prospective studies (Giovannucci et al. 1995, Giovannucci et al. 1998) supports an 
inverse association between folate intake and the risk of colon cancer. No prospective studies have been reported on rectal cancer, however. In the Health Professionals Follow-up Study, dietary folate intake was not significantly related to the risk of colon cancer with a RR (highest versus lowest quintile) of 0.86 (Giovannucci 1995). The Nurses' Health Study did not find a significant association with colon cancer either: the multivariate RR for highest versus lowest quintile was $0.82(95 \% \mathrm{Cl}, 0.56-1.20)$. The inverse association in the present study was stronger with RRs around 0.70. This stronger association in our study appeared when we controlled for iron intake in the multivariate analysis, especially for men. In cohort studies reported previously, the use of supplemental folic acid for more than 15 years was associated with a lower risk of colon cancer. In the Netherlands, folic acid supplements were rarely used at the time of the baseline measurements and during the 7.3 years of follow-up (Konings et al. 2001) due to legislative restrictions for multivitamins including folic acid. Therefore the overall effect of folic acid supplements in our study is assumed to be negligible.

The strengths of our study include its prospective design. Preclinical symptoms are not likely to have influenced the dietary habits, because results were hardly found to be affected after exclusion of cases diagnosed in the first year of followup. Furthermore, selection bias was not likely because the follow-up of cases and subcohort members was almost complete. Another strength of the present study was the use of a newly compiled folate database with food folate values, based on Dutch products, established with a validated trienzyme HPLC method preceded by an affinity chromatography clean-up step (Konings 1999).

This is the first epidemiological study to estimate associations between the intake of individual folate vitamers and cancer risk. The RRs for colon and rectal cancer were on average lower for intake levels of polyglutamates than for those of monoglutamates. This could be explained by a higher intake on the one hand and a possibly good bioavailability of polyglutamates on the other. Because of the up to now supposed reduced bioavailability of polyglutamates and the two-fold higher intake level compared to monoglutamates, it was expected that the RRs for polyglutamates and monoglutamates would be comparable. Cuskelly et al. 1996 found no increased folate status in women taking extra dietary folate, and hypothesized that this was caused by the low bioavailability of food folates. Brouwer et al. (1999), Broekmans et al. (2000) and recent studies we have completed with ileostomy subjects (Konings et al. personal communication) clearly refuted these findings and reported bioavailability levels of food folate as high as $80 \%$ relative to supplemental folic acid. Among the associations between individual folate vitamers and colon or rectal cancer, the RR of 5-methyltetrahydrofolate corresponds most closely with the overall association between total folate and colon or rectal cancer. This was to be expected, as food folate intake consists mainly of this vitamer. A striking finding however, are the (highly significant) inverse associations between 5-formyltetrahydrofolate and colon cancer among men. 
Because the intake of this vitamer is $80 \%$ below that of 5 -methyltetrahydrofolate, this suggests a higher bioavailability of 5-formyltetrahydrofolate compared to 5methyltetrahydrofolate, or is perhaps metabolically more potent.

An inverse association between folate and colon and rectal cancer in the lower half of methionine intake seemed to be limited to men, although interaction was not statistically significant. A greater benefit of folate in the lower half of methionine intake underlines the role of folate in methionine synthesis. An insufficient folate level combined with low methionine intake might result in inadequate DNA methylation, leading to a greater risk of colon cancer, as hypomethylation is regarded as one of the earliest events in colon caricinogenesis. Giovannucci found a significant interaction between folate and methionine in the Nurses' Health Study $(P=0.005)$ which became weaker when folic acid supplement users were excluded from the analysis $(P=0.02)$, suggesting a stronger effect with higher folate intake at low methionine intake levels. As the present study considered only dietary folate intakes, this might explain the weaker interaction effects.

We found somewhat higher risks of colon cancer among men with high alcohol intake combined with low folate and methionine intakes, although not significant. The effect was stronger for rectal cancer. In the Health Professionals Study, Giovannucci et al. (1995) found an approximately twofold higher risk of colon cancer among men with a high alcohol intake combined with low folate and methionine intakes, compared to men with low alcohol intake combined with high folate and methionine intakes. Mean alcohol intake for the high intake level in our study was $32 \mathrm{~g} / \mathrm{d}$, slightly higher than the highest intake level in the Health Professionals Study, which was $29 \mathrm{~g} / \mathrm{d}$. The approximately 2.5 times higher folate intake level in the Health Professionals Study in the 'high' intake group $(755 \mu \mathrm{g} / \mathrm{d}$ versus $290 \mu \mathrm{g} / \mathrm{d}$ in our study for the high folate intake level) might explain the differences in RR. Our study found a 2.5 times higher risk of rectal cancer among men with high alcohol intake combined with low folate and methionine intakes. The inverse association between high alcohol intake combined with low folate and methionine intake and rectal cancer risk among women is hard to explain. This subgroup had the smallest number of cases on the one hand and the absence of an inverse association between folate intake and rectal cancer risk among women would not plead for an effect of the folate antagonist alcohol on the other hand. However, unstratified analysis revealed a positive association between alcohol consumption and rectal cancer risk among women. Other studies have found elevated risks associated with alcohol predominantly in the rectum or distal colon (Kune \& Vitetta 1992). The RRs for distal colon cancer in our study were not higher than those for total colon cancer (data not shown) among subjects with high alcohol intake combined with low folate and methionine intakes.

Although there is evidence of subsite-specific differences in colon cancer risk associated with vegetable consumption (Voorrips et al. 2000), this was not 
observed for folate intake, suggesting that another component in vegetables might be responsible for this effect.

We included many dietary as well as nondietary determinants of colon and rectal cancer as potential confounders in the multivariate models. It is still possible, however, that another factor, not controlled for in our analysis, might be involved. A striking finding of the present study was a strong confounding effect of iron intake in the associations between folate intake and colorectal cancer among men, which was not found among women. This is consistent with findings by Nelson et al. (1992, 1994) and Stevens et al. (1988), who reported positive associations between iron stores and dietary iron intake on the one hand and colon cancer and colonic adenoma on the other, which might only apply to men. It has been hypothesized, firstly, that iron could catalyze the production of oxygen radicals, which can function as proximate carcinogens. Secondly, iron may be a limiting nutrient for the growth and development of cancer cells, so excess iron may stimulate the growth of cancer cells. Indicators of body iron stores are serum ferritin and total iron-binding capacity, which is inversely related to serum ferritin levels. Physiologically, women have lower iron stores, which might explain differences in cancer development.

Because many folate-containing foods also contain other possible risk-reducing vitamins which might affect our findings, associations between folate and colorectal cancer were investigated in subjects with low and high intakes of vitamin $E$, vitamin $C, B$-carotene and vitamin $A$. No significant interactions were found (data not shown), which underline the independent effect of dietary folate.

In summary, we found evidence for an inverse association between dietary folate intake and colon cancer risk in both sexes and rectal cancer risk in men only. The associations found in the present study suggest that an increase in folate intake of $50 \mu \mathrm{g} / \mathrm{d}$ might results in an approximately $10 \%$ reduction of the risk of colorectal cancer. 5-methyltetrahydrofolate and 5-formyltetrahydrofolate in foods accounted for most of these inverse associations. There was no difference in the risk for specific colon subsites. Risk appeared to be independent of vitamin $A, C, E$ and $B$-carotene intakes as a proxi for fruit and vegetables. Although highly significant inverse associations between folate and colon and rectal cancer were found in the lower half of methionine intake levels, these interactions were not significant, suggesting that the beneficial role of folate may not be limited to persons with a low methionine intake. The numbers in the studied subgroups were still relatively small, however. The present study confirmed that alcohol acts as a methyl group antagonist, at least in men. Among men, the risk of rectal cancer was 2-3 times higher when alcohol intake was relatively high and the intake of folate and methionine were low respectively. This antagonism was less pronounced for colon cancer, however. Higher intake of dietary folate may reduce the risk of colon and rectal cancer. 


\section{ACKNOWLEDGEMENTS}

The Netherlands Cohort Study on diet and cancer is partly supported by the Dutch Cancer Society.

The authors would like to thank the regional cancer registries, the Dutch national database of pathology reports (PALGA), and the Dutch Health Care Information Center for providing cancer incidence data.

We also acknowlege the kind assistence provided by $S$. van den Crommert, M.P.A. Zeegers, E. Dorant, W. van Dijk, M. Moll, J. Nelissen, C. de Zwart, H. van Montfort, R. Smeitz, and M. de Leeuw for programming and statistical assistence.

\section{REFERENCES}

Benito $E$, Stiggelbout $A$, Bosch FX, Obrador A, Kaldor J, Mulet M, Muňoz N. Nutritional factors in colorectal cancer risk: a case-control study in Majorca. Int J Cancer 1991;49:161-7.

Blount BC, Mack MM, Wehr CM, MacGregor JT, Hiatt RA, Wang G, Wickramasinghe SN, Everson RB, Ames BN. Folate deficiency causus uracil misincorporation into human DNA and chromosome breakage: implications for cancer and neuronal damage. Proc Natl Acad Sci USA 1997;94:3290-5.

Boutron-Ruault M-C, Senesse P, Faivre J, Couillault C, Belghiti C. Folate and alcohol intakes: related or independent roles in the adenoma-carcinoma sequence? Nutr Cancer 1996;26:337-46.

Broekmans WMR, Klöpping-Ketelaars IAA, Schuurman CRWC, Verhagen $H$, van den Berg $H$, Kok FJ, van Poppel $G$. Fruits and vegetables increase plasma carotenoids and vitamins and decrease homocysteine in humans. J Nutr 2000;130:1578-83.

Brouwer IA, van Dusseldorp M, West CE, Meyboom S, Thomas CMG, Duran M, van het Hof KH, Eskes TKAB, Hautvast JGAJ, Steegers-Theunissen RPM. Dietary folate from vegetables and citrus fruit decreases plasma homocysteine concentrations in humans in a dietary controlled trial. $\mathrm{J}$ Nutr 1999;129:1135-9.

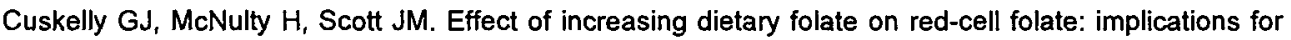
prevention of neural tube defects. The Lancet 1996;347:657-9.

Chen J, Giovannicci E, Kelsey K, Rimm EB, Stampfer MJ, Colditz GA, Spiegelman D, Willett WC, Hunter DJ. A methylenetetrahydrofolate reductase polymorphism and the risk of colorectal cancer. J Cancer Research 1996;56:4862-4.

Dorant E, van den Brandt PA, Hamstra AM, Feenstra MH, Goldbohm RA, Hermus RJJ, Sturmans R. The use of vitamins, minerals and other dietary supplements in the Netherlands. Int $J$ Vitam Res 1993;63:4-10.

Eichner ER, Hillman RS. The evaluation of anemia in alcoholic patients. Am J Med 1971;50:218-232.

Feinberg AP, Vogelstein B. Hypomethylation distinguishes genes of some human cancers from their normal counterparts. Nature 1983;301:90-1.

Ferraroni M, La Vecchia C, D'Avanzo B, Negri E, Franceschi S, Decarli A. Selected micronutrient intake and the risk of colorectum cancer. $\mathrm{Br} J$ Cancer 1994;70:1150-5.

Freundenheim JL, Graham S, Marshall JR, Haughy BP, Cholewinski S, Wilkinson G. Folate intake and carcinogenesis of the colon and rectum. Int J Epidemiol 1991;20:368-74.

Giovannuci E, Stampfer MJ, Colditz GA, Rimm EB, Trichopoulos D, Rosner BA, Speizer FE, Willett WC. Folate, methionine and alcohol intake and risk of colorectal adenoma. J Natl Cancer Inst 1993;85:875-84.

Giovannuci E, Rimm EB, Ascherio A, Stampfer MJ, Colditz GA, Willett WC. Alcohol, low-methionine, low-folate diets, and risk of colon cancer in men. J Natl Cancer Inst 1995;87,4:265-73. 
Giovannuci E, Stampfer MJ, Colditz GA, Hunter DJ, Fuchs C, Rosner BA, Speizer FE, Willett WC. Multivitamin use, folate, and colon cancer in women in the Nurses' Health Study. Ann intern Med 1998;129:517-24.

Glynn SA, Albanes D, Pietinen P, Brown CC, Rautalahti M, Tangrea JA, Gunter EW, Barrett MJ, Virtamo J, Taylor PR. Colorectal cancer and folate status: a nested case-control Study among Male smokers. Canc Epid Biom Prev 1996;5:487-94.

Goldbohm RA, van den Brandt PA, Dorant E. Estimation of the coverage of Dutch municipalities by cancer registries and PALGA based on hospital discharge data. Tijdschr Soc Gezond $1994 a ; 72: 80-4$.

Goldbohm RA, van den Brandt PA, Brants HAM, Van 't Veer P, Al M, Sturmans F, Hermus RJJ. Validation of a dietary questionnaire used in a large prospective cohort study on diet and cancer. Eur J Clin Nutr 1994b;48:253-65.

Goldbohm RA, Brants HAM, Hulshof KFAM, van den Brandt PA. The contribution of various foods to intake of vitamin A and carotenoids in the Netherlands. Int J Vit Res 1998;68:378-83.

Gregory JF III. The bioavailability of folate. IN: Bailey $L$, ed. Folate in health and disease. M. Dekker New York, NY. 1995:195-235.

Herbert V, Colman N. Folic acid and vitamin B12. In: Shils ME and Young VR (eds.) Modern nutrition in health and disease. $7^{\text {th }}$ Ed:388-416. 1988, Lea \& Pebiger, Philadelphia.

International Clasification of diseases for Oncology. First Edition. Geneva: World Health Organization 1976.

Kim Y $\mathrm{I}$. Folate and carcinogenesis: Evidence, mechanisms, and implications. I Nutr Biochem 1999;10:66-88.

Kune GA. Vitetta L. Alcohol consumption and the etiology of colorectum cancer: a review of the scientific evidence from 1957 to 1991. Nutr Cancer 1992;18:97-111.

Konings EJM. A validated LC metrhod for the determination of folates in vegetables, milk powder, liver and flour. JAOAC Int 1999;82:119-27.

Konings EJM, Roomans HHS, Dorant E, Glodbohm RA, Saris WHM, van den Brandt PA. Folate intake of the Dutch population based on newly established liquid chromatography data for foods. Am J Clin Nutr 2001;73:765-76.

La Vecchia C, Braga C, Negri E, Franceschi S, Russo A, Conti E, Falcini F, Giacosa A, Montella M, Decarli A. Intake of selected micronutrients and risk of colorectal cancer. Int $\mathrm{J}$ Cancer 1997;73:525-30.

Levi F, Pasche C, Lucchini F, La Vecchia C. Selected micronutrients and colorectal cancer: a casecontrol study from the Canton of Vaud, Switzerland. Eur J Cancer 2000; 36:2115-9.

Ma J, Stampfer MJ, Giovannucci E, Artigas C, Hunter DJ, Fuchs C, Willett WC, Selhub J, Hennekens $\mathrm{CH}$, Rozen R. Methylenetetrahydrofolate reductase polymorphism, dieatry interactions and risk of colorectal cancer. Cancer Research 1997;57:1098-1102.

Meyer F, White E. Alcohol and nutrients in relation to colon cancer. Am J Epid 1993;138:225-36.

Nelson RL, Davis FG, Sutter E, Sobin J, Kikendall JW, Bowen P. Body iron stores and risk of colonic neoplasia. J Natl Cancer Inst 1994;86,6:455-60.

Nelson RL. Dietary iron and colorectal cancer risk. Free Radic Biol Med 1992;12:161-8.

Netherlands Cancer Registry, 1996 report.

NEVO tabel. Dutch Food Composition Table 1986-1987; Nederlands Voedingsstoffenbestand 19861987. The Hague: Voorlichtingsbureau voor de voeding, 1986 (in Dutch).

Potter JD. Colorectal cancer: Molecules and populations. JNCl 1999;91,11:919-32.

Romero JJ, Tamura T, Halsted $\mathrm{CH}$. Intestinal absorption of [ $\left.{ }^{3} \mathrm{H}\right]$ folic acid in the chronic alcohol monkey. Gastroenterology 1981;80:99-102.

Shaw $S$, Jayatilleke $E$, Herbert $V$, Colman $N$. Cleavage of folates during ethanol metabolism: role of acetaldehyde-xanthine oxidase generated superoxide. J Biochem 1989;257:277-80.

Slatterly ML, Potter JD, Samowitz W, Scaffer D, Leppert M. Methylenetrtrahydrofolate reductase, diet, and risk of colon cancer. Cancer Epidemiol Biomarkers Prev 1999;8:513-8. 
Statacorp (1999) Stata statistical software: Release 6.0. Stata corporation, College Station, Teas, USA.

Stevens RG, Jones DY, Micozzi MS, Taylor PR. Body iron stores and the risk of cancer. N Engl J Med 1988;319:1047-52.

van den Brandt PA, Goldbohm RA, van het Veer PAV, Volovic A, Hermus RJJ and Sturmans F. A largescale prospective cohort study on diet and cancer in the Netherlands. J Clin Epidemiol 1990a;43:285-95.

van den Brandt PA, Schouten LJ, Goldbohm RA, Dorant E, Humen PM. Development of a record linkage protocol for use in the Dutch Cancer Registry for Epidemiological Research. Int J Epidemiol 1990b;19:553-8.

Volovics A, van den Brandt PA. Methods for the analyses of case-cohort studies. Biometrical J 1997;2:195-214.

Voorrips LE, Goldbohm RA, van Poppel G, Sturmans F, Hermus RJJ, van den Brandt PA. A prospective cohort study on vegetable and fruit consumption and risk of colon and rectum cancer: the Netherlands Cohort Study on Diet and Cancer. Am J Epidemiol 2000;152;1081-92.

White E, Shannon JS, Patterson RE. Relationship between vitamin and calcium supplement use and colon cancer. Cancer Epidemiol Biomarkers Prev 1997:6:769-74. 
General discussion 


\section{ANALYSIS OF DIETARY FOLATES AND FOLIC ACID}

High quality food composition data are needed in epidemiological analyses when nutrient intakes are to be related to disease endpoints. However, folates differ widely with respect to their susceptibility to oxidative degradation, their thermal stability and the $\mathrm{pH}$ dependence of their stability, factors which contribute to variations in the folate content between foods. Possible differences in folate content of foods may depend upon growth and storage conditions. In addition the method of food preparation can affect the content of the food as eaten because of folate's water solubility. And as described above, analytical methods and sample preparation are also important sources of variation. All of these factors could contribute to errors in the measurement of a subjects' folate intake, which would probably increase non-differential misclassification and would thus bias results towards finding "no association" (Freudenheim 1991). In an attempt to address some of these sources of error, we compiled a new food folate database, presented in chapter 3. Data in this table comply with specific quality criteria for analytical methods, analytical quality control, sample handling and sampling plan, to produce high quality food folate composition data, the importance of which was recently emphasized by Holden et al. (1997).

An increasing number of authorities allow food fortification with folic acid to improve folate status. In the Netherlands a Commission of the Dutch Health Council recently recommended to allow food fortification with folic acid because the advice to take supplements to prevent neural tube defects appeared to be insufficiently complied with. For the time being, this fortification is limited to those foods that are specifically aimed at the target group of women who wish to become pregnant (Gezondheidsraad 2000). Data from Jacques et al. (1999) and Lawrence et al. (1999) show an increase in plasma and serum folate levels since the start of the folic acid fortification program in the USA (Figure 1) where fortification of cereals and grains began some time after 1996. The Food and Drug Administration stipulated that fortification of all cereal grains had to be completed by January 1 , 1998. 


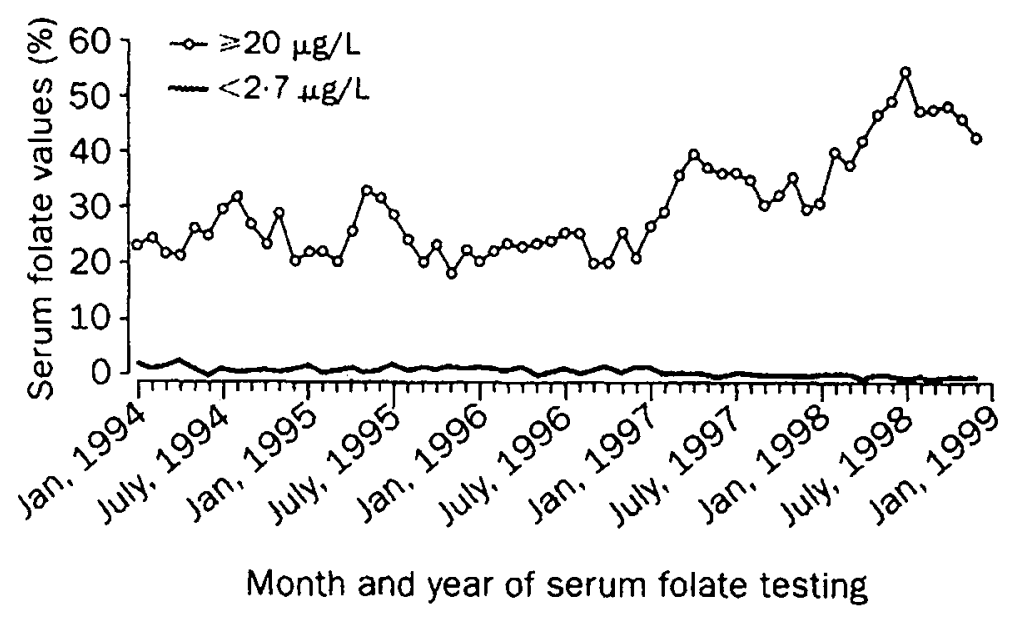

Figure 1. Percentage of serum folate values $<2.7 \mu \mathrm{g} / \mathrm{L}$ and $\geq 20 \mu \mathrm{g} / \mathrm{L}$, by month, 1994-98. (Lawrence et al. 1999)

There are some worries that certain sections of the population are getting too much folic acid. Rader et al. (2000) analyzed the total folate content of enriched grain products, and found the folate content of many products to be significantly higher than either allowed by the federal regulations or listed in the label, exceeding these by more than $200 \%$.

So far, only microbiological analysis, which measures only total folate, is accepted as a reference method for determining the level of this vitamin. Apart from the urgent need to measure dietary folates with a higher specificity, one would like to be able to measure the "added" folic acid in order to enforce the allowed additions and the accompanying maximum intake level of $1 \mathrm{mg}$ of folic acid per day. The analytical method described in chapter 2 would be a good candidate to measure individual folate vitamers as well as folic acid. Analyses of four reference materials proved that the method yielded reproducible results. A next step would be to organize a collaborative study according to the AOAC Official Methods Program (1997). The purpose of this program is to stimulate interlaboratory collaborative studies validating proposed methods through independent testing in separate laboratories under identical conditions. The purpose of such studies is to establish the characteristics of the methods with respect to accuracy, precision, sensitivity, range, specificity, ruggedness, limits of measurement, practicality, and similar attributes in typical laboratory applications. Such validated methods, AOAC official methods, can then be used with confidence by regulatory agencies, regulated industry and product testing laboratories to determine compliance with government regulations. To date, no chromatographic method has been validated on the basis of such a protocol. 


\section{BIOAVAILABILITY}

The basis for the current Estimated Average Requirement in the USA (Institute of Medicine, Panel on Folate, other B-vitamins, and choline 1998) is a study by Sauberlich et al (1987). They concluded that the bioavailability of food folate was no more than $50 \%$ of that of folic acid. Cuskelly et al. (1996) confirmed their findings by suggesting that food folate is less bioavailable than the synthetic form, as shown by a smaller increase in erythrocyte folate in the group that received an increased level of folate from food than in the group receiving it from the synthetic form. However, food consumption was not controlled. Recently, Brouwer et al. (1999) showed that the bioavailability of folate from vegetables and citrus fruits was $78 \%$ relative to folic acid, based on plasma folate concentrations. The results described in Chapter 4 reveal that the bioavailability of spinach folate is approximately $90 \%$ of that of folic acid. It can be concluded that the bioavailability of food folate might be higher than the assumed $50 \%$.

The difference might be explained by the fact that studies finding higher bioavailability used only vegetables and citrus fruits as a source of folate. However, the source of folate data may actually influence the relative percentage of bioavailability. Based on the study described in Chapter 3, we found $25-30 \%$ lower total food folate values compared to levels listed in the current food composition tables, though these differences were only significant for the British food composition table. If intake levels of food folate are assumed to be $25-30 \%$ higher, the bioavailability relative to folic acid decreases by the same percentage. A study by Ridell et al. (2000) attributed approximately half of the reduction of plasma homocysteine to the intake of all sources of food folate compared to the same amount of folic acid intake. Food folate intake was based on the New Zealand food composition table. When the total food folate intake is corrected for the supposed $30 \%$ higher food folate values and the $10 \%$ reduction in bioavailability found in our bioavailability study, plasma homocysteine decrease is caused by about equal amounts of food folate and folic acid intake. If food folate bioavailability is more than $50 \%$ of that of folic acid, then the newly established estimated requirements in the USA could be lowered.

\section{ASSOCIATION WITH COLORECTAL CANCER}

The supposed difference in bioavailability of folate monoglutamates versus folate polyglutamates and the possible variations in the bioavailability of individual folate vitamers might introduce another source of error into epidemiological analysis related to disease endpoints if only total dietary folate amounts are taken into account. Since we compiled these data in our new database, we were able to perform a separate analysis of the association between individual folate vitamers 
and the risk of colorectal cancer. The inverse association between 5 -formyltetrahydrofolate and colon cancer among men seemed to be stronger than that between the other vitamers and colon cancer. This cannot be explained on the basis of our current knowledge. It was concluded that the intestinal tissue has the capacity to convert 5-formyltetrahydrofolate to 5-methyltetrahydrofolate (Stern et al. 2000).

Results described in Chapter 5 confirm the role of a reduced folate intake as a potential risk factor of colorectal cancer. Recently, Colditz et al. (2000) indicated in their Harvard Report on cancer prevention that a low folate intake is a definite risk factor for colon cancer; however, results were not consistent in all studies. In an earlier report, Tomeo et al. (1999) gave the preventive recommendation to take a daily multivitamin supplement containing $0.4 \mathrm{mg}$ of folic acid. This was partly based on the results of the Nurses' Health Study. Women who had used multivitamins for at least 15 years had a considerably lower risk of developing colon cancer than women who had never used multivitamins (RR: $0.25 ; 95 \% \mathrm{Cl}, 0.13-0.51$ ). Women whose diets were high in folate but who never took multivitamins showed no significant reduction in risk (Giovannucci et al. 1998). This contradicts the results presented in Chapter 5, which revealed that dietary folate was significantly inversely related to colon cancer (and to male rectal cancer). This means that the use of folate-rich vegetables and fruits may also reduce the risk of colorectal cancer. Our results, indicating a protective role of dietary folate, were confirmed by several other studies, mostly case-control studies. In these studies, dietary folate intake seemed to be inversely related to colorectal cancer, with a $35-40 \%$ risk reduction in those with the highest folate intake compared with those with the lowest intake (Benito et al. 1991, Freudenheim et al. 1991, Meyer \& White 1993, Ferraroni et al. 1994, Glynn et al. 1996, Boutron-Ruault et al. 1996, White et al. 1997, La Vecchia et al. 1997, Giovannucci et al. 1995).

In our study it was found that men who use a low-methyl diet (low folate-low methionine and high alcohol) were almost three times as likely to develop rectal cancer as men who on a high-methyl diet. The mechanisms of ethanol-associated carcinogenesis are not entirely clear. Recently, Homann et al. (2000) suggested that microbially produced acetaldehyde from ethanol probably cleaves folate to inactive forms. Acetaldehyde itself is thought to be highly toxic and carcinogenic. Increased alcohol intake and low-folate diet exert a synergistic effect on colorectal carcinogenesis.

An interesting aspect of common MTHFR polymorphisms and carcinogenesis is that dietary factors such as folate and alcohol can modify the risk of cancer conferred by specific MTHFR polymorphisms. The protective effect of the MTHFR $677 T \mathrm{~T}$ genotype on colorectal cancer was evident only in individuals with adequate folate status and was largely suppressed in those with low dietary folate intake or high alcohol consumption. This possible gene-nutrient interaction provides an 
opportunity to identify a suitable target group of individuals at high risk of developing colorectal cancer, who could benefit from chemo-prevention using folate or other nutrients involved in the MRHFR metabolic pathway (Kim 2000).

A striking finding of the analyses described in chapter 5 was the confounding effect of iron, especially in men. Since iron intake may be positively related to colorectal cancer it is worrying that an increasing number of products like milk, fruit drinks, corn flakes and biscuits are being fortified with iron. Data from the third Dutch National Food Consumption Survey 1998 (DNFCS) revealed that the mean iron intake by men, (22-50y) $13 \mathrm{mg} / \mathrm{d}$, amply exceeds the recommendations (9 mg/d), whereas the intake by women, (22-50y) $10.7 \mathrm{mg} / \mathrm{d}$, was considerably below the recommended amount $(15 \mathrm{mg} / \mathrm{d}$ ) (Voedingsraad 1989, Voedingscentrum 1998).

Compiling data from several food composition tables based on various analytical methods could contribute to error in measurement of a subjects' folate intake resulting in an increase of non-differential misclassification and bias results towards finding "no association". To illustrate this, we calculated relative risks of colon and rectal cancer for highest versus lowest quintile of folate intake based on our new HPLC data, and by using microbiological data from several international food composition tables compiled by Brants \& Hulshof (1995). Results are shown in figure 2. Based on data from international food composition tables, relative risks are generally closer to 1 and $95 \%$ confidence intervals are broader compared to calculations based on HPLC data. This emphasizes the need for high quality data in epidemiological analyses when nutrient intakes are to be related to disease endpoints. 

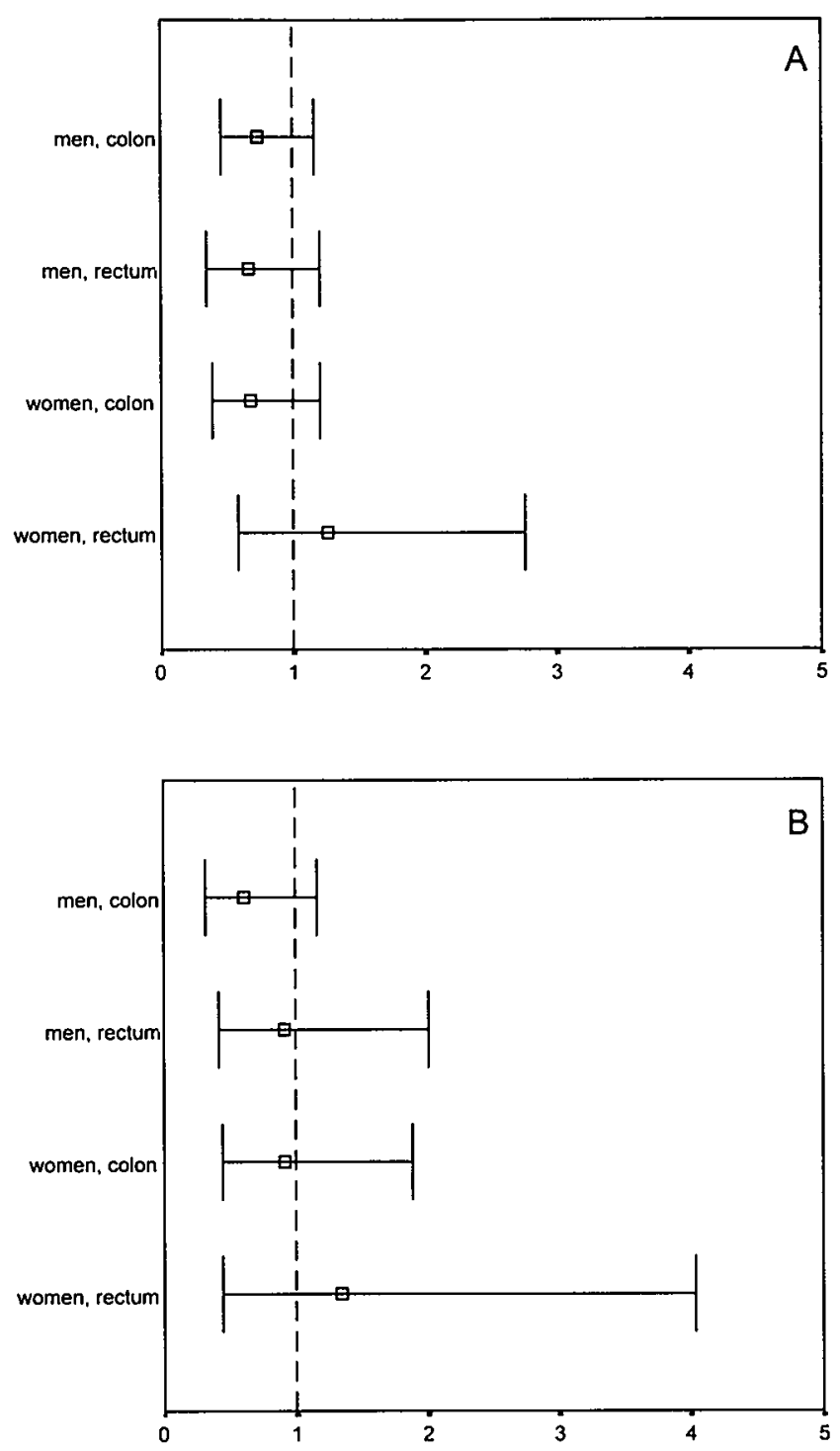

Figure 2. Relative Risks $(95 \% \mathrm{Cl})$ of colon and rectal cancer for highest versus lowest quintile of folate intake based on our new HPLC data (A), and by using microbiological data from international food composition tables (B). 


\section{DIETARY FOLATE INTAKE IN RELATION TO RECOMMENDED DAILY ALLOWANCES}

"Depletion-repletion studies" have shown that blood folate levels in adults are normalized after an oral dose of $50 \mu \mathrm{g}$ supplemental folic acid per day (Herbert et al. 1962). Sauberlich et al. (1987) estimated a $50 \%$ bioavailability of dietary folate. Hence, $100 \mu \mathrm{g}$ of dietary folate is deemed to be sufficient to maintain adequate serum folate levels. In a controlled metabolic study. Milne et al. (1983) concluded that $200 \mu \mathrm{g} /$ day of dietary folate was adequate to maintain normal folate status and was one argument for reducing the RDA in the USA from 400 to $200 \mu \mathrm{g} / \mathrm{day}$. (Food and Nutrition Board 1989). Prior to 1993, the basis of folate requirements for pregnant women was formed by two studies by Chanarin et al. (1985) and Colman (1982). They reported that $100 \mu \mathrm{g} /$ day of supplemental folic acid, in addition to dietary folate, or diets providing $300 \mu \mathrm{g} / \mathrm{day}$, maintained adequate blood folate levels during pregnancy. Based on these data, the RDA for pregnancy was reduced from 800 to $400 \mu \mathrm{g} /$ day. (Food and Nutrition Board 1989). According to our calculations in chapter $3,40-50 \%$ of men and women do not meet current Dutch recommendations. However, $4 \%$ of adult men and $11 \%$ of adult women consumed less than the minimum requirement of $100 \mu \mathrm{g} / \mathrm{d}$. Brussaard et al (1997) confirmed these estimates by finding a low blood folate status among approximately $10 \%$ of adult men and women. The current recommended intake of $200 \mathrm{~g}$ of vegetables and 2 pieces of fruit a day should ensure a folate intake of more than $100 \mu \mathrm{g} / \mathrm{d}$ for everyone. As shown in Chapter 3, folate intake by pregnant women is currently too low, judging from the results of the 1992 Dutch National Food Consumption Survey.

\section{FORTIFICATION OF FOODS WITH FOLIC ACID?}

In 1983, Smithells et al. found a $70 \%$ lower neural tube defect recurrence rate in women who received folic acid supplements. However, the study was not randomized, implying a possible selection bias. The late 1980 s saw the publication of the results of three case-control studies and one cohort study investigating the association between periconceptional folic acid intake and the prevalence of neural tube defects (NTD) (Bower et al. 1989, Mills et al 1989, Milunsky et al. 1989, Mulinare et al. 1988). Three of these studies showed that folic acid or folic acid containing supplements decreased the prevalence of neural tube defects (Bower et al. 1989, Milunsky et al. 1989, Mulinare et al. 1988). Even dietary folate reduced the risk of NTDs, but a greater decrease was attributed to an additional folic acid containing supplement (Milunsky 1989). According to the results of a double-blind multi-center prevention trial (MRC Vitamin Study Research Group 1991) it seemed appropriate to recommended a folic acid supplement of $4-5 \mathrm{mg} /$ day to women at 
high risk of having a pregnancy with a neural tube defect, because of a previous affected pregnancy. A study by Czeizel and Dudás (1992) made many governments decide to launch information campaigns to recommend folic acid supplements of $400-500 \mu \mathrm{g}$ daily for all women planning to become pregnant. The FDA ruling stipulating the fortification of flour, breads, corn meals, rice, noodles, macaroni, and other grain products with $140 \mu \mathrm{g}$ folic acid/100g, which could raise the folic acid intake of the average woman of childbearing age by $100 \mu \mathrm{g} / \mathrm{day}$, is designed to keep total daily folic acid intake below the $1 \mathrm{mg}$ level. Some researchers have been calling for an increase in the level of fortification (Oakley GP 1999, American Academy of Pediatrics Committee on Genetics 1999, American Medical association 1999, Hale et al. 1998). For ethical reasons, however, it is no longer possible to investigate the minimal daily dose of folic acid that reduces the risk neural tube defects.

A striking new element in the debate are the papers reporting a decrease in the prevalence of neural tube defects before the recommendation to take folic acid supplements was made. Among certain populations in the British Isles, the decline in the prevalence of neural tube defects predated the introduction of fortified cereals (Abramsky et al.1999, Murphy et al. 2000). The occurrence of neural tube defects in England, Wales, Scotland and Ireland, which used to be among the highest in the world, started to decline in the early 1970s. One explanation could be a protective effect of changes in the consumption of other dietary factors, including the B-group vitamins. A recent decline in NTDs in Australia could not be explained by periconceptional use of supplements either (Halliday 2000). It was unlikely that the full recommended dose of $400 \mu \mathrm{g}$ had been obtained through the ingestion of fortified foods, because only a few breakfast cereals were fortified with folic acid. Of course, the preventive action of folic acid may have complemented the "spontaneous" decline.

Mills and colleagues (Daly et al. 1999) calculated that an additional folic acid intake of $100 \mu \mathrm{g} / \mathrm{d}$ would reduce the rate of NTDs by $22 \%$ in the USA. Up till now there are no data on changes in the rates of NTDs as a result of the fortification program in the USA. Due to limitations of methods investigating the relationship of folic acid and NTD it must be considered possible that the theory that folate can prevent NTD is incorrect. Information expected during the coming years may prove this wrong (Kalter 2000).

Based on the findings described above, it would not be sensible to increase the level of fortification. Furthermore, in view of the negative effects of increasing folic acid intakes, such as progression of neurological complications due to a vitamin $B_{12}$ deficiency, it is surprising that public health officials have not demanded a higher standard of proof that the current level of fortification in the USA is safe and effective, given the fact that 274 million people are exposed to folic acid to prevent 2000 neural tube defects (Mills 2000). What is clear so far is that folic acid as well 
as dietary folate decreases plasma homocysteine levels. Clarke et al. concluded in a meta-analysis (Homocysteine Lowering Trialists' Collaboration, 1998) that folic acid doses between 0.5 and $5 \mathrm{mg}$ had the same homocysteine lowering effects, reducing blood homocysteine concentrations by $25 \%$. Vitamin $B_{12}$ produced an additional $7 \%$ reduction in blood homocysteine, while vitamin $B_{6}$ had no additional effect. From observational studies, de Bree et al. (1997) cautiously considered a dietary folate intake of $350 \mu \mathrm{g} / \mathrm{d}$ to maintain 'normal' homocysteine levels.

With the increase in plasma folate levels in the USA, an inverse trend of plasma homocysteine was observed by Komaromy-Hiller and Nuttal (1999). As high homocysteine levels are associated with cardiovascular diseases, much is expected from the current intervention trials on folic acid supplementation and the risk of cardiovascular disease. However, some findings have raised questions about homocysteine as a risk factor (Ueland et al. 2000, Brattström \& Wilcken, 2000). Some prospective studies showed the relation between homocysteine and cardiovascular disease to be weak or even absent. Several traditional risk factors like blood pressure (most importantly), smoking and elevated cholesterol levels are associated with homocysteine and may confound the relation between homocysteine and CVD. Homocysteine is related to renal function, and hyperhomocysteinemia may reflect early nephrosclerosis. The C677T transition of the methylenetetrahydrofolate reductase gene causes a moderate increase in homocysteine but little or no increase in CVD risk. The strength of some of these arguments may be questioned, and only placebo-controlled intervention studies with clinical endpoints can provide decisive arguments as to whether homocysteine is a causal risk factor for CVD.

A growing body of epidemiologic, clinical and animal studies suggests that folate deficiency is an important nutritional factor in colorectal carcinogenesis. Results of these studies are not uniform, but the general trend suggests that adequate intake of dietary folate might cause a $35-40 \%$ reduction in the risk of developing colorectal cancer. Three large multicenter trials are underway to determine the chemo-preventive role of folate supplementation in colorectal carcinogenesis. They are randomized, placebo-controlled and double-blind (Kim 1999). So far it seems that folic acid food fortification programs are premature within the framework of cardiovascular disease and colorectal cancer.

While taking folic acid supplements before conception is still the safest and the most effective way of preventing neural tube defects, it is clear that with respect to cardiovascular disease the results of intervention trials should be awaited. More evidence for or against a causal relationship between folate status and colorectal cancer will be provided by data from prospective controlled intervention trials that are currently underway. Before the results of intervention trials become available, it should be emphasized that folate intake must and can be enhanced by the consumption of folate-rich fruits and vegetables, like broad beans, Brussels 
sprouts, spinach, broccoli, strawberries, leek, asparagus, cauliflower, kale, endive, kiwi or orange.

Because of the negative effects of folic acid, it might be more useful to consider the use of 5-methyltetrahydrofolate for enrichment of foods or for use in vitamin supplements. No adverse effects have been associated with the consumption of excess folate from foods; adverse effects have exclusively been reported from the use of the synthetic compound folic acid (European Commission 2000). Synthetic 5-methyltetrahydrofolate (as a racemic mixture of the $6 S$ and $6 R$-compounds) is commercially available, but is to the present author's knowledge not being used in food supplements or food fortification. The natural form of reduced folates is thought to include mainly the 6S-diasterioisomer, which has a greater biological activity than the 6R-isomer. Intervention trials investigating the effects on cardiovascular disease and cancer should also anticipate the possibility of using 5methyltetrahydrofolate. In Chapter 3 is shown that 5 -methyltetrahydrofolate is the most abundant folate vitamer in foods. The use of 5-methyltetrahydrofolate could also overcome the drawback of folic acid, viz. that it masks vitamin $B_{12}$ deficiency. Although supplementing a vitamin $\mathrm{B}_{12}$ deficient subject with folic acid can result in the 'renewed availability' of 5,10-methylenetetrahydrofolate (5,10-methylene-THF), and the subsequent repair of DNA synthesis and remission of the hematological abnormalities (Figure 3 ), the neurological complications of a vitamin $B_{12}$ deficiency do not respond to folic acid supplementation. 


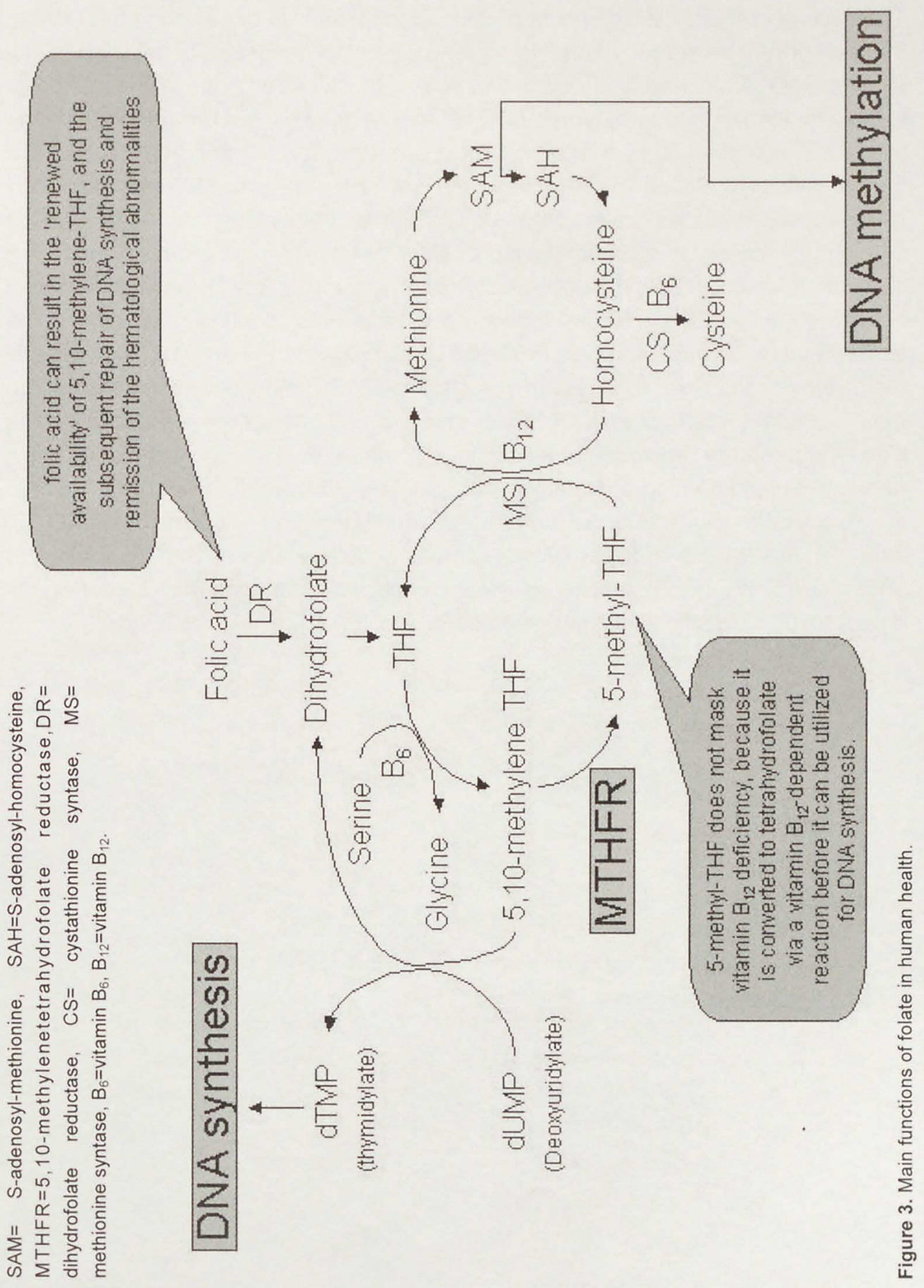


There are also other advantages of the use of 5-methyltetrahydrofolate. First, it would mean improved utilization by humans with the MTHFR variant, which occurs in $10-15 \%$ of the total population. 5-Methyltetrahydrofolate is potentially more effective in decreasing homocysteine in these individuals. Second, as concluded in chapter 5,5-methyltetrahydrofolate intake is inversely related to colon and male rectal cancer. Third, it would avoid the presence in the blood circulation of unmetabolized folic acid, whose long-term effects are not known. So far, few human studies have used 5-methyltetrahydrofolate. Verhaar et al. (1998) found that 5-methyltetrahydrofolate infusion restored endothelial function in familial hypercholesterolemia in vivo, possibly due to the reduced catabolism of NO. Perna et al. (1997) concluded that oral administration of $15 \mathrm{mg} \mathrm{5-methyltetrahydrofolate}$ for two months significantly reduced plasma homocysteine in 14 patients on hemodialysis. Relative to folic acid, 5-methyltetrahydrofolate supplementation did not improve the homocysteine-lowering efficacy in hemodialysis patients (Bostom et al. 2000). 5-Methyltetrahydrofolate is available as a calcium salt, which enhances stability. Its approval as novel food ingredient in Europe is in progress (Hasselwander 2000).

\section{FUTURE RESEARCH}

- $\quad$ Synthetic 5-methyltetrahydrofolate should be included in future studies to prove its bioavailability/bioefficacy. 5-Methyltetrahydrofolate, which is the most abundant natural folate vitamer, may overcome a number of disadvantages of folic acid, which making it a potentially appropriate functional food component for the future.

- Individuals with the homozygous mutant MTHFR genotype (677TT) and an inadequate folate status, especially in combination with high alcohol consumption and low methionine intake, may be at highest risk of developing colorectal cancer. An intervention study using particularly 5methyltetrahydrofolate among these individuals would allow evaluation of the chemo-preventive role of folate in de development of colorectal cancer.

- Because of the strong confounding effect of iron found in the association between dietary folate intake and the risk of colorectal cancer, especially in men, it is recommended to explore the association between iron intake and the risk of colorectal cancer in more detail, using the data from the Netherlands cohort study on diet and cancer. 


\section{REFERENCES}

Abramsky L, Botting B. Chapple J, Stone D. Has advice on periconceptional folate supplementation reduced neural-tube defects? The Lancet 1999;354:998-9.

American Academy of Pediatrics Committee on Genetics. Folic acid for the prevention of neural tube defects. Pediatrics 1999;104:325-7.

American Medical Association. H-440.898: recommendations on folic acid supplementation. Policies of the house of Delegates-A-99. Chicago: American Medical Association, 1999.

AOAC Official Methods Program. AOAC INTERNATIONAL, Gaithersburg, MD, USA, 1997.

Benito $E$, Stiggelbout $A$, Bosch FX, Obrador A, Kaldor J, Mulet M, Munoz N. Nutritional factors in colorectal cancer risk: a case-control study in Majorca. Int J Cancer 1991;49:161-7.

Bostom AG, Shemin D, Bagley P, Massy ZA, Zanabli A, Christopher K, Spiegel P, Jaques PF, Dworkin $\mathrm{L}$, Selhub J. Controlled comparison of L-5-methyltetrahydrofolate versus folic acid for the treatment of hyperhomocysteinemia in hemodialysis paptients. Circulation 2000;101:2829-32.

Boushey CJ, Beresford SAA, Omenn GS, Motulsky AG. A quantitative assessment of plasma homocysteine as a risk factor for vascular disease. Probable benefits of increasing folic acid intakes. JAMA 1995;274:1049-57.

Boutron-Ruault M-C, Senesse P, Faivre J, Couillault C, Belghiti C. Folate and alcohol intakes: related or independentroles in the adenoma-carcinoma sequence? Nutr Cancer 1996;26:337-46.

Bower C, Stanley FJ. Dietary folate as a risk factor for neural tube defects: Evidence from a casecontrol study in Western Australia. Med J Australia 1989;150:613-9.

Brants HAM, Hulshof KFAM. De ontwikkeling van een voedingsmiddelentabel met foliumzuurgehaltes. (The development of a food composition table for folate data.) Zeist, the Netherlands: TNO Nutrition and Food Research Institute, 1995 (in Dutch). (Report V 95.089)

Brattström L, Wilcken DEL. Homocysteine and cardiovascular disease: cause or effect? Am J Clin Nutr 2000:72:315-23.

Broekmans WMR. Klöpping-Ketelaars IAA, Schuurman CRWC, Verhagen $H$, van den Berg $H$, Kok FJ, van Poppel $G$. Fruits and vegetables increase plasma carotenoids and vitamins and decrease homocysteine in humans. J Nutr 2000;130:1578-83.

Brouwer IA, van Dusseldorp M, West CE, Meyboom S, Thomas CMG, Duran M, van het Hof KH, Eskes TKAB, Hautvast JGAJ, Steegers-Theunissen RPM. Dietary folate from vegetables and citrus fruit decreases plasma homocysteine concentrations in humans in a dietary controlled trial. $J$ Nutr 1999;129:1135-9.

Brussaard $\mathrm{JH}$, Löwik MRH, van den Berg H, Brants HAM, Goldbohm RA. Folate intake and status among adults in the Netheriands. Eur J Clin Nutr 1997;51:S46-S50.

Chanarin I, Rothman D, Ward A, Perry J. Folate status and requirement in pregnancy. $\mathrm{Br}$ Med J 1985;390-4.

Colditz GA, Atwood KA, Emmons K, Monson RR, Willett WC, Trichopoulos D, Hunter DJ. Harvard Report on Cancer Prevention Volume 4: Harvard Cancer Risk Index. Cancer Causes and Control 2000;11:477-88.

Colman N. Addition of folic acid to staple foods as a selective nutrition intervention strategy. Nutr Rev 1982;40:225-33.

Cuskelly GJ, McNulty $H$, Scott JM. Effect of increasing dietary folate on red-cell folate: Implications for prevention of neural tube defects. The Lancet 1996;346:657-9.

Czeizel AE, Dudás 1. Prevention of the first occurrence of neural tube defects by periconceptional vitamin supplementation. N Engl J Med 1992;327:1832-5.

Daly S, Mills JL, Molloy AM, Lee YJ, Kirke PN, Weir DG, Scott JM. Minimum effective dose of folic acid for food fortification to prevent neural-tube defects. The Lancet 1997;350:1666-9.

de Bree A, van Dusseldorp M, Brouwer IA, van het Hof KH, Steegers-Theunissen RPM. Folate intake in Europe: recommended, actual and desired intake. Eur J Clin Nutr 1997;51:643-60. 
European Commission, Scientific Committee on Food (SCF). Opinion of the SCF on the Tolerable Upper Intake Level of Folate (2000).

Ferraroni M, La Vecchia C, D'Avanzo B, Negri E, Franceschi S, Decarli A. Selected micronutrient intake and the risk of colorectal cancer. Br J Cancer 1994;70:1150-5.

Food and Nutrition Board. Recommended dietary allowances. $10^{\text {th }}$ edition. Wanshington DC: National Academy of Sciences, 1989.

Freudenheim JL, Graham S, Marshall JR, Haughy BP, Cholewinski S, Wilkinson G. Folate intake and carcinogenesis of the colon and rectum. Int J Epidemiol 1991;20:368-74.

Gezondheidsraad. Risico's van foliumzuurverrijking. Den Haag: Gezondheidsraad, 2000; publicatie nr $2000 / 21$.

Giovannucci E, Rimm EB, Ascherio A, Stampfer MJ, Colditz GA, Willett WC. Alcohol, low-methionine, low-folate diets, and risk of colon cancer in men. J Natl Cancer Inst 1995;87,4:265-73.

Glynn SA, Albanes D, Pietinen P, Brown CC, Rautalahti M, Tangrea JA, Gunter EW, Barrett MJ, Virtamo J, Taylor PR. Colorectal cancer and folate status: a nested case-control Study among Male smokers. Canc Epid Biom Prev 1996;5:487-94.

Hale RW, Zinberg S. Letter from the American College of Obstetricians and Gynecologists to the acting Commisioner, Food and Drug Administration, April 28, 1998. Washington, D.C.: American College of Obstetricians and Gynecologists, 1998.

Halliday JL, Rliley M. Fortification of foods with folic acid. Correspondence to the editor. NEJM 2000;343:970-2.

Hasselwander O. 5-Methyltetrahydrofolate, the active form of folic acid. Presenation Functional Foods 2000, The Hague, The Netherlands.

Herbert V, Cuneen N, Jaskiel L, Kapff C. Minimal daily adult folate requirements. Arch Intern Med 1962;110:649-52.

Homann N, Tillonen J, Salaspuro M. Microbially produced acetaldehyde from ethanol may increase the risk of colon cancer via folate deficiency. Int J Cancer 2000;86:169-73.

Homocysteine Lowering Trialists' Collaboration. Lowering blood homocysteine with folic acid based supplements: meta-analysis of randomized trials. Br Med J 1998;316:894-8.

Institute of Medicine, Panel on Folate, other B-vitamins, and choline. Dietary Refernce Intakes: thiamin, riboflavin, niacin, vitamin $B_{6}$, folate, vitamin $B_{12}$, panthothenic acid, biotin and choline. Washington, DC: National Academy Press, 1998.

Jacques PF, Selhub J, Bostom AG, Wilson PWF, Rosenberg $\mathrm{IH}$. The effect of folic acid fortification on plasma folate and total homocysteine concentrations. N Engl J Med 1999;340:1449-54.

Kalter $H$. Folic acid and human malformations: a summary and evaluation. Repro Tox 2000;14:463-76.

Kim Y-I. Folate and carcinogenesis: Evidence, mechanisms, and implications. J Nutr Biochem 1999;10:66-88.

Kim $Y-1$. Methylenetetrahydrofolate reductase polymorphisms, folate, and cancer risk: A paradigm of Gene-Nutrient interactions in carcinogenesis. Nutr Rev 2000;58,7:205-9.

Komaromy-Hiller G, Nuttall KL. Folic acid fortification. The Lancet 1999;354:2167-8.

La Vecchia C, Braga C, Negri E, Franceschi S, Russo A, Conti E, Falcini F, Giacosa A, Montella M, Decarli A. Intake of selected micronutrients and risk of colorectal cancer. Int J Cancer 1997;73:52530.

Lawrence JM, Petitti DB, Watkins $M$, Umekubo MA. Trends in serum folate after food fortification. Lancet 1999;354:915-6.

Meyer $F$, White $E$. Alcohol and nutrients in relation to colon cancer. Am J Epid 1993; 138:225-36.

Mills JL, Rhoads GG, Simpson JL, Cunningham GC, Conley MR, Lassman MR, Walden ME, Depp OR, Hoffman $\mathrm{HJ}$. The absence of a relation between the periconceptional use of vitamins and neuraltube defects. New Engl J Med 1989;321:430-5.

Mills JL. Fortification of food with folic acid. How much in enough? NEJM 2000; 342:1442-5.

Mulinare J, Cordero JF, Erickson JD, Berry RJ. Periconceptional use of multivitamins and the occurrence of neural-tube defects. JAMA 1988;260:3141-5. 
Milunsky A, Jick H, Jick SS, Bruell CL, Maclaughlin DS, Rothman KJ, Willett W. Multivitamin/folic acid supplementation in early pregnancy reduces the prevalence of neural-tube defects. JAMA 1989;262:2847-52.

Murphy $M$, Whiteman D, Stone D, Botting $B$, Schorah $C$, Wild J. Dietary folate and the prevalence of neural tube defects in the British Isles: the past two decades. Br J Obstet Gynaecol 2000;107:87784.

Oakley GP. Prevention of neural tube defects. N Engl J Med 1999;341:1546.

Rader JI, Weaver CM, Angyal G. Total folate in enriched cereal-grain products in the United States following fortification. Food Chem 2000;70:275-89.

Perna AF, Ingrosso D, De Santo NG, Galletti P, Brunone M, Zappia V. Metabolic Consequences of folate-induced reduction of hyperhomocysteinemia in uremia. J Am Soc Nephrol 1997;8:1899-1905.

Riddell LJ, Chisholm A, Williams S, Mann JI. Dietary strategies for lowering homocysteine concentrations. Am J Clin Nutr 2000;71:1448-54.

Sauberlich HE, Kretsch MJ, Skala JH, Johnson HL, Taylor PC. Folate requirement and metabolism in nonpregnant women. Am J Clin Nutr 1987;46:1016-28.

Smithells RW, Seller MJ, Harris R, Fielding DW, Schorah CJ, Nevin NC, Sheppard S, Read AP, Walker $S$, Wild J. Further experience of vitamin supplementation for prevention of neural tube defect recurrences. The Lancet 1983;1027-31.

Stern LL, Bagley PJ, Rosenberg IH, Selhub J. Conversion of 5-formyltetrahydrofolic acid to 5methyltetrahydrofolic acid is unimpaired in folate-adequate persons homozygous for the C677T mutation in the methylenetetrahydrofolate reductase gene. J Nutr 2000;130:2238-42.

Tomeo CA, Colditz GA, Willett WC, Giovannucci E, Platz E, Rockhill B, Dart H, Hunter DJ. Harvard Report on Cancer Prevention. Volume 3: Prevention of colon cancer in the United States. Cancer Causes and Control 1999;10:167-80.

Ueland PM, Refsum H, Beresford SAA, Vollset SE. The controversy over homocysteine and cardiovascular risk. Am J Clin Nutr 2000;72:324-32.

Verhaar MC, Wever RMF, Kastelein JJP, van Dam T, Koomans HA, Rabelink TJ. 5Methyltetrahydrofolate, the active form of folic acid, restores endothelial function in familial hypercholesterolemia. Circlation 1998;97:237-41.

Vitamin Study Research Group. Prevention of neural tube defects: Results of the Medical Research Council Vitamin Study. The Lancet 1991;338:131-7.

Voedingsraad. Nederlandse Voedingsnormen 1989. Advies opgesteld door de Commissie Voedingsnormen, Den Haag 13 juli 1989. Voorlichtingsbureau voor de Voeding. 's-Gravenhage 1989.

White E, Shannon JS, Patterson, RE. Relationship between vitamin and calcium supplement use and colon cancer. Cancer Epidemiol. Biomarkers Prev 1997:6:769-74.

Zo eet Nederland. Resultaten van de Voedselconsumptiepeiling 1997-1998. Voedingscentrum, Den Haag 1998. 


\section{Summary}

Folic acid does not occur naturally in foods in significant amounts. It is the common, most stable, synthetic form used in supplements or food fortification. Natural folates comprise an extended family of mono- and polyglutamates of pteroic acid, which qualitatively exhibit the biological activity of folic acid. The pteridine ring is reduced to give the 7,8-dihydrofolate and subsequently $5,6,7,8$ tetrahydrofolate. These reduced forms can be substituted with a covalently bonded one-carbon adduct attached to the nitrogen positions 5 or 10 , or bridged across these two positions. Besides tetrahydrofolate, the most substituted forms in the human diet are: 5 -formyl, 10-formyl, 5-methyl. Other frequently occurring folates are 10 -formyldihydrofolate and 10 -formylfolic acid. Approximately $80 \%$ of all food folates exist as polyglutamates, which need to be cleaved into folate monoglutamates by pteroylpolyglutamate hydrolase (conjugase), present in the intestinal brush border, before they can be absorbed in the intestine. Certain factors in food, like dietary fiber and certain organic acids in for example orange juice, may inhibit the deconjugation of polyglutamates.

There are a number of important processes in which folates play a significant role in human health (Chapter 1 ). The folate-mediated transfer of one-carbon units from serine provides a major source of substrate in the one-carbon metabolism. Folate coenzymes play a role in the synthesis of thimidylate and purines, which are building blocks for RNA and DNA. The conversion of homocysteine to methionine, involves both a vitamin $B_{12}$ coenzyme and 5-methyltetrahydrofolate as substrates.

The RDA for folate in the Netherlands is currently $200-300 \mu \mathrm{g} / \mathrm{d}$ for adults, $40-60$ $\mu \mathrm{g} / \mathrm{d}$ for children, and $400 \mu \mathrm{g}$ folic acid per day for pregnant women or women capable of becoming pregnant.

A number of diseases are associated with folate metabolism. Folic acid plays a role in the prevention of neural tube defects. It was estimated that adequate intake of folic acid $(400 \mu \mathrm{g} / \mathrm{day})$ by women capable of becoming pregnant would reduce the prevalence of neural tube defects in The Netherlands with about $60 \%$. Several studies have shown that cardiovascular disease risk is associated with high levels of plasma homocysteine. Increased intake of folic acid as well as food folates was found to decrease the plasma homocysteine level. Cancer of the colon and the rectum is the fourth most common incident cancer and cause of death from cancer throughout the world. An estimated 875,000 cases occurred in 1996, accounting for $8.5 \%$ of all new cases of cancer. Incidence of and death rates from this cancer are generally increasing, most of all in the developed world and in urban areas of the developing world. Colorectal cancer is thought to be modified mainly by food and nutrition (World Cancer Research Fund/American Institute for Cancer 
Research 1997). The following mechanisms may play a role in these processes. Folate deficiency causes massive incorporation of uracil into human DNA, which may result in the initiation of neoplastic transformation. In addition reduced methylation of DNA has been observed in human colorectal cancer, possibly due to a low folate intake. A mutation in the methylenetetrahydrofolate reductase (MTHFR) gene in combination with folate intake may also play a positive or negative role regarding colorectal cancer.

When dietary folate intake is assessed, which is needed to study associations with diseases, a number of problems are encountered. Firstly, no up-to-date folate data were available in the Dutch food composition table. Secondly, differences in analytical methods and sample preparation are thought to be the most crucial factors impeding an accurate determination of dietary folate intake when data of foreign food consumption tables are used. This thesis addresses a number of these emerging issues, before finally investigating the association between dietary folate intake and colorectal cancer risk.

The microbiological methods commonly used for folate analysis can only quantify total folate. Certain non-folate compounds may either stimulate or inhibit bacterial growth, resulting in unreliable data. Above all, the apparent reduced bioavailability of polyglutamates compared to monoglutamates, as well as the possible difference in bioavailability of different folate vitamers, indicate the need for a validated method for the analysis of individual folate vitamers in foods, so that associations with diseases can be studied as accurate as possible.

For the determination of folates in foods in this study a liquid chromatographic (HPLC) method was elaborated (Chapter 2). Folates were extracted by homogenizing in buffer and heat treatment. A portion was incubated with an enzyme preparation. After purification by affinity chromatography, folate monoglutamates were determined by reversed-phase LC with fluorescence and diode array detection. The most abundant folate forms naturally present in foods were detected, including tetrahydrofolic acid, 5-methyltetrahydrofolic acid, and 5formyltetrahydrofolic acid. 10-Formylfolic acid could be detected by applying a second fluorescence detector. Folic acid, used for fortification, might also be quantified with this system. The difference between folate concentrations in sample extracts, with and without treatment of conjugase, is a measure of the quantity of polyglutamates in the food matrixes. An additional treatment with conjugase, amylase, and protease reflects the amount of matrix-bound folates. Repeatability relative standard deviation values for separate folates in 4 Certified Reference Materials (CRMs): mixed vegetables (CRM 485), pig liver (CRM 487), whole-meal flour (CRM 121) and milk powder (CRM 421) varied from 3.3 to $21.0 \%$ for the concentration range $1.8-1440 \mu \mathrm{g} / 100 \mathrm{~g}$. Recoveries ranged from $73-109 \%$. Use of 
amylase and protease was advantageous. Use of a commercially available folatebinding protein for cleanup saved time and money and was effective. Results for 5methyltetrahydrofolic acid were in good agreement with results obtained with other LC methods. Results for total folates were lower than results obtained with microbiological methods.

The purposes of the second study (Chapter 3) were first to analyze 125 of the most important foods that contribute to folate intake in the Netherlands and second to estimate the folate intake of a representative sample of the Dutch population. The folate content of particularly vegetables, fruit, potatoes, bread, milk and milk products, and meat and meat products were analyzed by using the newly developed HPLC trienzyme method combined with an affinity chromatography cleanup step. These results were then used to estimate the folate intake of persons aged 1-92 who participated in the second Dutch National Food Consumption Survey (DNFCS) in $1992(n=6218)$. The newly compiled data comply with specific quality criteria for analytical methods, analytical quality control, sample handling and sampling plan, to produce high quality food folate composition data. Total folate amounts in foods analyzed by HPLC were approximately $25 \%$ lower than amounts listed in recent food composition tables estimated by use of the microbiological method. However, this was not statistically significant for all tables. The most important folate vitamer in all food categories was 5methyltetrahydrofolate $(62 \%)$. Tetrahydrofolate was present in liver and liver products in significant amounts $(40 \%)$. Off all vitamers $71 \%$ was present as polyglutamates. The mean dietary folate intake of the DNFCS according to the current food composition tables, based on microbiological food folate data, was $251 \pm 97 \mu \mathrm{g} / \mathrm{d}$. The mean dietary folate intake, based on the new HPLC data was $182 \pm 119 \mu \mathrm{g} / \mathrm{d}$. The mean daily dietary folate intake for participants aged $\geq 16 \mathrm{y}$ was $193 \pm 112 \mu \mathrm{g} / \mathrm{d}\left(\mathrm{n}=4777,95^{\text {th }}\right.$ percentile: $319 \mu \mathrm{g} / \mathrm{d}$; men: $215 \pm 120 \mu \mathrm{g} / \mathrm{d}$; women: $173 \pm 100 \mu \mathrm{g} / \mathrm{d})$. The mean dietary folate intake for participants < 16y was $130 \pm 64 \mu \mathrm{g} / \mathrm{d}(\mathrm{n}=1419)$, whereas the intake for pregnant women was $187 \pm 62$ $\mu \mathrm{g} / \mathrm{d}(\mathrm{n}=58$ ). Nobody used folic acid containing supplements. Total intake of supplement users $(n=86)$ was $344 \mu \mathrm{g} / \mathrm{d}$, with $147 \mu \mathrm{g} / \mathrm{d}$ originating from supplements. On the basis of these findings $42 \%$ of men and $54 \%$ of women do not meet current Dutch recommendations of $60 \mu \mathrm{g} / \mathrm{d}$ for children and $200 \mu \mathrm{g} / \mathrm{d}$ for adults. However, $4 \%$ of adult men and $11 \%$ of adult women consumed less than the minimum requirement of $100 \mu \mathrm{g} / \mathrm{d}$. The current recommended intake of $200 \mathrm{~g}$ vegetables and 2 pieces of fruit a day should ensure a folate intake of more tan $100 \mu \mathrm{g} / \mathrm{d}$ for everyone. Many foods with high folate contents, such as broad beans, spinach, Brussels sprouts, and broccoli do not rank high in actual dietary folate intake because of their low consumption rate. Furthermore, based on analytical results strawberries, leek, cauliflower, asparagus, kale, endive, kiwi and orange are 
rich sources of folate. Increased consumption of these products could be recommended to enhance folate intake.

The study described in chapter 4 was designed to determine the bioavailability of the different natural folates in healthy ileostomy volunteers $(N=11)$. Up till now the bioavailability of food folate in relation to folic acid is supposed to be $50 \%$. Our understanding of possible causes for this poor bioavailability is incomplete. Factors that might affect folate availability are: intestinal deconjugation, intestinal stability, drugs, and food containing brush border conjugase inhibitors. In this study a singledose short-term protocol was used. The most important issues concern the deconjugation process as a possible limiting factor in the absorption of folates. The use of ileostomy volunteers gave us the possibility to validate the use of the area under the serum response curve (AUC) from food compared to folic acid as a proxy variable for food folate bioavailability. In this study spinach was selected as food matrix based on the fact that total folate concentration is high, it is an excellent source of various folate vitamers, and in vitro experiments have indicated that spinach components inhibit human conjugase. Based on analysis of test meals and ileostomy effluents, there was no difference in folate absorption between spinach with a mono-/polyglutamate ratio of $40: 60$ and the same spinach with a 100:0 ratio. Vitamers present in cooked spinach were 5-methyltetrahydrofolate, $10-$ formyldihydrofolate and 10-formylfolic acid. In contrast the general accepted level of $50 \%$ absorption based on one study, the actual absorption levels were $89 \%$, $88 \%$ and $74 \%$ respectively. Supplemental folic acid was absorbed for $91 \%$.

The results from this study revealed that the bioavailability of spinach folate is approximately $90 \%$ of that of synthetic folic acid. Recently, another study showed that the bioavailability of folate from vegetables and citrus fruits was higher than $50 \%$ relative to folic acid. We found $25-30 \%$ lower total folate values compared to levels listed in the current food composition tables. If intake levels of food folate are assumed to be $25-30 \%$ higher in the up to now described studies, the bioavailability relative to folic acid decreases by the same percentage. Based on these data, it can be concluded that the bioavailability of food folate is higher than $50 \%$.

After consumption of the spinach meals and the folic acid supplements, comparable AUCs were found. According the amount of folic acid/folates absorbed, the AUC from the supplement was expected to be approximately $45 \%$ higher than the AUCs from spinach. This suggests a metabolic difference between uptake and clearance of dietary folates and synthetic folic acid. This suggestion is supported by the fact that unmetabolized folic acid was found in the serum. Results from this study revealed that the absolute bioavailability of spinach folate $(78 \%)$ calculated from the difference between folate intake and folate content of ileostomy effluents was not equal to the relative bioavailability (114\%), calculated from AUCs 
after consumption of spinach meals in relation to AUCs after consumption of the folic acid supplement. This means that comparing AUCs of food folate versus supplemental folic acid may not be suitable for assessing relative food folate bioavailability. It would be interesting to compare the spinach AUCs with an AUC after the intake of $5-\mathrm{CH}_{3}-\mathrm{H}_{4}$ folate, the most common natural source of folate.

Several studies have reported inverse associations between folate intake and colorectal cancer risk; very few were prospective studies however, and none examined the association between the intake of individual folate vitamers and colorectal cancer risk. The aim of the fourth study (Chapter 5) was to investigate the relationship between dietary folate intake and the risk of colon and rectal cancer in a large prospective cohort study in the Netherlands among 120,852 men and women aged 55-69 $y$, named the Netherlands Cohort on diet and cancer (NLCS). This study was started in 1986. At baseline, all participants completed a questionnaire on habitual dietary intake, dietary supplement use, lifestyle characteristics, medical history and other potential risk factors for cancer. Followup for incident cancer was established by record linkage with all regional cancer registries in The Netherlands and the national pathology register. After 7.3 years of follow-up, 760 colon and 411 rectal cancer cases were available for analysis. Data processing and analysis used the case-cohort approach, which means that cases were gathered from the entire cohort, whereas the accumulated person years in the cohort and intake were estimated from a subcohort sample consisting of 3500 subjects. The new Dutch database (chapter 3) was used to estimate intakes of total and individual folates. Total folate intake for the subcohort was $224 \pm 73 \mu \mathrm{g} / \mathrm{d}$ for men and $200 \pm 65 \mu \mathrm{g} / \mathrm{d}$ for women. The most important vitamers which contributed to this intake was 5-methyltetrahydrofolate and 5-formyltetrahydrofolate for $60 \%$ and $11 \%$ respectively. Analyses adjusted for age, energy intake, family history of colorectal cancer, alcohol, vitamin $\mathrm{C}$, iron and dietary fiber intake yielded an inverse association between colon cancer risk and total dietary folate intake (RR highest vs. lowest quintile, Men: $0.73 ; 95 \% \mathrm{Cl}, 0.46-1.17, \mathrm{P}$ trend $=0.03$; Women: $0.68 ; 95 \% \mathrm{Cl}, 0.39-1.20, \mathrm{P}$ trend $=0.18$ ). An inverse association between rectal cancer and total dietary folate intake was found only among men. (RR highest vs. lowest quintile, Men: $0.66 ; 95 \% \mathrm{Cl}, 0.35-1.21, \mathrm{P}$ trend $=0.03$ ).

Analyses for individual folates revealed that the associations of 5methyltetrahydrofolate and 5-formyltetrahydrofolate corresponded best with the above associations regarding total folate intake. Results described in Chapter 5 confirm the role of a reduced folate intake as a potential risk factor of colorectal cancer. Results revealed that dietary folate was significantly inversely related to colon cancer (and to male rectal cancer). This means that the use of folate-rich vegetables and fruits may reduce the risk of colorectal cancer and not necessarily folic acid from supplements. To date, it is not allowed in the Netherlands to fortify 
foods with folic acid. For the time being, an intake of $200 \mathrm{~g}$ vegetables and 2 pieces of fruit daily is recommended to enhance intake of folate and other nutrients. This is approximately double the amount of fruit and vegetables found to be consumed in the Dutch National Food Consumption Survey (DNFCS) carried out in 1992. The current population-based fruit and vegetable intake accounts for approximately $50 \mu \mathrm{g}$ folate. To calculate a possible risk reduction resulting from an additional folate intake of $50 \mu \mathrm{g} / \mathrm{d}$, corresponding to the current recommendations of the Dutch Health Council, the association between folate intake and colon and rectal cancer risk was calculated per increment of $50 \mu \mathrm{g}$. The associations found in the present study suggest that an increase in folate intake of $50 \mu \mathrm{g} / \mathrm{d}$ might results in an approximately $10 \%$ reduction of the risk of colorectal cancer.

Our results, indicating a protective role of dietary folate, were confirmed by several other studies, mostly case-control studies. In these studies, dietary folate intake seemed to be inversely related to colorectal cancer, with a $35-40 \%$ risk reduction in those with the highest folate intake compared with those with the lowest intake. An inverse association between folate and colon and rectal cancer in the lower half of methionine intake seemed to be limited to men, although interaction was not statistically significant. A greater benefit of folate in the lower half of methionine intake would underline the role of folate in methionine synthesis. An insufficient folate level combined with low methionine intake might result in inadequate DNA methylation, leading to a greater risk of colon cancer, as hypomethylation is regarded as one of the earliest events in colon carcinogenesis.

Although there is evidence of subsite-specific differences in colon cancer risk associated with vegetable consumption, this was not observed for folate intake, suggesting that another component in vegetables might be responsible for this effect.

A protective effect of folate and methionine against colorectal cancer may be impaired by high alcohol consumption since alcohol acts as a methyl-group antagonist. In our study it was found that men who use a low-methyl diet (low folate-low methionine and high alcohol) were almost three times as likely to develop rectal cancer as men who on a high-methyl diet. This antagonism was les pronounced for colon cancer, however.

Intervention studies are currently underway to investigate whether homocysteine lowering therapies with folic acid lead to a decrease in cardiovascular disease. There are three large, randomized, double blind, placebo-controlled multi-center folate chemoprevention trials ongoing in the USA at present. Intervention trials should anticipate the possibility of using 5-methyltetrahydrofolate, which is the most abundant folate vitamer in foods. The use of 5-methyltetrahydrofolate could also overcome the drawback of folic acid, viz. that it masks vitamin $\mathrm{B}_{12}$ deficiency. 


\section{Samenvatting}

Foliumzuur komt in voedingsmiddelen van nature niet in grote hoeveelheden voor. Het is de meest stabiele synthetische vorm die wordt toegepast bij de verrijking van levensmiddelen en voedingssupplementen. Deze vorm wordt in de Engelstalige literatuur aangeduid als "folic acid". Natuurlijk voorkomende foliumzuurverbindingen omvat een uitgebreide groep van mono- en polyglutamaten van pterinezuur, die kwalitatief gezien dezelfde biologische activiteit bezitten als foliumzuur. Deze groep wordt in de Engelstalige literatuur aangeduid als "folates". De pteridinering wordt gereduceerd naar 7,8dihydrofoliumzuur en vervolgens naar 5,6,7,8-tetrahydrofoliumzuur. Deze gereduceerde vormen kunnen gesubstitueerd zijn met een covalent gebonden koolstofverbinding aan de stikstofpositie 5 en/of 10 . Naast tetrahydrofoliumzuur, komen de volgende gesubstitueerde vormen het meest in voeding voor: 5 -formyltetrahydrofoliumzuur, 10-formyltetrahydrofoliumzuur, 5-methyltetrahydrofoliumzuur. Andere veel voorkomende foliumzuurverbindingen zijn 10-formyldihydrofoliumzuur en 10-formylfoliumzuur. Ongeveer $80 \%$ van alle foliumzuurverbindingen in de voeding komen voor als polyglutamaten die gesplitst moeten worden in foliumzuurmonoglutamaten door pteroylpolyglutamaathydrolase (conjugase), aanwezig in de darmwand, alvorens ze kunnen worden opgenomen in de dunne darm. Bepaalde componenten in levensmiddelen zoals voedingsvezel en organische zuren in bijvoorbeeld sinaasappelsap remmen mogelijk de deconjugatie van polyglutamaten.

Er zijn een aantal humaan fysiologische processen waarbij foliumzuur een rol speelt (Hoofdstuk 1). Serine wordt omgezet in één-koolstof eenheden onder invloed van foliumzuur. Deze verbindingen vormen een voorraad reactieve koolstofgroepen die bij de meest uiteenlopende processen gebruikt kunnen worden. Zo spelen deze verbindingen een rol bij de synthese van purine- en pyrimidine-verbindingen, die de basen leveren welke als bouwstenen voor DNA en RNA belangrijk zijn voor de synthese van celkernmateriaal. Bij de omzetting van homocysteïne naar methionine zijn een vitamine $B_{12}$-coenzym en 5methyltetrahydrofoliumzuur betrokken als substraat.

$\mathrm{De}$ aanbevolen dagelijkse hoeveelheid $(\mathrm{ADH})$ voor foliumzuur is in Nederland momenteel 200-300 $\mu \mathrm{g} / \mathrm{dag}$ voor volwassenen, 40-60 $\mu \mathrm{g} / \mathrm{dag}$ voor kinderen en 400 $\mu \mathrm{g}$ synthetisch foliumzuur voor zwangeren en vrouwen met een zwangerschapswens.

Een aantal aandoeningen worden geassocieerd met het foliumzuurmetabolisme. Foliumzuur speelt een belangrijke rol bij de preventie van neuraalbuis defecten 
oftewel "open ruggetje". Er wordt geschat dat bij een adequaat foliumzuurgebruik door vrouwen met een zwangerschapswens $(400 \mu \mathrm{g} / \mathrm{dag})$ de prevalentie van neuraalbuis defecten zou verminderen met ongeveer $60 \%$. Een aantal studies hebben laten zien dat het risico op hart- en vaatziekten wordt geassocieerd met hoge homocysteïne gehaltes in het bloed. Een verhoogde inname van foliumzuur, zowel als voedingsfoliumzuur of als synthetisch foliumzuur, laten een daling van dat homocysteïne gehalte in het bloed zien. Darmkanker is de vierde meest voorkomende vorm van kanker in de wereld. Ongeveer 875.000 nieuwe gevallen werden geconstateerd in 1996. Dit komt neer op 8,5\% van alle nieuwe gevallen van kanker. De incidentie en sterfte naar aanleiding van darmkanker nemen over het algemeen toe, voornamelijk in de westerse wereld en de dichtbevolkte steden van de ontwikkelingslanden. Darmkanker is een aandoening waarvan gedacht wordt dat het risico wordt verhoogd door de voeding (World Cancer Research Fund/American Institute for Cancer Research). De volgende mechanismen kunnen in dit proces een rol spelen. Een tekort aan foliumzuur zorgt voor een toegenomen inbouw van uracil in DNA, dat kan resulteren in neoplastische transformatie. Verder wordt een verminderde methylering van DNA geconstateerd bij darmkanker van de mens. Dit is mogelijk het gevolg van een tekort aan foliumzuur. Een mutatie in het methyleentetrahydrofoliumzuur-reductase (MTHFR) gen speelt mogelijk in combinatie met de foliumzuurinname een positieve en/of negatieve rol met betrekking tot darmkanker.

Het bepalen van de inname van foliumzuur via de voeding, die nodig is om de associatie met ziekte te bestuderen, is problematisch. Ten eerste zijn er geen upto-date gegevens van foliumzuur beschikbaar in de Nederlandse Voedingsmiddelentabel. Ten tweede, verschillen in analytische methoden en monstervoorbereiding van gegevens uit buitenlandse voedingsmiddelentabellen zijn de meest cruciale factoren die een nauwkeurige berekening van de foliumzuurinname verhinderen. In deze dissertatie zijn een aantal voornoemde problemen uitgewerkt alvorens de associatie tussen de inname van foliumzuur via de voeding en het risico op dikke darm- en endeldarmkanker kon worden onderzocht.

Microbiologische methoden die over het algemeen worden toegepast in de foliumzuuranalyse kunnen alleen totaal foliumzuur kwantificeren. Mogelijk kunnen andere componenten in de voeding de bacteriële groei remmen of juist stimuleren. Dit resulteert in onbetrouwbare gegevens. Bovenal, de vermeende gereduceerde biologische beschikbaarheid van foliumzuurpolyglutamaten ten opzichte van foliumzuurmonoglutamaten alsook het mogelijk verschil in biologische beschikbaarheid van de verschillende foliumzuurvitameren, tonen de behoefte aan van een gevalideerde analysemethode voor de individuele foliumzuurvitameren in 
voedingsmiddelen, zodat associates met aandoeningen zo specifiek mogelijk kunnen worden bestudeerd. Voor de analyse van foliumzuur in voedingsmiddelen werd in dit onderzoek een vloeistofchromatografische (HPLC) methode ontwikkeld (Hoofdstuk 2). Foliumzuur werd geëxtraheerd door homogenisatie en verwarmen in buffer. Een gedeelte werd geïncubeerd met een mengsel van enzymen. $\mathrm{Na}$ zuivering van de extracten met behulp van affiniteitschromatografie werden foliumzuurmonoglutamaten geanalyseerd met reversed-phase chromatografie met fluorescentie en diode-array detectie. De meest voorkomende foliumzuurverbindingen in de voeding werden bepaald: tetrahydrofoliumzuur, 5methyltetrahydrofoliumzuur en 5-formyltetrahydrofoliumzuur. 10-Formylfoliumzuur werd gedetecteerd met een tweede fluorescentiedetector. Synthetisch foliumzuur kon ook gekwantificeerd worden met dit systeem. Het verschil in foliumzuurconcentratie in de monsterextracten die wel en niet geïncubeerd werden met conjugase, was een maat voor de hoeveelheid foliumzuurpolyglutamaat in de voedingsmatrix. Een aanvullende behandeling met conjugase, amylase en protease gaf de hoeveelheid matrix-gebonden foliumzuur weer. De herhaalbaarheid voor de individuele foliumzuurvitameren in 4 gecertificeerde referentiematerialen (CRMs): gemengde groente (CRM 485), varkenslever (CRM 487), volkorenmeel (CRM 121) en melkpoeder (CRM 421) varieerde van 3.3 tot $21.0 \%$ voor het concentratiebereik van $1.8-1440 \mu \mathrm{g} / 100 \mathrm{~g}$. Recoveries varieerden van $73-109 \%$. Het gebruik van amylase en protease was zinvol. Gebruik van commercieel verkrijgbaar foliumzuur-bindend-eiwit voor de zuivering van extracten spaarde tijd, geld en was tevens effectief. Resultaten voor 5methyltetrahydrofoliumzuur kwamen goed overeen met waarden die gevonden waren in andere vloeistofchromatografische onderzoeken. Resultaten voor totaal foliumzuur met behulp van vloeistofchromatografie waren over het algemeen lager dan de gehaltes die gekwantificeerd zijn door microbiologische analysemethodes.

Het doel van de tweede studie (Hoofdstuk 3) was ten eerste: de analyse van de 125 meest belangrijke voedingsmiddelen die een bijdrage leveren aan de foliumzuurinname in Nederland en ten tweede: het schatten van de foliumzuurinname voor een representatieve steekproef van de Nederlandse bevolking. De foliumzuurgehaltes in met name groente, fruit, aardappelen, brood, melk - en melkproducten en vlees- en vleesproducten werden geanalyseerd aan de hand van de nieuw ontwikkelde HPLC-methode. Deze resultaten zijn vervolgens gebruikt om de foliumzuurinname te schatten van personen in de leeftijd van 1-92 jaar die deelnamen aan de tweede Nederlandse Voedselconsumptiepeiling (VCP) in $1992(n=6218)$. De nieuw geanalyseerde gehaltes voor voedingsfoliumzuur kwamen overeen met specifieke kwaliteitscriteria gesteld voor analytische methodes, analytische kwaliteitscontrole, monsterbehandeling en monsterplan. De totale hoeveelheid foliumzuur, 
geanalyseerd aan de hand van HPLC, was ongeveer $25 \%$ lager dan de hoeveelheden in de huidige voedingsmiddelentabellen, die vastgesteld zijn aan de hand van microbiologische analysemethodes. Dit resultaat was echter niet significant voor alle voedingsmiddelentabellen. De belangrijkste vitameer die in alle categorieën van producten voorkwam is 5-methyltetrhydrofoliumzuur (62\%). Verder kwam tetrahydrofoliumzuur in aanzienlijke hoeveelheden voor in met name in lever- en leverproducten (40\%). Van alle vitameren kwam $71 \%$ voor als polyglutamaat. De gemiddelde voedingsfoliumzuurinname, voor deelnemers aan de VCP, op basis van de huidige voedingsmiddelentabellen met microbiologische analysegegevens was $251 \pm 97 \mu \mathrm{g} / \mathrm{dag}$. De gemiddelde voedingsfoliumzuurinname op basis van de nieuwe HPLC gegevens was $182 \pm 119 \mu \mathrm{g} / \mathrm{dag}$. Voor de leeftijd $\geq 16$ jaar was de inname gemiddeld $193 \pm 112 \mu \mathrm{g} / \mathrm{dag}\left(n=4777,95^{\text {ste }}\right.$ percentiel: $319 \mu \mathrm{g} / \mathrm{dag} ;$ mannen: $215 \pm 120 \mu \mathrm{g} / \mathrm{dag}$; vrouwen: $173 \pm 100 \mu \mathrm{g} / \mathrm{dag}$ ). De gemiddelde voedingsfoliumzuurinname voor personen $<16$ jaar was $130 \pm 64 \mu \mathrm{g} /$ dag ( $n=1419)$. De gemiddelde voedingsfoliumzuurinname voor zwangeren was 187 $\pm 62 \mu \mathrm{g} / \mathrm{dag}(\mathrm{n}=58)$. Niemand van hen gebruikte supplementen met foliumzuur. Dagelijkse foliumzuurinname voor supplementgebruikers $(n=86)$ was $344 \mu \mathrm{g}$, waarvan $147 \mu \mathrm{g}$ afkomstig was van supplementen. Op basis van deze gegevens voldoen $42 \%$ van de mannen en $54 \%$ van de vrouwen niet aan de Nederlandse aanbevelingen van $60 \mu \mathrm{g} / \mathrm{dag}$ voor kinderen en $200 \mu \mathrm{g} / \mathrm{dag}$ voor volwassenen. Echter, $4 \%$ van de volwassen mannen en $11 \%$ van de volwassen vrouwen hadden een inname die lager was de minimum behoefte van $100 \mu \mathrm{g} / \mathrm{dag}$. De huidige aanbeveling van 200 gram groente en 2 stuks fruit zal een minimale inname van $100 \mu \mathrm{g} / \mathrm{dag}$ voor iedereen zeker stellen. Een aantal voedingsmiddelen die rijk zijn aan foliumzuur, zoals tuinbonen, spinazie, spruitjes en broccoli, scoren niet hoog in de bijdrage aan de foliumzuurinname omdat ze weinig gegeten werden. Verder is naar aanleiding van de analyseresultaten gebleken dat aardbeien, prei, bloemkool, asperges, boerenkool, andijvie, kiwi en sinaasappel rijke bronnen van foliumzuur zijn. Een verhoogd gebruik van dergelijke producten zou aanbevolen moeten worden om de foliumzuurinname te verhogen.

De studie die in hoofdstuk 4 is beschreven, was opgezet om de biologische beschikbaarheid van verschillende foliumzuurvitameren nader te onderzoeken bij gezonde vrijwilligers $(n=11)$ met een ileostoma. Tot op heden wordt verondersteld dat de biologische beschikbaarheid van voedingsfoliumzuur $50 \%$ is ten opzichte van synthetisch foliumzuur. Kennis over de mogelijke oorzaken van die gereduceerde biologische beschikbaarheid is niet compleet. Factoren die mogelijk de biologische beschikbaarheid van foliumzuur uit voeding beïnvloeden zijn: deconjugatie in de dunne darm, stabiliteit in de darm, geneesmiddelen en conjugaseremmers uit voedingsmiddelen. 
In deze studie is gebruik gemaakt van een enkele dosering korte termijn protocol. De belangrijkste kwesties die onderzocht zijn hebben te maken het deconjugatieproces als mogelijk limiterende factor in de absorptie van foliumzuur uit spinazie. Door gebruik te maken van proefpersonen met een ileostoma gaf de studie de gelegenheid om het gebruik van het oppervlak onder de serumresponscurve (AUC) van voedingsfoliumzuur ten opzichte van synthetisch foliumzuur te valideren als maat voor de biologische beschikbaarheid van voedingsfoliumzuur. Spinazie werd uitgekozen als voedingsmatrix omdat het foliumzuurgehalte hoog was en uit resultaten van in vitro studies bleek dat door componenten uit spinazie de activiteit van humaan conjugase geremd werd. Op basis van de analyse van testmaaltijden en stomavloeistoffen kon worden geconcludeerd dat er geen verschil was in de absorptie van foliumzuur uit spinazie met een mono-/polyglutamaat ratio van 40:60 en een vergelijkbare spinazie met een ratio van 100:0. De verschillende foliumzuurvitameren in spinazie zijn 5methyltetrahydrofoliumzuur, 10-formyldihydrofoliumzuur en 10-formylfoliumzuur. In tegestelling tot de in het algemeen geaccepteerde voedingsfoliumzuurabsorptie van $50 \%$ was de absorptie van deze afzonderlijke verbindingen respectievelijk $89 \%, 88 \%$ en $74 \%$. Foliumzuur uit een supplement werd voor $91 \%$ geabsorbeerd.

De resultaten van deze studie lieten zien dat de biologische beschikbaarheid van foliumzuur in spinazie ongeveer $90 \%$ was ten opzichte van synthetisch foliumzuur. Recent liet een andere studie zien dat de biologische beschikbaarheid van foliumzuur uit groente en citrusfruit $>50 \%$ was ten opzichte van synthetisch foliumzuur. In ons onderzoek waren $25-30 \%$ lagere waardes gevonden voor het totaal foliumzuurgehalte in voedingsmiddelen als deze werden vergeleken met waardes uit bestaande voedingsmiddelentabellen. Als in de tot nu toe beschreven biologische beschikbaarheidstudies verondersteld wordt dat de innames van voedingsfoliumzuur $25-30 \%$ hoger zijn, op basis van gegevens in de bestaande voedingsmiddelentabellen, dan daalt de veronderstelde relatieve biologische beschikbaarheid ten opzichte van synthetisch foliumzuur met $25-30 \%$. Op basis van deze gegevens kan geconcludeerd worden dat de biologische beschikbaarheid van voedingsfoliumzuur hoger is dan de tot nu toe veronderstelde $50 \%$.

$\mathrm{Na}$ consumptie van spinazie en de foliumzuursupplementen werden vergelijkbare AUCs gevonden. Op basis van de geabsorbeerde hoeveelheden foliumzuur uit spinazie en synthetisch foliumzuur werd verwacht dat de AUC na inname van het foliumzuursupplement ongeveer $45 \%$ hoger zou moeten zijn dan de AUCs na de consumptie van spinazie. Dit suggereert een metabolisch verschil tussen de opname en klaring van voedingsfoliumzuur en synthetisch foliumzuur. Deze suggestie werd ondersteund door het feit dat er ongemetaboliseerd foliumzuur wordt aangetroffen in serum. Resultaten van deze studie lieten zien dat de absolute biologische beschikbaarheid van spinaziefoliumzuur $(78 \%)$, berekend 
uit het verschil tussen foliumzuurinname en foliumzuurgehalte in de stomavloeistoffen niet gelijk was aan de relatieve biologische beschikbaarheid $(114 \%)$, berekend op basis van de AUCs na consumptie van spinazie ten opzichte van de AUCs na inname van het foliumzuursupplement. Dit betekent dat vergelijking van AUCs van voedingsfoliumzuur versus synthetisch foliumzuur niet geschikt is voor de bepaling van de relatieve biologische beschikbaarheid. Het zou interessant zijn om de AUCs na de consumptie van spinazie te vergelijken met een AUC na de inname van 5-methyltetrahydrofoliumzuur, de meest van nature voorkomende vitameer.

Verschillende studies hebben inverse associaties aangetoond tussen foliumzuurinname en het risico op darmkanker. Echter, zeer weinig studies hadden een prospectief karakter en geen studie onderzocht de associatie tussen de inname van individuele foliumzuurvitameren en het risico op darmkanker. Het doel van de vierde studie (Hoofdstuk 5) was om de relatie te onderzoeken tussen de inname van foliumzuur via de voeding en het risico op darmkanker. Daarbij werd onderscheid gemaakt in dikke darm- en endeldarmkanker. Deze studie werd uitgevoerd aan de hand van een grote Nederlandse prospectieve cohortstudie onder 120.852 mannen en vrouwen in de leeftijd van 55-69 jaar, genoemd de Nederlandse Cohortstudie naar voeding en kanker (NLCS). Deze studie is gestart in 1986. Aan de hand van een voedselfrequentielijst werden voedingsgewoonten van een jaar voor de start van de NLCS vastgelegd. Er werd ook gevraagd naar het gebruik van voedingssupplementen, leefstijl, medische geschiedenis en andere potentiële risicofactoren voor kanker. Door koppeling van NLCS-gegevens met de kankerregistratie en het pathologieregister werden er na 7,3 jaar follow-up 760 gevallen van dikke darmkanker geconstateerd en 411 gevallen van endeldarmkanker. Gegevensverwerking en analyse heeft plaatsgevonden aan de hand van de zogenaamde 'patiënt-cohort' benadering. Dit betekent dat patiënten werden verzameld uit het gehele cohort en gegevens als inname en opgebouwde persoonsjaren geschat werden aan de hand van een subcohort van 3500 personen. De nieuwe voedingsmiddelentabel met foliumzuurgegevens uit hoofdstuk 3 was gebruikt om de inname van totaal en individuele foliumzuurvitameren vast te stellen. De inname voor totaal foliumzuur in het subcohort was voor mannen $224 \pm 73 \mu \mathrm{g} / \mathrm{dag}$ en voor vrouwen $200 \pm 65 \mu \mathrm{g} / \mathrm{dag}$. De belangrijkste vitameren die deel uit maakten van die inname waren 5methyltetrahydrofoliumzuur en 5-formyltetrahydrofoliumzuur voor respektievelijk 60 en $11 \%$. Na statistische correctie voor leeftijd, energie inname, darmkanker in de familie, alcohol consumptie en de inname van vitamine $C$, ijzer en voedingsvezel werd er een inverse associatie vastgesteld tussen het risico op dikke darmkanker en de inname van totaal foliumzuur (RR hoogste vs. laagste kwintiel, Mannen: 0,$73 ; 95 \% \mathrm{Cl}, 0,46-1,17, \mathrm{P}$ trend $=0,03$; Vrouwen: 0,$68 ; 95 \% \mathrm{Cl}, 0,39-1,20, \mathrm{P}$ trend 
$=0,18)$. Een inverse associatie tussen endeldarmkanker en totaal foliumzuurinname werd alleen berekend voor mannen (RR hoogste vs. laagste kwintiel: 0,66; 95\% Cl, 0,35-1,21, P trend $=0,03$ ).

Analyse voor de individuele foliumzuurvitameren liet zien dat de associaties van 5-methyltetrahydrofoliumzuur en 5-formyltetrahydrofoliumzuur het best overeenkwamen met de bovengenoemde associaties voor totaal foliumzuur. De resultaten die beschreven zijn in hoofdstuk 5 bevestigen de rol van een lage foliumzuurinname als een potentiële risicofactor voor darmkanker. Het gebruik van foliumzuurrijke groente en fruit kan mogelijk het risico op het krijgen van darmkanker verlagen, en niet persé foliumzuur uit supplementen.

Tot nu toe is het niet toegestaan in Nederland om voedingsmiddelen te verrijken met foliumzuur. Voorlopig wordt een inname van 200 gram groente en 2 stuks fruit aanbevolen om de inname van foliumzuur, maar ook van andere nutriënten te verhogen. Dit is ongeveer het dubbele van de hoeveelheid die in feite geconsumeerd werd tijdens de tweede Nederlandse Voedselconsumptiepeiling in 1992. Die geconsumeerde hoeveelheid groente en fruit is goed voor een foliumzuurinname van ongeveer $50 \mathrm{\mu g}$ per dag. Om een mogelijke risicovermindering te berekenen als gevolg van een extra portie groente en fruit, zoals geadviseerd wordt door de Nederlandse Gezondheidsraad, werd de associatie tussen de foliumzuurinname en het risico op dikke darm- en endeldarmkanker berekend per increment van $50 \mu \mathrm{g}$. De berekeningen in deze studie suggereren dat een toename in foliumzuurinname van $50 \mu \mathrm{g}$ per dag via de voeding mogelijk resulteert in een afname van het risico op darmkanker met ongeveer $10 \%$.

De resultaten van onze studie, die een beschermende rol aantonen voor voedingsfoliumzuur, worden bevestigd door verschillende andere studies, voornamelijk patiënt-controle onderzoeken. In die studies wordt meestal een inverse relatie gevonden tussen de inname van voedingsfoliumzuur en het risico op darmkanker, met een $35-40 \%$ daling van het risico bij personen met de hoogste foliumzuurinname ten opzichte van personen met de laagste foliumzuurinname.

Een hogere beschermende werking van foliumzuur bij de laagste methionine innames zou de rol van foliumzuur in de methioninesynthese onderstrepen. Een te lage foliumzuurinname gecombineerd met een lage methionine inname, zou kunnen resulteren in een verminderde DNA-methylering, dat op zich kan leiden tot een hoger risico op het krijgen van dikke darmkanker omdat hypomethylering gezien wordt als een van de eerste ontwikkelingen in dikke darm carcinogenese. Een inverse associatie tussen de foliumzuurinname en dikke darm- en endeldarmkanker bij de laagste inname van methionine leek in onze studie alleen voor te komen bij mannen, alhoewel de interactie statistisch niet significant was.

Alhoewel er in andere studies werd aangetoond dat er sublocalisatiespecifieke (proximale en distale dikke darm) verschillen zijn van het risico op dikke 
darmkanker geassocieerd met groenteconsumptie, werd dit niet gevonden voor foliumzuur in onze studie. Dit suggereert dat een andere component in groente verantwoordelijk is voor dit effect.

Een beschermend effect van foliumzuur en methionine bij het ontstaan van darmkanker zou verstoord kunnen worden door hoge alcoholconsumptie, omdat alcohol zich gedraagt als een methylgroep antagonist. In onze studie werd aangetoond dat mannen met een laag-methylgroephoudende voeding (lage foliumzuurinname, lage methionine-inname en hoge alcoholconsumptie) een bijna drie maal zo groot risico hadden om endeldarmkanker te krijgen dan mannen met een hoog-methylgroephoudende voeding (hoge foliumzuurinname, hoge methionine-inname en een lage alcoholconsumptie). Dit antagonisme kwam minder tot uitdrukking bij dikke darmkanker.

Op dit moment zijn interventiestudies gaande die onderzoeken of homocysteïine verlagende therapieën door foliumzuur leiden tot een daling van het aantal harten vaatziekten. Er lopen tevens drie grote gerandomiseerde, dubbel blinde, placebo-gecontroleerde multicenter foliumzuur chemopreventie-onderzoeken in de Verenigde Staten. Mede op basis van onze studies is het aan te bevelen dat in interventiestudies eerder gebruik zou moeten worden gemaakt van 5methyltetrahydrofoliumzuur, de meest van nature voorkomende vorm van foliumzuur. Het gebruik van deze vorm kan het nadelig effect van synthetisch foliumzuur, namelijk het maskeren van een vitamine $B_{12}$-deficiëntie, voorkomen. 


\section{Dankwoord}

Dit dankwoord schrijf ik als ik onderweg ben naar New Orleans om een van de resultaten uit het onderzoek, waaraan ik vier jaar werkte, te presenteren op een congres van de American Association for Cancer Research. Deze reis had ik niet kunnen ondernemen, en evenmin uiteindelijk het gehele onderzoek kunnen voltooien, zonder de medewerking, stimulans, steun en vertrouwen van vele mensen.

Op de eerste plaats wil ik Martin Wolfs hartelijk danken. Ik herinner me nog goed die middag in 1995, toen ik even met $u$ wilde praten over een cursus die ik graag wilde volgen. Dit gesprek heeft uiteindelijk geleid tot deze dissertatie. Dank voor de kans en mogelijkheden die ik van u heb gekregen om hieraan te werken.

Harry Roomans, dank voor de stimulans die ik altijd van jou heb ervaren, sinds mijn aanstelling bij de Keuringsdienst van Waren in 1984, om te blijven studeren, op de hoogte te blijven van en op zoek te gaan naar ontwikkelingen op het terrein van voeding en analyse. Een belangrijke stimulans binnen het onderzoek was jouw geloof in het gebruik van affiniteitschromatografie in de analysemethode van foliumzuur.

Theo Appelhof en Paul Beljaars, hartelijk dank voor het feit, dat jullie mij, ook na de reorganisatie van de Keuringsdienst, de mogelijkheden hebben gegeven alles tot een goed einde te brengen. Paul, dank dat jij me de beginselen van het schrijven hebt bijgebracht en dat ik daarvoor altijd bij jou terechtkon.

Wim Saris en Piet van den Brandt, dank dat jullie het aandurfden mij in het gehele tracé van onderzoeksplan tot dissertatie te begeleiden. Dank voor al jullie waardevolle opmerkingen. Wim, jij verstaat de kunst om op een humoristische wijze de druk op de ketel te houden. Jouw geloof en vertrouwen in de kwaliteit van de onderzoeken hielpen mij over een aantal teleurstellingen heen. Ook waardeer ik ten zeerste, dat je tijd vrijmaakte voor mijn humane studie, zelfs toen ik moest uitwijken naar Rotterdam.

Piet, naar aanleiding van een artikel van jou over de Nederlandse Cohort Studie naar voeding en kanker (NLCS) werd mijn interesse gewekt in de relatie voeding en kanker. Ongelooflijk, dat de ideeën van een paar jaar geleden, mede door jouw inspanningen, hebben geleid tot onderliggende resultaten.

Bij de ontwikkeling van de analysemethode ben ik dank verschuldigd voor bijdragen uit een Europese werkgroep (Standards, Measurement and Testing Program 1989-1998), waaraan met name Lissa Vahteristo uit Finland deelnam. Lissa, thanks for the discussions we had at the time I started with the analytical methodology. With your help I had a fast start with folates and HPLC.

Christianne Florisson, af en toe leek het een onbegonnen zaak om die honderden producten te verzamelen, koken, bakken, homogeniseren en 
analyseren. Dankzij jouw inzet, nauwkeurigheid en vooral humor is dit prima gelukt. Hartelijk dank hiervoor. Elisabeth Dorant, bedankt voor jou waardevolle opmerkingen bij de structurering van Hoofdstuk 3.

Dank ben ik verschuldigd aan Freddy Troost en Jacqueline Castenmiller. Jullie hebben mij ingewijd in de wereld van de humane studies. Dit onderdeel heeft me de meeste energie gekost, maar was daarom zeker niet minder boeiend. Dank aan alle medewerkers van Humane Biologie: Marco Mensink, Luc van Loon, Chris Hukshorn, Johan Senden en Joost Oomen. Ik heb veel respect voor de wijze waarop 12 vrijwilligers zich hebben ingezet om dit onderzoek tot een goed einde te brengen. Leuke herinneringen bewaar ik uit de periode dat ik een gedeelte van het onderzoek heb uitgevoerd bij Unilever. Geertrui Pieters, als het uitvoeren van humane studies mijn dagelijkse job was, zou ik $u$ zonder twijfel engageren als begeleidster van de vrijwilligers. Dankzij $u$ werd een naar verwachting lange saaie dag een aangenaam verblijf voor iedereen, dank $u$ wel. Cor Blonk, Caroline van Tuijl, Ben de Boer, Karin van het Hof en Lilian Tijburg van Unilever, dank voor jullie medewerking. Howard Franssen, sorry dat ik voor jou de vieze klusjes van het spinazie-onderzoek heb overgelaten. Jammer dat je niet bij de verdediging van deze dissertatie aanwezig kunt zijn. Dank voor je collegialiteit en inzet bij het uitvoeren van de analyses.

Toen ik startte met het epidemiologisch onderzoek was mijn eerste gedachte: "waar ben ik aan begonnen". Dankzij inspanningen van Sacha van den Crommert, Maurice Zeegers en Miranda Dirx kreeg ik langzaam maar zeker vaste grond onder de voeten. Mijn kamergenoten Daniëlle Mohren en Nicole Jansen zorgden voor een aangenaam verblijf op de afdeling epidemiologie.

Dank aan mijn collega's bij TNO voeding: Sandra Goldbohm, Henny Brants, Laura Voorrips en Karin Hulshof voor jullie bijdragen en opmerkingen.

Wim en Gilbert, iech stèl ' $t$ bezunder op pries tot geer bereid waort um op te trejje es mien paranimfe.

Dank aan mijn ouders die mij, vaak tegen de adviezen in, stimuleerden in datgene wat ik vanaf mijn twaalfde jaar wilde worden: onderzoeker.

Esmeralde, niet in de laatste plaats wil ik jou danken voor al die kopjes koffie die je naar "boven" hebt gebracht, voor alle boodschappen die je alleen hebt gedaan en klusjes die je voor mij hebt opgeknapt, maar ook vooral de manier waarop jij trots kon zijn op en enthousiast over de resultaten die ik behaalde. Door dit enthousiasme wist je mij over menig zwak moment heen te helpen, wat uiteindelijk heeft geleid tot dit resultaat.

Op weg naar huis en terugkijkend op het congres was het fijn te ervaren dat veel mensen belangstellend en enthousiast reageerden op de resultaten van het onderzoek. 


\section{About the author}

The author was born on 31 May 1961 in Heer, The Netherlands. After completing Secondary School in 1977, he studied secondary and higher laboratory education with majors in analytical - and clinical chemistry at the Zuidlimburgse Laboratoriumschool (ZLS) in Sittard. After graduating in 1984 he started his professional career as technician at the laboratory of the Keuringsdienst van Waren (Food Inspection Service) in Maastricht, where he was appointed in 1989 as senior analyst at the Department of Nutrition. During 1989 to 1996 he was involved with the development of analytical methods for the analysis of vitamins in food and food products. In 1996 he started his PhD study "Dietary folates in human nutrition" in collaboration with the Departments of Human Biology and Epidemiology of Maastricht University. During this study he obtained a MSc-degree in epidemiology. Since 1998 he is employed as adjunct-inspector at the Department Research \& Development of the Inspectorate for Health Protection and Veterinary Public Health in 's-Hertogenbosch. In 1997 he became a member of the Methods Committee on Food Nutrition of AOAC INTERNATIONAL and since 2000 he is participating in the activities of various vitamin working groups of the Netherlands Normalization Institute (NNI) and the European Committee for Standardization (CEN). He is married to Esmeralde Martin. 


\section{Publications}

\section{Papers}

Konings EJM, Welters HMA, Florisson $\mathrm{CHI}$. De bepaling van thiamine (vitamine $\mathrm{B}_{1}$ ) in zuigelingenvoeding, sportvoeding, vermageringsproducten en vitaminepreparaten met behulp van vloeistofchromatografie (LC). De Ware(n)Chemicus 1990;20:180-8.

Konings EJM. Estimation of vitamin $D$ in baby foods with liquid chromatography. Netherlands Milk \& Dairy Journal 1994;48:31-9.

Konings EJM, Roomans HHS, Beljaars PR. Liquid Chromatography determination of tocopherols and tocotrienols in margarine, infant foods, and vegetables. JAOAC Int 1996;79,4:902-6.

Konings EJM, Roomans HHS. Evaluation and validation of an LC method for the analyis of carotenoids in vegetables and fruit. Food Chem 1997;59,4:599-603.

Konings EJM. A validated Liquid Chromatographic Method for Determining folates in vegetables, milk powder, liver, and flour. JAOAC Int 1999;82,1: 119-127.

Konings EJM, Roomans HHS, Dorant E, Goldbohm RA, Saris WHM, van den

Brandt PA. Folate intake of the Dutch population according to newly established liquid chromatography data for foods. AJCN 2001;73:765-76.

Konings EJM, Troost FJ, Castenmiller JJM, Roomans HHS, van den Brandt PA, Saris WHM. Bioavailability of different types of folate in healthy ileostomy volunteers. Submitted for publication.

Konings EJM, Goldbohm RA, Brants HAM, Saris WHM, van den Brandt PA. Intake of dietary folate vitamers and risk of colon and rectal cancer. Results from the Netherlands Cohort Study. Submitted for publication.

Schurgers LJ, Konings EJM, Gijsbers LMG, Saris WHM, Vermeer C. Method for calculating the intestinal absorption of K-vitamins from their serum profiles: validation in healthy ileostomy volunteers. Submitted for publication.

Melse-Boonstra A, Verhoef $P$, Konings EJM, van Dusseldorp M, Matser A, Hollman $P$, Meyboom S, Kok FJ, West CE. Influence of processing on total, monoglutamate and polyglutamate folate content of leek, cauliflower, and green beans. Submitted for publication.

\section{Abstracts}

Konings EJM, Roomans HHS. Determination of carotenoids in fruits and vegetables by LC. Food Chem 1996; $57: 122$.

Konings EJM, Roomans HHS, Dorant E, Goldbohm RA, Saris WHM, van den Brandt PA. Newly established folate data for 125 foods by a validated LC 
method. Workshop on folate methodology for analytic and metabolic studies. Experimental Biology 2000.

Konings EJM, van den Brandt PA, Saris WHM, Brants HAM, Goldbohm RA. Intake of dietary folates and risk of colon and rectal cancer. Results from the Netherlands Cohort Study. Proceedings of the AACR 2001:42.

Konings EJM, Troost FJ, Castenmiller JJM, Roomans HHS, van den Brandt PA, Saris WHM. Bioavailability of different types of folate in healthy ileostomy volunteers. Abstract book Bioavailability 2001,

Melse-Boonstra A, Verhoef P, Konings EJM, van Dusseldorp M, Matser A, Hollman $P$, Meyboom S, Kok FJ, West CE. Can folate bioavailability rom vegetables be increased by processing treatments that stimulates endogenous glutamate carboxypeptidase II activity? Abstract book Bioavailability 2001.

Konings EJM, Roomans HHS, Dorant E, Goldbohm RA, Saris WHM, van den Brandt PA. Half Nederland haalt foliumzuuraanbevelingen niet. Voeding $\mathrm{Nu}$ 2001;5:35. 